. DEPARTMENT OF THE INTERIOR

UNITED STATES GEOLOGICAL SURVEY

GEORGE OTIS SMITH, DIRECTOR

BULLETIN 404

\title{
THE GRANITES OF VERMONT
}

\author{
BY \\ T. NELSON DALE
}

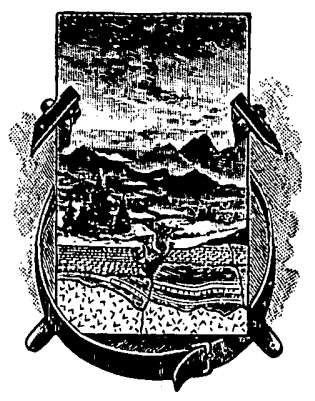

WASHINGTON

GOVERNMENT PRINTING OFFICE

1909 . 



\section{CONTENTS.}

Tringe.

PART 1. Scien'rific Discussion . .

Geographic distribution of Vermont granites.................. 9

General petrography of Vermont granites . . . . . . . . . . . . . . . 11

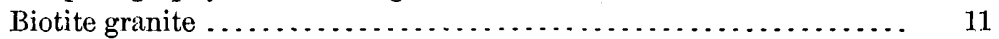

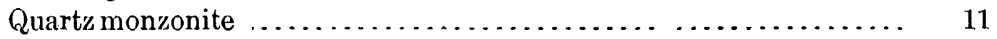

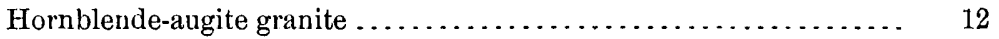

Geologic relations of Vermont granites. . . . . . . . . . . . . . . . 13

Outline of the earlier geologic history of Vermont granites. . . . . . . . 16

Important geologic features at the quarries. . . . . . . . . . . . 16

Double-sheet structure. . . . . . . . . . . . . . . . . . . . . . 17

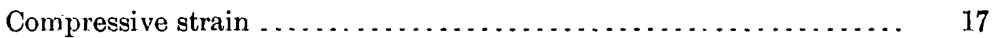

Schist inclusions. . . . . . . . . . . . . 18

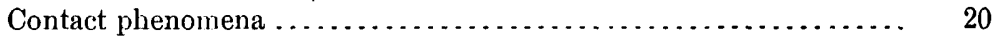

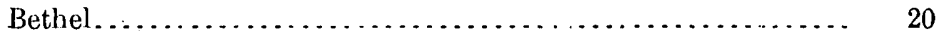

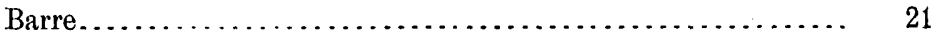

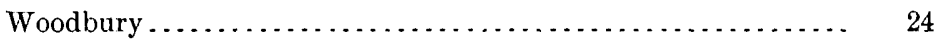

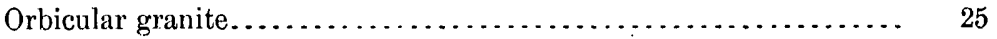

Delimonitization on the underside of sheets. ................ 26

Part II. Economic Discussion ................................ 27

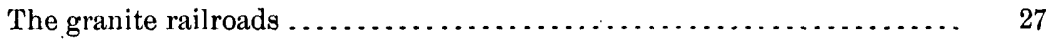

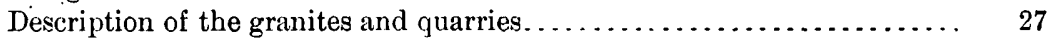

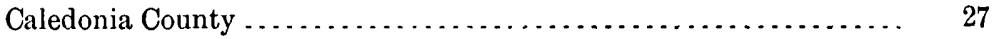

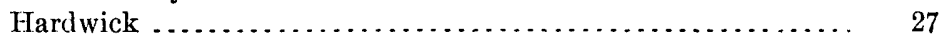

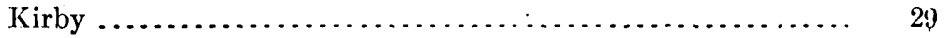

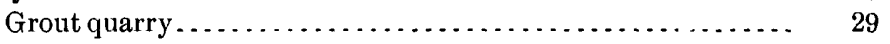

Kearney Hill quarry....................... 31

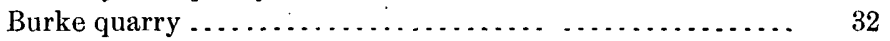

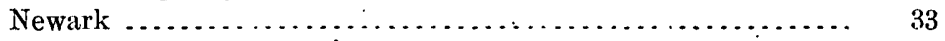

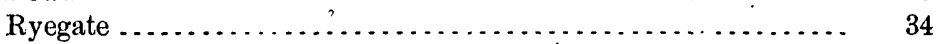

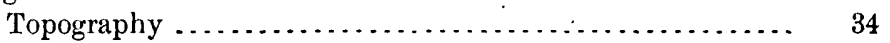

General geology ................................. 35

Description of Ryegate granite .................. 35

Geology of Ryegate granite quarries ............... 35

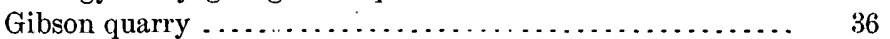

Morrison quarry ............................... 37

Italian quarry . . . . . . . . . . . . . . . 37

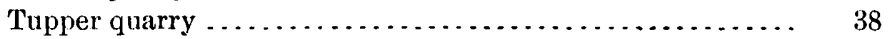

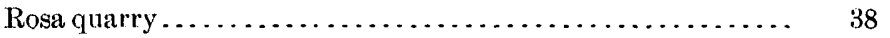

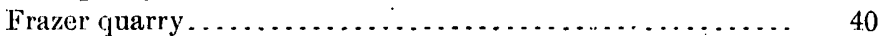

Groton ................................. 40

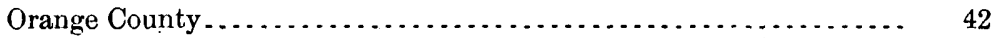

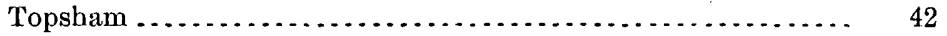

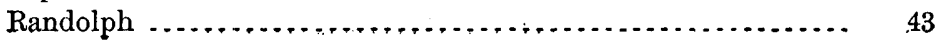


Part II. Economic Discussion-Continued.

Description of the granites and quarries-Continued.

Orleans County ...................................... 45

Newport Granite Company's quarry ................... $\quad 45$

Parmenter quarry ..................................... 46

Washington County .................................. 47

Barre and Williamstown ........................... 47

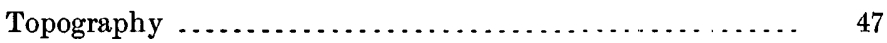

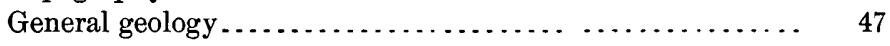

"Barre granite" ................................ 50

Geology of Barre quarries....................... $\quad 52$

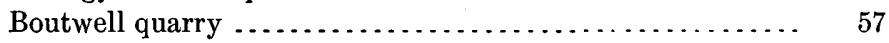

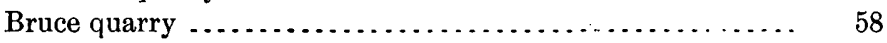

Milne \& Wylie quarry $\ldots \ldots \ldots \ldots \ldots \ldots \ldots \ldots \ldots \ldots \ldots . .6 . \ldots$

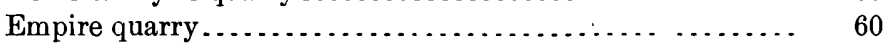

Marr \& Gordon quarry ........................... 61

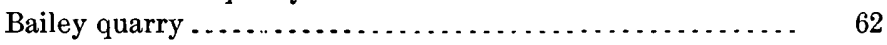

Barre Granite Company's quarry ................... 63

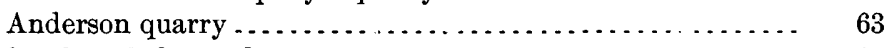

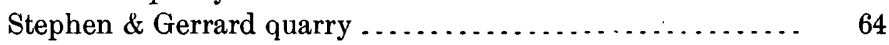

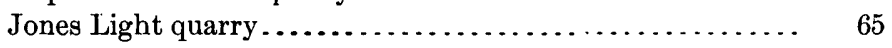

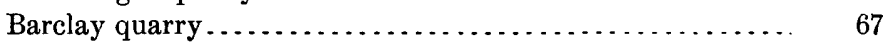

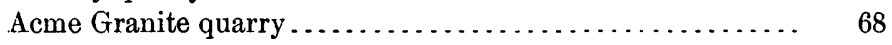

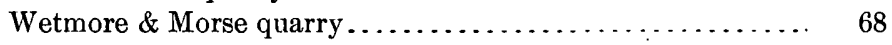

Smith Upper quarry ............................... $\quad 69$

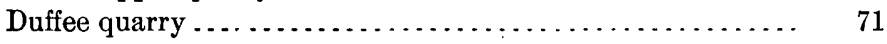

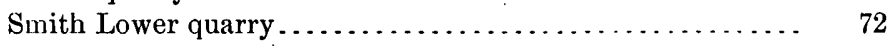

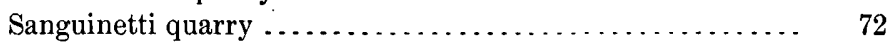

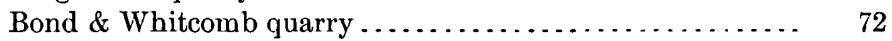

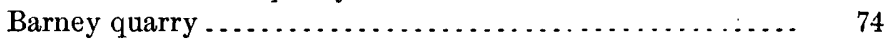

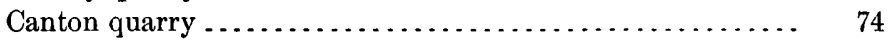

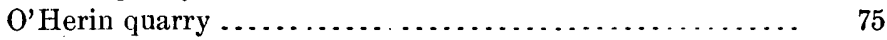

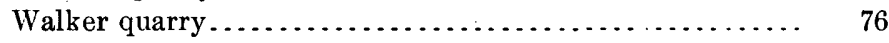

Wells-Lamson quarry ............................ $\quad 76$

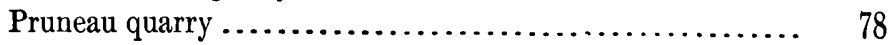

Consolidated Marr \& Gordon quarry . . . . . . . . . . . . . . . $\quad 78$

McDonald \& Cutter quarry ........................... $\quad 79$

Innes $\&$ Cruikshank quarry . . . . . . . . . . . . . . . . . . $\quad 80$

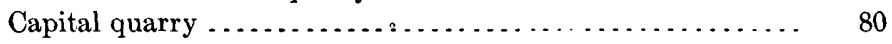

Couyellard quarry $\ldots \ldots \ldots \ldots \ldots \ldots \ldots \ldots \ldots \ldots \ldots \ldots, \quad 81$

McIver \& Matheson quarry ........................ 81

Manufacturers' quarry ............................... 82

Barre quarry....................................... 83

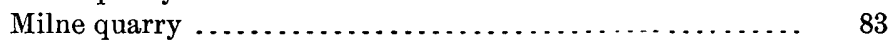

Barre Medium quarry ............................ 84

Empire Granite Company's quarry ................. $\quad 84$

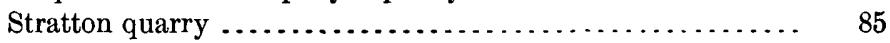

Jones Dark quarry .............................. $\quad 85$

Jones Small Dark quarry $\ldots \ldots \ldots \ldots \ldots \ldots \ldots \ldots \ldots \ldots \ldots$

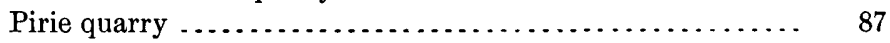

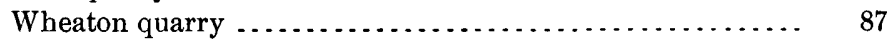

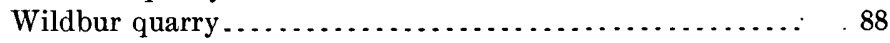

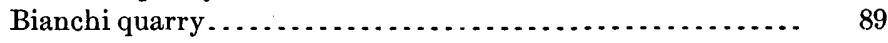

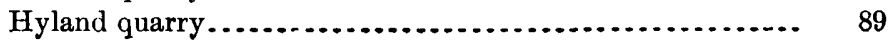


Part II. Economic Discussion-Continued.

Description of the granites and quarries-Continued.

Page.

Washington County-Continued.

Cabot

Calais

General statement.............................. 90

Patch quarry $. . . \ldots \ldots \ldots \ldots \ldots \ldots \ldots \ldots \ldots \ldots \ldots . . .61$

Lake Shore quarry $\ldots \ldots \ldots \ldots \ldots \ldots \ldots \ldots \ldots \ldots \ldots, \quad 92$

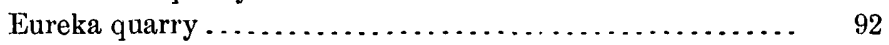

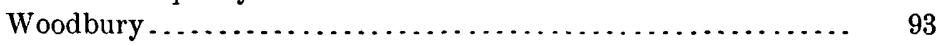

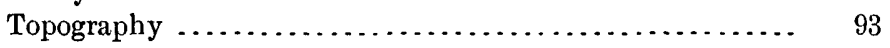

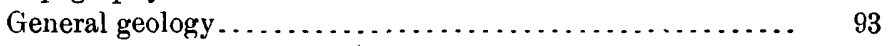

"Woodbury granite"............................. 94

Geology of Woodbury quarries.................... 95

Fletcher quarry ................................... 96

Woodbury Granite Company's quarries............... 98

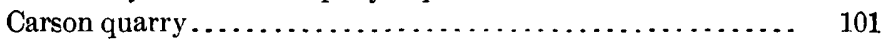

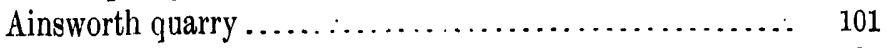

Miller quarry ................................. 101

Drenan quarries............................ 102

Light Granite prospect $\ldots \ldots \ldots \ldots \ldots \ldots \ldots \ldots \ldots \ldots \ldots . \quad 103$

Webber quarries ............................... 103

Fryatt \& Carr prospect........................... 104

Buck Pond quarries and granites................. 104

Chase quarries ............................... 104

Nichols Ledge Carter quarry .................... 105

Windhain County .................................... 105

Dummerston..................................... 105

General statement............................... 105

Black Mountain quarry........................ 106

Clark quarries ................................. 108

Bailey prospects.............................. 108

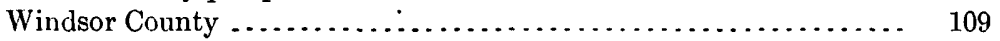

Bethel.......................................... 109

Topography and general geology................. 109

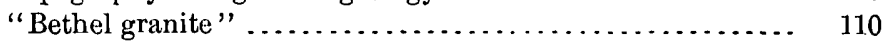

Ellis quarry .................................... 112

Woodbury Company's quarry.................... 114

Rochester...................................... 115

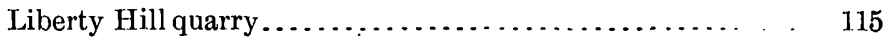

Windsor ............................................. 116

Topography and general geology $\ldots \ldots \ldots \ldots \ldots \ldots \ldots \ldots . \ldots \ldots$

"Windsor granite" ............................ 116

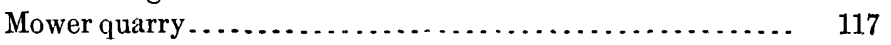

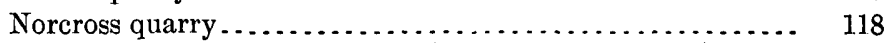

Characteristics and adaptation of Vermont granites ............... 119

Classification of Vermont granites .............................. 119

Commercial values of Vermont granites ...................... 122

Statistics of granite production in Vermont, by Altha T. Coons......... 1.22

Methods in the use of explosives ............................. 126

Bibliography of economic geology of granite .................. 127

Glossary of scientific and quarry terms ....................... 130 


\section{ILLUSTRATIONS.}

Plate I: Map of Barre and Williamstown quarries..................... 48

II. $A$, Nodular granite from Bethel; $B$, Schist and granite in alternating bands, Barre and Ryegate...............................

III. A, Carved statue of "Barre granite;" $B$, Sheet structure, Black Mountain, Dummerston .................................

IV. A, Carved panel of "Woodbury granite;" $B$, Double sheet structure, Robeson Mountain, Woodbury..........................

V. $A$, Carving of white granite from Bethel; $B$, Polished and cut green syenite from Mount Ascutney..........................

FIgURE 1. Map of Vermont, showing granite centers and prospects.........

2. Channel holes at Canton quarry, Barre, showing effect of com-

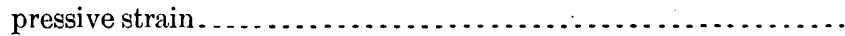

3. Structural relations of granite and schist, Bethel...............

4. Thin section across granite and schist, Bethel................

5. Structural relations of granite and schist, Anderson quarry, Barre.

6. Details at contact of granite and schist, Anderson quarry, Barre..

7. Mica slate with minute dikes of pegmatite and lenses of apatitic granite from contact with granite at Anderson quarry, Barre....

8. Map of Woodbury quarries and granite railroad.................

9. Map of Kirby quarries and Newark prospect.................

10. Map of Ryegate, Groton, and Topsham quarries..............

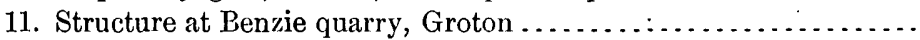

12. General topographic section through granite mass at Barre.......

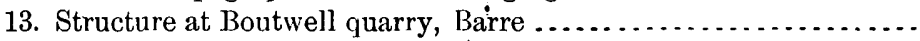

14. Structure at Empire quarry, Barre.........................

15. Structure at Stephen \& Gerrard quarry, Barre...............

16. Structure on north wall of Stephen \& Gerrard quarry, Barre .... .

17. Structure at Jones Light main quarry, Barre ................

18. Structure at Smith Upper, Smith Lower, and Duffee quarries,

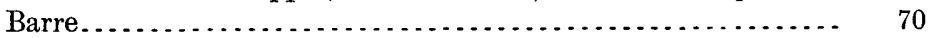

19. Structure at.Barney quarry, Barre...................... 74

20. Structure at Consolidated Marr \& Gordon quarry, Barre ........ $\quad 79$

21. Structure at Milne quarry, Barre ....................... 83

22. Structure at Pirie quarry, Williamstown ................. 87

23. Structure at Woodbury Granite Company's quarries, Robeson Mountain, Woodbury ............................. 100

24. Map of Bethel, Randolph, and Rochester ................ 110

25. Structure at Ellis and Woodbury granite companies' quarries, Bethel........................................... 


\title{
THE GRANITES OF VERMONT.
}

\author{
By T. Nelson Dale.
}

\section{INTRODUCTION.}

It is not proposed to present in this bulletin an exhaustive geologic and petrographic account of Vermont granites. For such a work years of geologic exploration and much petrographic skill and study would be required; but it is proposed for immediate economic purposes to locate definitely, describe briefly, and classify all known granites of present or prospective economic value within the State. The method of treating the subject will, like that adopted in the bulletins on the granites of Maine ${ }^{a}$ and on those of Massachusetts, New Hampshire, and Rhode Island, ${ }^{b}$ be both scientific and economic. Features of general geologic interest presented by the stone and the quarries or their immediate vicinity, as cursorily examined, and features of economic interest, particularly those resulting from the location, character, or structure of the stone, will both receive due attention.

The elementary facts as to the origin, composition, physical properties, texture, structure, variations, discoloration, and decomposition of granite, together with a summary of the methods of classifying, testing, and quarrying it, will be found, in a form intended for general readers, in Bulletin No. $354,{ }^{b}$ pages 9 to 72 .

The field work upon which this report is based was done in 1907, when 79 quarries and prospects were visited. One small quarry was visited in 1909. Prof. G. H. Perkins, state geologist, collected data from two prospects. Dr. Albert Johannsen, of the United States Geological Survey, critically revised the writer's petrographic determinations. Mr. W. T. Schaller, chemist, of the Survey, determined the percentages of lime soluble in acetic acid in 10 specimens of granite. Miss Altha T. Coons, of the Survey, has contributed some statistics of Vermont granite production. Dr. G. P. Merrill, of the United States National Museum, has rendered some bibliographic

$a$ Dale, T. N., The granites of Maine; with an introduction by George Otis Smith: Bull. U.S. Geol. Survey No. $313,1907$.

b Dale, T. N., The chief commercial granites of Massachusetts, New Hampshire, and Rhode Island: Bull. U. S. Geol. Survey No. 354, 1908. 
aid. The results obtained by Finlay and Daly from their special studies of certain Vermont granites have been utilized and will be referred to in their place.

As in Bulletins 313 and 354, the number of each specimen described, to which that of one or more thin sections corresponds, is given, so that the description can be verified by consulting the collections at the National Museum. These specimens, except those from idle quarries, have been prepared from blocks selected by the foreman or superintendent. The words "coarse," "medium," and "fine," as applied to granite, are to be understood as in the two previous granite bulletins: Coarse, with feldspars over 0.4 inch; medium, with those under 0.4 and over 0.2 inch; fine, with those under 0.2 inch. The Rosiwal method of estimating mineral percentages has been applied as far as practicable to the principal types of granite described. These types are defined and classified for economic purposes in the table on page 120, a bibliography of the economic geology of granite is given on page 127 , and a glossary of scientific and quarry terms will be found on page 130 .

The names applied to the various granites in this report are, with a few exceptions, merely local or trade designations. Their employment in this economic bulletin does not affect the standing of any particular name as a geologic formation name. 


\section{PART I.-SCIENTIFIC DISCUSSION.}

\section{GEOGRAPHIC DISTRIBUTION OF VERMONT GRANITES.}

Not until a contour map of the mountainous portions and of the eastern half of the State is completed and a careful geologic survey based upon such a map is made will the geographic distribution and extent of the granite areas of Vermont be accurately known. According to the geologic map of the State traced and compiled by the authors of the state report of $1861^{a}$ and also according to the geologic map of Orange and parts of Washington and Windsor counties by C. H. Richardson, ${ }^{b}$ a series of granite areas, varying greatly in size but mostly small, extend in a north-northeasterly direction between the central Green Mountain axis on the west and Connecticut River on the east for almost the entire length of the State.

The distribution by counties of all the granite quarrying centers and of the prospects included in this bulletin is shown in figure 1. At the extreme north end of the State, in Orleans County, granite is quarried in Derby, east. of Lake Memphremagog. Near the northeast corner of Caledonia County, the next county south, there is a granite prospect in Newark; and there are several quarries in Kirby about 14 miles south of Newark. There are also several quarries near the western corner of this county, 20 to 23 miles west of Kirby, in Hardwick; and the quarries of Ryegate and Groton lie near its southern edge. In Washington County, the southern half of which adjoins Caledonia on the west, there are three groups of quarries: The Woodbury quarries at the north, and east of them a prospect in Cabot; south of Woodbury the quarries in Calais; and 20 miles southwest of Woodbury and 8 miles southeast of Montpelier, the quarries of Barre, which is the chief granite-producing center of the State. A few of the Barre district quarries lie south of the Orange County line. About 20 miles southwest of Barre is the granite prospect of Randolph in Orange County. In the northern part of Windsor

$a$ Hitchcock, C. H. and E., jr., and Hagar, A. D., Report on the geology of Vermont, vol. 2, 1861, PI. I. This map, valuable as it is, can to-day hardly be regarded as more than a reconnaissance map. Some of its granite areas are wrongly located, and granite has been found where the map does not show any.

$b$ Richardson, C. F., The terranes of Orange County, Vt.: Rept. State Geologist of Vermont, 1902, Pls. IX and IX, $A$. 
County is the small but important white granite area of Bethel; 10 miles southwest of it is a quarry in Rochester, and 33 miles southsoutheast of Bethel and near the Connecticut is the green syenite of Mount Ascutney in Windsor and West Windsor. Finally, in Wind-

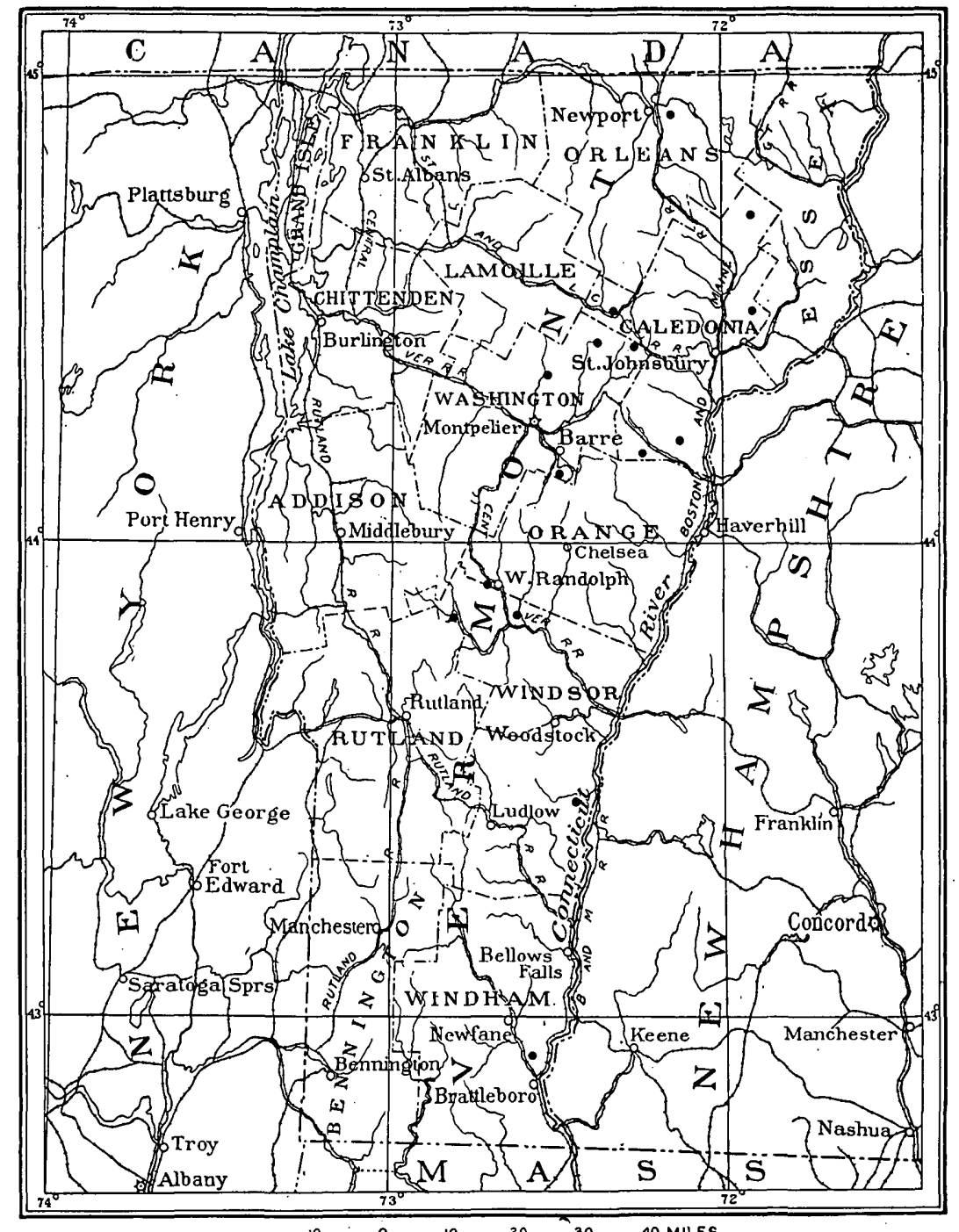

FIGURE 1.-Map of Vermont, showing granite centers and prospects $(\bullet)$.

ham County, toward the southern border of the State, 37. miles south-southwest of Ascutney, near Brattleboro and the Connecticut, are the light-granite quarries of Dummerston. 


\section{GENERAL PETROGRAPHY OF VERMONT GRANITES.}

The granites of this bulletin fall into three petrographic groups: Biotite granites, quartz monzonites, and hornblende-augite granites. In biotite granites the mica is almost entirely the black magnesia mica known as biotite. In quartz monzonite the soda-lime feldspar occurs in unusual amount, nearly equaling or even exceeding that of the potash feldspars. In hornblende-augite granite the dark silicates, hornblende and augite, take the place of the micas. The gray granites of Barre, Calais, and Woodbury and the pinkish of Newark are biotite granites. This granite also occurs at one of the Ryegate and one of the Kirby openings. The white granites of Bethel, Randolph, Rochester, the very light gray of Dummerston, the gray of Cabot, Derby, Groton, Hardwick (Buffalo Hill), Kirby, South Ryegate, and Topsham are quartz monzonites. The green syenite of Mount Ascutney is a hornblende-augite granite.

As a paragraph on the petrographic characteristics of the stone of each of these places precedes its detailed description in connection with that of the quarries it will suffice here to note the peculiarities of some in each group.

Biotite granite.-In "Barre granite" the plagioclase ranges from oligoclase-albite to oligoclase and oligoclase-andesine. The amount of $\mathrm{CaCO}_{3}$ indicated by two acetic acid tests is nearly 1 per cent, and the orthoclase particles show much carbonate. A marked feature of this granite is the freshness of its microcline and the general kaolinization and micacization of its orthoclase. Some particles of orthoclase inclose microcline. In two dark-gray granites of Barre the contrast between the hammered and cut face is as marked as it usually is in diorites and quartz monzonites, indicating the presence of more plagioclase than in ordinary biotite granites, a feature which the microscope corroborates. In the stone of Calais, which resembles that of Barre, the feldspar, second in abundance, is oligoclase-albite. In the "Woodbury granite" it is oligoclase-albite to oligoclase, exceptionally oligoclase to oligoclase-andesine, and the $\mathrm{CaCO}_{3}$ is 0.28 per cent. The biotite-granite of South Ryegate has oligoclase and only 0.05 per cent of $\mathrm{CaCO}_{3}$. The granites of Kirby and Newark have albite to oligoclase-albite and the latter has 0.41 per cent of $\mathrm{CaCO}_{3}$.

Quartz monzonite.-The coarse white granite of Bethel contains oligoclase and its mica is mostly muscovite. None of the sections or polished specimens obtained show magnetite or pyrite. The only available analysis shows only 2.56 per cent of $\mathrm{CaO}$ and the $\mathrm{CaCO}_{3}$ indicated by acetic acid test is only 0.12 per cent. The flow structure is marked by courses of discoid nodules of mica described more fully on page 25. In the coarse white granite of Rochester the feldspar is largely albite to oligoclase-albite. Muscovite is in conspicuous 
aggregates, roughly parallel, producing a gneissoid structure. It is also in minute scales through the feldspars. The amount of $\mathrm{CaCO}_{3}$ indicated is unusually high, 2.46 per cent. The very fine white granite of Randolph has albite to oligoclase-albite, and the muscovite is in scarcely perceptible scales and in finer microscopic ones in the feldspars. The $\mathrm{CaCO}_{3}$ indicated is 0.66 per cent. The very lightgray medium-grained granite of Dummerston has oligoclase to oligoclase-albite and both micas. These are intergrown and bent or twisted with sericite stringers extending from them into the other particles. Crush borders appear about quartz and feldspar. The $\mathrm{CaCO}_{3}$ indicated is 0.125 per cent. The dark-gray stone of Cabot has oligoclase and the mica is almost entirely biotite. The lightgray granite of Derby has oligoclase and both micas. No pyrite or magnetite was detected. The $\mathrm{CaCO}_{3}$ indicated is only 0.09 per cent. The bluish-gray granite of Groton and Topsham has oligoclase and the mica is nearly all biotite. The very dark-gray granite of Buffalo Hill in Hardwick has oligoclase to oligoclase-andesine. The percentage of quartz is low, 21.75, and that of biotite high, 16.19. The gray granite of South Ryegate has oligoclase and its mica is almost entirely biotite.

It will be observed that the microscopic descriptions of these various granites note the arrangement of the cavities within the quartz particles in intersecting sheets and their relation to the rift and grain cracks. ${ }^{a}$

Hornblende-augite granite.-This is the olive-green syenite, "nordmarkite phase" of Daly, exhaustively described in his monograph on Mount Ascutney. ${ }^{b}$ Its feldspar appears to be albite and oligoclase more or less obscurely intergrown with orthoclase and also rarely occurring separately. Biotite is present in places. Daly has shown experimentally that the green color which appears soon after exposure is due to the oxidization of extremely minute blackish granules of ferrous oxide in the feldspars and to the combination of the yellowishbrown color from the limonite thus produced with the bluish-gray of the unaltered feldspar. To judge from what has been found in other green granites and from the presence of allanite in this rock, a part of this limonite stain is probably due to the oxidation of allanite particles. $^{c}$ Daly estimates that this granite contains about 6 per cent more soda-lime than potash feldspar. The strong contrast of shade between its cut and polished surface, as shown in Plate V, $B$, also points to a large percentage of soda-lime feldspar.

$a$ This subject is discussed and illustrated in Bull. U. S. Geol. Survey No. 354, pp. 42-48 and fig. 1. $b$ Daly, R. A., The geology of Ascutney Mountain, Vermont: Bull. U. S. Geol. Survey No. 209, 1903. c See Bull. U. S. Geol. Survey No. 354, p. 52 and fig. 3. 


\section{GEOLOGIC RELATIONS OF VERMONT GRANITES.}

These studies have not thrown new light on the problem of the geologic relations and age of the granites, although they have brought out some previously known facts in greater definiteness and detail.

The biotite granite of Barre contains inclusions up to 57 by 10 by 6 feet of quartz-biotite-muscovite schist and quartz-biotite schist interbedded with quartzite, the details of which are described more fully on page 18 and shown in Plate II, $B$. At two or more of the Barre quarries (pp. 21,23), the granite is in contact with a similar schist, and minute dikes of pegmatite, starting from the granite surface, penetrate the schist, which near the contact is spotted with granitic lenses as described on page 22 . The schists and mica slates of Barre are in many places spangled with biotite and ilmenite (?). As they contain beds of quartzose crystalline limestone they are clearly of sedimentary origin. (See p. 49.)

On Robeson Mountain in Woodbury the contact of granite and schist is also observable. (See p. 23.) Minute pegmatite dikes from the granite surface penetrate the schist, and the granite carries inclusions of the schist measuring up to 25 by 10 feet. The schist of the original capping here is a biotite-muscovite-quartz schist containing beds of dark calcareous muscovitic, or in places epidotic, quartzite. At one quarry a small inclusion of fine-grained quartzose marble was found. These beds are also all of sedimentary origin.

The southern face of Blue Mountain in Ryegate consists of schists and very quartzose mica slate; its upper portion is granite, mostly quartz monzonite. This also contains inclusions of schist (quartzmicrocline-biotite) as described on page 19 and shown in Plate II, $B$.

The coarse white quartz monzonite of Bethel is bordered by a zone of fine-grained, more biotitic, and thus grayish quartz monzonite produced by more rapid cooling along the contact with a schist mass. The details of these relations are given on page 20 . In places the schist is a fine-grained garnetiferous mica slate with small calcareous beds spangled with biotite. The "Bethel granite" contains inclusions up to 21 by 12 by 5 inches, of very fine black biotite-orthoclaseoligoclase schist apparently not related to the schists and slates surrounding the granite area.

At one quarry in Derby the foreman stated that a dark slaty rock occurred in contact with the granite (quartz monzonite with both muscovite and biotite) on the west, the plane of contact being very steep; but this was covered in 1907 by the falling in of drift.

Schist occurs in the village of Adamant in Calais, within a small fraction of a mile of a ridge of biotite granite. 
On Buffalo Hill in Hardwick a very biotitic quartz monzonite is in contact with a medium-grained biotite-quartz schist containing zoisite.

The inference from the contacts and inclusions referred to is that the gray biotite granite of Barre, Calais, and Woodbury, the white quartz monzonite of Bethel, and the gray of Ryegate and of Buffalo Hill in Hardwick, and probably that of Derby, were intruded into certain mica schists and mica slates which are metamorphosed clayey and sandy sediments. Whether the intrusion of granites of such diverse characters as those of Barre, Bethel, and Hardwick was simultaneous can not yet be determined.

The green syenite (hornblende-augite granite) of Mount Ascutney in Windsor is in contact with a mass of schist which crops out along the base of the mountain a little below the Norcross quarry and has been carefully traced by Daly on three sides of the syenite mass and mountain. ${ }^{a}$ He has also described the changes brought about in the schist by the intrusion of the syenite ${ }^{b}$ and shows a biotite granite intrusive in syenite on the eastern flank of the mountain.

In view of the pressure needful for the formation of granite the original thickness of the schist masses into which these various granites were intruded must have been very considerable. The present granite surfaces have only become exposed by the erosion of those schist masses. Views have changed as to the age of these schists. On Hitchcock and Hager's map the granite areas are represented as surrounded by "calciferous mica schist" which was regarded as not later than Devonian. ${ }^{c}$ Richardson in his papers and map ${ }^{d}$ subdivided the "calciferous mica schist" belt of Hitchcock and Hager into a calcareous formation (in places a marble but containing schist phases) which he finally designated Waits River limestone, and an overlying noncalcareous schist member, the Vershire schist. $\mathrm{He}$ associates this latter formation with a certain belt of slate which flanks the central Green Mountain axis on the east and extends from Lake Memphremagog south to Barnard and includes the roofing slate of Northfield and Montpelier. This slate he finally designated the Memphremagog slate. About 3 miles west of the head of Lake Memphremagog, at Willards Mills, Castlebrook, Magog, Province of Quebec, this slate bears abundant graptolites of lower Trenton age, and he also cites finds of crinoid stems and crushed graptolites at several

\footnotetext{
$a$ Daly, op. cit., map, Pl. VII.

$b$ Idem, pp. 33, 34.

c Op. cit., vol. 1, p. 470.

$d$ Richardson, C. H., The Washington limestone in Vermont: Proc. Am. Assoc. Adv. Sci., Boston meeting, vol. 47, 1898, pp. 295-296; also, The terranes of Orange County, Vt.: Rept. State Geologist of Vermont., n. s. 3, 1902, pp. 84, 97, 98, Pl. IX; and The areal and economic geology of northeastern Vermont: Rept. State Geologist of Vermont, n. s. 5, 1906, pp. 86, 90; also, The geology of Newport, Troy, and Coventry: Rept. State Geologist of Vermont, n. s. 6, 1908, pp. 274-279.
} 
points in the Waits limestone. ${ }^{a}$ In his last paper (p. 279) he subdivides the Memphremagog slate at the north into three members, separated by two limestone members, and places them all in the Ordovician.

Daly, basing his opinions on Richardson's results and inferences, regards the schist of Mount Ascutney as of Trenton or pre-Trenton age and the intrusion of the syenite as "of later date than the last great period of rock folding which has affected the Ascutney region," and says that" the balance of probability makes them of post-Carboniferous and pre-Cretaceous age." $b$

Great difficulties have been experienced on the west side of the Green Mountain range in distinguishing slates and schists of Cambrian, Trenton, and upper Silurian age, because of their petrographical identity in places and also because of the unexpected unconformity between the Cambrian and Ordovician, and the frequence of faults, as well as the general obscuration of original structure by cleavage. In view of that it will be well to proceed cautiously in discussing the age of slate and schist belts on the east side of that range. This is the more important because of the uncertainty of the geologic mapping, owing to the want of contour maps. In such a territory paleontologic evidence should be confirmed by carefully established areal and structural relationships in order to obtain final age determinations.

With the understanding that the age determinations obtained thus far are, for the reasons given, somewhat provisional, the schists and slates of central and eastern Vermont into which the various granites were intruded may be regarded as of Ordovician age and the intrusions as having taken place not during the post-Ordovician mountain-making movement, but during that which occurred at the close of Devonian or of Carboniferous time.

- Evidences are not wanting in the composition and microscopic structure of the granites and in their larger structures as exposed at the quarries that since their intrusion they have been subjected to one and possibly several crustal movements. (See pp. 17, 56, 57.)

The basic dikes which traverse the granite or their inclosing schists at Barre, Groton, and Mount Ascutney are of later, possibly Triassic date.

a See Richardson, op. cit., Rept. State Geologist of Vermont, 1902, pp. 94-98, and 1906, pp. 112-114; also 1908 , pp. 290, 291.

b Op. cit., pp. 20, 21. 
OUTLINE OF THE EARLIER GEOLOGIC HISTORY OF VERMONT GRANITES.

The general earlier history of the granites and associated rocks of eastern Vermont may be tentatively put in the following simple form:

(1) In Algonkian time a period of sedimentation followed by the intrusion of granitic rocks into the sedimentary beds. These granites are the present gneisses of the Green Mountain range.

(2) At the close of Algonkian time a crustal movement metamorphosing the Algonkian sediments into schists and the granites into gneisses. This movement was accompanied by folding and elevation. The earlier mountain system of the State was thus formed.

(3) In early Paleozoic time the submergence of a large area of Algonkian rocks and the deposition thereon of sediments resulting from the erosion of Algonkian land masses, together with calcareous sediments largely of organic origin.

(4) At the close of Ordovician time a crustal movement took place, metamorphosing the Cambrian and Ordovician sediments into schist, slate, and marble, and powerfully folding and also elevating them. Some of these schists and slates are those which now surround the granite areas in the eastern half of the State.

(5) After a long time interval, probably at the close of Devonian or Carboniferous time, another crustal movement occurred, accompanied by the intrusion of the schist mass by granitic material in a state of fusion with superheated water. The intrusion produced in places further changes in the schist and also injected it with dikes of pegmatite. Fragments of the schist became included in the granite.

(6) Not long after the crystallization of the granite it was traversed by granitic dikes (pegmatite and aplite).

(7) The schist and granite masses were traversed, possibly in Triassic time, by basic dikes (diabase, etc.).

(8) Atmospheric erosion of the Paleozoic schists and slates, begun at the close of Ordovician time, has finally removed those parts of the schist mass which covered the granite domes. This process of erosion has been accelerated by successive uplifts.

IMPORTANT GEOLOGIC FEATURES AT THE QUARRIES.

The following paragraphs are devoted to those geologic features of Vermont granite quarries which are of general interest because of their bearing upon the origin and constitution of granite. 


\section{DOUBLE-SHEET STRUCTURE.}

Robeson Mountain, in Woodbury, is a narrow granite ridge, attaining an elevation of about 1,100 feet above Hardwick station and some 930 feet above Woodbury (Sabin) pond. It is from 300 to 400 feet above the hollows on either side of it. Its axis trends from N. $80^{\circ}$ E. to S. $70^{\circ}$ W., describing a slight curve. Near its west-southwest end the Fletcher quarry cuts the ridge from southeast to northwest, and in 1907 had reached a depth of 40 feet. The sneets: exposed here are from 1 to 5 feet thick, horizontal at the top of the ridge, but curving over on the southeast with a dip of $15^{\circ}$ to $30^{\circ}$, as shown in Plate IV, $B$, and determining the slope of the ridge on that side. These sheets are, however, intersected by another set from 5 to 9 feet thick, dipping $5^{\circ}$ to $10^{\circ} \mathrm{S} .70^{\circ} \mathrm{W}$. in the direction of the axis of the ridge. In the Woodbury Granite Company's quarries, roughly about 1,750 feet N. $80^{\circ}$ E. of the Fletcher quarry, the sheets at the top of the ridge turn, dipping to the northern horizon. Lower down on the southeast side of the ridge they are from 2 to 18 feet thick and dip $20^{\circ} \mathrm{SSE}$., with an intersecting set which is horizontal and evidently corresponds to the second set of the Fletcher quarry.

The only explanation offered for this double-sheet structure is the existence at some time of a secondary compressive strain operating differently from that which produced the primary sheet structure to which the ridge owes its form, and giving rise to a nearly horizontal set of joints or sheet partings. There is now a marked compressive strain in the Fletcher quarry, operating from northeast to southwest, parting the sheets and giving rise even in the upper part of the quarry to horizontal strain fractures. Its existence lends support to such an explanation. In 300 granite quarries visited thus far by the writer this is the first case of double-sheet structure or horizontal jointing observed.

\section{COMPRESSIVE STRAIN".}

The existence of compressive strain in the granite quarries of New England has long been known. It has also been observed in other places and is believed to bear on the. origin of sheet structure $^{a}$ The effects of this strain have been noted at the following quarries in Vermont: The Woodbury Granite Company's quarry at Bethel, direction of strain, east-west; certain quarries in BarreBoutwell, strain north-south; Bruce, north-south, strong; Wells Lamson, north-south; Canton, west-east; in Woodbury, Fletcher quarry (see above), about northeast-southwest; in Groton, Benzie

$a$ See Bull. U. S. Geol. Survey No. 313, 1907, pp. 32-37, Pl. VII, $A$; and Bull. No. 354, 1908, pp. $25,28$. 4782-Bull. $404-09-2$ 
quarry, in all directions; in Ryegate, on Blue Mountain, Tupper quarry, east-west; in Dummerston, Black Mountain, Lyons quarry, N. $10^{\circ}$ E. to S. $10^{\circ}$ W., marked. ${ }^{a}$

The usual effect of such a strain is the closing of channels or the crushing of cores between drill holes. Figure 2 is reproduced from a sketch. A fracture or fault plane has arisen extending tangentially from the side of one drill hole to that of the next and a slippage of part of the core has occurred along it, giving the drill holes an elliptical outline and bringing them nearer together.

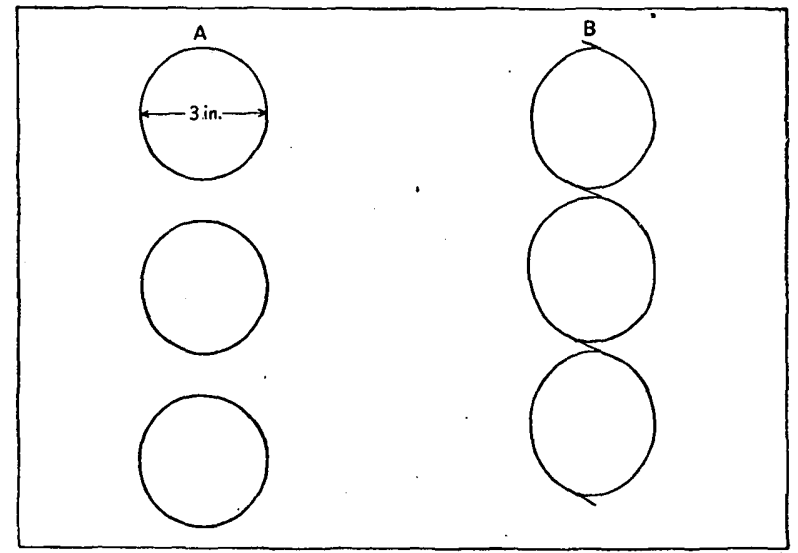

Figure 2.-Channel holes at Canton quarry, Barre, showing effect of compressive strain. A, Original drill holes, 3 inches in diameter; $B$, the same after operation of strain. Displacement along fractures, 1 inch.

SCHIST INCLUSIONS.

Among the notable features of Vermont granite quarries are the schist inclusions. Those at Barre have been briefly referred to by Finlay. ${ }^{b}$ Eighteen schist inclusions were noticed by the writer in the Barre quarries: Three at quarry 32 (Pl. I) ; one of these, 25 by 10 by 10 feet, has a foliation striking N. $30^{\circ}$ W. and dipping $60^{\circ} \mathrm{E}$.; another is 20 by 8 by 5 feet. The granite is slightly darker for a space of 7 feet from these inclusions. At quarry 25 several measure up to 8 by 2 feet. At quarry 8 two are 10 by 6 by 2 to 3 feet. One at quarry 6 is 20 by 5 feet. One at quarry 10, is 30 by 3 feet, tapering. The largest was at the Boutwell quarry, No. 1, measuring 57 by 10 by over 6 feet, with a foliation striking N. $10^{\circ} \mathrm{E}$. and dipping $55^{\circ} \mathrm{W}$. Another, 10 by 8 feet, has a foliation striking north and dipping: west. Some of these do not seem to have suffered much horizontal displacement, for their foliation nearly agrees with that of the schist, capping. In others it differs greatly.

$a$ See Bull. U. S. Geol. Survey No. 354, Pl. VIII, $B$.

$b$ Finlay, George I., The granite area of Barre, Vt.: Rept. Vermont State Geologist, No. 3, 1902, p. 51. 
The larger Boutwell quarry inclusion was examined in detail. Parts of it are lustrous dark-gray muscovite-biotite-quartz schist spangled with biotite flakes ( 0.15 inch long) and with garnets (about 0.05 inch). Parts of it consist of small beds of medium greenish gray fine-grained quartzite (grains to 0.2 inch) alternating with dark beds of quartz-biotite schist. The quartzite bands contain plates of green hornblende (to 0.75 by 0.37 millimeter) and larger garnets which inclose the quartz grains of the rock. The schist bands contain similar plates of biotite lying transverse to the bedding and the foliation. Both kinds of bands contain lenses of carbonate (up to 0.37 millimeter) and irregular particles and crystals of zoisite and epidote. As the schists of Barre away from the granite are spangled with various minerals (see p. 49) it is hardly possible to determine which if any of the isolated minerals in this mass was formed at the time of the granitic intrusion. The hornblende and garnet may have been. A few inches of the underside of this inclusion consist of interbanded granite and schist, the schist having evidently at the time of the intrusion been broken into slivers along its schistosity, and the semiliquid granite having been forced in between them. The specimen in Plate II, $B$, at the left, is from this point. It shows two minute dikes of granite ( 0.5 to 1.2 inches wide) penetrating the schist and ramifying. The main ones follow the foliation but the minor branches form very acute angles with it and taper out. 'A thin section made across one of these little dikes and the inclosing schist shows the former to be the typical biotite granite of Barre and the latter a quartz-muscovite-biotite schist spangled with biotite plates (to 0.1 inch). The quartz of the granite shows marked strain effects. The demarcation between granite and schist is sharp and no effect of granite upon schist appears.

At the Morrison quarry on Blue Mountain in Ryegate two schist inclusions were noticed measuring 8 by 4 and 3 by 1 foot. The edge of the larger one is injected with granite which fills lenticular spaces, as shown in Plate II, $B$, right. In another specimen the schist has sharp plications, 5 inches high, with lenses of smoky quartz parallel to them, but the nearest edge of the inclusion is nearly a plane surface. A thin section, 1.6 by 0.7 inches, across the edge of this inclusion shows a little granite dike, the quartz monzonite of the quarry, 0.3 to 0.6 inch thick, with schist on both sides. The latter is a quartz-microcline-biotite schist with a little muscovite and rare grains of oligoclase. It has lenses of biotite and muscovite in which large scales of each mica lie at right angles to one another. The sheets of cavities in the quartz of the granite are about parallel to the course of the dikelet and the foliation of the schist. Two other sections of the schist show much apatite in minute crystals and rare particles of allanite. The sheets of cavities in the quartz 
particles of the schist are at right angles to its foliation and do not penetrate the quartz of the granite. ${ }^{a}$

The general inference from these observations is that where a rock already schistose becomes included in granite the two may become somewhat minutely interbanded because of the ready fracture along the schist foliation, and that where such interbanding occurs the mineral changes in the schistose rock may be relatively slight. ${ }^{b}$

\section{CONTACT PHENOMENA.}

Those places where quarried granite is in contact with schist or slate have already been mentioned. At some of the Bethel, Barre, and Woodbury quarries the contact phenomena are of sufficient general interest to warrant more detailed descripitons.

BETHEL.

As already stated, the white granite at Bethel appears to be encircled by a zone of finer-grained light buff-gray granite, which is about

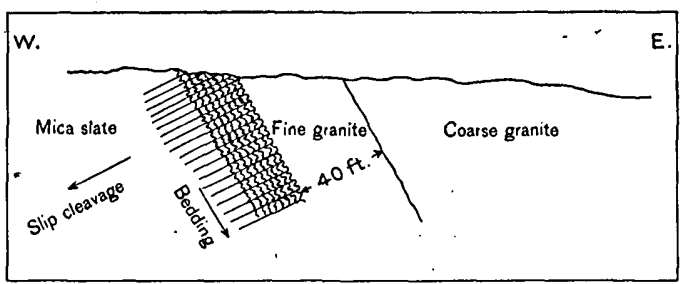

FIGURE 3.-Contact of quartz monzonite on the west side of Ellis quarry, Christian Hill, Bethel, Vt., showing relations of zone of fine granite to coarse granite and to bedding and cleavage of schist.
40 feet thick. Both rocks are quartz monzonites, but the finer contains more biotite scales than the coarser, and they are mostly very minute and evenly distributed. On the west side of the Ellis quarry the plane of contact between the coarse and fine granite strikes N. $15^{\circ} \mathrm{W}$. and dips $60^{\circ} \mathrm{E}$. The fine-grained granite is in contact on the west with a finely plicated, very fine grained quartz-muscovite-biotite schist, and this granite is finer grained at its contact with the schist than it is 20 feet away. The plane of contact strikes and dips about as that between the two granites, and the plications of the schist run parallel to this plane but are crossed by a slip cleavage striking N. $70^{\circ} \mathrm{W}$. and dipping $25^{\circ} \mathrm{WNW}$. The relations are shown in figure 3 . Figure 4 shows how the granite has been molded by the minute wrinkles in the schist. The schist contains a few small garnets and plates of magnetite. In the glassy zone the particles range from 0.009 to 0.03 millimeter. In the next the porphyritic feldspars measure as high as 0.92 by 0.5 millimeter. There are thus four grades of texture in the granite: The glassy, 1 to

$a$ See Bull. U. S. Geol. Survey No. 354,p. 46.

- $b$ In connection with this and the next subject the general reader will find some instructive matter in Kemp, J. F., A handbook of rocks for use without the microscope, 4th ed., New York, 1908: Generalities regarding contact metamorphism. 
2 millimeters thick; the very fine (porphyritic, at least toward the glassy), about 20 feet wide; the fine with feldspar and mica not over 1 millimeter, about 20 feet wide; and the coarse with feldspars up to 0.4 and 0.5 inch and mica to 0.3 inch, over 200 feet wide.

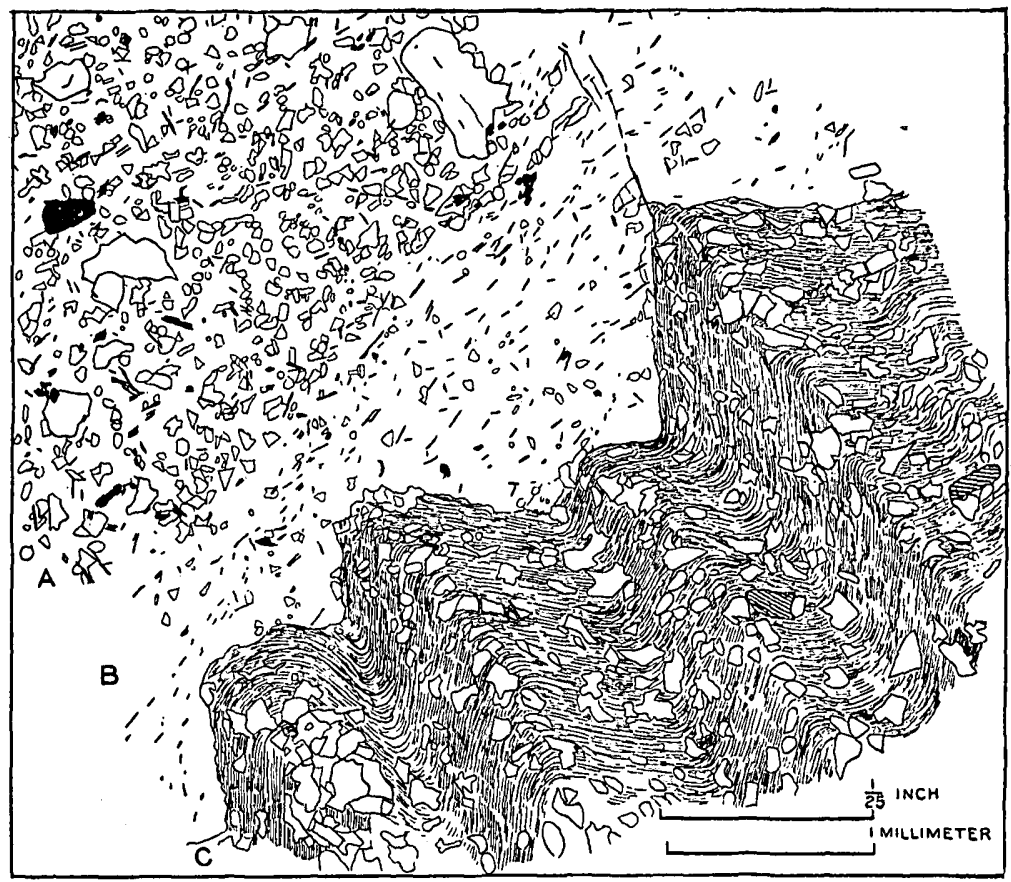

FIGURe 4.-Camera lucida drawing of enlarged thin section across contact of schist and granite at Bethel, Vt., shown in diagram in figure 3. A, Fine granite with some larger porphyritic feldspars and biotite scales. The finer undistinguishable particles of matrix are not shown. B, Zone, 1 to 2 millimeters wide, of glassy material with but few quartz and feldspar particles and biotite scales (in black); most of the latter with their long axis parallel to the general contact surface; a few at right angles to it. $A$ fracture with limonite stain crosses this zone. C, Sharply plicated schist of fibrous muscovite with a little biotite and much quartz (unshaded particles). The two shaded particles are nonmetallic opaque mineral.

BARRE.

The schist which overlies the granite is well exposed at several quarries. Finlay $a$ finds a darkened, more biotitic rim about a centimeter wide in the schist along the granite contact. At two quarries contact phenomena were well exposed at the time of the writer's visit. At the Anderson quarry (No. 8, Pl. I) the under surface of the schist is coarsely serrate, forming as it were a series of folds, which, however, are not structural. The granite is darker for a space of 25 feet from the schist, and a foot-thick pegmatite dike borders one of the schist tongues. (See fig. 5.) 
In the southern corner of this quarry pieces of the mica slate have scaled off from the mass and been carried a few inches into the granite. (See fig. 6.) At this point the schist is a purplish-gray, very quartzose mica slate of quartz-feldspar-biotite, in places with muscovite also, in others without feldspar. Generally the rock resembles the mica slates used for whetstones. The slate has little dikes of pegmatite which start from the granite surface with a thickness of 0.5 inch and taper out at a distance of 4 feet. The course of these dikes has no reference to the cleavage of the slate and their thickness is apt to be very irregular. The pegmatite consists, in descending order of abundance, of quartz, orthoclase, microcline, oligoclase-albite, and biotite. The quartz has cavities in sheets, some parallel to the dike, others across it. Minute particles of slate are here and there included in the pegmatite. The slate within

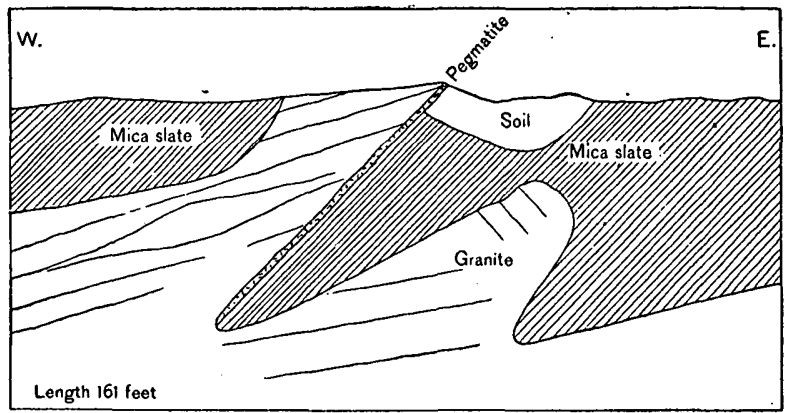

FIGURE 5.-Diagrammatic sketch showing relations of granite and mica schist and slate at Anderson quarry, Barre, Vt. Length, 175 feet.

a few inches of the granite is marked by very fine-grained, oval greenish-white spots, 0.1 to 0.5 inch and rarely 4 by 2 inches. These lenses lie with one of their major axes in the plane of the slaty cleavage. In some the biotite is zonally arranged, or the lens has a flange of biotite extending considerably beyond it and parallel to the slaty cleavage. Small ones $(0.15$ to 2.2 by 0.1 to 1 millimeter) were found in thin section to consist of granitic quartz with biotite and muscovite scales transverse or diagonal to the longer axis of the lens, and to be surrounded by a zone, 0.11 millimeter wide, of apatite particles. One has a little pyrite; another has apatite disseminated throughout it; another a little carbonate. The schist for a little space about the lens is finer grained than it is farther away. The little dikes do not show apatite except in rare, very minute prisms. Such dikes and lenses are shown in figure 7. 
These lenses have usually been regarded as the result of vaporous impregnation from the granite along the cleavage foliation. ${ }^{a}$ The slate about the lenses shows dark intersecting streaks which are due to more or less complete fractures lined with chlorite with a wide border of exceedingly minute undeterminable black particles.

At the Bailey quarry (No. 6, Pl. I) the contact is somewhat obscured by an inclusion which lies very near the schist capping. As the bedding of the inclusion strikes nearly east and west and that of the capping N. $20^{\circ}$ to $60^{\circ} \mathrm{E}$., the inclusion has been revolved. Both capping and inclusion have been shattered and injected with aplite and pegmatite. The schist, which is like that of the large inclusion at the Boutwell quarry, described on page 18, consists of little beds of whitish quartz-

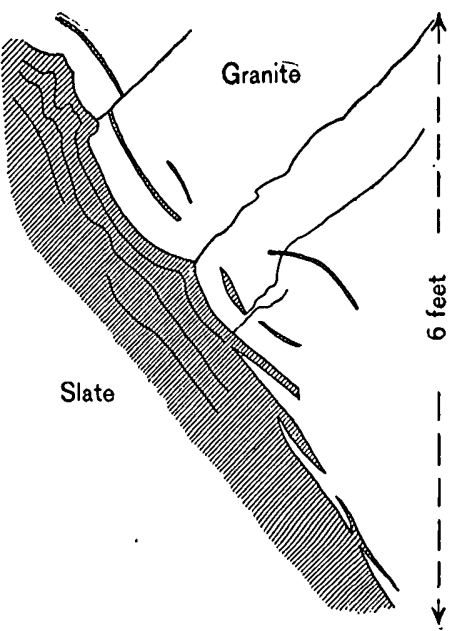

Figure 6.-Details at contact of mica slate and granite at south corner of Anderson quarry, Barre, Vt., as viewed along the strike of cleavage. Height, 6 feet. ite dotted with greenish hornblende and a few garnets, alternating

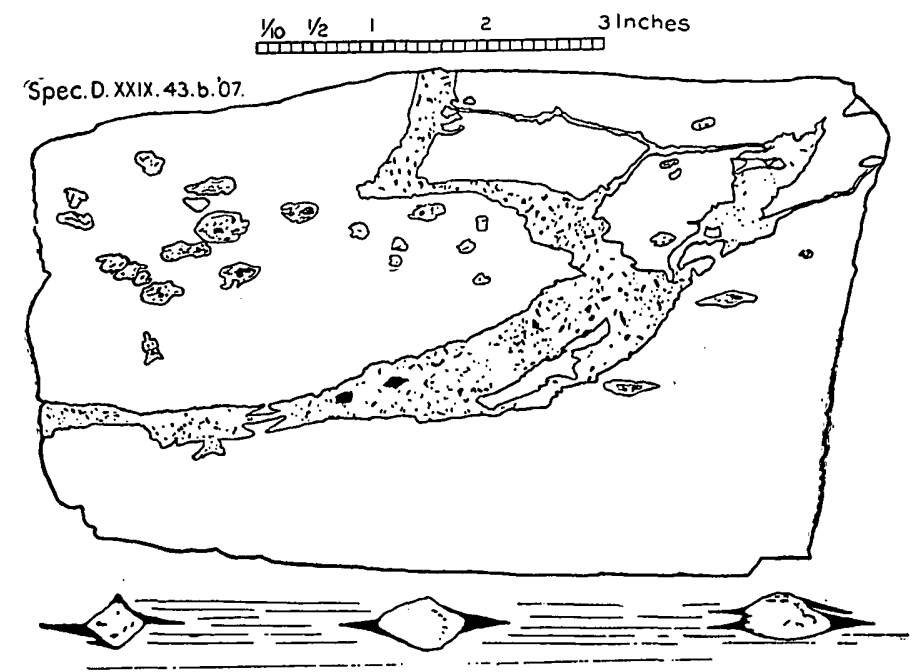

Figure 7.-Specimen of purplish-gray mica slate with minute dikes of pegmatite and lenses of apatitic granite, obtained near contact with granite at Anderson quarry, Barre, Vt. Cleavage parallel to length of block. At bottom several lenses (enlarged one-half) from other side of same specimen, showing biotite flanges and relation to cleavage.

$a$ Vogt regards apatite in veins as having been formed by pneumatolytic agencies. Vogt, J. H. L., Ueber die durch pneumatolitische Processe an Granitgebundenen Mineral-neubildungen: Zeitschr. prakt. Geologie, 1894, p. 458; and Die Apatit-Ganggruppe: Idem, 1895, pp. 367, 444, 465. Barrell describes the occurrence of apatite in a banded hornstone at contact with granite. He attributes this apatitization to pneumatoly tic impregnation. See Barrell, Joseph, Geology of Marysville mining district, Montana: Prof. Paper U. S. Geol. Survey No. 57, 1907, pp. 128, 130. For the formation of apatite at contact of diabase and granite, see Bull. U. S. Geol. Survey No. 354, p. 50. 
with little beds of quartz-biotite schist spangled with biotite scales ( 0.2 inch long). These beds are crossed by large and minute dikes of pegmatite. Some of them, only 0.3 to 0.4 inch wide, run transverse to the bedding for a space and then subdivide to pass at right angles within one of the little beds. Small hand specimens combining both transverse and longitudinal dike courses can be obtained here. The aplite here has a matrix of quartz, oligoclase-albite, microcline, particles 0.25 to 0.1 millimeter, with porphyritic feldspar and quartz from 0.25 to 1 millimeter.

WOODBURY.

The contact of granite and schist is finely exposed on the northwest side of Robeson Mountain along the granite railroad. The axes of the schist folds strike $\mathrm{N} .70^{\circ} \mathrm{W}$. and pitch $30^{\circ} \mathrm{S}$., while the axis of the hill runs about $\mathrm{N} .70^{\circ} \mathrm{E}$. The plane of contact appears to be about parallel to the strike. The schist is of two sorts. One is a dark, rather coarse biotite-muscovite-quartz schist with minute black particles and speckled with lenticular biotite plates (up to 0.75 by 0.25 millimeter) lying across the schistosity of the rock. Some plates have a nucleus of magnetite. There are also a few lenses of pyrite. The other sort, a thin bed of which touches the granite, is a dark, bluish-gray calcareous muscovitic quartzite abounding here with slender flattish six-sided prisms (up to 2 by 0.34 millimeters) of a light-colored hornblende. These are evidently the product of contact metamorphism. The granite sends little pegmatitic dikes into the schist. At the Webber quarry north of the mountain the capping is similarly injected.

All these contact phenomena lead to the following general inferences:

The 40-foot zone of fine-grained granite, with its three grades of texture, which intervenes between the coarse granite and the schist at Bethel, shows the effect of more rapid cooling upon texture. The material nearest the schist is glassy but that farthest away is coarsely crystalline. The semiliquid condition of the granite when it met the schist is shown by its having been molded by the delicate plications of the schist.

That the granitic intrusion at Barre was accomplished under great pressure is indicated by the intrusion of minute granitic dikes into such narrow transverse and longitudinal fissures in the schist and slate.

That the granitic intrusion at Barre was also attended by sufficient heat and moisture to inject the constituent elements of quartz, feldspar, biotite, pyrite, and apatite in vaporous condition into 
the cleavage foliation of the slate is shown by the position and character of the lenses described. The formation of these lenses also affected the texture of the slate.

That at Woodbury the same causes sufficed to produce minute hornblende prisms within a calcareous quartzite along the granite contact.

\section{ORBICULAR GRANITE.}

The white quartz (muscovite-biotite) monzonite of Bethel is crossed on the east side of the Ellis quarry (see p. 113 and fig. 25) by a belt a few feet thick which has a marked flow structure consisting of vertical micaceous bands half an inch or less wide, a foot or more apart, and with a northerly strike. The micas in these bands tend to arrange themselves about the quartz and feldspar particles and are roughly parallel. Near the granite surface there is here a branching mass of wrinkled bronze-colored micaceous material a foot thick lying in the plane of flowage. Biotite appears to be the chief constituent in this mass. In thin section it consists of coarse stringers of an olive-greenish biotite, more or less completely surrounding particles of quartz and soda-lime feldspar. There are also small scales of muscovite penetrating the quartz and feldspar particles. In this same flowage belt there are crowds of elliptical discoid nodules of bronze-colored mica from 0.7 to 0.5 to 2 by 1.5 inches, and about 0.2 inch thick. The surfaces of these disks are either longitudinally or concentrically corrugated. While most of these nodules are discoid, some of the smaller ones are nut shaped, resembling those in the well-known butternut granite of Craftsbury and Northfield, Vt. ${ }^{a}$

Aside from their discoid form, the noticeable features of the Bethel nodules are that they lie in sheets parallel to the flow structure and that the major axes of the disks are parallel to the micaceous flowage bands. Plate II, $A$, is from a photograph of a hand specimen containing one of the larger disks.

The attention of geologists was first called to the nodular granite of Craftsbury ("Craftsbury pudding granite") by Hitchcock and Hager in 1861. It was next described by Hawes in $1878,{ }^{b}$ and in 1885 in greater detail by Chrusthov, ${ }^{c}$ and again by the same geologist in an elaborate monograph in $1894 .^{d}$ He found that the nodules contained over twice as much calcite as the granite. As both the granite and nodules of Craftsbury differ from those of Bethel, his

$a$ See Hitchcock and Hager, Report on the geology of Vermont, 1861, vol. 2, pp 563, 564, 721; also .Jalc, T. N., Bull. U S. Geol. Survey No. 275, 1906, p. 90; Perkins, G. H., Report state geologist of Vermont; 1906, p. 108, Pl. XXXII, fig. 2.

$b$ Hawes, G., Geology of New Hampshire by C. H. Hitchcock, vol. 3, pt. 4, 1878, p. 203, pl. XI, fig. 4.

$c$ Chrusthov, Konstantin Dmitrijevie, Note sur le granite variolitique de Craftsbury en Amérique: Bull. Soc. min. de France, 1885, vol. 8, pp. 132-141.

$a$ Ueber holokrystalline makrovariolitische Gesteine: Mém. Acad. imp. des sciences de St. Pétersbourg, ser. 7, vol. 42, No. 3, 1894, Pudding granit von Craftsbury, Vt., pp. 132-146, pl. 2, fig. 9, and pl. 3, fig. 22. 
inferences do not exactly apply to the Bethel nodules. But a conclusion of Frosterus from the study of a nodular granite in Finland applies well to that of Bethel, and shows the real significance of its nodules. It is that the nodules are basic segregations lying in a more basic part of the granite, indicating that the orbicular structure is simply a basic flowage band ("Schliere") and that the nodules themselves lie in this as still more basic segregations. ${ }^{a}$

The nodules in orbicular granite vary greatly in composition, size, and structure. Orbicular granites have been described from Bohemia, California, Corsica, Finland, France, Germany, Greece, Ireland, North Carolina, Norway, Ontario, Portugal, Rhode Island, Sardinia, Scotland, and Sweden. The literature of the subject is already large, embracing forty-six papers and probably more. ${ }^{b}$

\section{DELIMONITIZATION ON THE UNDER SIDE OF SHEETS.}

At the Frazer quarry on Blue Mountain, in Ryegate, there is a band of rusty stain or "sap" along the base of a sheet 12 feet thick which dips $25^{\circ} \mathrm{SW}$. away from the mountain. Usually this limonitic stain affects the upper and lower parts of granite sheets for several inches from the sheet surface, but in this case the rusty band, which is only an inch thick, is separated from the lower sheet surface by an interval of 1 or 2 inches of clear granite. These rusty bands are due either to the oxidation of ferruginous minerals by clear water or to the deposition of limonite by ferruginous water-in both cases circulating between the sheet surfaces. (See, further, Bưll. 354, pp. 35, 56.)

A careful examination of the specimen shows that all the minerals in the rusty band are stained a medium brown, and that the space below it, although of the same color as that above it, yet has dots 0.1 inch wide of very dark brown. A thin section of this part shows limonite proceeding from biotite and allanite crystals. A thin section of the clear granite above the band shows no limonite whatever about a crystal of allanite. There seems, therefore, to have been a partial delimonitization of the lower part of the zone of "sap," which may be attributed to organic acids in the water circulating between the sheets after that which produced the stain.

$a$ Frosterus, Benj., Ueber ein neues Vorkomnis von Kugelgranit unfern Wirvik bei Borga in Finland, nebst Bemerkungen über ähnliche Bildungen: Tschermaks Min. pet. Mitt., Vienna, vol. 13, pt. 3, 1893, p. 187.

b See Zirkel, F., Lehrbuch der Petrographie, 2d ed., vol. 2, 1894, Kugelbildung, pp. 50, 51; also Rosenbusch, H., Mikroskopische Physiographie der Mineralien und Gesteine, 4th ed., vol. 2, 1907, Kugelstruktur, pp. 85-94. 


\section{PART II.-ECONOMIC DISCUSSION.}

\section{THE GRANITE RAILROADS.}

The granite industry of Vermont owes no small part of its present prosperity to "granite railroads," which connect not only groups of quarries, but every quarry in each group with the main line, although these quarries are situated at considerable elevations and are inconveniently related to one another. Plate I shows the intricate character of the granite railroad about Millstone Hill near Barre; figure 8 gives a general idea of that connecting Robeson Mountain in Woodbury with Hardwick, and figure 24 that leading from Christian Hill to Bethel.

\section{DESCRIPTION OF THE GRANITES AND QUARRIES.}

\section{CALEDONIA COUNTY.}

The quarries of this county are in the towns of Hardwick, Kirby, Newark, Ryegate, and Groton.

\section{HARDWICK.}

Professor Perkins, in 1906, called attention to a fine light granite quarried in this town by the Northern Granite Company, from which stone more than 50 statuettes had been cut. He also mentioned granite quarries at Mackville, a mile east of Hardwick village, as then operated by the same company. ${ }^{a}$ As none of these quarries were in operation in 1907 they were not visited by the writer.

The Buffalo Hill quarry is on Buffalo Hill about $2 \frac{1}{2}$ miles S. $60^{\circ} \mathrm{W}$. from Hardwick village and about 500 feet above it. (See map, fig. 8.) Operator, Hardwick Granite Company, Hardwick, Vt.

The granite (specimen D, XXIX, 58, a and d), "dark-blue Hardwick," is a quartz monzonite of dark-gray shade, a little darker than "dark Barre" and a trifle lighter than "dark Quincy." Its texture is medium, with feldspars up to 0.3 inch and mica to 0.2 inch, generally even grained but with sparse, clear, porphyritic feldspars up to 0.4 inch, inclosing the feldspars, quartz, and mica. Its constituents, in descending order of abundance, are smoky quartz with hairlike crystals of rutile, with cavities in sheets parallel to rift cracks and 
with another shorter and rarer set at right angles to the first; milk-white soda-lime feldspar (oligoclase to oligoclase-andesine), much kaolinized, somewhat micacized and epidotized, and containing calcite; in about equal amount with this feldspar a clear to bluish-

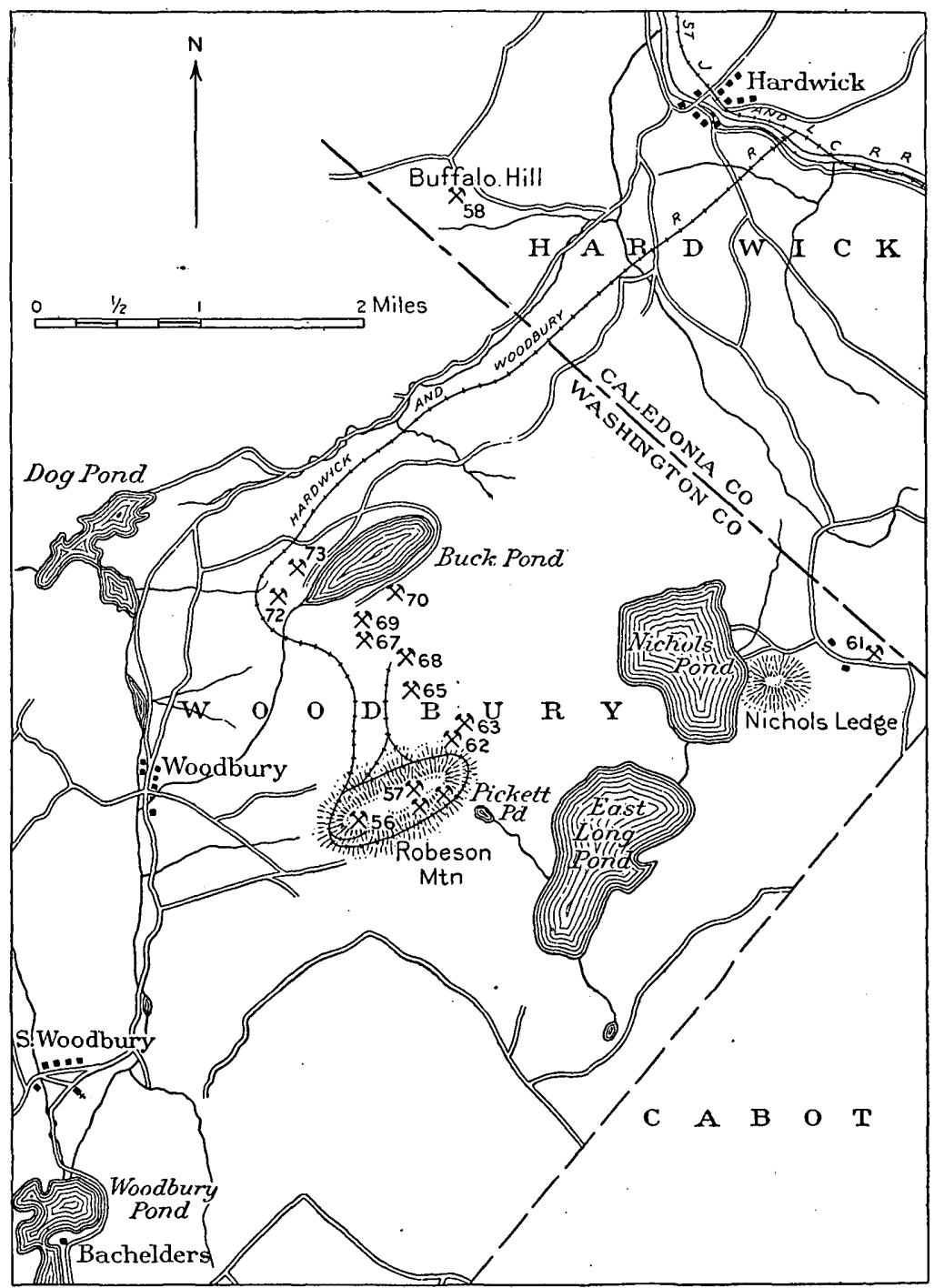

FIGURE 8.-Map compiled from various sources showing approximate locations of granite quarries in Woodbury, Washington County Vt. Quarries: 56, Fletcher; 57, Woodbury Granite Company; 61, Carter; 62, Carson; 63, Ainsworth; 65, Drenan; 67, Webber, new; 68, Webber, main; 69, 70, old quarries; 72, Leach; 73, Chase.

white potash feldspar (microcline with a little orthoclase), some of it kaolinized, some inclosing particles of all the other constituents; olive-colored biotite (black mica) with a little muscovite or bleached biotite. The accessory minerals are pyrite, magnetite, apatite, 
zircon (crystals), and allanite; the secondary, kaolin, a white mica, epidote, and calcite. The soda-lime feldspar is radially intergrown with quartz.

The stone effervesces slightly with dilute muriatic acid.

An estimate of the mineral percentages by the Rosiwal method gives. these results with a mesh of 0.4 inch and a total linear length of 38.8 inches.

Estimated mineral percentages in "dark-blue Hardwick" granite.

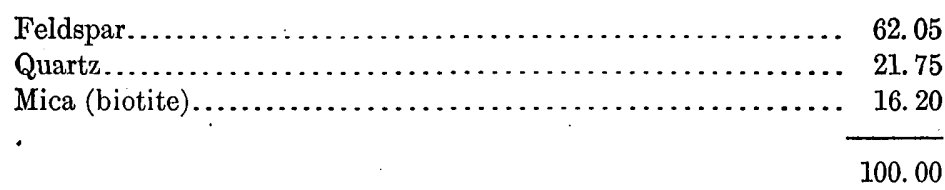

The average diameter of all the particles by the same calculation in 0.093 inch; that of feldspar, $0.106 \mathrm{inch}$; of quartz, $0.122 \mathrm{inch}$; and of mica, 0.052 inch.

This is a bright stone with strong contrast between the white feldspar and black mica. It takes a fair polish, and hammers light with marked contrast to the polished face, which shows some pyrite and less magnetite.

The quarry, opened about 1887, is a small irregular opening 20 to 30 feet deep. It is a bowlder quarry without sheets. There are the following joint systems: (a), strike, N. $30^{\circ} \mathrm{W}$., dip $35^{\circ} \mathrm{W}$., spaced about 10 feet; (b), strike, N. $45^{\circ}$ E., dip $40^{\circ} \mathrm{NW}$., spaced about 10 feet; (c), strike, N. $25^{\circ} \mathrm{W}$., dip $50^{\circ}$ to $75^{\circ} \mathrm{NE}$., spacing irregular. The rift is reported as vertical with N. $50^{\circ} \mathrm{E}$. course, and the grain as about like joints (a), but neither is marked. There are some white, probably feldspathic, and black biotitic "streaks," really veins, with curving course. Rusty stain up to 6 inches thick appears on joint faces.

The plant consists of one horse derrick.

Transportation is by cart $2 \frac{1}{2}$ miles to Hardwick.

The product is used for monuments, particularly for polished and rock-faced work.

KIRBY.

The quarries are all on Kirby Mountain in the east part of the township and about 9 miles northeast of St. Johnsbury. (See map, fig. 9.)

GROUT QUARRY.

The Grout quarry is on the south side of Kirby Mountain in Kirby, $2 \frac{1}{2}$ to 3 miles N. $20^{\circ} \mathrm{W}$. of North Concord and about 450 feet above the station there. (See fig. 9.) Operators, Carlton \& Lake, East St. Johnsbury, Vt. 
Grout quarry gray granite (specimen $\mathrm{D}, \mathrm{XXIX}, \overline{76}, \mathrm{a}$ ) is a biotite granite of light to medium, slightly bluish-gray color and of medium inclining to fine, even-grained texture with feldspars up to 0.25

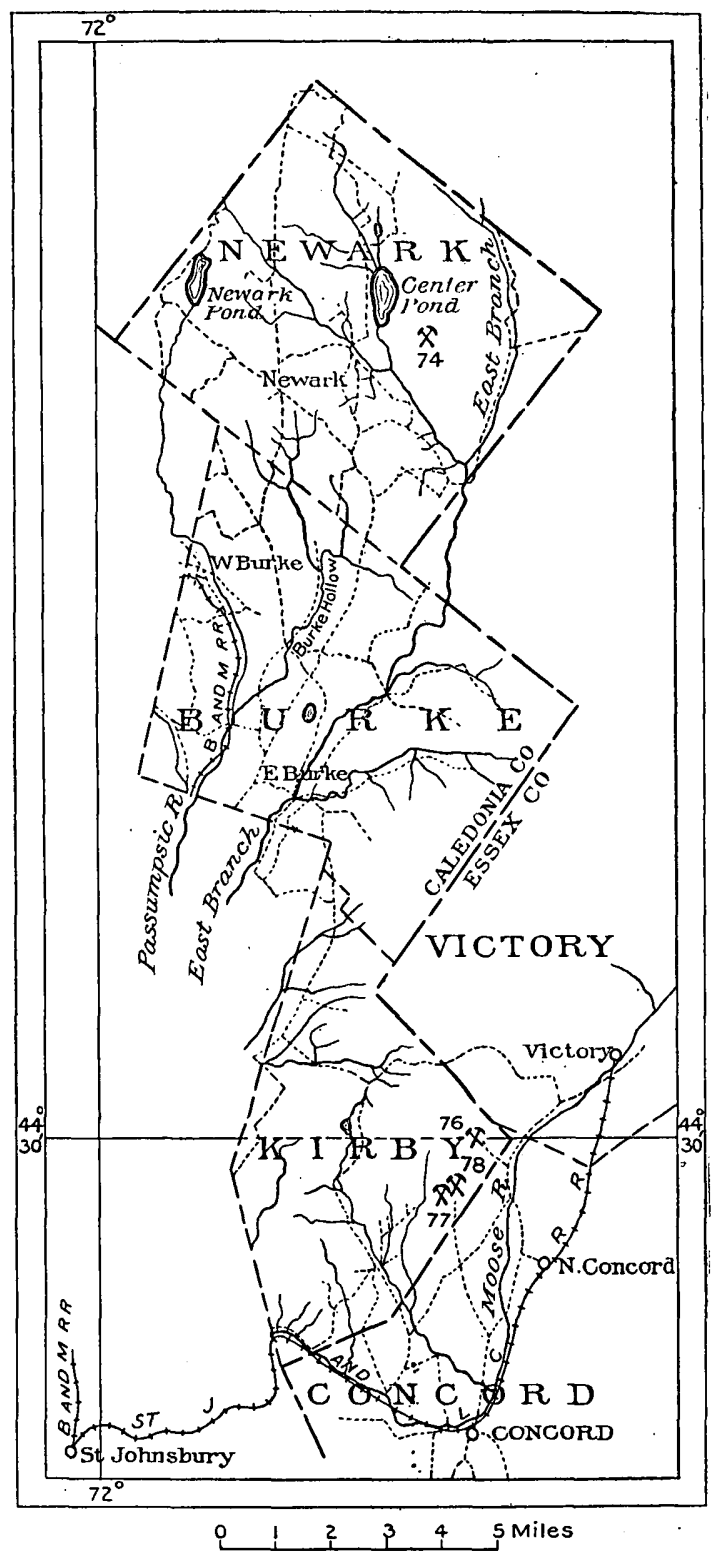

Figure 9.-Map of Kirby and Newark, from Beers's Atlas. 74 Bugbee; 76, Grout; 77, Kearney Hill; 78, Burke Granite Company. and mica to 0.1 inch. Its constituents, in descending order of abundance, are: Clear to translucent potash feldspar (microcline, with inclusions of the other constituents, and also orthoclase); light smoky quartz with cavities in sheets with a set of cracks parallel to them; milk-white soda-lime feldspar (albite to oligoclase-albite) much kaolinized and with some white mica; biotite (black mica) and a little muscovite or bleached biotite. Zircon is an accessory mineral. Neither magnetite nor pyrite was detected. Secondary minerals are kaolin and a white mica. The granite does not effervesce in cold dilute muriatic acid.

This is a bright stone, but the fineness of its mica and the light shade of its quartz preclude strong contrasts.

The quarry, opened about 1899 , consists of two openings, the northern and upper one 40 by 25 feet and 10 feet deep; the lower one 70 feet square and 3 to 5 feet deep. 
The sheets, from 6 inches to 4 feet thick, but obscure in the upper opening, strike N. $55^{\circ} \mathrm{E}$. and dip $25^{\circ} \mathrm{SE}$. The joints are: (a), vertical, strike N. $25^{\circ} \mathrm{W}$., spaced 1 foot to 2 feet 6 inches to 50 feet; (b) strike N. $85^{\circ}$ E., dip $55^{\circ} \mathrm{N}$., forming the south wall, spaced 6 to 8 feet; (c) strike N. $80^{\circ}$ W., dip $40^{\circ} \mathrm{N} .20^{\circ}$ E., spaced 9 feet. The rift is reported as vertical, with $\mathrm{N}$. $70^{\circ} \mathrm{E}$. course, and grain as horizontal. The flow structure, consisting of streaks of biotite, is parallel to rift. There are some biotitic knots. A vertical quartz vein, half an inch thick, strikes $\mathrm{N} .65^{\circ} \mathrm{E}$. Rusty stain is confined to the surface and the thinnest sheets next to it.

Three aplite dikes strike N. $80^{\circ} \mathrm{E}$. and are 6 feet 6 inches, 6 feet, and 1 foot thick. This aplite (specimen D, XXIX, $\overline{7} \overline{6}, \mathrm{~b}$ ) is dark gray and of very fine porphyritic texture. But few particles can be distinguished; feldspar 0.1 inch, mica 0.05 inch. It effervesces slightly with cold dilute muriatic acid. In thin section the particles of groundmass range from 0.037 to 0.148 millimeters, and consist, in descending order of abundance, of quartz, microcline (possibly also orthoclase), rare soda-lime feldspar, minute biotite scales, muscovite or bleached biotite, and secondary zoisite. The porphyritic particles and crystals are quartz, soda-lime feldspar, orthoclase, and biotite. One of the former feldspars has curved twinning planes, another is faulted across them, and has much secondary quartz about it, all indicating motion after crystallization. Calcite was not detected microscopically, but is present.

The plant consists of one horse derrick and one hand derrick.

Transportation is by cart 5 to 6 miles to rail at Concord.

The product is used for monuments.

KEARNEY HILL QUARRY.

The Kearney Hill quarry is on the west foot of Kirby Mountain, in Kirby, about $2 \frac{1}{4}$ miles, roughly, N. $55^{\circ}$ W. of North Concord. (See fig. 9.) It is operated by the Kearney Hill Quarry Company, Concord, Vt.

Gray granite of Kearney Hill (specimen D, XXIX, 77, a, b) is a quartz monzonite of light-gray shade with conspicuous fine black specks and medium inclining to coarse, generally even-grained texture, with feldspars up to 0.3 inch and mica to 0.2 inch, but with sparse porphyritic clear feldspars, embracing the other constituents, up to 0.5 inch. Its constituents, in descending order of abundance, are: Clear, colorless quartz with hairlike crystals of rutile and fluidal cavities in sheets; bluish to milk-white soda-lime feldspar (oligoclase), somewhat kaolinized and micacized, and inclosing much carbonate; some of it is intergrown with quartz in vermicular structure; clear potash feldspar (orthoclase and microcline, some of the orthoclase micacized); a large porphyritic orthoclase embracing all the other 
constituents; biotite (black mica), some of it chloritized; and a little muscovite. The accessory minerals are pyrite, allanite, apatite, zircon, and rutile. The secondary are kaolin, a white mica, chlorite, and calcite. There is some effervescence with cold dilute muriatic acid.

Owing to the larger size of the biotite scales and the clearness of the quartz the contrasts are more marked than in the stone of the Grout quarry, and the sheen of the porphyritic feldspars on the rough face is marked.

The quarry, opened in 1906, measures about 100 by 35 feet and 5 feet in depth.

The sheets, from 1 to 3 feet thick, are horizontal or inclined $15^{\circ} \mathrm{S}$. There is but one set of joints, which strikes N. $65^{\circ} \mathrm{E}$. and is vertical, and is spaced 5 to 20 feet. The rift is reported as horizontal and the grain as vertical, with $\mathrm{N} .20^{\circ} \mathrm{W}$. course. Biotitic knots are up to 1.5 inches across. A "shake" structure extends down to 16 inches from the surface.

The plant consists of one hand derrick.

Transportation is by cart $5 \frac{1}{2}$ miles to a cutting firm and rail at Concord.

The product is used for monuments.

BURKE QUARRY.

The Burke quarry is on the west foot of Kirby Mountain, in Kirby, about 1,000 feet N. $60^{\circ}$ E. from the Kearney Hill quarry, and about $2 \frac{1}{8}$ miles, roughly, N. $50^{\circ} \mathrm{W}$. from North Concord. (See map, fig. 8.) Operator, Burke Granite Company (Incorporated), East Burke, Vt.

The granite (specimen D, XXIX, $\overline{7} \overline{8}$, a) is a quartz monzonite of light to medium gray shade, and of medium inclining to fine, evengrained texture, with feldspars up to 0.25 inch and mica to 0.1 inch. Its constituents, in descending order of abundance, are: Light smoky quartz with hairlike crystals of rutile, and sheets of cavities with cracks parallel to them; milk-white soda-lime feldspar (oligoclase) much kaolinized and micacized, with some carbonate and epidote, and in places intergrown with quartz in vermicular structure; clear to scarcely bluish potash feldspar (microcline with inclusions of oligoclase, quartz, and mica, also orthoclase micacized); biotite (black mica) some of it chloritized; and muscovite (white mica). Accessory minerals are very little magnetite, apatite, zircon, and rutile. Secondary minerals are kaolin, a white mica, epidote, zoisite, carbonate, and chlorite. There is no effervescence with cold dilute muriatic acid.

This stone closely resembles that of the Grout quarry in its shade and weakness of contrasts.

The quarry measures about 175 by 100 feet and from 10 to. 20 feet in depth. 
Between this and the Kearney Hill quarry there is an outcrop of schist, either an inclusion or the original schist capping, which strikes N. $15^{\circ} \mathrm{E}$. The sheets, from 1 to 5 feet thick, dip $10^{\circ} \mathrm{S}$. There are three sets of joints: Set (a), striking N. $25^{\circ}$ to $30^{\circ} \mathrm{W}$., dipping $30^{\circ} \mathrm{W}$., forms the east wall, recurs 100 feet west, and has some parallel subjoints; (b), discontinuous, strikes N. $5^{\circ}$ W., dips $65^{\circ} \mathrm{E}$. to $90^{\circ}$, and is spaced 100 feet; (c), discontinuous, strikes N. $75^{\circ} \mathrm{E}$., is vertical, and is spaced 2 to 50 feet. The rift is reported as horizontal and marked, and the grain as vertical with N. $70^{\circ} \mathrm{E}$. course. Biotitic knots are up to 2 inches across. There is little or no rusty stain below the top sheet.

The plant consists of a derrick and hoisting engine, an air compressor (capacity 100 to 200 cubic feet of air per minute), two large rock drills, 'and three air plug drills.

Transportation is by cart $5 \frac{1}{2}$ miles to rail at Concord.

The product is used for rough and cut monuments, and finds a. market mostly in the West.

NEWARK.

The Bugbee, Alexander \& Packer prospect is in the eastern part of Newark, on the west side of a ridge between Center Pond on the west and the East Branch of the Passumpsic on the east. This ridge lies north of Burke Mountain and southeast of Ball Hill. There is a marked east-west sag in the ridge. The prospect is a little north of the sag on a gently-sloping bench below the steeper part of the ridge and 363 feet above Center Pond, about east-southeast from its south end. (See map, fig. 9.) The intending operators are E. H. Bugbee and W. S. Alexander, of Barre, and H. D. Packer, of Newark, Vt.

The granite (specimen D, XXIX, 74, b), "Newark pink," is a biotite granite of light pinkish gray color and of coarse, even-grained texture, with feldspars up to 0.8 inch and mica to 0.15 inch. Its constituents, in descending order of abundance, are: Light pinkish gray potash feldspar (orthoclase and microcline), some of it intergrown with soda-lime feldspar or with inclusions of it, slightly kaolinized; medium smoky quartz with cavities in sheets; cream-colored, in places slightly greenish gray, striated soda-lime feldspar (albite to oligoclase-albite), much kaolinized, and with some white mica and carbonate; biotite (black mica), some of it chloritized. Accessory minerals are magnetite, pyrite, titanite, and allanite. Secondary minerals are kaolin, a white mica, epidote, and calcite.

4782-Bull. 404-09-3 
An estimate of the mineral percentages by the Rosiwal method, with a mesh of 0.6 inch and total linear length of 46 inches, yields these results:

Estimated mineral percentages in granite at Newark.

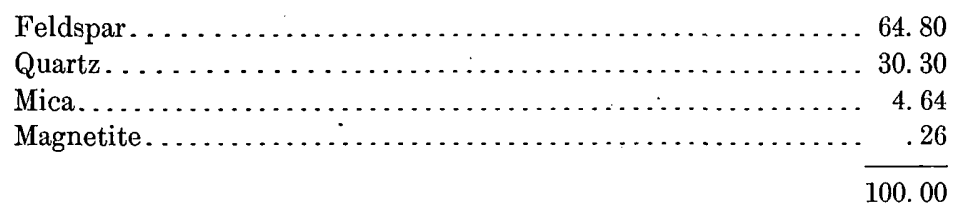

The average diameters of the particles obtained from the same calculation are: Feldspars (adding 20 per cent to the number as an estimate of the uncounted soda-lime particles), 0.162 inch; quartz, 0.106 inch; mica, 0.0406 inch. Average diameter of all particles, 0.123 inch.

The rock effervesce sslightly with cold dilute muriatic acid. W. T. Schaller, chemist, of the United States Geological Survey, finds that it contains 0.23 per cent of $\mathrm{CaO}$ (lime) soluble in warm dilute acetic acid (10 per cent), which indicates a content of 0.4 per cent of $\mathrm{CaCO}_{3}$ (lime carbonate, calcite), the presence of which mineral is also shown by the microscope.

The contrasts in this granite are chiefly between the smoky quartz and the combined feldspars. It has very sparse porphyritic feldspars up to 1.5 by 0.5 inches, but these are hardly numerous enough to impart to it a technically porphyritic texture. The polished face shows magnetite in minute particles and very few of pyrite. The polish is fairly good, the mica particles, although somewhat large, not being very abundant.

The sheets on the steeper, higher part of the ridge 110 feet above the bench carrying the outcrop sampled, are from 3 to 6 feet thick and not far from horizontal. Joints (a) strike N. $30^{\circ}$ E., dip $70^{\circ} \mathrm{W}$.; (b) strike N. $5^{\circ} \mathrm{W}$. and are vertical. The rift is possibly N. $85^{\circ} \mathrm{E}$. and vertical. The granite for a thickness of 110 feet and presumably to the top of the ridge is the same as that described.

The nearest railroad is 8 miles away.

RYEGATE.

TOPOGRAPHY.

The Ryegate quarries are on the southwest and northeast sides of Blue Mountain, a ridge with a northwest-southeast trend situated about 5 miles west of Connecticut River in the east-central part of the town. (See maps, figs. 1 and 10.) 
GENERAL GEOLOGY.

A mica schist crops out in the village of South Ryegate with a very steep dip, and appears to continue 3 miles north onto a bench on the southwest side of Blue Mountain and 770 to 800 feet above the village. The granite extends from the back or northeast part of the bench to the top of the ridge. At a point about 770 feet above the village the foliation and bedding of the schist strike N. $50^{\circ} \mathrm{W}$. and dip $55^{\circ} \mathrm{NE}$. In places the schist is coarse and speckled, but with it is interbedded a very quartzose mica slate (quartz-biotite-muscovite-epidote).

DESCRIPTION OF RYEGATE GRANITE.

The granites of Blue Mountain are quartz monzonites and biotite granites of light and medium more or less bluish gray color and of

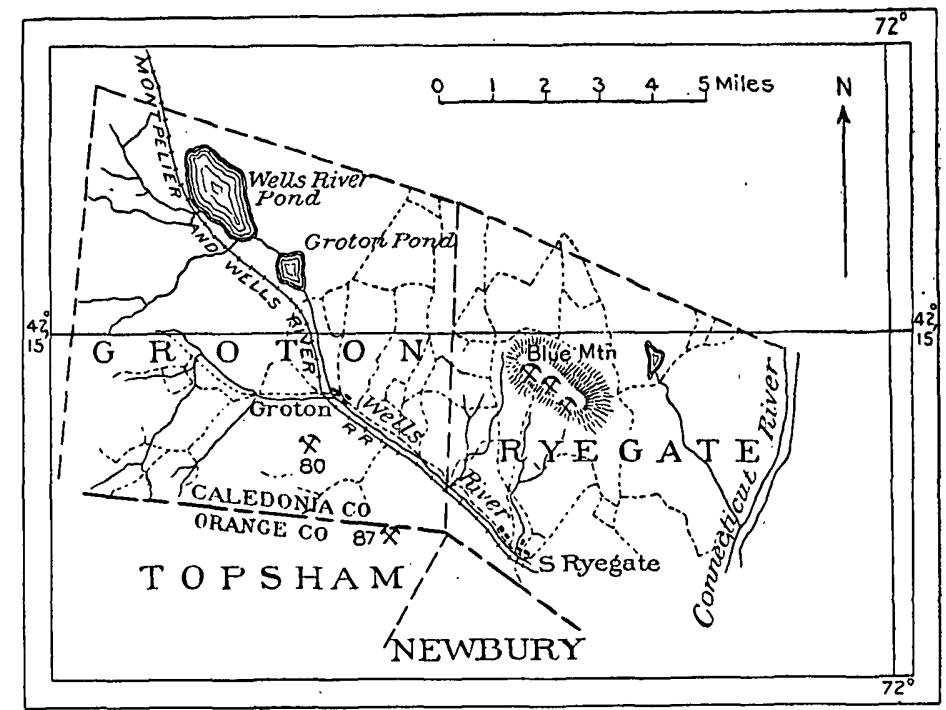

Figure 10.-Map of Ryegate, Groton, and part of Topsham, from Beers's Atlas. Quarries: 80, Benzie; 87, Ricker.

medium, very rarely fine to medium, even-grained texture, and are used chiefly for rough or hammered monuments. All the quartz monzonites of Ryegate ought to cut light.

\section{GEOLOGY OF RYEGATE QUARRIES.}

The inclusions of schist in "Ryegate granite" have already been described on page 19 and shown in Plate II, $B$, at the right. The sheets, ranging from 6 inches to 12 feet thick, are in places horizontal and in others dip from $5^{\circ}$ to $25^{\circ} \mathrm{S} .25^{\circ}, 45^{\circ}, 60^{\circ} \mathrm{W}$., also gently $\mathrm{S}$. and S. $45^{\circ} \mathrm{E}$., on the southwest side of the mountain. Their relation to that slope of the mountain is apparent at the Frazer quarry and on the ridge northeast of the Italian quarry for some 300 feet above it; but at the Rosa quarry, on the other side of the axis of the ridge, the 
sheets range from horizontal to $10^{\circ} \mathrm{E}$., thus indicating a broad anticlinal sheet structure. There are four sets of joints or two sets, each with its complementary one. The strikes are N. $70^{\circ}$ to $90^{\circ}$ W., N. $5^{\circ}$ E., N. $50^{\circ}$ W., and N. $30^{\circ}$ E. The flow structure, shown by biotitic streaks and planes, strikes N. $70^{\circ} \mathrm{W}$., and dips $20^{\circ}$ to $25^{\circ} \mathrm{N} .20^{\circ} \mathrm{E}$. The rift is reported as vertical with north-south or N. $55^{\circ} \mathrm{E}$. course, and the grain as horizontal. A 22 -inch basic dike crosses the granite on the northeast side with a N. $65^{\circ} \mathrm{W}$. course. The granite for a foot on either, side of it has subjoints one-half to 3 inches apart parallel to the dike. Small pegmatite dikes have N. $50^{\circ} \mathrm{W}$. and N. $15^{\circ} \mathrm{E}$. courses. The delimonitization of the rusty stain on underside of sheets has been noticed on page 26 .

GIBSON QUARRY.

The Gibson quarry is on the southwest side of Blue Mountain, 940 feet above the village of South Ryegate. Operator, Ryegate Granite Works, South Ryegate, Vt.

The granite (specimen D, XXIX, $\overline{81}$, a, from upper sheets) is a quartz monzonite of light to medium gray shade and medium, evengrained texture with feldspars up to 0.4 inch and mica to 0.1 inch. Its constituents, in descending order of abundance, are: Very light smoky quartz with fluidal and other cavities in sheets and a set of cracks parallel thereto, also with traces of another set of sheets at right angles to these; milk-white soda-lime feldspar (oligoclase) slightly kaolinized with a little white mica and epidote, some of it intergrown with quartz in vermicular structure; bluish potash feldspar (microcline, also orthoclase) similarly intergrown; biotite (black mica) and a little muscovite or bleached biotite. Accessory, titanite, zircon crystals, apatite, and pyrite. Secondary, epidote, kaolin, and white mica.

The rock does not effervesce with cold dilute muriatic acid. Its contrasts are weak.

The quarry, opened in 1906, is about 200 feet square and from 2 to 4 feet deep.

The sheets, from 6 inches to 4 feet thick, dip $15^{\circ} \mathrm{S} .25^{\circ} \mathrm{W}$. and are normal. There is but one set of joints, which strike east-west, and are vertical, at irregular intervals, and discontinuous. The rift is reported as vertical north-south and the grain as horizontal. The flow structure (biotitic streaks) strikes N. $70^{\circ}$ W. and dips $20^{\circ} \mathrm{N}$. $20^{\circ} \mathrm{E}$. A schist inclusion measures 12 by 8 inches. Small vertical pegmatite dikes strike N. $15^{\circ} \mathrm{E}$.

The plant consists of a derrick, hoisting engine, two air compressors, a steam drill, and two air-plug drills.

Transportation is by cartage 3 miles to cutting sheds at South Ryegate, 940 feet lower. 
The product is used for monuments and bases, and to some extent for building.

\section{MORRISON QUARRY.}

The Morrison quarry is on the southwest side of Blue Mountain, in Ryegate, about 940 feet above the village of South Ryegate and about 700 feet southeast of the Gibson quarry. Operators, D. A. Morrison \& Co., South Ryegate, Vt.

The granite (specimen $\mathrm{D}, \mathrm{XXIX}, \overline{8} \overline{2}, \mathrm{~b}$ ) is a quartz monzonite of medium gray shade and medium, even-grained texture, with feldspars up to 0.4 inch and mica to 0.2 inch. Its constituents, in descending order of abundance, are: Very light smoky quartz with hair-like crystals of rutile and cavities in sheets in two rectangular directions and cracks parallel thereto; milk-white soda-lime feldspar (oligoclase), somewhat kaolinized, with some white mica and rarely epidote, also intergrown with quartz in vermicular structure; bluish potash feldspar (microcline and orthoclase); intergrown with quartz in the same way; biotite (black mica); and a little muscovite or bleached biotite. Accessory: Zircon, apatite, rutile. Secondary: Kaolin, epidote, a white mica, and calcite, as shown also by muriatic acid test.

This stone is identical with that of the Gibson quarry, but its contrasts are a little sharper, as the quarry had got down to thicker sheets. Although the contrasts are feeble the smoky quartz is somewhat conspicuous.

The quarry, opened in 1900, measures about 400 by 200 feet, with an average depth of 20 feet.

The sheets, from 1 to 5 feet thick, dip very gently south and southeast. There are two sets of joints: (a), striking N. $85^{\circ} \mathrm{E}$., dipping $70^{\circ} \mathrm{S}$., forms a heading on the north side; (b), striking N. $30^{\circ} \mathrm{E}$., dipping $75^{\circ} \mathrm{N} .30^{\circ} \mathrm{W}$., is discontinuous and spaced very irregularly. The rift is reported as vertical north-south, and the grain as horizontal. Schist inclusions measuring 3 feet by 1 foot and 8 by 4 feet are described on pages 19,20. (See also PI. II, $B$, at the right.) Small pegmatite veins, "tight sets," are bordered with large biotitic spots and muscovite flakes.

The plant consists of two horse derricks.

Transportation is by cartage 3 miles to South Ryegate, 940 feet lower.

The product is used for bases and hammered monuments.

ITALIAN QUARRX.

The Italian quarry is on the southwest side of Blue Mountain, 940 feet above the village of South Ryegate and about 400 feet N. $60^{\circ} \mathrm{W}$. from the Gibson quarry. Operator, Caledonia Quarry Company, South Ryegate, Vt. 
The granite is a quartz monzonite of light to medium gray shade and medium, even-grained texture, identical with that of the Morrison and Gibson quarries.

The quarry, opened in May, 1907, measures about 250 by 100 feet and from 1 to 5 feet in depth.

The sheets, from 10 inches to 5 feet thick, dip $20^{\circ} \mathrm{W}$. Only one set of joints, which strikes N. $50^{\circ} \mathrm{W}$. and dips $30^{\circ} \mathrm{E}$., and is spaced 50 feet. The rift is reported as vertical with N. $55^{\circ}$ E. course and the grain as horizontal, and both as equal. Two pegmatite dikes $\left(0.25\right.$ and 2.5 inches thick) strike N. $50^{\circ}$ W. and dip $45^{\circ}$ N. $50^{\circ} \mathrm{E}$. There is a biotitic segregation 3 inches by 1 inch. There is little or no rusty stain on sheet surfaces.

The plant consists of one horse derrick.

The product is carted 3 miles to South Ryegate, and is used for bases and hammered monuments.

TUPPER QUARRY.

The Tupper quarry is on the southwest side of Blue Mountain, about 600 feet S. $20^{\circ} \mathrm{E}$. of the Italian quarry and from 940 to 960 feet above South Ryegate. Operators, W. S. Tupper \& Co., South Ryegate.

The granite is a quartz monzonite of light to medium gray shade and medium texture, identical with that of the Morrison, Gibson, and Italian quarries.

The quarry, opened in May, 1907, measures about 100 by 50 feet and 3 feet in depth.

The sheets, from 1 to 3 feet thick, dip $5^{\circ} \mathrm{S} .60^{\circ} \mathrm{W}$. There is only one joint, which strikes N. $40^{\circ} \mathrm{W}$. and dips $35^{\circ} \mathrm{S} .40^{\circ} \mathrm{E}$. Little pegmatite dikes up to 0.75 inch wide occur at irregular intervals, striking N. $50^{\circ} \mathrm{W}$. and dipping $30^{\circ} \mathrm{N} .50^{\circ} \mathrm{E}$.

There is a compressive east-west strain.

The plant comprises one horse derrick.

Transportation is by cartage 3 miles to South Ryegate, 950 feet lower.

The product is used for bases and hammered monuments.

ROSA QUARRY.

The Rosa quarry is on the northeast side of a southeast spur of Blue Mountain, which is about 300 feet below its top and in line with its main axis. This quarry is about one-third mile by road from the Frazer quarry and about 1,100 feet above South Ryegate. Operator, Vermont Gray Granite Company, South Ryegate, Vt.

The granite is of two kinds. The first is fine gray (specimen $\mathrm{D}$, XXIX, $\overline{79}, a)$, a biotite granite of medium gray shade and of fine inclining to medium, even-grained texture, with feldspars up to 
0.2 inch and mica to 0.1 inch. Its general shade is a trifle darker than that of the quartz monzonite of the Morrison quarry. Its constituents, in descending order of abundance, are translucent to very light bluish gray potash feldspar (orthoclase and microcline); light smoky quartz with hair-like crystals of rutile, and fluidal and other cavities in sheets with cracks parallel thereto; whitish soda-lime feldspar (oligoclase) slightly kaolinized, micacized, and epidotized, in places intergrown with quartz in vermicular structure; biotite (black mica), a little muscovite or bleached biotite. Accessory: Apatite, zircon crystals, titanite. Secondary: Kaolin, a white mica, epidote, limonite.

W. T. Schaller, chemist, of the United States Geological Survey, finds that this stone contains 0.03 per cent of $\mathrm{CaO}$ (lime) soluble in warm dilute (10 per cent) acetic acid, which indicates the presence of 0.05 per cent of $\mathrm{CaCO}_{3}$ (lime carbonate). No carbonate was detected in thin section nor any effervescence with cold dilute muriatic acid.

-The fineness of the texture of this stone precludes mineral contrasts.

The other granite (specimen D, XXIX, $\overline{79}, b$ ), "coarse gray," is a biotite granite of medium bluish-gray shade, and medium, evengrained texture, with feldspars up to 0.3 inch and mica to 0.15 inch. This is also a trifle darker than that of the Morrison quarry. Its constituents, in descending order of abundance, are: Translucent bluish-gray potash feldspar (microcline and orthoclase); light smoky quartz with fluidal and other cavities in sheets, with cracks parallel to or coinciding with them; milk-white soda-lime feldspar (oligoclase) somewhat kaolinized, a little micacized, with some carbonate and less epidote; biotite (black mica), some of it bleached. Accessory: Apatite in slender prisms, allanite. Secondary: Kaolin, calcite, white mica, epidote. The stone effervesces with cold dilute muriatic acid.

Its contrasts are stronger than those of the quartz monzonites of the Morrison and Gibson quarries. It contains more biotite.

The quarry, opened in 1906, measures about 150 by 7.5 feet and from 10 to 25 feet in dépth.

The sheets, from 1 to 10 feet thick, are horizontal or dip to $10^{\circ} \mathrm{E}$. There are three sets of joints: (a), striking east-west, dipping $65^{\circ} \mathrm{S}$, forms a 3-foot-wide heading on the north; (b), striking N. $70^{\circ}$ to $80^{\circ}$ W., dipping $40^{\circ} \mathrm{N} .10^{\circ}$ to $20^{\circ} \mathrm{E}$., is spaced 1 to 25 feet, coated with epidote and slickensided; (c), striking N. $5^{\circ}$ E., vertical, one only. The rift is reported as vertical with N. $60^{\circ} \mathrm{E}$. course, and the grain as horizontal. The fine granite (specimen $\overline{79}$, a) occurs only north of heading (a). On the south edge of the quarry a vertical basic dike, 22 inches thick, strikes N. $65^{\circ}$ E. (See page 36.) Rusty stain does not exceed 2 inches. In a surface sheet it measures an inch. 
The plant includes, at the quarry, a 45-ton derrick, a hoisting engine, a small air compressor for two air plug drills, a large steam rock drill, and a steam pump, besides at the cutting shed a hand derrick and a 10-ton overhead crane.

The product is carted nearly 4 miles to the cutting shed at South Ryegate, and is used for hammered and rock-faced monuments and bases.

FRAZER QUARRY.

The Frazer quarry (formerly known as Hall's) is on the southwest side of the southeast spur of Blue Mountain, about 950 feet above South Ryegate. It was not in operation in 1907. The owner is Mrs. Margaret Hinchey, Hydeville, Vt.

The granite (specimen D, XXIX, $\overline{8} \overline{5}, \mathrm{~b}$ ), gray granite, is a quartz monzonite of light to medium gray shade and of medium inclining to coarse, even-grained texture, with feldspars up to 0.4 inch and mica to 0.2 inch. Its constituents, in descending order of abundance, are: Light smoky quartz with hair-like crystals of rutile and cavities in sheets, with a set of cracks parallel to them; milk-white soda-lime feldspar (oligoclase) somewhat kaolinized, with some small plates of white mica and a few grains of epidote. In places it is intergrown with quartz in vermicular structure; translucent bluish potash feldspar (microcline), some of it slightly kaolinized; biotite (black mica) and a little muscovite. Accessory: Titanite, allanite, apatite, zircon. Secondary: Kaolin, a white mica, epidote, and carbonate shown by slight effervescence with cold dilute muriatic acid.

While the general shade of this stone differs but little from that of the Morrison and Gibson quarries, the contrasts between its minerals are much more marked.

The quarry measures about 300 feet square and from 5 to 20 feet in depth.

The sheets are normal and from 1 to 12 feet thick, dipping $25^{\circ} \mathrm{SW}$. There is but one joint (southwest side), striking N. $70^{\circ}$. W., dipping $35^{\circ} \mathrm{N} .20^{\circ} \mathrm{E}$. A flow structure of biotitic streaks and sheets strikes N. $70^{\circ} \mathrm{W}$., and $\operatorname{dips} 45^{\circ} \mathrm{N} .20^{\circ} \mathrm{E}$. In the west half of quarry this is so prominent as probably to detract from the value of the stone. Rusty stain along sheet surfaces is up to 3 inches thick. (See, further, p. 26.)

The plant comprises two horse derricks.

The product must be carted $3 \frac{1}{2}$ miles to South Ryegate.

GROTON.

The Benzie quarry is in Groton about a mile S. $25^{\circ} \mathrm{W}$. from the Wells River Bridge at Groton and 300 feet above it, and about $4 \frac{1}{2}$ miles S. $85^{\circ} \mathrm{W}$. from Blue Mountain in Ryegate. (See fig. 10.) Operators, McCrae, Benzie \& Co., Groton, Vt. 
The granite (specimen D, XXIX, $\overline{8} \overline{0}$, a), "Vermont blue," is a quartz monzonite of medium, very bluish gray color and evengrained medium inclining to fine texture. Its constituents, in descending order of abundance, are: Clear, colorless to very light smoky or very light bluish quartz, with few cavities and brightly polarizing rift and grain cracks; light-bluish translucent soda-lime feldspar (oligoclase), somewhat kaolinized and with white fibrous mica, also a white mica in small scales, and some calcite; a little clear potash feldspar (microcline, also orthoclase), with inclusions of oligoclase, quartz, and biotite; biotite (black mica); and a little muscovite or bleached biotite. Some of the feldspars are minutely intergrown with quartz in vermicular structure. Accessory: Titanite, pyrite, zircon crystals, apatite, allanite. Secondary: Kaolin, a white mica, calcite, leucoxene. The granite effervesces with cold dilute muriatic acid.

This stone is brilliant and markedly bluish, but its mineral contrasts are feeble owing to fineness of texture and similarity in shade of feldspar and quartz.

The quarry, opened in 1896 , measures about 200 by 175 feet and from 40 to 60 feet in depth.

The sheets are normal, from 1 to 10 feet thick, and range from the horizontal to a very low dip north and also east. There are three sets of joints: (A), striking N. $55^{\circ}$ E. and vertical, spaced 15 to 50 feet, forms a rusty heading on the west wall, with short vertical subjoints at right angles to it; (B), striking N. $50^{\circ} \mathrm{E}$. (diagonal to quarry), dipping $60^{\circ} \mathrm{S} .50^{\circ}$ E., discontinuous and at irregular intervals; (C), striking N. $20^{\circ} \mathrm{W}$. and vertical, discontinuous and rare. The rift is reported as horizontal and the grain as vertical, with N. $55^{\circ}$ E. course. There is a coarse "shake" structure in bands up to a foot thick parallel to the sheets, at points 25,40 , and 60 feet below the surface. ${ }^{a}$ There are biotitic masses on the west side parallel to joints (A), the course of which is also that of the grain, and thus also that of the flow. On the west wall is a dike of quartz monzonite (specimen $\mathrm{D}$, XXIX, $\overline{8} \overline{0}$, b) 5 feet thick, of medium bluish-gray color and very fine, even-grained texture, with feldspars up to 0.1 and mica mostly under 0.05 , exceptionally 0.1 inch. Its constituents are the same as those of the main granite. There are two dikes of similar quartz monzonite but of dark, slightly bluish-gray color and extremely fine texture, with feldspars up to 0.06 (exceptionally 0.1) and mica to 0.04 inch. These dikes are 6 and 2 inches thick, strike N. $5^{\circ}$ and $20^{\circ} \mathrm{E}$., and $\operatorname{dip} 70^{\circ} \mathrm{E}$. and $90^{\circ}$. Several pegmatite dikes from 1 to 6 inches thick cross the entire quarry, cutting the first granite dike, some striking N. $17^{\circ} \mathrm{W}$, others in various directions. There is also a 3 -inch diabase dike on the west wall. It contains porphyritic augite 
crystals, some of which have been replaced by quartz or calcite or chlorite. These structural features are shown in diagram in figure 11. A compressive strain is reported here as from all directions. Rusty stain is only an inch thick on sheets 10 feet below the surface.

The plant at the quarry consists of a 50-ton derrick, hoisting engine, steam pump, and large rock drill, to which were added in 1908 a 90 -foot derrick and an air compressor with a capacity of 130 cubic feet of air per minute, sufficient for two large rock drills and four air-plug drills. At the cutting shed there are two hand derricks, two steam derricks, an air compressor, two surfacers, 20 air hand tools, two steam engines, and three polishers.

The product is carted $1 \frac{1}{2}$ miles to the cutting shed at Groton. It is used for monuments and buildings. The fine stone of the granite dike is used for special orders and carved work. Examples are the

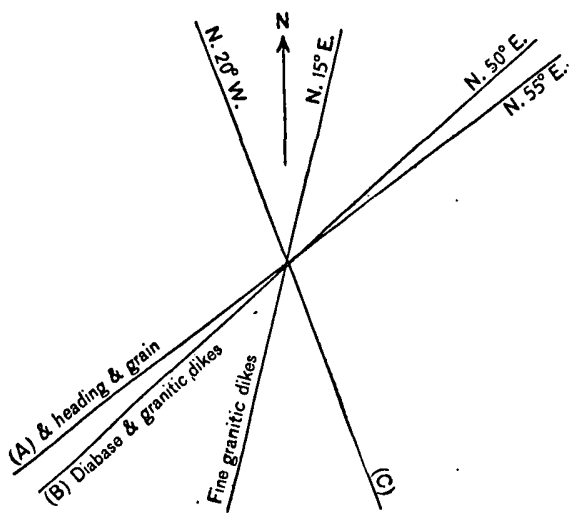

Figure 11.-Structure at Benzie quarry, Groton.

Davison monument at Woodsville, N. H., and the Dr. S. N. Eastman monumert at Groton, Vt.

\section{ORANGE COUNTY.}

The quarries of Orange County are in Williamstown, but as these closely adjoin those of Barre, as shown on the map (Pl. I); they will be considered in connection with the Barre quarries. (See pp. 85-87.) A quarry in Topsham and a prospect in Randolph properly belong here.

TOPSHAM.

Granite was formerly quarried at two points in Topsham. One was very near the village of South Ryegate, the other on Pine Mountain about south-southeast of Groton. ${ }^{a}$ Hitchcock and Hager's geologic map represents a granite area extending from Groton into Topsham, but it seems too far west. (See map, fig. 10.)

The Ricker quarry is in Topsham at the west foot of Pine Mountain, roughly about $5 \frac{1}{2}$ miles west-southwest of Blue Mountain, $2 \frac{1}{4}$ miles southeast of the Benzie quarry, and $2 \frac{3}{4}$ miles south-southeast of Groton and 490 feet above it. (See fig. 10.) Owner is Isaac N. Ricker, Groton, Vt.

The granite (specimen D, XXIX, $\overline{8} \overline{7}$, a), "Pine Mountain," is a quartz monzonite of medium bluish-gray color and medium, some-

a This last, here described, is probably the one referred to by the state geologist in 1900 as operated then by the Pine Mountain Granite Company. (See Perkins, G. H., Mineral resources of Vermont, 1899-1900, p. 75.) 
what even-grained texture with feldspar up to 0.4 inch and mica to 0.1 inch, but with sparse, clear, porphyritic feldspars, including all the other chief constituents. The stone is not quite so bluish as that of the Benzie quarry in Groton, nor do its feldspars seem to be as evenly distributed. Its constituents, in descending order of abundance, are clear colorless to very pale smoky quartz with cavities in intersecting sheets; bluish translucent to milk-white soda-lime feldspar (oligoclase) somewhat kaolinized and micacized, and with calcite; clear potash feldspar (microcline and orthoclase) inclosing oligoclase, quartz, and biotite; biotite (black mica); and a little muscovite or bleached biotite. Accessory: Titanite, allanite, apatite, zircon. Secondary: Kaolin, a white mica, calcite, zoisite. There is some intergrowth of feldspar and quartz. The stone effervesces with cold dilute muriatic acid.

The porphyritic clear feldspars enhance the brilliancy of the rough surface. Its contrasts are greater than those of the Benzie quarry stone, but there are minute rust spots on the long-exposed blocks about the quarry, the cause of which was not manifest.

The quarry is about 40 by 32 feet and the working face on the east is 20 feet high from the road and quarry level. It has been idle a number of years.

The sheets, from 5 to 12 feet thick at their widest parts, are normal and horizontal or inclined as high as $10^{\circ} \mathrm{N} .45^{\circ} \mathrm{W}$. There are two sets of joints: (a), striking N. $70^{\circ} \mathrm{E}$., vertical, forms the north wall, and a 25-foot heading north of it with joints 2 to 4 feet apart, and another on the south wall; (b), striking N. $40^{\circ}$ E. and dipping $55^{\circ} \mathrm{N} .45^{\circ} \mathrm{W}$., forms the east wall and recurs 10 feet east. The flow structure has a N. $35^{\circ}$ E. course. Vertical pegmatite dikes up to 1.5 inches thick strike N. $25^{\circ} \mathrm{W}$. Aplite dikes up to 1 inch thick strike N. $45^{\circ}$ and $55^{\circ} \mathrm{E}$.

The product was carted about 3 miles to rail at Groton, 490 feet lower.

\section{RANDOLPH.}

Beedle's prospect is in the west corner of the town of Randolph between the Bethel line and the west branch of White River, in school district 11, three-fourths of a mile west and southwest of the Vermont Central Railroad, which here describes a curve. It is on the farm of A. H. Beedle, of Randolph, Vt. (See fig. 24.) The particulars were obtained by Professor Perkins.

According to the state geologic map of 1861 this granite should be on the west side of the western belt of "clay slate," but no granite is shown on the map in this town.

The granite (specimen D, XXIX, 100, a, and b), fine white granite, is a quartz monzonite of extremely light gray shade without any mica spots. It is lighter than "Dummerston white" but not as 
white as that of Bethel when the rough faces are compared, and its slight grayness has a tinge of green in it. Its texture is even-grained and fine with feldspars nearly all under 0.1 inch and none over 0.15 inch. Its constituents, in descending order of abundance, are: Milkwhite striated soda-lime feldspar (albite to oligoclase-albite), some of it intergrown with potash feldspar (microcline), the latter forming, however, but a small portion of the particle (the soda-lime feldspar is more or less kaolinized and micacized); colorless, clear quartz with fluidal and other cavities, rarely with hairlike crystals of rutile; very little separate potash feldspar (microcline) in minor particles; muscovite (white mica) in scales up to 0.37 millimeter. The accessory minerals are zircon, apatite, and rutile. No magnetite or pyrite was detected. The secondary minerals àre kaolin, a white mica, rather abundant epidote, and zoisite in irregular particles up to 0.5 millimeter, exceptionally 0.75 millimeter, accounting for the greenish tinge (this is really the fifth mineral in order of abundance); a little calcite and rare chlorite scales up to 0.22 , exceptionally 0.75 millimeter, reenforcing the greenish tinge.

An estimate of the mineral percentages made by applying the Rosiwal method to a camera lucida drawing of a thin section enlarged 40 diameters yields these results with a mesh of 1 inch and a total linear length of 34 inches.

Estimated mineral percentages in fine white granite of Randolph.

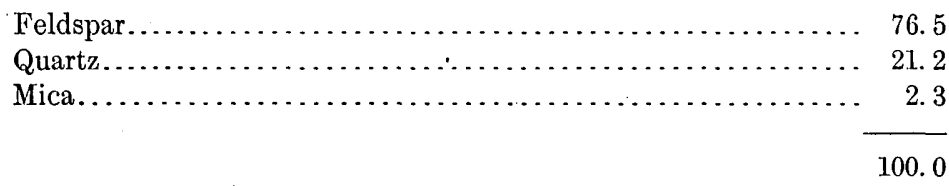

The average diameter of the particles obtained from the same calculation is $0.0049 \mathrm{inch}$; that of the feldspar, $0.0083 \mathrm{inch}$; of the quartz, $0.0032 \mathrm{inch}$; and of the mica, 0.0024 inch.

The stone effervesces slightly with cold dilute muriatic acid. W. T. Schaller, chemist, of the United States Geological Survey, finds that it contains 0.37 per cent of $\mathrm{CaO}$ (lime) soluble in warm dilute $(10$ per cent) acetic acid, which indicates a content of 0.66 per cent of $\mathrm{CaCO}_{3}$ (lime carbonate, calcite) which mineral also appears. in thin section.

The stone takes a high polish, as the absence of all but very minute mica plates implies. Being a quartz monzonite, and being also free from mica spots, it will probably hammer quite as white as the quartz monzonite from Bethel. The hand specimens show traces of rift or flow structure.

There are no data as to size of outcrop or as to structure. The principal opening is 60 by 30 feet. 
ORLEANS COUNTY.

NEWPOR'T GRANITE COMPANY'S QUARRY.

The Newport Granite Company's quarry is near the center of the town of Derby and about 4 miles roughly east of the city of Newport, on Lake Memphremagog. (See map, fig. 1.) Operator, George R. Farquharson, Newport, Vt.

The granite (specimen D, XXIX, 75, a), gray granite, is a quartz monzonite, with both biotite and muscovite, of light bluish-gray color and even-grained, medium inclined to fine texture with feldspars up to 0.25 and 0.3 inch, and mica to 0.15 inch: Its constituents, in descending order of abundance, are: Light smoky quartz with hairlike crystals of rutile, fluidal and other cavities in sheets with cracks parallel to and in places coinciding with them; clear to bluish milk-white striated soda-lime feldspar (oligoclase), mostly much kaolinized and somewhat micacized, also intergrown in places with quartz in vermicular structure; clear to translucent bluish potash feldspar (microcline and orthoclase) slightly kaolinized; biotite (black mica); muscovite (white mica). Accessory: Apatite, titanite, allanite, rutile. No magnetite or pyrite was detected. Secondary: kaolin, a white mica, and calcite from chemical test.

There is no effervescence with cold dilute muriatic acid, but W. T. Schaller, chemist, of the United States Geological Survey, finds that it contains 0.05 per cent of $\mathrm{CaO}$ (lime) soluble in warm, dilute (10 per cent) acetic acid, which indicates the presence of nearly 0.09 per cent of $\mathrm{CaCO}_{3}$ (lime carbonate, calcite), which is very slight indeed.

The shade of this stone is between that of "light Barre" and that of the granite of Hallowell, Me. It has more black mica than "light Barre" and stronger contrasts. These are bright between the black mica, the feldspar, and an intermediate shade formed by the muscovite and quartz together. The stone should hammer lighter than a biotite-muscovite granite. ${ }^{a}$

The quarry; opened about 1880 , measures about 300 feet N. $45^{\circ} \mathrm{W}$. by 250 feet $\mathrm{N} .55^{\circ} \mathrm{E}$, and averages 20 feet in depth.

The sheets, from 3 to 18 feet thick, dip $20^{\circ} \mathrm{S} .55^{\circ} \mathrm{W}$. They "grow together," that is, sheet structure is undeveloped in the western part of the quarry, making masses 22 to 25 feet thick. One set of vertical joints, discontinuous, strikes N. $55^{\circ} \mathrm{W}$., is spaced 10,30 , and 100 feet and forms a heading on the north wall. At the northeast corner there is a trace of a transverse set. The rift is reported as horizontal and the grain as vertical with N. $55^{\circ} \mathrm{E}$. course. Both are marked. Flow structure, consisting of muscovitic and biotitic bands, is vertical with $\mathrm{N} .50^{\circ} \mathrm{E}$. course. The muscovite scales in these bands

$a$ See a recent reference to this stone and quarry in Richardson, C. H., The geology of Newport, Troy, and Coventry: Rept. State Geologist of Vermont, 1908, p. 280, and Pl. LVIII. 
measure up to 0.25 inch. There are very irregular biotitic surfaces in the eastern part of quarry, resembling tree roots in form. Associated with them are nonmicaceous lighter tortuous bands. These are presumably irregularities in the flow structure. A "shake structure" up to 5 inches thick occurs on some sheet surfaces, and the rock there is passing into sand. The contact here has already been alluded to on page 13. A north-south compressive strain is reported by the foreman. There is no "sap" on the sheet surfaces.

The plant consists of one 40-ton and two 20-ton derricks, three hoisting engines, an air compressor (capacity 292 cubic feet of air per minute), four large rock drills, fifteen air plug drills, and three steam pumps.

The product is carted 4 miles to the railroad at Newport. It is used for monuments and buildings, and finds its chief market in the West. Specimen: The prison ship martyrs' monument in Fort Greene Park, Brooklyn, N. Y. Height, 150 feet, shaft 18 feet in diameter at base and 14 feet at top.

PARMENTER QUARRY.

The Parmenter quarry, visited in 1909, is in Derby Township, near Beebe Plain, close to the Canada line and about a mile east of Lake Memphremagog. It is not shown on figure 1. Operator, W. H. Parmenter, North Derby, Vt.

The granite (specimen D. XXX, 72, a), light granite, not examined microscopically, is either a biotite granite or a biotite-quartz monzonite of very light gray shade and even-grained medium texture, with feldspars up to 0.3 and micas to 0.2 inch. Its constituents are slightly bluish milk-white feldspars, light-smoky quartz, and biotite (black mica). It effervesces slightly with acid test.

The general shade of this granite is lighter than that of North Jay and darker than that of Bethel, or nearly the same as that of "West Dummerston white" but with more conspicuous black micas. deep.

The quarry, recently opened, is 40 by 25 feet in area and 10 feet

The sheets, 2 to 5 feet thick, are insufficiently exposed but appear to undulate horizontally. Joints (a) strike N. $50^{\circ} \mathrm{W}$, dip $60^{\circ} \mathrm{SW}$., are spaced 10 to over 20 feet. Joints (b) strike N. $30^{\circ}$ E., dip $80^{\circ}$ S. $60^{\circ}$ E., one only. The rift is reported as horizontal and grain vertical with $\mathrm{N} .50^{\circ} \mathrm{E}$. course. In a larger quarry on the Canadian side, a few hundred feet from the other, worked by the same operator, granite of the same mass and character has sheets 10 feet thick and a flow structure with N. $60^{\circ} \mathrm{W}$. course.

The plant consists of one hand derrick. 
The product is carted half a mile to a siding on the Canadian Pacific Railway at North Derby and is used for hammered monuments or bases.

\section{WASHINGTON COUNTY.}

The quarries are in Barre, Cabot, Calais, and Woodbury. Those of Williamstown, in Orange County, will be described in connection with those of Barre, as they belong to the same group and their granite is continuous and identical.

\section{BARRE AND WILLIAMSTOWN.}

\section{TOPOGRAPHY.}

The city of Barre lies about 5 miles southeast of Montpelier (see fig. 1), and the Barre quarries are 3 miles farther southeast, near the southeast corner of the township of Barre, and a few of them are in Williamstown, in Orange County, which adjoins Barre on the south. The city of Barre lies on Stephens Brook, a tributary of the Winooski, which empties into Lake Champlain. About half a mile south-

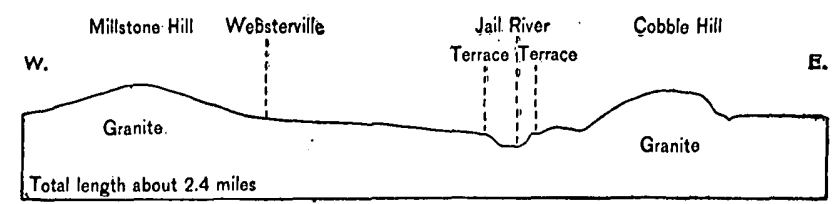

Figure 12.-General topographic section through granite mass of Barre. Scale, 194 feet to 0.1 inch

southeast of Barre City this brook receives a tributary from the southeast, known as Jail River. Some $2 \frac{1}{2}$ miles southeast of the city this river flows through a canyon-like gorge between flat-topped masses of sand, clay, and bowlders over 200 feet thick. A little north of Jail River at this point a roundish granite mass, known as Cobble Hill, rises to a height of 1,100 feet, by aneroid, above the city; and 2 miles about southwest of this hill and a little south of the river another granite mass, known as Millstone Hill, rises to a height of 1,200 feet, by aneroid, above the city. Fifty-six quarries are grouped about these two granite masses, and of these 52 are about Millstone Hill. The section (fig. 12) will serve to convey a general idea of the surface features described. The locations and designations of the Millstone Hill quarries are given in Plate I.

GENERAI GEOLOGY.

The geology of the granite area of Barre was last treated by George I. Finlay. ${ }^{a}$

a The granite area of Barre, Vt.: Rept. Vermont State Geologist (3), 1902, pp. 46-59, and Pl, IV, 
His map shows that he regards the two granite hills as parts of one granite area with a north-northeast trend over 4 miles long by $1 \frac{1}{2}$ wide, surrounded by slate and schist. Its representation on the state geologic map of 1861 is not far different. The writer's time was too short to enable him to trace the boundaries of the granite and schist, nor was a map suitable for such purpose available. Finlay represents a schist tongue crossing Millstone Hill diagonally from northwest to southeast, and Cobble Hill as all granite; but the writer found schist on the north side of the top of the Cobble, without, however, determining its northern limit. The schist capping also crops out at Jones Brothers' and Barclay's quarries, and near the Marr \& Gordon quarry of the Consolidated Company (Nos. 10, 12, 26 in PI. I), and in Websterville. Some of these schist masses are probably lesser bands still lying on the Granite, which Finlay states were too small to enter on his small-scale map.. The strike of the foliation of the schist about the quarries varies from $\mathrm{N}$. to N. $60^{\circ} \mathrm{E}$., and the dip is steep west or $90^{\circ}$. In a group of quarries southsoutheast of Millstone Hill it strikes uniformly from N. $30^{\circ}$ to $35^{\circ} \mathrm{E}$.

These are the chief geologic features of the Barre district. Four formations are represented: (1) The schist, a metamorphosed marine argillaceous and calcareous sediment of unknown thickness, underlying the city and surrounding the granite area; (2) the granite, of igneous origin, intruded in the schist and forming two domes, 2 miles apart, with an intervening depression, which in consequence of the erosion of the schist now project through it; (3) certain dark basic dikes of later date cutting the granite and the schist also; (4) finally, masses of sand, clay, and bowlders, over 200 feet thick in the hollow between the domes, of glacial origin, overlying the schist and part of the granite.

The geologic age of schist and granite have been discussed on page 13 , and their probable history was sketched on page 16 .

As many as seven different sets of surface forms have existed here: (1) The original surface of the sediments of clay and sand before their emergence from the sea; (2) the surface of those sediments after their metamorphism into schist and before the granitic intrusion; (3) the surface of the schist mass as modified by the granitic intrusion; (4) the surface of the schist and granite masses which resulted from the long period of preglacial erosion; (5) the original surface of the superimposed glacial deposits; (6) the surface of the glacial deposits as modified by glacial lake levels; (7) the surfaces produced in both unmodified and modified glacial deposits by postglacial streams. It is assumed in this outline that any modifications of the eroded rock surface by the glacier were unimportant, and the surface of the ice sheet itself has not been considered. 


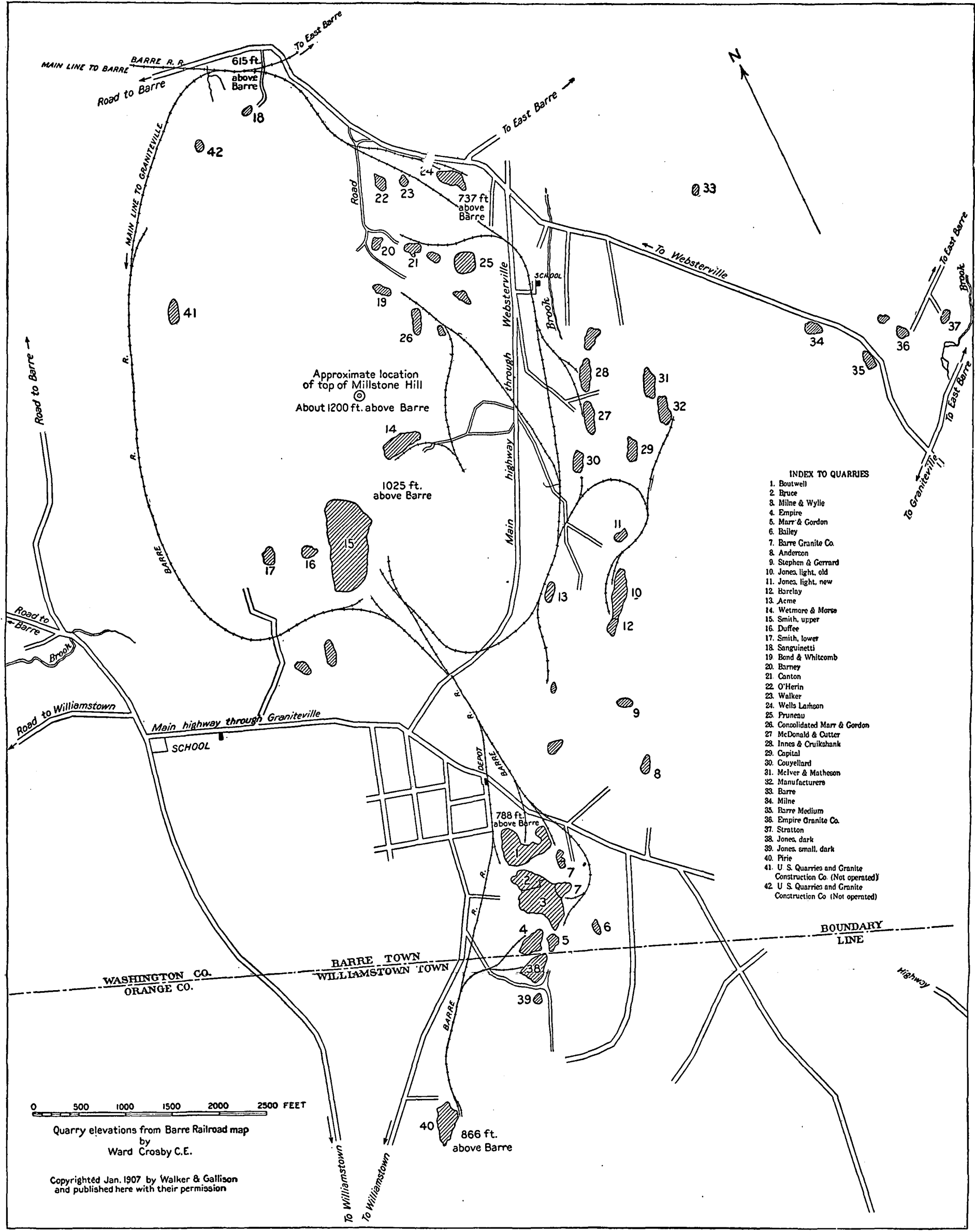

MAP OF THE "BARRE QUARRIES" ABOUT MILLSTONE HILL, in BARRE aND WILLIAMSTOWN, VT. 
The present surface is evidently of complex origin. Parts of it were formed under (4), (5), (6), and (7). Wherever no glacial deposits were formed or wherever they were afterward removed we have the surface (4). In the gorge between Millstone and Cobble Hills, as shown in figure 12 , the coarse and fine glacial deposits have a nearly level surface, which is probably due to terracing by a glacial lake (6). These opposite terraces may have been continuous, but the gorge itself is partly or entirely the result of the cutting of the terraced glacial deposits (7). In places the processes of (7) have exposed the schist surface formed by (5) and made small inroads upon it.

The schist of Barre varies much in character. A few observations were made and specimens collected. In many places it contains lenses and beds of calcareous quartzose rock. On Brook avenue, in the northwest part of the city, a mass of this dips $30^{\circ}$ to $40^{\circ}$ about southwest, but with traces of plicated bedding in the opposite direction. It is a very dark gray fine-grained quartzose crystalline limestone. The sections show quartz particles to 0.24 millimeter in a cement of calcite plates with rare muscovite scales and many minute black (carbonaceous?) particles. At the other end of the city near the covered bridge over Jail River it is a very fine black roofing slate with minute secondary plications, and spangled with black tabular crystals up to 0.1 inch across, probably of ilmenite. The microscope shows it to be a muscovite-quartz slate with a little biotite and chlorite. Part of the outcrop is a muscovite schist with quartz and calcite and spangled with biotite scales lying across the schistosity, also with rhombic plates of chlorite and ilmenite up to $0.2 \mathrm{inch}$. Near quarry No. 26 (Pl. I) a 3 -foot thick granitic dike crosses the schist. This proves to be a light-gray fine-textured porphyritic biotite granite differing from "Barre granite" mainly in texture. There are here and there within the granite area strips of schist which are parts of the original capping left by erosion. There are also blocks of schist within the granite (inclusions) which probably dropped into the rising semiliquid granite from the under side of the fractured capping. These are described more fully on pages 18-19.

The pegmatite and aplite dikes which traverse the granite belong to a later stage of the period of intrusion, but after the consolidation of the granite. The basic dikes described later (p. 56) and referred to by Finlay ${ }^{a}$. belong to a still later date. He describes as camptonite a 5-foot thick dike which crosses the schist just south of Barre on the road to South Barre, and he illustrates its spheroidal weathering. 
"BARRE GRANITE."

"Barre granite" is known commercially as "dark Barre," "medium Barre," and "light Barre," with some exceptional "very dark Barre" and "white Barre." It appears to be everywhere a biotite granite in which the orthoclase is considerably kaolinized and micacized, but the microcline is fresh. 'The dark stone of the Milne \& Wylie quarry and of the Jones dark quarry shows such a contrast between its hammered and polished faces as to indicate that the amount of soda-lime feldspar in it is larger than it is in the other granites of Barre or in biotite granites generally, and the thin sections show considerable plagioclase altered like the orthoclase. But Whitman Cross, of the United States Geological Survey, found a specimen of "dark Barre" quarried by Wells, Lamson \& Co. to be a typical biotite-muscovite granite in which the amount of plagioclase (soda-lime feldspar) was so small as to place it among the accessory constituents. (See p. 76. ${ }^{a}$ )

The various shade designations of this granite are due in part to the different degree of kaolinization and micacization of its orthoclase feldspar, causing it to range from a translucent bluish gray to milkwhite, and in part also to the varying content of black mica. Technically its shades are here defined as: (1) Very light gray (Wheaton quarry), equivalent to that of North Jay, Me.; (2) light inclining to medium, slightly bluish gray (Jones light quarry), between that of North Jay and of Hallowell, Me.; (3) light medium bluish gray (Smith upper quarry), between that of Hallowell, Me., and Concord, N. H.; (4) medium bluish gray (Duffee quarry), a trifle darker than "Concord granite;" (5) dark inclining to medium bluish gray (Bruce quarry); (6) dark bluish gray (Marr \& Gordon quarry); (7) very dark bluish gray (Marr \& Gordon quarry knots), equivalent to "dark Quincy." The chief product consists of (3), (4), and (5). The dark shades occur near the Williamstown line, the light near the top of Millstone Hill on its south and southwest sides, and also about threefifths of a mile south-southwest of the top. The cause of this distribution is not evident.

Its texture ranges from fine to medium; that is, with feldspars up to 0.2 and 0.4 inch, generally, however, not exceeding 0.2 inch, few reaching 0.3 inch, so that it may be generally designated fine inclining to medium or medium inclining to fine. But the light granites of the Bond \& Whitcomb quarry on Millstone Hill and of the Wheaton quarry on Cobble Hill are of medium texture with feldspars to $0: 4$ inch. Its mica particles range up to 0.1 and 0.2 inch, but in the "very dark" to 0.3 inch. 


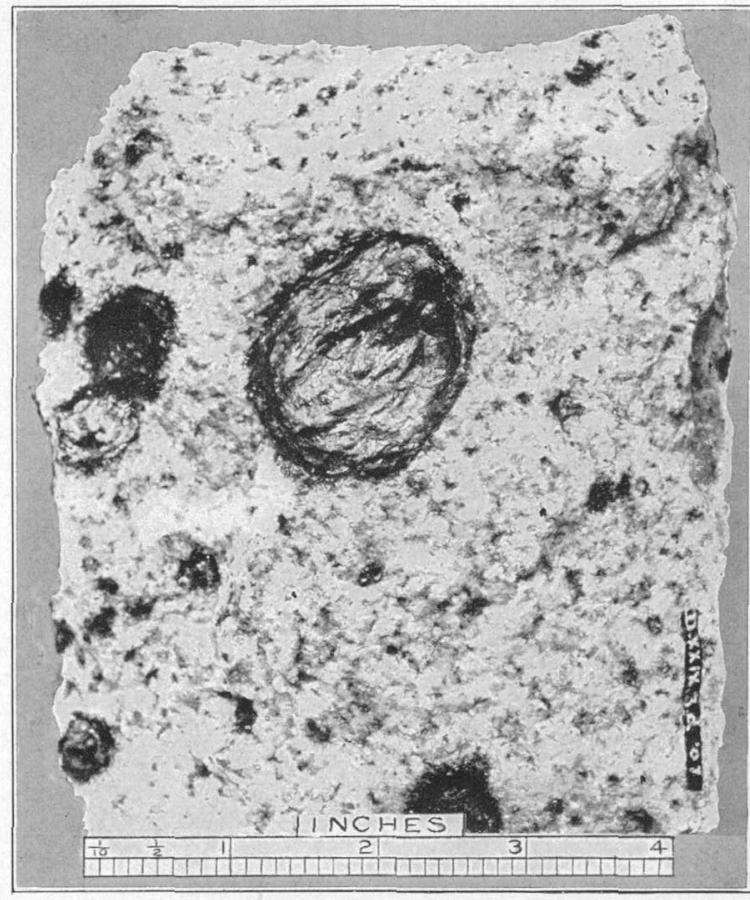

A. NODULAR GRANITE, ELLIS QUARRY, BETHEL.

The nodules are mainly muscovite, generally corrugated, and lie with their major axes in the plane of flow structure.

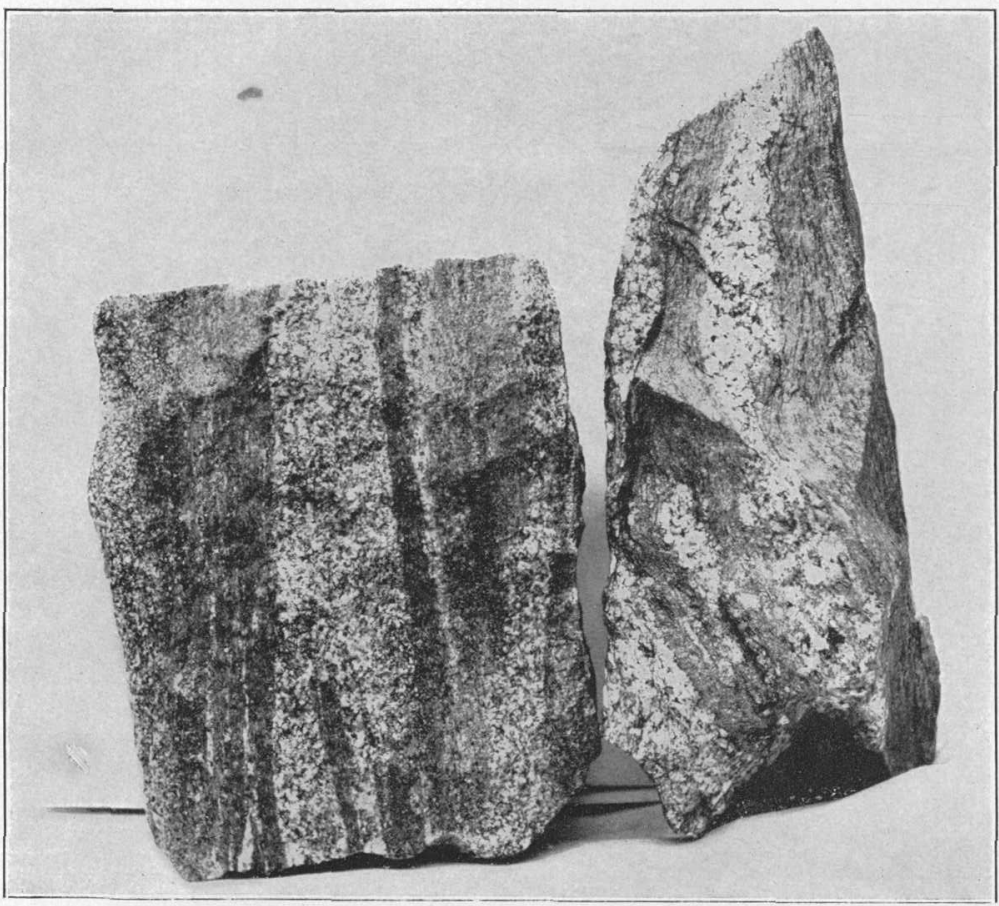

B. MICA SCHIST WITH GRANITE INJECTIONS.

Specimen at left ( 6 by 5 inches) from under side of large inclusion at Boutwell quarry, Barre, shows light granite bands alternating with dark bands of schist parallel to its foliation. Specimen at right (8.2 by 
Its constituents, in descending order of abundance, are: (a) Clear colorless or bluish to translucent, and milk-white potash feldspar (orthoclase, kaolinized, and micacized, and less of clear microcline, rarely intergrown with a little soda-lime feldspar); (b) light smoky quartz, showing optical effects of strain, rarely with rutile needles, generally with fluidal and other cavities in sheets, and with rift cracks parallel to or coinciding with them, and in some sections with another set, of fewer and shorter sheets of such cavities, at right ungles to the other and with grain cracks parallel to them (in one place the rift cracks extend into the feldspar and are there filled with fibrous muscovite) ${ }^{a}$ (c) translucent to milk-white soda-lime feldspar (oligoclase-albite to oligoclase and oligoclase-andesine), some of it with flexed twining lamellæ, more or less kaolinized and micacized, and in places with calcite; (d) biotite (black mica), some of it chloritized; (e) a little muscovite or bleached biotite. The accessory minerals are pyrite, magnetite, titanite, allanite, apatite, zircon, rutile. The secondary are calcite, abundant within the orthoclase, one or two white micas, epidote, and chlorite. Minute veinlets of quartz, of calcite, and of epidote occur exceptionally.

An estimate of the mineral percentages made by the Rosiwal method on a piece of "dark" yielded these results:

Estimated mineral percentages in "dark Barre" granite.

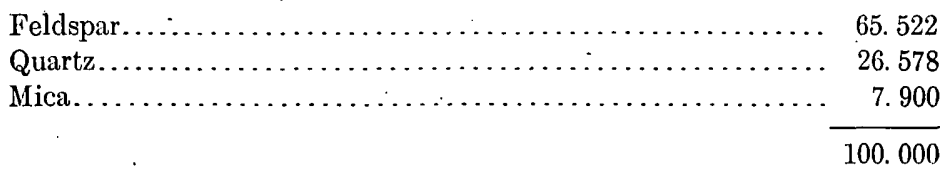

All the "Barre granites" effervesce with cold dilute muriatic acid. W. T. Schaller, chemist, of the United States Geological Survey, finds that the "light Barre" contains 0.49 per cent of $\mathrm{CaO}$ (lime), soluble in warm dilute (10 per cent) acetic acid, and the dark 0.63 per cent, indicating a content of 0.87 and 1.12 per cent of $\mathrm{CaCO}_{3}$ (lime carbonate, calcite), respectively, the presence of which mineral is also shown by the microscope.

Finlay's analysis of the darker granite from the area south of Millstone Hill is given here for reference. ${ }^{b}$

$$
\text { Analysis of "dark Barre" granite. }
$$

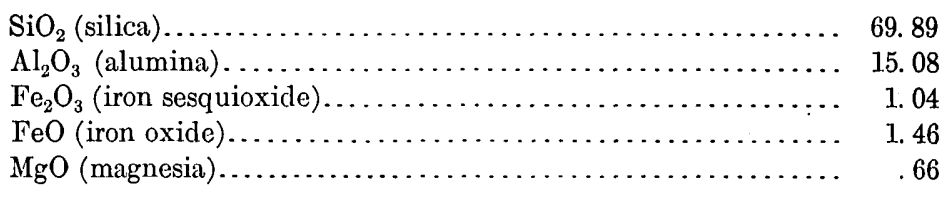

a Finlay (op. cit., p. 54) describes these rift cracks as crossing from one quartz crystal particle to another "without interruption, and as containing arborescent crystalline growths, possibly of manganese dioxide.

$b$ Op. cit., pp. 55,56 . 


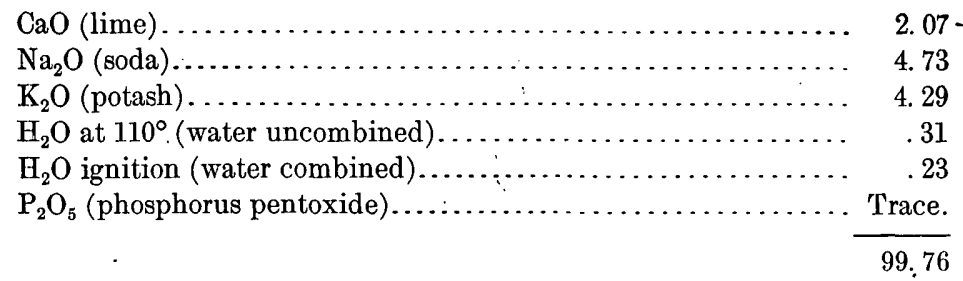

W. C. Day found the specific gravity of "dark Barre" and "medium Barre" to be 2.662 to 2.672 , and its crushing strength to range from 14,968 to 19,957 pounds per square inch. (See p. 77.) L. P. Kinnicutt in 1908 found that 100 pounds of "Barre granite" absorb 0.294 pound of water. (See p. 112.)

"Barre granite" is mostly monumental, but some is building granite. The light, medium, and dark monumental stone, although brilliant in the rough, has weak mineral contrasts, but these are stronger on the polished face of the dark. The white of the more kaolinized and micacized orthoclase feldspars and the black of the mica, and the combined bluish gray of some of the feldspar and smoke color of the quartz form three distinct shades, but owing to the fineness of the texture these merge a few feet away, and the white alone shows against a dark-gray ground. "Light Barre" granite is - never polished, but is hammered, because of the feeble contrast between the polished and cut surface, but the dark is often usedfor polished work. Its polish is fair, and the contrast between the polished and cut face is more marked along the hard way than in the rift or grain directions. In the Milne \& Wylie and Jones dark quarry stone this contrast is so marked as to imply the presence of considerable sodalime feldspar, for the contrast is almost as great as in a quartz monzonite. The polished face shows pyrite and a little magnetite.

GEOLOGY OF BARRE QUARRIES.

The granite was observed in contact with the schist at seven quarries (Pl. I, Nos. 6, 8, 9, 10,12,20). The results of a study of the contact phenomena at two of these are given on pages 21-23.

The schist inclusions have already been dwelt upon (pp. 18,19). At two quarries (Pl. I, Nos. 6, 32) these inclusions have been penetrated by minute dikes of granite and pegmatite proceeding from the granite, as has been the schist capping. At one of these quarries the granite is darkened for a space of 7 feet from the inclusion.

The sheet structure of Millstone Hill appears to form a more or less unsymmetrical flattish dome. The central part of this is exposed at the Wetmore and Morse quarry (Pl. I, No. 14), where the sheets dip from the horizontal both eastward and westward $10^{\circ}$. Westsouthwest of that point and lower down, at the Smith upper quarry (Pl. I, No. 15), they dip $10^{\circ}$ to $15^{\circ} \mathrm{SW}$., and so also in the Duffee 
quarry; still farther down, at the Smith lower quarry (Pl. I, No. 17), they dip $20^{\circ}$ to $30^{\circ} \mathrm{SW}$. On the northeast side, at the Bond \& Whitcomb quarry (Pl. I, No. 19), the sheets dip low to the northeast, and at the next quarry (Pl..I,.No. 26) $15^{\circ}$ E. ; at the Canton quarry (No. 21) $10^{\circ} \mathrm{N}$., but at the Barney quarry (No. 20) $10^{\circ} \mathrm{NE}$. and NW. At the Walker quarry (No. 23) low east and northeast. An eastnortheast to west-northwest section of the hill passing through the quarries named would thus give a general low anticlinal structure. The sheets of Cobble Hill also form a dome, for at the Wheaton quarry, north-northwest of the top, they dip $10^{\circ} \mathrm{NW}$. and NNE., but on the southwest side of the hill, at the Wildbur quarry, they dip $60^{\circ}$ S. $75^{\circ} \mathrm{W}$., and at the Bianchi quarry, farther south, $35^{\circ} \mathrm{S} .50^{\circ} \mathrm{W}$. But the sheet structure half a mile southeast of Millstone Hill (Jones and Consolidated quarries) and toward the Williamstown line is too complex to unravel. The sheets are lenticular and normal at only 21 out of the 41 quarries visited. These 21 quarries include, besides those named above, the small group of quarries in the northwest corner of the map (Pl. I), also the Milne \& Wylie, the Anderson, Acme, O'Herin, Wells-Lamson, and Pruneau quarries, also the Pirie, in Williamstown. In the remaining 20 quarries the sheets are more or less irregular or absent. In places the lenses are very short and thick, in others, as in the large Jones Bros. quarry, there are only traces of sheets. In several quarries, as the Manufacturers and Anderson quarries, the sheets "grow on"- that is, the sheet partings stop laterally, leaving the center or half of the quarry without sheets. Figure 16 shows close joints without sheets in one part of the quarry, and sheets without joints in the adjoining part. In several quarries sheet structure stops vertically at depths of 20,25 , or 35 feet from the rock surface; for example, at the Barclay, Capital, and Milne quarries. At the Smith lower quarry: there is a mass 58 feet thick without sheets; at the Bruce, one such of 48 feet; at another of 40 feet, and at the Marr \& Gordon of 80 feet. A $\hat{i}$ some quarries there is no trace of sheet structure. This incompiete development of sheet structure is the chief difficulty in quarrying at Barre. Wherever low dipping joints occur these are utilized as sheets, but where such are wanting horizontal channeling has to be resorted to, which is expensive. The sheets range from 6 inches to 30 feet in thickness. At the WellsLamson quarry the "toe-nail" structure intersects the sheets. At one quarry a sheet surface is slickensided.

There are ten sets of joints: (a), striking N. $5^{\circ}$ W. to $10^{\circ}$ E.; (b) N. $15^{\circ}$ to $20^{\circ} \mathrm{E}$.; (c) N. $30^{\circ}$ to $40^{\circ} \mathrm{E}$; ; (d) N. $45^{\circ}$ to $55^{\circ} \mathrm{E}$.; (e) N. $60^{\circ}$ to $70^{\circ} \mathrm{E}$; (f) N. $75^{\circ}$ to $90^{\circ} \mathrm{E}$.; (g) N. $60^{\circ}$ to $80^{\circ} \mathrm{W}$.; (h) N. $45^{\circ}$ to $50^{\circ} \mathrm{W}$.; (i) N. $30^{\circ}$ to $40^{\circ} \mathrm{W}$.; (j) N. $10^{\circ}$ to $25^{\circ} \mathrm{W}$. Of these (c) occurs at 21 and (f) at 18 quarries. The next most frequent are (e) and (i), each at 10 quarries, and (j) at 8 . These joints divide 
themselves into five complementary sets; that is, sets at right angles to one another and presumably due to the same strain. These sets consist of (a) and (f), (b) and (g), (c) and (h), (d) and (i), and (e) and (j). The spacing of the joints ranges from 1 to 200 feet. In 26 quarries the spacing ranges from a minimum of 1 to 8 feet to a maximum of 20 to 50 feet; in 18.quarries from a minimum of 10 to a maximum of 100 to 200 feet. Many of the joints are intermittent or discontinuous. Abnormal relations of joints and sheets are shown in figure 16 . In some quarries joints of the same strike incline in opposite directions, as shown in figure 14.

Some joints are coated with limonite and calcite; others with a greenish, usually slickensided film of muscovite, secondary quartz, and chlorite. Back of it the feldspars are microscopically brecciated and cemented with fibrous muscovite, also minutely veined with calcite and quartz. These veins run at right angles to the face. Some joint faces are very uneven and their minor protuberances slickensided. Other joint faces are coated with somewhat large muscovite scales. The slickensides of joints usually have their furrows pointing in the direction of the dip of the joint, indicating motion up or down along the dip.

Headings are numerous and usually rusty. On the northwest wall of the Marr \& Gordon quarry the central part (25 feet) of a heading striking N. $35^{\circ} \mathrm{E}$. branches off to the northwest; and at another quarry (p. 80) a heading undulates back and forth laterally.

Flow structure is rarely observable. At the Wells-Lamson quarry (Pl. I, No. 24) a 12-inch band of darker granite shows the flow to have been N. $70^{\circ} \mathrm{E}$., with an inclination of $60^{\circ} \mathrm{N} .20^{\circ} \mathrm{W}$. On Cobble Hill (Bianchi quarry) it is about north and vertical. At the Barney quarry for a space of 15 feet from the contact with schist the granite is coarse and fine in alternating bands.

Segregations are uncommon. At the Sanguinetti quarry (Pl. I, No. 18) the granite is concentrically banded in a pear-shaped mass, 1 and 2 feet in its diameters. Biotitic knots are rare and small. One 1.5 by 0.5 inch was noted. Possibly the darker, more biotitic, irregular roundish portions of the granite near the schist contacts at the Marr \& Gordon and Jones dark quarries (pp. 62, 86) are of the nature of segregations.

The rift as reported by foremen is everywhere vertical and the grain in all but two quarries is horizontal. The course of the rift about Millstone Hill and in Williamstown appears to range from N. $30^{\circ}, 35^{\circ}$, $40^{\circ}, 42^{\circ}, 45^{\circ}, 50^{\circ}, 55^{\circ}$ to $60^{\circ} \mathrm{E}$. and on Cobble Hill from N. $50^{\circ}$ to $75^{\circ} \mathrm{E}$. In the group of quarries about the Boutwell and Bruce quarries and the adjoining ones in Williamstown the rift ranges from $\mathrm{N}$. $50^{\circ}$ to $60^{\circ} \mathrm{E}$., but near the top of Millstone Hill (Duffee, Bond \& Whitcomb) from N. $30^{\circ}$ to $40^{\circ} \mathrm{E}$. At the Capital and Barre quarries 
(Pl. I, Nos. 29, 33) it is reported as varying in different blocks. At the Anderson quarry (Pl. I, No. 8) as N. $60^{\circ} \mathrm{E}$., and the grain, here better than rift, as dipping $20^{\circ} \mathrm{N}$; ; but at the Jones light quarry, only 1,500 feet away, the rift is reported as N. $35^{\circ} \mathrm{E}$. and the grain as horizontal. At the Pirie quarry the grain is reported as dipping $35^{\circ} \mathrm{N}$. $30^{\circ} \mathrm{W}$. The courses of rift and grain are thus far from uniform, and the cause of their variation is not apparent. It is to be noted, however, that the general course of the rift has a range like that of the strike of the schist foliation, which suggests the possibility of both being due to the same cause.

Pegmatite dikes are not abundant. The Pirie quarry is crossed by one 3 feet 6 inches wide, with a N. $65^{\circ} \mathrm{E}$. course, consisting almost entirely of light bluish-gray feldspars, and with a 6-inch biotitic border on either side with biotite crystals pointing toward the center. This dike has small lateral branches up to a foot long. A 1-foot pegmatite dike intervenes between schist and granite at the Anderson quarry (see fig. 5) and the schist capping is injected with minute dikes of pegmatite up to 4 feet long. (See p. 22.) At the Barney quarry a pegmatite lens occurs between granite and schist. A muscovite and feldspar (1.75 inches thick) coating on a joint plane at the Pruneau quarry (p. 78) is probably of pegmatitic origin, and likewise one of quartz and muscovite at the Manufacturers' quarry (p. 82).

Aplite occurs in irregular veinlike masses in contact with schist inclusions at two quarries. Specimen D, XXIX, 14, a, from the Jones dark quarry, is of light medium bluish greenish gray and of very fine texture with mica up to 0.05 inch, its other minerals not distinguishable. In thin section this consists of microcline, kaolinized albite to oligoclase-albite, and quartz with a little biotite, some of it chloritized, and still less muscovite or bleached biotite. It contains allanite and carbonate. Specimen 44, c, from the Bailey quarry, is of light medium purplish gray and of porphyritic texture. It consists of light purplish gray to milk-white feldspar, clear quartz, and black mica. The particles of matrix are from 0.025 to 0.1 millimeter in diameter. The porphyritic crystals (mostly oligoclase-albite, some with zonally arranged quartz, rarely microcline) measure from 0.25 to 1 by 0.5 millimeter. Pyrite is accessory.

Quartz veins, from 0.05 to 2 inches wide, are more abundant. At the Milne quarry (Pl. I, No. 34) veins of smoky quartz with diagonal fractures recur at intervals of 3 feet with a N. $60^{\circ} \mathrm{E}$. course. ${ }^{a}$ The granite for 0.2 inch next to a vein is largely feldspar. Along the edge of the vein there are bands of fibrous muscovite and, in places, streaks of granulated quartz. Sheets of fluidal cavities run discontinuously parallel to the vein and at right angles to it, and cracks here and there with granular quartz zigzag along thèse directions. Similar 
veins with pegmatite strike N. $40^{\circ} \mathrm{E}$. Both are evidently of pegmatitic origin. At the Boutwell quarry (see p. 58 and fig. 13) the granite parts along minute veins of quartz and muscovite with $\mathrm{N}$. $1.0^{\circ} \mathrm{E}$. course. Another little vein or dike with N. $80^{\circ} \mathrm{E}$. course and 0.05 inch wide consists of alternating sets of contiguous quartz and feldspar particles. The quartz particles have sheets of cavities and cracks, both parallel to the course of the vein. It has also a border, 0.25 inch wide, on either side of bleached biotite or muscovite, with chlorite, fibrous muscovite, and feldspar veined with calcite, together with magnetite particles of some size staining the rock with limonite. Quartz veins also occur at the Canton and Pruneau quarries.

Basic dikes were noted at seven quarries. At three (Jones light, Capital, and McIver \& Matheson) the exposures may all belong to one dike, which would thus be one-half mile long; and as two others (Barney and Walker quarries) are clearly the same dike, thus 800 feet long, only four dikes were actually observed. The long one is from 2 feet 6 inches to 9 feet thick with a N. $40^{\circ}$ to $45^{\circ} \mathrm{E}$. course and vertical. The other, from 1 to 2 feet thick, has a N. $35^{\circ}$ to $40^{\circ} \mathrm{E}$. course. One at the Bond \& Whitcomb quarry, up to 2 feet thick, has a $\mathrm{N} .25^{\circ} \mathrm{W}$. course and weathers spheroidally. One at the Bianchi quarry on Cobble Hill is 6 inches thick with a N. $55^{\circ} \mathrm{E}$. course. Two of these dikes were examined in thin section: The Jones light quarry dike rock is a dark greenish diabase of very fine texture (labradorite, augite, magnetite, apatite needles, secondary calcite). Its augite is altered to a chlorite-like mineral giving the greenish color. The Bond \& Whitcomb dike rock appears to be an altered camptonite of very dark gray shade and porphyritic texture with very fine matrix (plagioclase, micacized, kaolinized, and with calcite, magnetite in crystals, and skeleton crystals). The porphyritic crystals or masses appear to be hornblende more or less altered to chlorite and calcite; one is replaced by quartz.

At three quarries the granite within 1 to 2 feet of these dikes is crossed by vertical subjoints 1 to 6 inches apart parallel to the dike wall; and the granite scales off along them. These subjoints are to be regarded as the effect either of the heat of the dike or of the strain which accompanied its intrusion.

A north-south compressive strain is reported at the Bruce and Wells-Lamson quarries, and an east-west one at the Canton quarry. (See fig. 2.)

The formation of granite sand by decomposition between sheet surfaces was noted at the Innes \& Cruikshank quarry.

Rusty stain ("sap") along sheet surfaces varies greatly in amount. In many quarries it does not exceed 6 inches in thickness; in others it reaches 12,16 , and 18 , and in one place 24 inches, but that was confined to the upper sheets. Generally it is confined to the lower 
surfaces of sheets. On joint faces it is from 6 to 24 inches, and abounds on headings.

In concluding this part of the subject attention is recalled to the evidence of minor mineral and structural changes brought out in this and the previous section. The rift and grain cracks in the quartz, the straining of the quartz as shown by its optical behavior, the bending of the twinning lamellæ of the soda-lime feldspars, the formation of minute veins of secondary quartz, calcite, and epidote, the brecciation of feldspars and the formation of fibrous muscovite and of chlorite and of little veins of quartz and calcite in consequence of motion along joint planes, the formation of subjoints near basic dikes-all these facts point to crustal movements of different dates, some probably preceding the sheet and joint structure, others subsequent to it.

BOUTWELL QUARRY.

The Boutwell quarry is about south of the top of Millstone Hill, in Barre. (See Pl. I, No. 1.) Operator, Boutwell, Milne \& Varnum Company, Barre, Vt.

The granite, chiefly "dark Barre" (but also some "dark medium" and "medium"), is a biotite granite of dark, inclining to medium, bluish-gray shade and of fine, even-grained texture, with feldspars up to 0.2 inch and mica

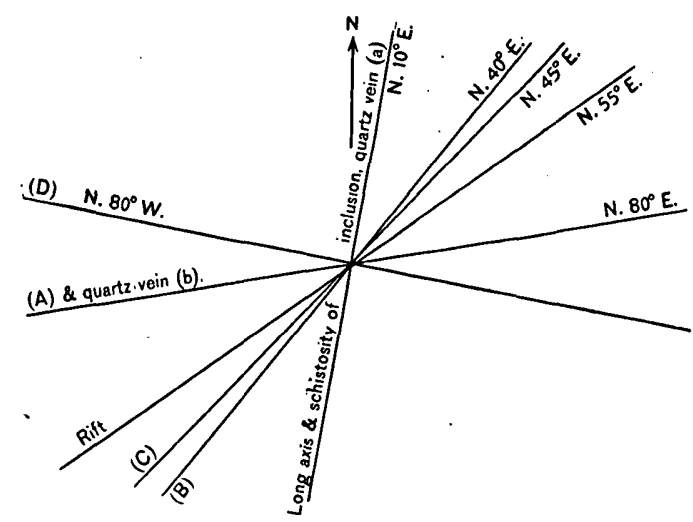

Figure 13.-Structure at Boutwell quarry, Barre.

to 0.1 inch. Its shade, texture, constituents, and qualities correspond to those of the "dark" of the Bruce quarry described on page 58.

The quarry, opened about 1886 , is somewhat T-shaped, measuring about 600 feet in a N. $80^{\circ} \mathrm{E}$. direction by 60 feet north-south at the east end and 120 feet at the west end, with a 150-foot square extension on the north side, but only 150 feet from the west end. Its depth is from 50 to 100 feet.

The sheets are irregular, 4 to 30 feet thick, striking N. $30^{\circ} \mathrm{E}$. and also east-west, and dipping $10^{\circ}, 20^{\circ}$, and $35^{\circ} \mathrm{N} .30^{\circ} \mathrm{W}$. and north. Joint, rift, and dike courses are given in figure 13 .

Joints (A) dip $55^{\circ}$ to $70^{\circ} \mathrm{S} .10^{\circ} \mathrm{W}$., are spaced 5 to 50 feet, and form the north and south walls of the main part. They are mostly limonitic or slickensided with a lustrous greenish coating, described on page 54. (B) is vertical, discontinuous, only a few feet long, forms small headings, and is coated with calcite and limonite to 
0.25 inch. One at the southeast corner dips $60^{\circ}$ N. $40^{\circ}$ W. (C) dips $10^{\circ} \mathrm{S}$., exceptional, only a few feet long, with lustrous coating, as under (A). The rift is reported as vertical and grain as horizontal. Three large schist inclusions measure respectively 55 by 10 by over 6 feet; 20 by 4 by 3 feet; and 10 by 8 feet. The first has been described on page 19. A minute vein (a) of muscovite and quartz dips $50^{\circ} \mathrm{E}$. The granite parts along it. Vein (b) is scarcely 0.05 inch wide, but has a border of dark bluish green (chloritic) or brown (limonitic), 0.25 inch wide on either side. (See further p. 56.) The "sap" is from 8 to 12 inches thick on the lower surfaces of sheets and is conspicuous in the headings.

The plant of this and the four other quarries operated by this company includes a 75-ton wooden derrick, one of 50 , three of 40 , four of 30 to 35 , one of 25 , two of 20 , two of 10 , and one of 5 tons; two hoisting engines (capacity, 15 tons on straight rope, and 25 tons with multiplied power); two Blondin carriers (capacity 15 and 5. tons) and engines; an air compressor (compound Corliss, 640 cubic feet of air per minute); 33 steam rock drills; 57 air plug drills; 18 steam pumps; and a stone crusher.

Transportation is effected by siding and connections with the Central Vermont and the Montpelier and Wells River railroads.

The product is all for monumental use, and its market is general. A specimen of the product from all the quarries of this firm is the Joseph Smith memorial at South Royalton, Vt.

BRUCE QUARRY.

The Bruce quarry adjoins the Boutwell on the southwest and lies about south of the top of Millstone Hill, in Barre. (See Pl. I, No. 2). Operators, A. E. Bruce \& Sons, Barre, Vt.

The granite (specimen D, XXIX, 12,a), "dark Barre," is a biotite granite of dark inclining to medium bluish-gray shade, and of evengrained fine texture, with feldspar up to 0.2 inch and mica to 0.1 inch. Its constituents, in descending order of abundance, are translucent bluish-gray to milk-white potash feldspar (orthoclase, kaolinized and micacized, and a little clear microcline, one such orthoclase inclosing a fresh microcline); light smoky quartz, with cavities in sheets and with cracks parallel to them (the quartz shows optical effects of strain); milk-white soda-lime feldspar (oligoclasealbite), more or less altered, rarely with bent twinning planes; biotite (black mica); and a little muscovite or bleached biotite. Accessory: Titanite, magnetite, pyrite. Secondary: Not a little calcite within the orthoclase, kaolin, one or two white micas. The stone effervesces slightly with cold dilute muriatic acid. 
Its mineral contrasts are feeble owing to fineness of texture and the lightness of quartz. There is some contrast between the polished and cut face along the hard way.

The quarry, opened in 1890 , is about 250 feet in a N. $80^{\circ} \mathrm{F}$. direction by 125 feet north-south and from 60 to 100 feet in depth.

The sheets are from 4 to 10 feet thick, and dip $5^{\circ}-10^{\circ} \mathrm{N}$. At the bottom is a mass 48 feet thick without sheets. There are three sets of joints: (a), striking N. $80^{\circ}$ E., with varying dip, forms the south wall and an 8-foot heading on the north wall, spacing 10-20 feet, but makes wedge-shaped masses owing to varying dip; (b), diagonal, "slide," strikes N. $40^{\circ}$ E., vertical, at northwest corner, with uneven slickensided face; (c), striking N. $20^{\circ} \mathrm{W}$., dipping $70^{\circ}$ N. $70^{\circ}$ E., one in center. The rift and grain are as at Boutwell quarry. A heavy north-south compressive strain is reported.

The plant comprises three derricks (50 and 15 tons), one steam and one electric engine, three large rock drills, nine air plugs drills, and two steam pumps. Compressed air is obtained from the plant of Jones Brothers.

Transportation is by siding, as shown on the map (Pl. I).

The product is used for monuments, and its market is general. Examples are the Calhoun Monument, Lexington, Ky., and 18 regimental monuments in the national cemetery at Chattanooga, Tenn.

\section{MILNE \& WYLIE QUARRY.}

The Milne \& Wylie quarry adjoins the Bruce quarry on the south, and lies about south of the top of Millstone Hill, in Barre. (See Pl. I, No. 3.) Operator, Boutwell, Milne \& Varnum Company, Barre, Vt.

The granite (specimens D, XXIX, 11, a, b, c), "dark Barre," is a biotite granite of dark bluish-gray shade, a trifle darker than that of the Bruce quarry, and of even-grained fine inclining to medium texture with feldspars up to 0.3 inch and mica to 0.12 inch. Its constituents are the same as those of the Bruce and Marr \& Gordon quarry stone described on pages 58,61 , but it contains considerable soda-lime feldspar, more or less kaolinized and micacized and with calcite. Its strong contrasts of shade between cut and polished faces also indicate the presence of an unusual amount of soda-lime feldspar, for a biotite granite. It effervesces with cold dilute muriatic acid.

An estimate of the mineral percentages by the Rosiwal method yields the following results with a mesh of 0.2 inch and a total linear length of 66.6 inches: 
Estimate of mineral percentages in Milne \& Wylie "dark Barre" granite.

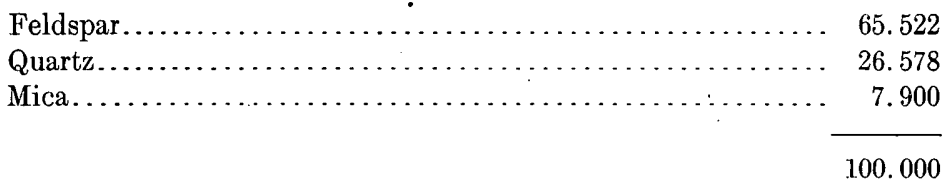

The average size of all the particles obtained from the same measurements, adding 50 per cent to the number of feldspar particles for the unseparated second feldspar, proves to be $0.069 \mathrm{inch}$, that of the feldspar 0.074 , the quartz 0.079 , and the mica 0.033 inch.

The polished face shows a little pyrite and less magnetite. The cut or hammered hard-way face is as light as the cut face of the Jones "light Barre," thus affording a very marked contrast with the polished face. The mineral contrasts in the rough are weak, but stronger on the polished face, white, black, bluish gray, and smoke color being easily distinguished in it within a distance of 2 feet. The polish is fair.

The quarry, opened about 1887, is about 400 feet east-west by 200 feet across, but with a mass 100 by 50 feet projecting into the quarry from the east wall.

The sheets, from 3 to 30 feet thick, dip $20^{\circ}$ to $30^{\circ} \mathrm{NW}$. Joints, one set only, strike nearly east-west, dip $60^{\circ}$ to $70^{\circ} \mathrm{S}$., form the north and south walls and a heading which constitutes the projecting mass on the east wall. These joints, being spaced 3 to 20 feet, cut up the sheets.

The plant is included in that of the Boutwell quarry, and the transportation and product likewise.

EMPIRE QUARRY.

The Empire quarry is southwest of the Milne \& Wylie quarry and about south-southwest of the top of Millstone Hill, in Barre, just north of the Williamstown line. (See Pl. I, No. 4.) Operator, Boutwell, Milne \& Varnum Company, Barre, Vt.

The granite is like that described from the Bruce quarry (p. 58).

The quarry, opened about 1888 , is about 375 feet in a N. $75^{\circ} \mathrm{E}$. direction by 200 feet across and from 75 to 120 feet in depth.

The sheets, from 3 to 18 feet thick, are somewhat irregular, dipping low, rarely $40^{\circ}$ to $45^{\circ} \mathrm{N}$. There are two sets of joints: (a), striking N. $65^{\circ}$ to $70^{\circ} \mathrm{E}$., dipping $65^{\circ}$ to $70^{\circ} \mathrm{S} .15^{\circ} \mathrm{E}$., is spaced 4 to 25 feet, forms a heading on the north wall, a 10-foot one on the south wall, and a 25 -foot one in the middle. This set exceptionally dips $65^{\circ}$ to $70^{\circ} \mathrm{N}$. $15^{\circ} \mathrm{W}$., forming with the rest a $\mathrm{V}$-shaped heading. in the center of the quarry, as shown in figure 14. The faces of (a) are coated with limonite and bordered with its stain. The other set (b) is exceptional, striking N. $15^{\circ}$ W., vertical. The rift and 
grain are as at adjoining quarries. There are three schist inclusions on the east wall, the largest 20 by 10 feet.

The plant, transportation, and product are covered by those items under the Boutwell quarry.

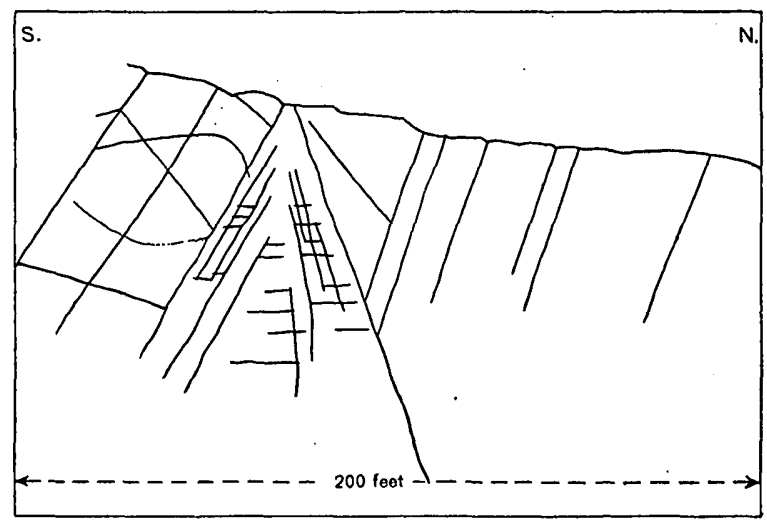

- Figure 14.--Structure on west wall of Empire quarry, Barre.

MARR \& GORDON QUARRY.

The Marr \& Gordon quarry is east-southeast of the Empire quarry and about south-southwest of the top of Millstone Hill, in Barre, just north of the Williamstown line. (See Pl. I, No. 5.) Operator, Boutwell, Milne \& Varnum Company, Barre, Vt.

The granite (specimens D, XXIX, 8, b, bb, d), "dark Barre" (derrick 9), is a biotite granite of dark bluish-gray shade and of even-grained fine texture with feldspars up to 0.2 inch and mica to 0.1 inch. Its constituents, in descending order of abundance, are: Bluish clear to translucent and milk-white potash feldspar (orthoclase, kaolinized and micacized, with a little clear microcline), some of it with minutely intergrown soda-lime feldspar; light smoky quartz with cavities in sheets and showing marked optical effects of strain; translucent to milk-white soda-lime feldspar (oligoclase to oligoclase-andesine) rarely with curved twinning lamellæ, more or less altered; biotite (black mica), rarely chloritized; very little muscovite or bleached biotite. Accessory: Pyrite, magnetite, zircon, titanite, apatite. Secondary: Calcite (in orthoclase), kaolin, one or two white micas, and chlorite.

The stone effervesces with cold dilute muriatic acid. W. T. Schaller, chemist, of the United States Geological Survey, finds that it contains 0.63 per cent of $\mathrm{CaO}$ (lime) soluble in warm dilute (10 per cent) acetic acid, which indicates a content of 1.12 per cent of $\mathrm{CaCO}$ (lime carbonate, calcite), the presence of which mineral is also shown by the microscope. 
This granite is regarded by the firm as harder and darker than the "dark" from its other quarries. It resembles that of the Milne $\&$ Wylie quarry (p. 59), but when polished shows somewhat higher mineral contrasts. It takes a fair polish. The polished face shows some pyrite and magnetite.

At the west end of the quarry, near the contact of granite and schist, is a mass (so-called knot) of still darker granite of sufficient size for commercial use. This "very dark Barre" (Specimen D, XXIX, 8, a) is a biotite granite of very dark bluish gray shade, much darker than the "dark" and as dark as "dark Quincy" a and of fine inclining to medium, even-grained texture, with feldspars up to 0.2 inch and mica to 0.3 inch. Its constituents are the same as those of "dark Barre," specimen 8 , b, etc., but the biotite is much more abundant. The second feldspar is oligoclasealbite. The stone effervesces with cold dilute muriatic acid.

In the main opening the sheets are unusually irregular. At the east end they are 18 to 20 feet thick, but in the northwest part for a depth of 80 feet there are none. In the small opening the sheets are more regular and from 4 to 14 feet thick. There. is but one set of joints, striking N. $35^{\circ} \mathrm{E}$. and vertical, forming a 20 to 25 foot heading on the northwest wall, also the northwest wall of the smaller opening, where it recurs at intervals of 3 to 10 feet. The heading in the main quarry branches off diagonally to the northwest, forming a band 20 to 30 feet wide, about halfway down the quarry. This unusual structure indicates complex strains. A.t the top of the west end the granite is in contact with a quartz-biotite schist spangled with biotite scales. The two rocks are firmly welded together in places across the foliation of the schist. Near this schist the granite is much darker from more abundant and larger biotite scales. (See p. 21.) The outline of the darker stone is quite irregular. The rift is reported as vertical, with N. $55^{\circ} \mathrm{E}$. course, and the grain as horizontal.

The plant of these openings has been included in that of the Boutwell quarry, page 58.

Transportation is by sidings, as shown on the map (Pl. I).

BAILEY QUARRY.

The Bailey quarry is southeast of the Milne \& Wylie quarry and about south of the top of Millstone Hill, in Barre. (See Pl. I, No. 6.) Operators, Woodbury \& Bailey, Graniteville, Vt.

The granite, "dark Barre," is a biotite granite of dark shade and fine even-grained texture, similar to that of the Bruce and the Milne \& Wylie quarries. 
The quarry is about 135 by 75 feet and from 10 to 35 feet in depth.

The sheets are imperfectly developed. There are two sets of joints: (a), striking N. $20^{\circ}$ W., dipping $70^{\circ} \mathrm{N} .70^{\circ}$ E., is spaced 3 to 20 feet; (b), striking N. $60^{\circ}$ E., dipping $75^{\circ}$ S. $30^{\circ}$ E., spaced 2 to 6 feet, occurs on the west side only. There the granite is in contact with schist which has a foliation strike of N. $60^{\circ}$ E., dip of $35^{\circ} \mathrm{N} .30^{\circ} \mathrm{W}$., also one of N. $20^{\circ} \mathrm{E}$., with vertical dip. At the northwest corner is a schist inclusion 26 by 5 feet, with a foliation striking N. $85^{\circ} \mathrm{W}$. and a dip of $55^{\circ} \mathrm{N}$. Dikes, large and minute, of pegmatite and aplite penetrate the schist capping and the inclusion, rendering the relations intricate. Some of the details are given on page 23 .

The plant comprises a derrick and hoisting engine, an air compressor (capacity 150 cubic feet of air per minute) driven by a 30 -horsepower electric engine, a large steam rock drill, six air plug drills, and a steam pump.

Transportation is by cart, over 4 miles to Barre.

The product is used for monuments.

BARRE GRANITE COMPANY'S QUARRY.

The Barre Granite Company's quarry consists of two openings adjoining the Bruce and the Milne \& Wylie quarries, in Barre. (See Pl. I, No. 7.) Operator, Barre Granite Company, Barre, Vt.

The granite, "dark blue," is a biotite granite of dark and dark inclining to medium bluish-gray shade and of even-grained fine or fine inclined to medium texture identical with the "dark Barre" of the Bruce and the Milne \& Wylie quarries described on pages 58, 59.

The quarries, opened about 1884, are roughly estimated as measuring about 150 by 125 feet and 60 feet square, respectively, and as about 45 feet deep.

The sheets are irregular. The jointing is like that of the adjoining quarries.

The plant comprises two derricks, a double (four-drum) hoisting engine, and a steam pump.

These quarries have not been operated since 1904, owing, it is reported, to disagreement among the partners as to necessary improvements.

\section{ANDERSON QUARRY.}

The Anderson quarry is about S. $10^{\circ} \mathrm{E}$. of the top of Millstone Hill, in Barre, 1,800 feet northeast of the Williamstown line. (See Pl. I, No. 8.) Operator, Granite City Quarry Company, Barre, Vt.

The grânite, reported by the superintendent as "dark Barre," but entered in the legend of the original quarry map of. Walker 
\& Gallison as "medium," is a biotite granite of gray shade and fine even-grained texture.

The quarry, opened about 1892, measures about 200 feet in a N. $45^{\circ} \mathrm{W}$. direction by 150 feet across and from 50 to 75 feet deep.

The granite on the southeast and northeast sides and on the southwest side for 50 feet west of the south corner is capped by schist and slate up to 15 feet thick, with a cleavage and schistosity striking N. $30^{\circ}$ E. and dipping $55^{\circ} \mathrm{N} .40^{\circ} \mathrm{W}$. The relations of granite and slate are shown in figures 5 and 6 , and the contact phenomena have been given on page 21 . The sheets, from 1 to 15 feet thick, dip $20^{\circ} \mathrm{NW}$. There are three sets of joints: (a), striking N. $50^{\circ} \mathrm{W}$., dipping $75^{\circ} \mathrm{N} .50^{\circ}$ E., occurs on the southwest side only; (b), striking N. $5^{\circ}$ E. and dipping $70^{\circ}$ E., is spaced 6 to 15 feet; (c), striking N. $60^{\circ}$ E. and dipping $75^{\circ}$, is spaced 3,15 , and over 25 feet. The rift is reported as vertical, with N. $60^{\circ}$ E. course; the grain as dipping with the sheets $20^{\circ} \mathrm{NW}$., and as easier than the rift. A 1-foot pegmatite dike borders one of the schist masses, as shown in figure 5. At the east side there are two schist inclusions, measuring 10 by 2 to 3 feet and 6 by 2 feet, respectively, besides minor fragments.

The plant consists of a derrick, a Blondin carrier, two engines, an air compressor (capacity about 200 cubic feet of air per minute) driven by the Blondin engine, two large rock drills, four air plug drills, and a steam pump.

Transportation is by cart, over 4 miles to Barre.

The product is used entirely for monuments.

STEPHEN \& GERRARD QUARRY.

The Stephen \& Gerrard quarry is 600 feet north of the Anderson quarry and from south to south-southeast of the top of Millstone Hill, in Barre. (See Pl. I, No. 9.) Operators, Stephen \& Gerrard, Barre, Vt.

The granite, reported by the firm as "medium Barre," but entered on Walker \& Gallison's original map as "light," is a biotite granite of gray shade and of even-grained fine texture. For descriptions of "medium Barre" and "light Barre," see pages 65, 71. The quarry measures about 175 feet in a N. $30^{\circ}$ E. direction by 150 feet across and from 20 to 50 feet in depth.

The sheets are undeveloped in the west half of the quarry, but the closely spaced joints there serve the quarrymen instead. Rift and joint courses are shown in figure 15 and the complex relations on the north wall in figure 16. There are four sets of joints: (A) dips $35^{\circ} \mathrm{S}$. $40^{\circ} \mathrm{E}$., and is spaced 3 to $17 \mathrm{feet}$; (B), vertical, is spaced 30,40 to 90 feet and forms the south wall; (C), diagonal, dips $35^{\circ} \mathrm{E}$., one only in east half; (D), vertical, forms heading on south wall. The granite is 
in contact on the west side and southeast corner with schist which has a foliation striking N. $30^{\circ} \mathrm{E}$. and dipping $50^{\circ} \mathrm{N} .60^{\circ} \mathrm{W}$. Rusty stain is from 1 to 6 inches thick on sheet and joint faces.

The plant consists of two derricks (one of 40 tons), two hoisting engines, a small air compressor, two large rock drills, five air plug drills, and a steam pump.

Transportation is bycart, $4 \frac{1}{2}$ miles to cutting sheds.

The product is used entirely for monuments.

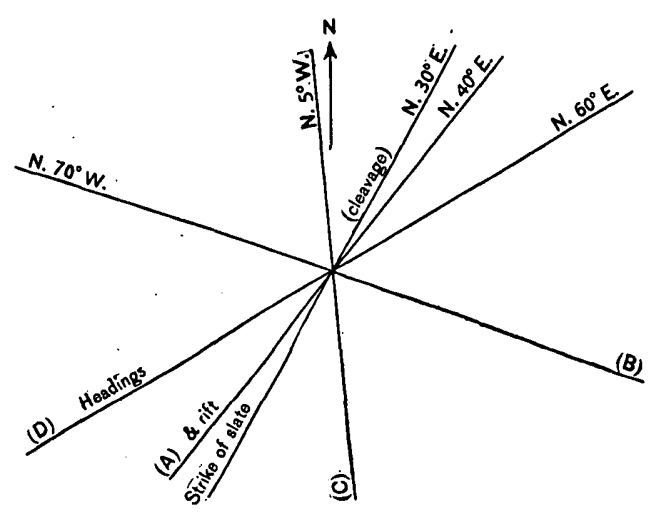

FigURE 15.-General structure at Stephen \& Gerrard quarry, Barre, vt.

JONES LIGH'T QUARRY.

The Jones Light quarry is about northeast of the last and southsoutheast of the top of Millstone Hill, in Barre. (See Pl. I, Nos. 10 and 11.) Operator, Jones Brothers Company, Barre, Vt.

The granite (specimen D, XXIX, 27, b), "light Barre," is a biotite granite of light, very slightly bluish gray shade. Its position among the light granites is between that of North Jay, Me., which is very light gray, and that of Hallowell, Me., which is light, inclining to medium. ${ }^{a}$ Its texture is even grained, fine inclining to medium, with feldspar up to 0.2 inch, rarely 0.3 inch, and mica to 0.1 inch. Its constituents, in descending order of abundance, are: Clear, colorless to bluish translucent and milk-white potash feldspar (orthoclase, kaolinized and micacized, with fresh microcline); very light smoky quartz with sheets of cavities with brightly polarizing rift or grain cracks parallel to or coinciding with them; translucent to milkwhite soda-lime feldspar (oligoclase-albite, more or less altered), rarely with bent twinning planes; biotite (black mica), some of it chloritized; very little muscovite or bleached biotite. Accessory: Magnetite (very little) and zircon. Secondary: Calcite, usually in the orthoclase, kaolin, one or two white micas, and chlorite.

The stone effervesces with cold dilute muriatic acid. W.T.Schaller, chemist, of the United States Geological Survey, finds that it contains 0.49 per cent of $\mathrm{CaO}$ (lime) soluble in warm dilute (10 per cent)

a See Bull. U. S. Geol. Surv. No. 313, 1907, pp. 80, 117.

4782-Bull. $404-09-5$ 
acetic acid, which indicates a content of 0.87 per cent of $\mathrm{CaCO}_{3}$ (lime carbonate, calcite), the presence of which is also shown in thin section.

The mineral contrasts are feeble and so are those between cut and polished faces. The stone is used for rough, hammered, and carved monumental work.

The quarry consists of two openings. The main and older one measures over 550 feet in a N. $35^{\circ}$ E. direction by 60 to 200 feet across, and 40 to 90 feet in depth. The new one, which lies 300 feet. N. $30^{\circ}$ E. from the north end of the other, is about 200 feet square and 50 feet deep.

Joint, rift, and dike courses are shown in figure 17 . Sheet structure is hardly developed or very irregular. Traces of sheets dip $10^{\circ} \mathrm{W}$. On account of this much horizontal channeling has to be done. There are six sets of joints: (A), diagonal and vertical; (B), also vertical, spaced 20 to 30,50 feet and over; (C) dips $45^{\circ} \mathrm{S} .45^{\circ}$ E., discontinuous, occurs here and there in north part of quarry; (D) dips $45^{\circ} \mathrm{W}$.,

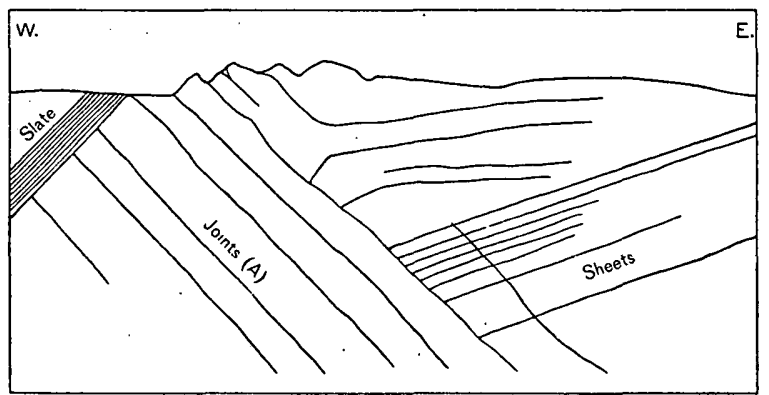

FIǴURE 16.-Structure on morth wall of Stephen \& Gerrard quarry, Barre, vt.

undulating, occurs with (C); (E), in new opening, dips $45^{\circ}$ N. $65^{\circ}$ E., spaced 3 to 50 feet, forms a heading at northwest corner; (F), in new opening, dips steeply N. $58^{\circ}$ E., several at north end. There is a schist capping on the west wall of the main opening 10 to 20 feet and more thick, and on part of east wall, and also forming the east wall of new opening. Its foliation strikes $\mathrm{N} .35^{\circ} \mathrm{E}$. and dips steeply west to $90^{\circ}$. The schist is said to continue indefinitely on the east and also to be at least 150 feet wide on the west. Rift is vertical and good, the grain horizontal. A vertical diabase dike, 8 feet thick, crosses the north half of the main quarry diagonally, and also the schist capping. (See, further, p. 56.) Thirty feet below the granite surface is a schist inclusion 30 feet long and up to 3 feet thick, tapering.

The plant, for both openings, includes two 65-ton derricks, two 40-ton ones, and two smaller; a 125-horsepower hoisting engine, one of 50, and two of 40 ; an air compressor (capacity 750 cubic feet of air per minute; 11 lairge rock drills, 20 air plug drills, and two steam pumps. 
The cutting plant, which is in Barre, includes an outside 100-ton derrick, two pneumatic 3-ton hoists, three overhead 20-ton cranes, an air compressor (capacity 1,200 cubic feet of air per minute), six air plug drills, 180 air hand tools, seven surfacers, seven polishers, two cutting lathes for stones 25 by 3 feet, a polishing lathe for stones of the same size, two gangs of stone saws for stones 12 by 7 feet, two MacDonald rotary surfacers, an automatic polishing carriage with bed 18 by 4 feet, a Cavecchi polishing machine, and three granite-boring machines. Power is supplied by a 150-horsepower Corliss engine and also by Stephen Brook.

Transportation is effected by sidings from the quarry and the cutting plant, which are several miles apart.

The product is used for rough and hammered face and carved monuments. The following specimen monuments combine the product of this quarry with that of the firm's dark quarry described on page 85: Ohio and Iowa state soldiers' monuments, Chattanooga, Tenn.; Governor Curtin monument, Bellefonte, Pa.; state soldiers' monument, York, Pa.; Hearn monument, with monolithic spire 53 by 4 by 4 feet, Woodlawn, N. Y.; Rouse mausoleum, Winchester, Va.; Krueger mausoleum, Newark, N. J.; Gary mausoleum, with roof stones of the "light," 35 by 9 feet 6 inches by 1 foot 6 inches each, Wheaton, $\mathrm{Ill}$.

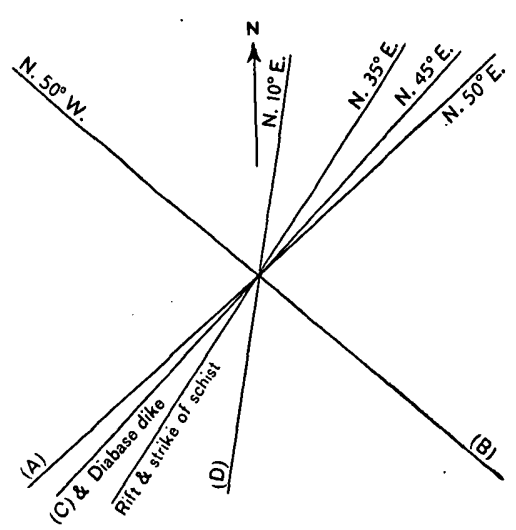

Figure 17.-Structure at Jones Light, main quarry, Barre.

BARCLAY QUARRY.

The Barclay quarry is the S. $35^{\circ} \mathrm{W}$. continuation of the large Jones Light quarry, as shown on Plate I, No. 12. Operators, Barclay Brothers, Barre, Vt.

The granite, "light Barre," is a biotite granite of light, slightly bluish gray shade and even-grained fine inclining to medium texture, identical in every respect with that of the Jones Light quarry described on page 65 , but the lower part of the quarry is said to have yielded "medium Barre" granite.

The quarry, 220 by 100 feet, is about 75 feet deep. The firm owns also another quarry in line with this, the "Sunnyside," which, however, was idle in 1907.

The sheets from 6 inches to 12 feet and over in thickness dip $20^{\circ}$ NW., but sheet structure terminates at a depth of 35 feet. Joints and rift are the same as in the Jones Light quarry. The granite is 
capped by schist on the northwest side. The schist is spangled with minute crystals of biotite and with a few garnets.

The plant at the quarry comprises a 30-ton and a 40-ton derrick, two hoisting engines, an air compressor, two large rock drills, three smaller ones, four air plug drills, and a steam pump. At the cutting shed in Barre it comprises a hand derrick, two overhead 40-ton cranes, three air compressors (capacity, two of 250 and one of 75 cubic feet of air per minute), two air plug drills, two surfacers, 45 air hand tools, two cutting lathes for stones 20 feet by 3 feet 6 inches and 9 feet by 1 foot 10 inches, two polishing lathes for stones 20 by 5 feet and 10 by 3 feet, a stone saw (for use with chilled shot) for: stones 15 by 8 by 7 feet, four polishers, a pneumatic Cavecchi polisher, and ten electric motors. Electric power is brought from Bolton and Middlesex Falls.

Transportation is by cart, 4 miles to Barre.

The product is used for monuments and memorial chapels. Specimens are the Robert Burns statue and pedestal, Barre, shown in Plate III, $A$; First North Dakota soldiers' memorial, St. Paul, Minn.; Indian massacre memorial, Serena, Ill.; Wade memorial chapel, Cleveland, Ohio; Hancock (canopy) memorial, San Francisco, Cal.; Doctor Kimball memorial, Concord, N. H.; General Thomas (shaft) memorial, Springfield, Ohio; Senator Dillon shaft, Davenport, Iowa.

ACME GRANITE QUARRY.

The Acme granite quarry is about 600 feet west-southwest of the Jones Light quarry, in Barre. (See Pl. I, No. 13.) Operator, C. N. Scott, East Barre, Vt.

The granite, "dark medium Barre," is a biotite granite of medium bluish-gray shade and even-grained fine texture.

The quarry consists of two openings, the smaller of which, made in 1905 , is alone now in use. It measures about 20 feet N. $60^{\circ} \mathrm{E}$. by 30 feet across and 10 to 25 feet in depth.

The sheets, 1 to 20 feet thick, dip $20^{\circ} \mathrm{NNE}$. There are two sets of joints: (a), striking N. $50^{\circ}$ to $55^{\circ}$ E., dipping $65^{\circ}$ to $90^{\circ}$, forms the south wall and a heading on the north wall; (b) strikes N. $35^{\circ} \mathrm{W}$., is vertical, one only. The rift is reported as vertical and parallel to (a).

The plant comprises one horse derrick, two steam derricks, and a 45-horsepower hoisting engine, a large rock drill, and a steam pump.

Transportation is by siding, as shown on Plate I.

The product is used for monuments.

\section{WETMORE \& MORSE QUARRY.}

The Wetmore \& Morse quarry, 1,007 feet above the city, lies in a saddle about south-southeast of the top of Millstone Hill and about 200 feet below it. (See Pl. I, No. 14.) Operator, Wetmore \& Morse Granite Company, Montpelier, Vt. 


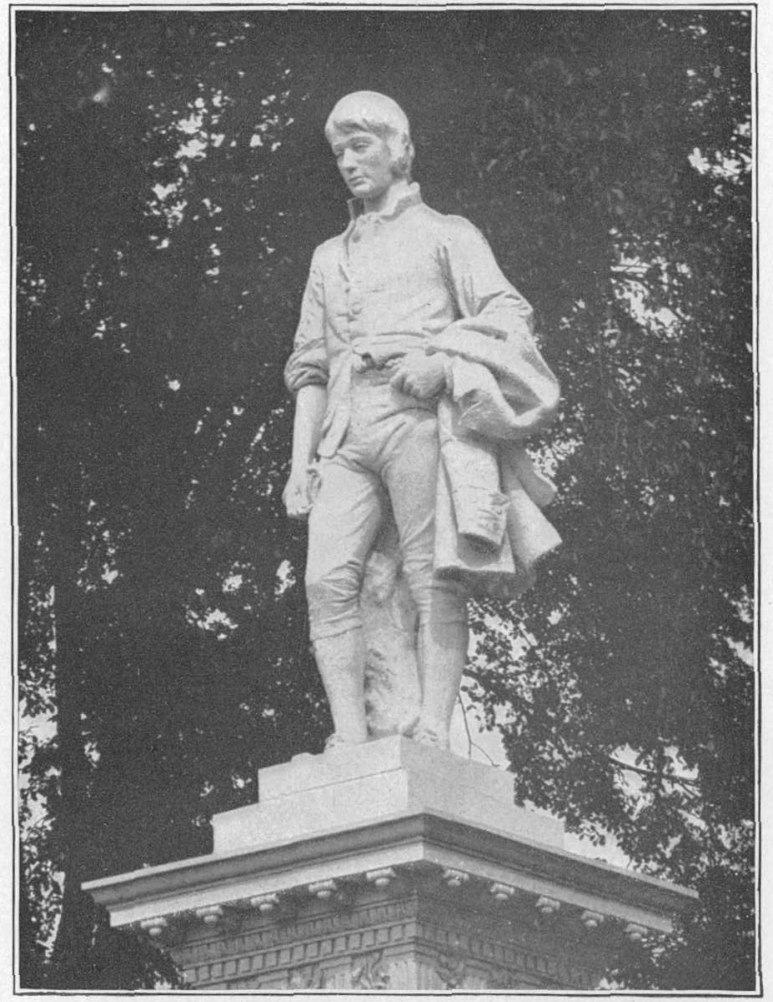

A. STATUE OF ROBERT BURNS AT BARRE, SHOWING ADAPTABILITY OF "BARRE GRANITE" TO SCULPTURE.

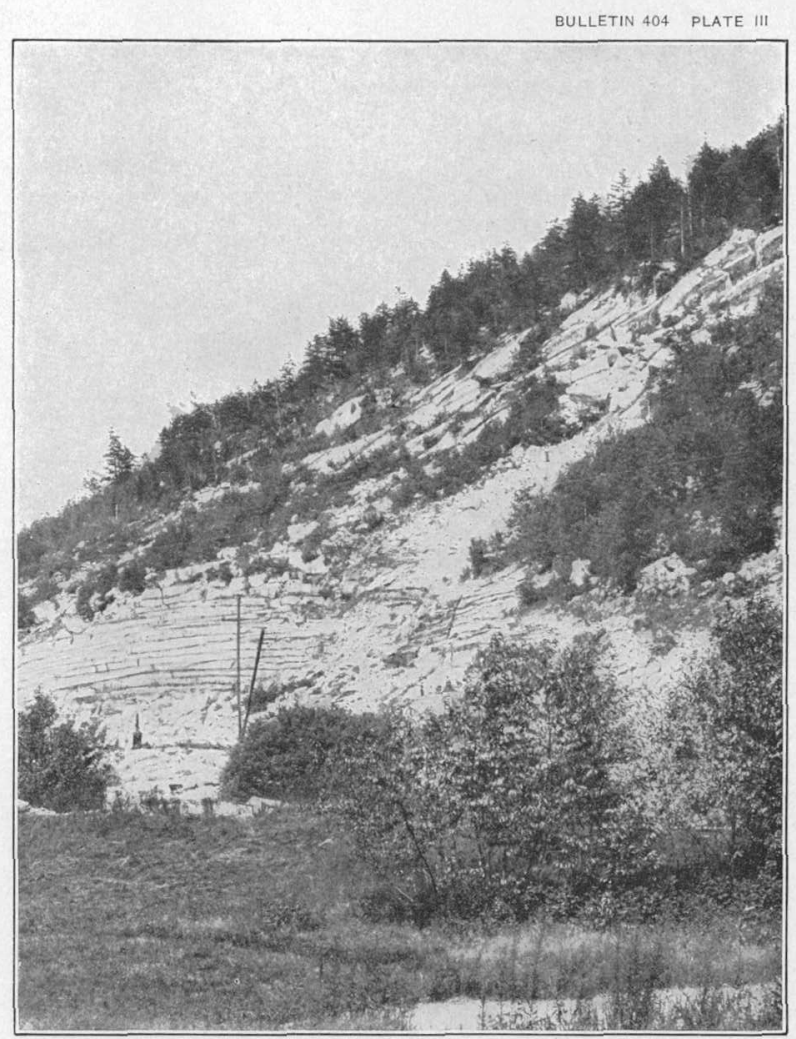

B. SHEET STRUCTURE AT SOUTHWEST FOOT OF BLACK MOUNTAIN IN DUMMERSTON ("BLACK MOUNTAIN QUARRY").

The sheets in the working face are thin and nearly horizontal; those higher
up the dome are thicker and dip $30^{\circ}-40^{\circ} \mathrm{W}$. 
The granite (specimen D, XXIX, 19, b), "light Barre," is a biotite granite of light, medium, slightly bluish gray shade (darker than that of the Jones Light quarry and that of Hallowell, Me., but lighter than that of Concord, N. H., "Concord granite") and of even-grained fine inclining to medium texture, with feldspar up to 0.3 inch and mica not over 0.1 inch. Its constituents, qualities, etc., are identical with those of specimen 18, a, from the Smith Upper quarry described on page 70. The quarry yields also some "medium."

The stone effervesces with cold dilute muriatic acid. W. T. Schaller, chemist, of the United States Geological Survey, finds that it contains 0.49 per cent of $\mathrm{CaO}$ (lime) soluble in warm dilute (10 per cent) acetic acid, indicating a content of 0.87 per cent of $\mathrm{CaCO}_{3}$ (lime carbonate, calcite), the presence of which mineral is also shown in thin section.

The quarry, opened about 1875 , measures about 610 feet in a N. $60^{\circ}$ E. direction by 100 to 200 feet across and from 50 to 75 feet in depth.

The sheets are from 1 to 28 feet thick. The quarry cuts the axis of the hill so as to show the arching of the sheets on the north-northwest wall. They are horizontal in the center at the top and dip $10^{\circ} \mathrm{E}$. and W., but in the center at the bottom they dip $15^{\circ} \mathrm{SSW}$., showing the dome structure of the hill. There are four sets of joints: (a) Striking N. $60^{\circ}$ E., vertical and steep S. $22^{\circ}$ E., forms part of the south-southeast wall; (b) striking N. $82^{\circ}$ E., dipping almost $90^{\circ}$, forms part of the north-northwest wall; (c) striking N. $35^{\circ} \mathrm{W}$., vertical, occurring only in the north half of the quarry, are coated with chlorite and sericite (one of these dies out on the south in such a slickensided plane dipping low south); (d) striking N. $30^{\circ}$ E. and dipping $45^{\circ} \mathrm{N} .60^{\circ} \mathrm{W}$, greenish, slickensided. The quarry is somewhat difficult to work on account of scarcity of joints. The rift is reported as vertical with northeasterly course and the grain as horizontal. Rusty stain is up to 2 feet thick on upper sheets, but disappears entirely below.

The plant consists of two 60-ton, one 50-ton, and one 30-ton derricks, three electric hoisting engines of 55,30 , and 20 horsepower, an air compressor (capacity 840 cubic feet of air per minute) driven by a 150-horsepower electric motor, 10 large air rock drills, 15 air plug drills, and three steam pumps.

Transportation is by a siding, as shown on the map (Pl. I).

The product is used for monuments, 75 per cent of it reaching the market through local cutting sheds. Specimen: The J. D. Rockefeller monument at Cleveland, Ohio.

SMITH UPPER QUARRY

The Smith Upper quarry, southwest of and below the last, is S. $32^{\circ}$ W. of the top of Millstone Hill, in Barre. (See Pl. I, No. 15.) Operators, E. L. Smith \& Co., Barre, Vt. 
The granite (specimen D, XXIX, 18, a), "light Barre,". is a biotite granite of light, medium, slightly bluish gray shade (darker than the "light" of the Jones quarry and that of Hallowell, Me., which are light inclining to medium gray, but lighter than that of Concord, $\mathrm{N}$. H., which is medium gray) and of even-grained fine inclining to medium texture with feldspar up to 0.3 inch and mica not over 0.1 inch. Its constituents, in descending order of abundance, are: Clear, colorless to bluish translucent and milk-white potash feldspar (orthoclase, kaolinized and micacized, with a little fresh microcline); light smoky quartz with cavities in sheets with cracks parallel to or coinciding with them; translucent to milk-white soda-lime feldspar (oligoclase-albite more or less altered) rarely with flexed twinning planes; biotite (black mica), some of it chloritized and with epidote; a little muscovite or bleached biotite. Accessory: Pyrite, magnetite, titanite, apatite, zircon. Secondary: Calcite, generally in the ortho-

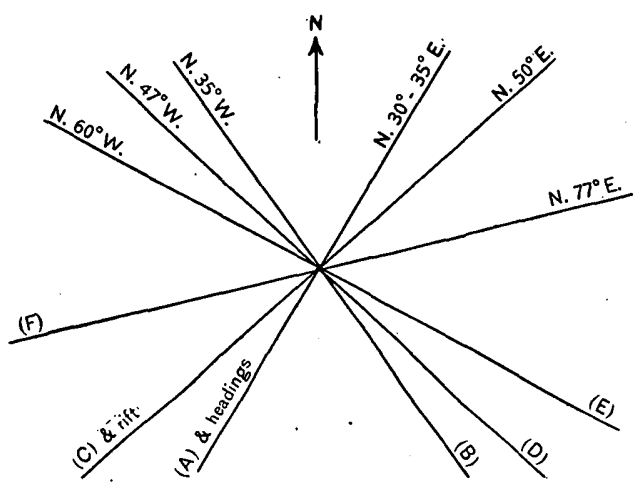

FIGURE 18.-Structure at Smith Upper, Smith Iower, and Duffee quarries. clase, kaolin, one or two white micas, chlorite, and epidote. It effervesces slightly with . cold dilute muriatic acid.

The mineral contrasts are feeble.

The quarry is very irregular in outline, measuring about 400 feet in a $\mathrm{N} .30^{\circ} \mathrm{E}$. direction by 200 feet across and 30 to 60 feet in depth.

The sheets, from 1 to 10 , exceptionally 20 feet thick, are horizontal at the north end, but elsewhere bend over to the southwest $10^{\circ}$ to $15^{\circ}$. Joint and rift courses of this and Duffee and Smith Lower quarries are combined in figure 18. There are two sets of joints: (A), vertical, forming headings on the northwest and southeast walls; (B), dipping $75^{\circ} \mathrm{SW}$., is spaced 10 to 30 feet and over. The rift is reported as vertical and grain as horizontal. Rusty stain is from 1 to 18 inches thick, but there is little of it on the upper surfaces of sheets.

The plant for this and the two other Smith quarries comprises six 50-ton, four 20 -ton, and four smaller derricks, an air compressor (capacity 1,800 cubic feet of air per minute), 10 hoisting engines, a Blondin carrier and engine, 25 large air rock drills, 40 air plug drills, and eight steam pumps. The firm's cutting plant at Barre includes two derricks, an overhead 20-ton crane, a hand crane, an air compressor (capacity 350 cubic feet of air per minute), four air plug drills, 50 air hand tools, three surfacers, three polishers, and two 
electric motors (50 and 10 horsepower) for derricks, cranes, compressor, and polisher. Electricity is supplied by the Consolidated Lighting Company from falls on Winooski River, about 13 and 20 miles from Barre.

Transportation is by sidings, as shown on the map (Pl. I).

The product is monumental stone. Specimens of monuments from all the quarries of E. L. Smith \& Co. are: Pedestal of equestrian statue of St. Louis, erected by W. R. Hodges in 1906, and Lemp mausoleum, St. Louis, Mo.; Cluett obelisk, with 44-foot shaft and pedestal, Troy, N. Y.; Smith obelisk, Old cemetery, Barre; the stone for Fleischmann mausoleum, Cincinnati.

DUFFEE QUARRY.

The Duffee quarry is west-northwest of and lower than the Smith Upper quarry and southwest of the top of Millstone Hill, in Barre. (See Pl. I, No. 16.) Operators, E. L. Smith \& Co., Barre, Vt.

The granite (specimen D, XXIX, 17, a), "medium Barre," is a biotite granite of medium bluish-gray shade (a trifle darker than "Concord granite") and of even-grained fine texture with feldspars up to 0.2 inch and mica rarely to 0.1 inch. Its constituents, in descending order of abundance, are: Bluish translucent to milkwhite potash feldspar (orthoclase, kaolinized and micacized, with a little fresh microcline); light smoky quartz with cavities in sheets and with cracks parallel to them, also showing optical effects of strain; translucent to milk-white soda-lime feldspar (oligoclasealbite, more or less altered), some of it with curving twinning planes; biotite (black mica), some of it chloritized; a little muscovite or bleached biotite. There are microscopic veins of epidote, of quartz, and of calcite. Accessory: Allanite, zircon, probably also magneite and pyrite, although not in section. Secondary: Calcite, usually in orthoclase, kaolin, one or two white micas, epidote, quartz, chlorite. The stone effervesces slightly with cold dilute muriatic acid. The quarry produces some "dark" also.

The mineral contrasts are weaker than in the "dark" or in the "light" of the Jones or Smith Upper quarries, because of greater fineness of mica and more bluish cast of feldspar.

The quarry is estimated as about 400 feet east to west on one side and 300 on the other by 200 feet across and about 40 feet in depth.

The sheets, 2 to 12 feet thick, are somewhat regular; dipping $15^{\circ}$ SW. with the rock surface. There are four sets of joints (see fig. 18): (A), dipping $75^{\circ} \mathrm{S} .60^{\circ} \mathrm{E}$., forms a 15 -foot heading through the center of the quarry, and is spaced 10 to 100 feet; (B) dips $60^{\circ} \mathrm{N} .55^{\circ} \mathrm{E}$., one only in southwest part; (C) dips $60^{\circ} \mathrm{S} .40^{\circ} \mathrm{E}$;, one on south wall; (D) dips S. $43^{\circ} \mathrm{W}$., one on southeast wall. The rift is reported as vertical and the grain as horizontal. 
The plant and product have been given in connection with the Smith Upper quarry, page 70. Transportation is by siding, as shown on Plate I.

SMITH LOWER QUARRY.

The Smith Lower quarry is west-northwest of the Duffee quarry near the foot of Millstone Hill and S. $60^{\circ} \mathrm{W}$. from its top, in Barre. (See Pl. I, No. 17.) Operator, E. L. Smith \& Co., Barre, Vt.

The granite, "medium Barre," is identical with that of the adjoining Duffee quarry described above. The quarry also yields some "dark."

The quarry is estimated as about 250 feet east to west by 200 feet across, and from 50 to 100 feet in depth.

The sheets, from 1 to 15 feet thick, dip $20^{\circ}$ to $30^{\circ} \mathrm{SW}$., but in the lower part is a mass 58 feet thick without sheets. Joint and rift courses are shown in figure 18 : (A), dipping $80^{\circ} \mathrm{S} .60^{\circ} \mathrm{E}$., forms the east wall and a heading on the southwest wall, and recurs 20 feet south of the north wall; (B) dips $50^{\circ} \mathrm{NNW}$. (two of this set, 8 feet apart, are in the southeast corner); (C) dips $40^{\circ}$ N. $55^{\circ}$ E., one only, discontinuous, on northeast wall. Rift and grain as at adjacent quarries.

The plant and product are given in connection with Smith Upper quarry. Transportation is by siding, as shown in Plate I.

SANGUINETTI QUARRY.

The Sanguinetti quarry is about three-fifths mile north of the top of Millstone Hill, in Barre. (See Pl. I, No. 18.) Operator, Joseph Sanguinetti, Barre, Vt.

The exact shade of biotite granite obtained here was not determined. The quarry was temporarily idle in 1907.

The quarry is about 100 feet by 50, and from 10 to 20 feet deep. The sheets, 8 to 10 feet thick, are imperfectly developed. Joints (a) strike N. $35^{\circ} \mathrm{E}$., dip S. $55^{\circ} \mathrm{E}$., and are spaced 10 to 20 feet; joints (b) strike N. $75^{\circ} \mathrm{W}$., dip $65^{\circ}$ to $80^{\circ} \mathrm{S} .15^{\circ} \mathrm{W}$., and are spaced 10 to 50 feet. There are some biotitic flowage streaks, also a pear-shaped concentrically banded mass 1 to 2 feet across. A schist outcrop between the quarry and railroad has a foliation strike north and a dip $55^{\circ} \mathrm{W}$.

The plant consists of a derrick and small hoisting engine.

BOND \& WHITCOMB QUARRY.

The Bond \& Whitcomb quarry is N. $40^{\circ}$ E. from the top of Millstone Hill and 200 feet below it, or 1,000 feet above the city, in Barre. (See Pl. I, No. 19.) Operators, Bond \& Whitcomb, Barre, Vt.

The granite (specimen D, XXIX, 26, a), "coarse light Barre," is a biotite granite of light-gray shade, owing to more biotite a trifle darker than the "light" of Jones quarry, and of even-grained medium texture 
with feldspars up to $0.3 \mathrm{inch}$, exceptionally $0.4 \mathrm{inch}$, and mica to 0.2 inch. Its constituents, in descending order of abundance, are: Clear colorless to milk-white potash feldspar (orthoclase, kaolinized and micacized, with a little fresh microcline, rarely inclosed by the former); light smoky quartz with cavities in sheets with rift cracks parallel to them, also showing optical effects of strain; whitish soda-lime feldspar (oligoclase to oligoclase-andesine) more or less altered; biotite (black mica), some of it chloritized; a little muscovite or bleached biotite. Accessory: Titanite. Secondary: Calcite, generally within the orthoclase, kaolin, one or two micas, chlorite. The stone effervesces with cold dilute muriatic acid.

This is a light constructional granite.

In a new opening a little north of the main one the stone (specimen D, XXIX, 26, b) "medium Barre," is a biotite granite of medium gray shade and fine texture with feldspars up to 0.2 inch, rarely 0.3 inch, and mica not over 0.1 inch. Its constituents are the same as in the coarser granite, excepting that the soda-lime feldspar is oligoclase and some of the orthoclase is fresh. The stone effervesces slightly with cold dilute muriatic acid.

This is a monumental granite.

The main quarry, opened in 1902 , measures about 200 feet in a $\mathrm{N}$. $35^{\circ}$ E. direction by 150 feet N. $25^{\circ} \mathrm{W}$., and is from 1.0 to 30 feet in depth.

The sheets are regular, 6 inches to 7 feet thick, and dip gently northeast. There are two sets of joints: (a) Striking N. $25^{\circ}$ W., vertical, forms the northeast wall and a heading 75 feet from the southwest wall; (b) striking N. $35^{\circ}$ E., vertical and steep N. $55^{\circ}$ W., one only, forming the north wall. Some of the joint faces are coated with muscovite scales. The rift is reported as vertical with $\mathrm{N}$. $35^{\circ}$ to $40^{\circ}$ E. course and the grain as horizontal. For spaces 1 to 2 inches wide the granite has very little biotite, and the average size of feldspars is there greater. A basic dike, described on page 56 , runs parallel to the north wall and a little back of it. It is 2 feet thick but tapers out at heading (a). Rusty stain does not exceed $1 \frac{1}{2}$ inches on sheet surfaces.

The plant consists of two derricks, two hoisting engines, a small air compressor, three large rock drills, five air plug drills, and a siphon pipe.

Transportation is by siding, as shown on Plate I.

The product is used as dimension stone for buildings; that from the small opening is used for monuments. 
BARNEY QUARRY.

The Barney quarry (formerly known as the Eclipse) is 360 feet north-northeast from the last and about N. $35^{\circ} \mathrm{E}$. from the top of Millstone Hill, in Barre. (See Pl. I, No. 20.) Operator, Augusta Barney, Websterville, Vt.

The granite, "medium and light Barre," is a biotite granite of medium and light bluish gray shade and fine texture, like those already described.

The quarry is estimated as measuring about 300 feet in a northeast direction by 200 feet across and from 45 to 60 feet in depth.

The sheets, 1 foot to 3 feet 8 inches thick, are normal and dip about $10^{\circ} \mathrm{NW}$. on the northwest side, but $10^{\circ} \mathrm{SE}$. on the southeast side, with a S. $10^{\circ} \mathrm{W}$. pitch of $10^{\circ}$, and they are slickensided in a S. $50^{\circ}$ W. direction. Joints, rift, and dike courses are shown in figure 19. Joints (A), vertical, form a 3 -foot heading on the southwest wall;

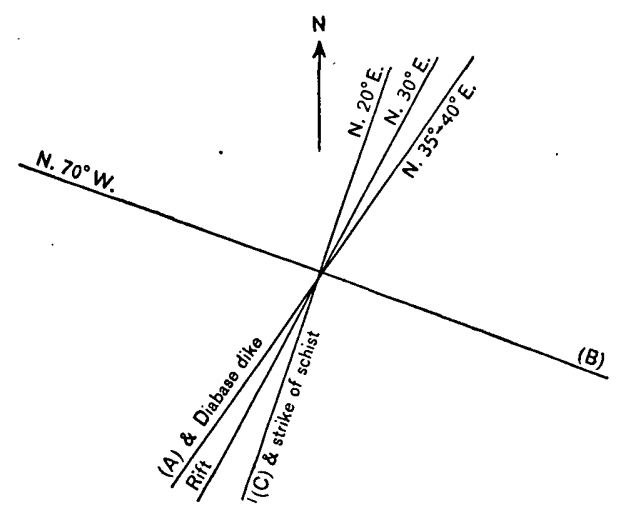

Figure 19.--Structure at Barney quarry, Barre.

(B) $\operatorname{dip} 80^{\circ} \mathrm{N} \cdot 20^{\circ} \mathrm{E}$., one only on southeast wall; (C) $\operatorname{dip} 40^{\circ}$ N. $70^{\circ}$ W., discontinuous, two near northeast wall, slickensided in direction of dip. There is a basic dike, up to 2 feet thick, at the south corner back of heading (A). The rock within the heading is crossed by horizontal subjoints 1 to 3 inches apart, due to the dike. On the northwest wall the granite is in contact with schist that has a foliation striking N. $20^{\circ} \mathrm{E}$. and dipping steeply west. There is a pegmatite dike or lens along the schist contact, and the granite for a space of 15 feet from the contact is coarse and fine in alternating bands. There is also an inclusion of schist at the north corner, 15 feet by 1 foot, with a foliation striking $\mathrm{N} .80^{\circ} \mathrm{E}$.

The plant comprises a horse derrick, a steam rock drill, and a steam pump.

Transportation is by cart, $3 \frac{1}{2}$ miles to Barre.

The product is used for monuments.

CANTON QUARRY.

The Canton quarry is about 450 feet east-northeast from the Bond $\&$ Whitcomb quarry, and northeast of the top of Millstone Hill, in Barre. (See Pl. I, No. 21.) Operator, Barre Granite and Quarry Company, Barre, Vt. 
The granite, "medium and light Barre," is a biotite granite of medium and light bluish-gray shade, like those already described.

The quarry is estimated as measuring about 300 feet in a northeasterly direction by 200 feet across, and from 35 to 60 feet in depth.

The sheets, from 1 to 14 feet thick, are normal and dip N. to $10^{\circ}$. There are two sets of joints: (a), striking N. $37^{\circ} \mathrm{W}$. and dipping $80^{\circ}$ N. $53^{\circ}$ E., forms the east wall, and a heading on the west wall, and is spaced 5 to 50 feet; (b), striking N. $35^{\circ} \mathrm{E}$., dipping $55^{\circ} \mathrm{S} .55^{\circ} \mathrm{E}$., is spaced 10 to 25 feet and 200 feet, and is slickensided in the direction of dip. The rift is reported as vertical with N. $42^{\circ} \mathrm{E}$. course and the grain as horizontal. There are two quartz veins up to $1 \frac{1}{2}$ inches thick, one along heading (a), another in the middle of the quarry. A marked east-west compressive strain is shown in the faulting of channel cores as illustrated in figure 2.

The plant consists of two derricks, a four-drum hoisting engine, an air compressor (capacity 675 cubic feet of air per minute), four large rock drills, seven air plug drills, and two steam pumps.

Transportation is by siding. (See Pl. I.)

The product is used for monuments. Specimen: The soldiers' monument at Trenton, N. J.

O'HERIN QUARRY.

The O'Herin quarry is about 500 feet N. $35^{\circ} \mathrm{E}$. of the Barney quarry, and in about that direction from the top of Millstone Hill, in Barre. (See Pl. I, No. 22.) Operators, Robert O'Herin \& Co., Websterville, Vt.

The granite, "light Barre," is a biotite granite of light-gray shade like that previously described.

- The quarry, opened in 1904, is estimated as measuring about 300 feet in a $\mathrm{N} .22^{\circ} \mathrm{E}$. direction by 150 feet across, and from 10 to 30 feet in depth.

The sheets, from 1 to 8 feet thick, are normal and dip very low southeast. There are two sets of joints: (a), striking N. $15^{\circ} \mathrm{E}$., vertical, and dipping $55^{\circ} \mathrm{E}$. on the southeast and northeast walls, is spaced 10, 20, to 100 feet; (b), striking N. $30^{\circ}$ to $35^{\circ}$ W., dipping $75^{\circ}$ $\mathrm{N} .60^{\circ} \mathrm{E}$. and vertical, is discontinuous, one on and one near the south wall. The rift is reported as vertical with N. $30^{\circ} \mathrm{E}$. course and the grain as horizontal.

The plant comprises one horse derrick, a large rock drill, an air plug drill, and a steam pump. Compressed air is obtained from the Barre Granite and Quarry Company.

Transportation is by cart, $3 \frac{1}{2}$ miles to Barre.

The product is used for monuments and buildings. 
WALKER QUARRY.

The Walker quarry is east-southeast of the O'Herin quarry, and N. $40^{\circ}$ E. from the top of Millstone Hill, in Barre. (See Pl. I, No. 23.) Operators, George Walker \& Sons, Barre, Vt.

The granite, "medium Barre," is a biotite granite of medium gray shade and fine texture like that already described.

The quarry, opened in 1902, is estimated as measuring about 150 feet in a N. $30^{\circ} \mathrm{E}$. direction by 80 feet across and 30 feet in depth.

The sheets, from 1 foot to 8 feet 10 inches thick, are normal and dip gently east and northeast. There are two sets of joints: (a), striking N. $25^{\circ}$ W., vertical, forming east and west walls only; (b), striking $\mathrm{N} .40^{\circ} \mathrm{E}$., and vertical, adjacent to the dike. The rift is reported as vertical with $\mathrm{N} .50^{\circ} \mathrm{E}$. course and the grain as horizontal. A 12-inch basic dike, the continuation of that in Barney quarry, page 76, has the course of joints (b). The granite on the north side of this dike is broken into vertical scales, 1 to 6 inches thick and a foot wide.

The plant at the quarry comprises a horse derrick, a large air rock drill, two air plug drills, and an air pump. Compressed air is obtained from the Barre Granite and Quarry Company. The plant at the cutting shed in Barre includes a derrick, a hoisting engine, a 35-horsepower electric motor, and two air compressors (capacity 69 and 134 cubic feet of air per minute), two air plug drills, 25 air hand tools, a surfacer, and two polishers.

Transportation is by cart, 300 feet to rail for rough stock, but $3 \frac{1}{2}$ miles to cutting shed for stock to be finished.

The product is small monuments.

WELLS-LAMSON QUARRY.

The Wells-Lamson quarry is 640 feet above the city and about northeast from the top of Millstone Hill. (See Pl. I, No. 24.) Operator, The Wells-Lamson Quarry Company, Barre, Vt.

The granite, "light and medium Barre," is a biotite granite of light medium, slightly bluish gray shade, or of medium bluish-gray shade, and of even-grained fine inclining to medium or fine texture. It is reported as identical in quality with the "light" and "medium" of the Smith Upper and Duffee quarries described on pages 70, 71. The following result of a microscopic examination of "dark" granite from this quarry, made by Whitman Cross, of the United States Geological Survey, was published in 1898: ${ }^{a}$

Messrs. Wells, Lamson \& Co.'s dark granite is a fine, even-grained, typical granite containing two micas (biotite, muscovite) sometimes called granite proper. The constituents of importance are quartz, orthoclase, microcline, biotite, and muscovite The first three occur in wholly irregular grains interlocking in a very complex manner

$a$ See Nineteenth Ann. Rept. U. S. Geol. Survey, pt. 6, continued, 1898, p. 224. 
The micas are in small leaves between and penetrating the other minerals to some extent. Muscovite apparently occurs in two forms, one corresponding to the biotite, -as seemingly primary, and the other in small flakes in the orthoclase, and clearly a secondary mineral. Accessory constituents are oligoclase, albite (?), titanite (sphene), and apatite. There is an almost total absence of magnetite or other iron ore. Biotite is slightly changed to green, and probably yields chlorite in some samples. The orthoclase gives way to an aggregate of fine muscovite leaves, also varying much in different samples, no doubt. Both quartz and biotite show that the rock has endured considerable pressure, the former by the "undulatory extinction" it exhibits, and the biotite by the curved and bent lamellæ. The pressure did not extend to a crushing of the grains or any banded structure. In the feldspars is some calcite filling small cracks. On the basis of this examination I should estimate it at quartz 30 to 35 per cent, orthoclase 30 per cent, microcline 20 to 25 per cent. Much of the iron is present in the ferrous or unoxidized condition.

A chemical analysis of the "dark" from this quarry made by William C. Day at Swarthmore College, Pennsylvania, was published in the same work and on the same page, and is repeated here for reference.

Analysis of "dark Barre" granite by William C. Day.

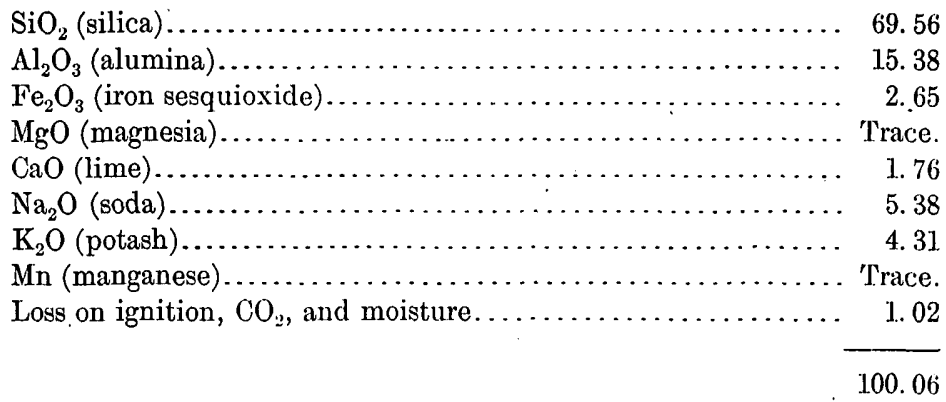

Doctor Day also made the following physical determinations of "dark" and "medium" from this quarry: ${ }^{a}$ Specific gravity, dark, 2.672 ; medium, 2.662 ; per cent of water absorbed, dark, 0.121 per cent; medium, 0.129 per cent; crushing strength, dark, 16,719 to 19,957 pounds; medium, 14,968 to 17,856 pounds.

The quarry, opened about 1885, is estimated as measuring about 400 feet in a N. $25^{\circ} \mathrm{W}$. direction by 300 feet across and from 50 to 60 feet in depth.

The sheets, from 6 inches to 15 feet thick, dip gently southeast and N. $65^{\circ} \mathrm{E}$. On the west side the lenses are very short. There is one sharply curving "toe nail" 10 feet high, intersecting the sheet structure. There are three sets of joints: (a), striking N. $65^{\circ}$ to $70^{\circ} \mathrm{E}$., dipping $40^{\circ}$ to $60^{\circ} \mathrm{N} .27^{\circ} \mathrm{W}$., is spaced 25,50 , and 200 feet; (b), striking N. $30^{\circ}$ E., vertical, forms a small heading on the south edge only; (c), striking N. $45^{\circ} \mathrm{E}$., vertical, forms a heading on the north wall and is spaced 200 feet and over. The rift is reported as 
vertical (probably N. $30^{\circ}$ E.) and the grain as horizontal. A 12-inch band of darker granite strikes N. $70^{\circ} \mathrm{E}$. and dips $60^{\circ} \mathrm{N} .20^{\circ} \mathrm{W}$, marking the direction of the flow. Schist crops out close to the south ${ }^{\circ}$ wall and continues in that direction. A north-south compressive strain is reported.

The plant comprises a 100-ton and a 50-ton derrick, a 10-ton Blondin carrier, an air compressor (capacity 160 cubic feet of air per minute), six large rock drills, six air plug drills, and a steam pump.

Transportation is by siding, as shown on Plate $\mathrm{I}$.

The product is used for monuments and buildings.

PRUNEAU QUARRY.

The Pruneau quarry is N. $75^{\circ} \mathrm{E}$. from the top of Millstone Hill, in Barre. (See Pl. I, No. 25.) Operators, Pruneau \& Co., Websterville, Vt.

The granite, "dark medium," is a biotite granite of medium bluish-gray shade and fine texture, in composition like those already described.

The quarry is estimated as measuring about 200 feet in a northwest direction by 200 feet across and from 30 to 45 feet in depth.

The sheets, from 6 inches to 9 feet thick, but thin for 10 feet down, are normal and dip $15^{\circ}$ to $25^{\circ} \mathrm{SSE}$. There are three sets of joints: (a), striking N. $10^{\circ}$ to $15^{\circ} \mathrm{E}$., dipping $65^{\circ} \mathrm{S} .78^{\circ} \mathrm{E}$., forms a heading in the south half of the quarry, and is spaced 5 to 30 feet; (b), striking N. $60^{\circ}$ E., dipping $60^{\circ} \mathrm{N} .30^{\circ} \mathrm{W}$., forms the south wall and a 4 -foot heading in the north half. It is slickensided in the direction of dip; (c), striking N. $65^{\circ} \mathrm{W}$., vertical, usually crosses one sheet only. A heading of (a) is coated with a slickensided mass up to 1.75 inches thick, largely of coarse muscovite scales with some kaolinized feldspar, possibly of pegmatitic origin. The rift is reported as vertical with N. $30^{\circ} \mathrm{E}$. course and grain as horizontal. A one-half inch quartz vein strikes N. $12^{\circ}$ E. Several schist inclusions at the top of the northwest wall measure up to 8 by 2 feet.

The plant consists of a derrick and hoisting engine, hand derrick, small air compressor, large rock drill, three air plug drills and a steam pump.

Transportation is by cart, $3 \frac{1}{2}$ miles to Barre.

The product is used for monuments.

$$
\text { CONSOLIDATED MARR \& GORDON QUARRY. }
$$

The Consolidated Marr \& Gordon quarry is 860 feet above the city and $\mathrm{N} .75^{\circ} \mathrm{E}$. from the top of Millstone Hill, in Barre. (See Pl. I, No. 26.) Operator, Consolidated Quarry Company, Barre, Vt. 
The granite, "light Barre," is a biotite granite of light medium slightly bluish shade like that of the Wetmore \& Morse and Smith Upper quarries, and of even-grained fine inclining to medium texture. (See p. 70.)

The quarry is estimated as measuring about 300 feet from north to south by as much across, and from 50 to 70 feet in depth.

The sheets, from 1 to 15 feet thick, the thicker ones generally 5 to 10 feet, in places irregular, dip $15^{\circ} \mathrm{E}$. There are four sets of joints, as shown in figure 20: (A) dips $35^{\circ} \mathrm{N} .40^{\circ} \mathrm{W}$., one on the west wall, and a heading at the southeast corner; (B) dips $75^{\circ} \mathrm{W}$., one at the southeast corner; (C) dips $50^{\circ}$ to $80^{\circ} \mathrm{N} . .20^{\circ} \mathrm{W}$., forms north and south walls and small heading 30 feet west of the south wall; (D) dips $75^{\circ} \mathrm{N} .60^{\circ}$ E., one crosses the quarry from the northeast corner. The rift is reported as vertical and the grain as horizontal.

The plant consists of three derricks, two hoisting engines, an air compressor (capacity 600 cubic feet of air per minute), three large rock drills, three smaller ones, seren air plug drills, and a steam pump.

Transportation is by siding, as shown in Plate I.

The product is used for monuments, but stones with only one clear face go into buildings.

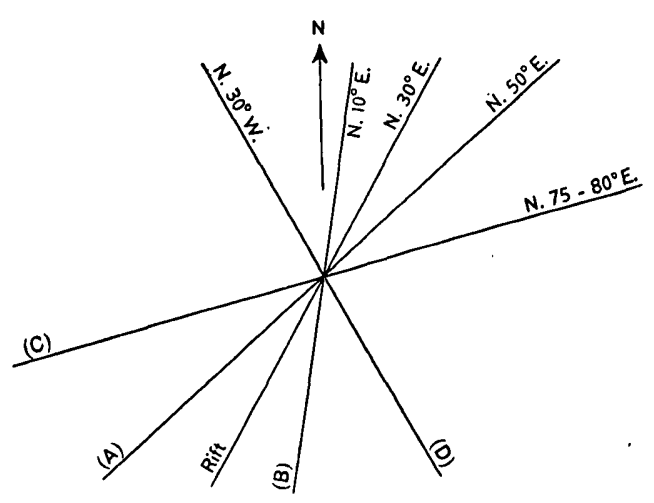

Figure 20.-Structure at Consolidated Marr \& Gordon quarry Barre.

M'DONALD \& CUTTER QUARRY.

The McDonald \& Cutter quarry is east-northeast of top of Millstone Hill, east of the main street of Websterville, in Barre. (See Pl. I, No. 27.) Operator, Consolidated Quarry Company, Barre, Vt.

The granite of this and the four adjoining quarries of this firm is mostly "light Barre" with some "medium." It is a biotite granite of light medium or medium, slightly bluish-gray shade and of evengrained fine inclining to medium texture, like those described on pages 65,71 .

The quarry is estimated as measuring about 200 feet in a N. $22^{\circ}$ W. direction by 175 feet across and from 65 to 110 feet deep.

The sheets, in places imperfectly developed, from 3 to 30 feet thick, undulate horizontally. There are masses 40 feet thick without sheets. There are three sets of joints: (a), striking N. $10^{\circ}$ to $15^{\circ}$ W.; vertical, forms the east and west walls and is spaced 10 to 30 
feet; (b), striking N. $40^{\circ}$ to $45^{\circ} \mathrm{E}$., vertical, is spaced 1 to 30 feet; (c) forms an irregular rusty heading at the northeast end, striking N. $15^{\circ}$ E. and dipping $70^{\circ}$ E., but undulating along the strike. "Sap" is up to 14 inches thick.

The plant of this and the four adjoining quarries of this firm comprises seven derricks, two. Blondin carriers, nine hoisting engines, an air compressor (capacity 730 cubic feet of air per minute), seventeen large rock drills, twenty-eight air plug drills, and six steam pumps.

Transportation is by siding, as shown on Plate I.

The product is used for monuments, but stones with only one clear face are used for buildings.

INNES \& CRUIKSHANK QUARRY.

The Innes \& Cruikshank quarry is about 100 feet north-northeast' of the last. (See Pl. I, No. 28.) Operator, Consolidated Quarry Company, Barre, Vt.

For the granite, see under that of the McDonald \& Cutter quarry (p. 79).

The quarry is estimated as measuring about 350 feet in a northnortheast direction by 250 feet across and 90 feet in depth.

This is a "bowlder" quarry. The sheets, 2 to 12 feet thick, dip $45^{\circ} \mathrm{NW}$., but some in the northeast part dip $25^{\circ} \mathrm{E}$. and $35^{\circ} \mathrm{NW}$. There are two sets of joints: (a), striking N. $80^{\circ}$ to $85^{\circ}$ E., dipping $50^{\circ}$ to $70^{\circ} \mathrm{S} .20^{\circ} \mathrm{E}$., forms the southeast and part of the northwest walls, and is spaced $10,30,50$, and 200 feet; (b), striking eastwest, dipping $35^{\circ} \mathrm{S}$., one only on southeast side. The rift is reported as vertical with $\mathrm{N} .30^{\circ} \mathrm{E}$. course and the grain as horizontal to $15^{\circ}$ NW. Owing to erosion there is no parallelism here between the rock surface and sheet structure. Sand up to 2 inches thick occurs between the sheets, and the joints are also generally loose. The "sap" is from 6 to 16 inches thick.

For transportation and product, see those of the McDonald \& Cutter quarry (above).

CAPITAL QUARRY.

The Capital quarry is 750 feet south-southeast of the McDonald \& Cutter quarry and southeast of Millstone Hill, in Barre. (See Pl. I, No. 29.) Operator, Consolidated Quarry Company, Barre, Vt.

For the granite, see under that of the McDonald \& Cutter quarry (p. 79).

The quarry is estimated as measuring 150 feet in a northeast direction by 100 feet across and 50 feet in depth.

This is a "bowlder" quarry. The sheets, from 6 inches to 4 feet thick, but extending to a depth of only 20 feet, dip about $10^{\circ} \mathrm{SE}$. 
There are three sets of joints: (a), striking N. $65^{\circ}$ E., dipping $55^{\circ} \mathrm{S}$. $25^{\circ} \mathrm{E}$., spaced 3 to 10 feet, on south side only; (b), striking N. $35^{\circ}$ E., dipping steep N. $55^{\circ}$ W., is discontinuous; (c), striking NW., dipping $70^{\circ} \mathrm{NE}$., is spaced 5 to 20 feet. A basic vertical dike, 2 to 6 feet thick, with northeast course, forms the northwest wall. It weathers spheroidally. The rift is reported as varying in different blocks.

For the plant, transportation, and product, see those of the McDonald \& Cutter quarry (p. 80).

COUYELLARD QUARRY.

The Couyellard quarry is about 200 feet southeast of the McDonald \& Cutter quarry and southeast of the top of Millstone Hill, in Barre. (See Pl. I, No. 30.) Operator, Consolidated Quarry Company, Barre, Vt.

For the granite, see under that of the McDonald \& Cutter quarry (p. 79).

The quarry is estimated as measuring about 275 feet in a N. $70^{\circ}$ E. direction by 200 feet across, and from 50 to 70 feet in depth.

This is a "bowlder" quarry. Sheet structure is hardly present. There are masses 20 feet thick. There are three sets of joints: (a), striking $\mathrm{N} .75^{\circ} \mathrm{E}$., dipping $65^{\circ} \mathrm{S}$. $15^{\circ} \mathrm{E}$., forms the north and south walls and one joint in the center; (b), striking northwest, dipping $45^{\circ} \mathrm{NE}$., is spaced 5 to 20 feet and over; (c), striking N. $30^{\circ} \mathrm{E}$., dipping $65^{\circ} \mathrm{N} .60^{\circ} \mathrm{W}$. to $90^{\circ}$, forms a heading at the east corner, and is spaced 5 to 40 feet and over. The rift is reported as vertical with $\mathrm{N} .55^{\circ}$ to $60^{\circ} \mathrm{E}$. course, and the grain as horizontal.

The plant, transportation, and product are given in connection with the McDonald \& Cutter quarry (p. 80).

M'IVER \& MATHESON QUARRY.

The McIver \& Matheson quarry is about 1,500 feet east-southeast of the Websterville main street, and in same direction from the top. of Millstone Hill, in Barre. (See Pl. I, No. 31.) Operators, McIver \& Matheson, Barre, Vt.

The granite, "light and medium Barre," is a biotite granite of light medium and medium bluish-gray shade, and of even-grained fine inclining to medium texture like that described on pages 65,71 .

The quarry is estimated as measuring about 250 feet in a northeast direction by 200 feet across and from 30 to 65 feet in depth.

This is a "bowlder" quarry. The sheet structure is very irregular, owing to "growing on." There are two sets of joints: (a), striking northwest, vertical, forms a 15 -foot wide heading across the middle of the quarry, and is spaced 4 to 44 feet; (b), striking N. $40^{\circ}$ E., ver4782-Bull. 404-09-6 
tical, is spaced 10 to 50 feet. A diabase dike, the continuation of that in Jones Light quarry (p. 56), is here 9 feet thick, vertical and parallel to joint (b). The granite for a foot next to the dike breaks off in vertical scales, 1 to 6 inches thick. The rift is reported as vertical with N. $40^{\circ} \mathrm{E}$. course and the grain as horizontal. Rusty stain is 12 inches thick along joint and some sheet faces.

The plant includes a derrick and hoisting engine, a large rock drill and a steam pump.

- Transportation is by cart, either 4 miles to Barre or a few hundred feet to a siding at an adjoining quarry.

The product is used for monuments. Specimens: The Governor Goebel monument in Kentucky and the Holthaus monument at St. Louis, Mo.

\section{MANUFACTURERS' QUARRY.}

The Manufacturers' quarry, south of and adjoining the last, is in Barre. (See PI. I, No. 32.) Operator, Manufacturers' Quarrying Company, Barre, Vt.

The granite, "medium Barre," is a biotite granite of medium bluishgray shade and of even-grained fine texture. (See p. 71.)

The quarry is estimated as measuring 250 feet in a northwest direction by 200 feet across and from 50 to 60 feet in depth.

This is a "bowlder" quarry. The sheets, in places 1 to 10 feet thick, die out laterally in the center of the quarry, so that masses 30 feet thick can be obtained at the same level as thin-sheeted ones. There are three sets of joints: (a), striking N. $40^{\circ} \mathrm{W}$, vertical, is spaced 8 to 30 feet; (b), striking N. $80^{\circ}$ E. to $80^{\circ} \mathrm{W}$., dipping $75^{\circ} \mathrm{S}$. and $90^{\circ}$, is spaced 30 feet and over; (c), striking N. $15^{\circ}$ E., vertical, is spaced 30 to 100 feet. The rift is reported as vertical, with N. $50^{\circ}$ to $60^{\circ} \mathrm{E}$. course, and the grain as horizontal. There are three schist inclusions on the southeast wall, measuring 25 by 10 by 10 feet; 20 by 8 by 8 feet; and 3 by 2 feet. The foliation of the largest strikes N. $30 \mathrm{~W}$. The schist is injected with minute dikes of granite and the granite within 7 feet of the inclusion is slightly darker. One of the (a) joints is coated with quartz over an inch thick with large scales of muscovite probably of pegmatitic origin. Rusty stain is 12 inches thick on sheet surface, but 24 inches on joint faces.

The plant comprises a 30-ton derrick, a hoisting engine, a Blondin carrier and engine, a small air compressor, three large rock drills, seven air plug drills, and a steam pump.

Transportation is by siding, as shown on Plate I. The product is monumental granite, but the waste is used for paving and curbing. 
The Barre quarry is N. $40^{\circ} \mathrm{E}$. from the McIver \& Matheson quarry, 800 feet northeast of the southern road from East Barre to Websterville, and about four-fifths of a mile east of the top of Millstone Hill, in Barre. (See Pl. I, No. 33.) Operator, Barre Quarry Company, Barre, Vt.

The granite, "light and medium Barre," is a biotite granite of light medium and medium bluish-gray shade and even-grained fine inclining to medium texture. Its feldspars are slightly more bluish than those of the corresponding shades from the other quarries.

The quarry, opened in 1905, measures about 100 by 60 feet and 30 feet in depth.

This is a "bowlder" quarry, without sheet structure. There are two sets of joints: (a), striking N. $30^{\circ}$ E., vertical; (b) striking N. $65^{\circ}$ to $75^{\circ} \mathrm{E}$., dipping $40^{\circ}$ to $50^{\circ} \mathrm{S} .25^{\circ} \mathrm{E}$., forms the north and south walls and is spaced 3 to 50 feet. The rift is reported as varying in different blocks. Biotitic knots are 1.5 by 0.5 inches. There is "sap" up to 6 inches thick on joint faces.

The plant comprises a derrick, an electric motor, an air compressor (capacity 200 cubic feet of air per minute), and a steam pump.

- Transportation is by cart, over 4 miles to Barre.

The product is used for monuments and buildings.

MILNE QUARRY.

The Milne quarry is on the south side of the southern road from Websterville to East Barre and about nine-tenths of a mile eastsoutheast of top of Millstone Hill, in Barre. (See Pl. I, No. 34.) Operator, Alexander Milne, Barre, Vt.

The granite, "light and medium Barre," is a biotite granite of light medium and medium bluishgray shade, and of evengrained fine inclining to medium texture. (See pp. 65,71 .)

The quarry is esti-

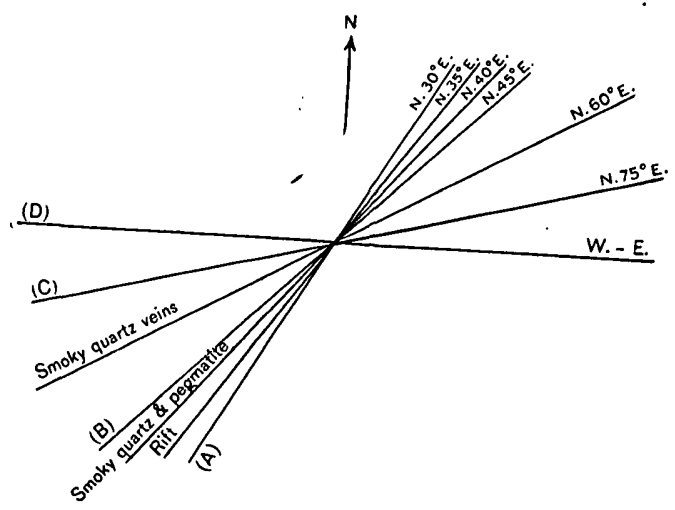

FiguRE 21.-Structure at Milne quarry, Barre. mated as measuring about 250 feet in a north-northwest direction by 250 feet across and from 55 to 70 feet in depth. 
The sheets, from 1 to 6 feet thick, are about horizontal or dip $20^{\circ}$ E., but disappear 25 feet below the rock surface, where low-dipping joints (D) are used by the quarrymen instead. There are four sets of joints, as shown in figure 21: (A), vertical, dipping $20^{\circ}$ and $40^{\circ} \mathrm{N}$. $60^{\circ} \mathrm{W}$., forms the east-southeast wall, is spaced 3 to 150 feet, coated with coarse scales of muscovite; (B), dipping $40^{\circ}$ northwest, discontinuous, is spaced 15 to 150 feet; (C), dipping $70^{\circ} \mathrm{S} .15^{\circ} \mathrm{E}$., is spaced 2 to 20 feet and over, but stops 20 feet down; (D), dipping $75^{\circ} \mathrm{S}$., one only, at the south corner. The rift is reported as vertical with N. $35^{\circ} \mathrm{E}$. course and the grain as horizontal. There are veins of smoky quartz up to 2 inches thick in the south corner, at intervals of about 3 feet, dipping $60^{\circ} \mathrm{S} .40^{\circ} \mathrm{E}$. Some with another strike are part pegmatite. The microscopic structure of this quartz has been described on page 55 .

The plant comprises two derricks, a hoisting engine, an air compressor (capacity 200 cubic feet of air per minute), four large rock drills, six air plug drills, and a steam pump.

Transportation is by cart, over 4 miles to Barre.

The product is used for monuments and buildings.

BARRE MEDIUM QUARRY.

The Barre Medium quarry is about 500 feet southeast of the Milne quarry. (See Pl. I, No. 35.) Operator, Barre Medium Granite Company, Barre, Vt.

The granite, "medium and light Barre," is a biotite granite of medium and light medium bluish-gray shade and even-grained fine inclining to medium texture like that described on pages 65 and 71 .

The quarry, opened in 1906 , is estimated as measuring 200 feet north-south by 150 feet across and from 10 to 25 feet in depth.

Sheets from 6 inches to 5 feet thick, increasing in thickness downward, dip low southeast. No joints have yet been found. The rift is reported as vertical with $\mathrm{N} .60^{\circ} \mathrm{E}$. course, and the grain as horizontal. Rusty stain is up to 4 inches thick on sheet surfaces.

The plant comprises a derrick, a hoisting engine, an air compressor driven by a 20-horsepower engine, two large rock drills, four air plug drills, and a steam pump.

Transportation is by cart, over 4 miles to Barre.

The product is used for buildings and monuments. Specimen of the "light:" The trimmings in the Aldrich public library, Barre, Vt.

EMPIRE GRANITE COMPANY'S QUARRY.

The Empire Granite Company's quarry is about 800 feet eastsoutheast of the Milne quarry on the north side of the southern road from Websterville to East Barre. (See Pl. I, No. 36.) Operator, Empire Granite and Quarrying Company, Northfield, Vt. 
The granite, "light and medium Barre," is a biotite granite of light medium and medium, slightly bluish-gray shade, and of even-grained fine inclining to medium texture. (See pp. 65, 71.)

The quarry, opened about 1889 , is estimated as about 375 feet by 200 and from 10 to 50 feet deep.

The sheets are normal, from 1 to 16 feet thick, dipping $10^{\circ} \mathrm{SE}$. There are two sets of joints: (a), striking N. $70^{\circ}$ E., dipping $53^{\circ} \mathrm{S}$. $20^{\circ} \mathrm{E}$., is spaced 10 to 50 feet and over; (b), striking northwest, dipping $75^{\circ} \mathrm{SW}$., discontinuous, is spaced 100 feet and over. The rift is reported as vertical with N. $35^{\circ} \mathrm{E}$. course and the grain as horizontal. The "sap" is up to 3 inches thick. At a smaller opening (not being worked) the sheets dip about $10^{\circ} \mathrm{N} .60^{\circ} \mathrm{E}$. and are also normal.

The plant comprises two derricks and two hoisting engines, an air compressor (capacity 650 cubic feet of air per minute), two large rock drills, five air plug drills, and a steam pump.

Transportation is by cart, over 4 miles to Barre.

The product is used for monuments and buildings.

STRATTON QUARRY.

The Stratton quarry is 400 feet east of the last, and about $1 \frac{1}{4}$ miles east-southeast of the top of Millstone Hill, in Barre. (See Pl. I, No. 37.) Operator, George Stratton Quarry Company, Barre, Vt.

The granite, "light and medium Barre," is a biotite granite of light medium and medium gray shade, and of even-grained fine inclining to medium texture like that previously described.

- The quarry, opened in 1905 , measures about 100 feet square and averages 10 feet in depth.

The sheets, from 1 to 5 feet thick, vary from horizontal to a dip of $10^{\circ}$ about south. There is but one set of joints, which strikes $\mathrm{N}$. $65^{\circ} \mathrm{E}$., dips $55^{\circ} \mathrm{S} .25^{\circ} \mathrm{E}$., and is spaced 1 to 20 feet. The "sap" is 6 inches thick and under.

The plant consists of one horse derrick.

Transportation is by cart, over 4 miles to Barre.

The product is used for buildings and monuments.

JONES DARK QUARRY.

The Jones Dark quarry is in Williamstown (Orange County), but adjoins the Empire quarry in Barre. (See Pl. I, No. 38.) Operators, Jones Brothers \& Co., Barre, Vt.

The granite (specimen D, XXIX, 13, a), "dark Barre," is a biotite granite of dark bluish-gray shade, a trifle darker than that of the Bruce quarry, and of even-grained fine inclining to medium texture with feldspars up to 0.3 inch and mica to 0.1 inch. Its constituents 
are identical with those of the Milne \& Wylie quarry stone described on page 59. It effervesces with cold dilute muriatic acid.

The polished face shows pyrite and a little magnetite. The polish is fair. Its cut hard-way face is as light as that of the "light Barre," and thus in marked contrast to its polished face. Its mineral contrasts and qualities are identical with those of the Milne \& Wylie quarry stone (p. 59), but its texture, particularly its mica, appears to be a little finer.

The quarry, opened about 1886 , is estimated as measuring about 300 feet in a N. $80^{\circ}$ E. direction by 250 feet across and from 50 to 100 feet in depth.

The sheets, 2 to 20 feet thick, are irregular and undulating. There is one mass 28 feet thick. There are four sets of joints: (a), striking N. $80^{\circ} \mathrm{E}$., vertical, forms headings on north and south walls, is spaced 5 to 30 feet, and has rusty faces; (b), striking N. $15^{\circ}$ W., vertical, usually discontinuous vertically, is spaced 10,20,30, and 200 feet; (c), striking east-west, dipping $55^{\circ} \mathrm{S}$., discontinuous, one only in south part; (d), striking N. $50^{\circ}$ to $55^{\circ}$ E., dipping $37^{\circ} \mathrm{S} .37^{\circ} \mathrm{E}$., forms a small heading north of the south wall. The rift is reported as vertical, with course of about N. $55^{\circ} \mathrm{E}$., and the grain as horizontal. A schist inclusion in the west wall is 30 feet long with a foliation striking N. $50^{\circ} \mathrm{E}$. There are also masses of darker granite of roundish outline up to 3 feet in diameter, like those in the Marr \& Gordon quarry (p. 62). Rusty stain is up to 6 inches thick on sheet surfaces.

The plant comprises a 20 -ton and a 30 -ton derrick, two hoisting engines, an air compressor (capacity 700 cubic feet of air per minute), four large rock drills, 12 air plug drills, and two steam pumps.

Transportation is by siding to the cutting shed at Barre, which is on another siding. (See Pl. I.)

The product is monumental granite. Specimens are included in the list on page 67 .

JONES SMALL DARK QUARRY.

Jones Small Dark quarry is over 100 feet S. $20^{\circ} \mathrm{W}$. from the last, in Williamstown. (See Pl. I, No. 39.) This is an old opening which was being worked anew in 1907. Operators,. Jones Brothers \& Co., Barre, Vt.

The granite is identical with that of the last quarry. The sheets are very irregular. Joints (A) and (B) of the other quarry recur. There is a schist inclusion, 4 by 2 feet in the north wall. The darker granite also occurs here, but associated with irregular masses of aplite (specimen D, XXIX, 14, a) of light medium bluish-greenish gray color, and very fine even-grained texture described more fully on page 55 . 
PIRIE QUARRY.

The Pirie quarry is in Williamstown (Orange County), nearly $1 \frac{1}{2}$ miles south-southwest of the top of Millstone Hill. (See Pl. I, No. 40.) Operator, James K. Pirie, Graniteville, Vt.

The granite, "dark Barre," is a biotite granite of dark, slightly bluish gray shade and of even-grained fine inclining to medium texture like that of the Barre quarries described on page 58.

The quarry, opened in 1882, is estimated as measuring 350 feet in a northeast direction by 100 and 250 feet across, and from 30 to 100 feet in depth.

The sheets are normal, from 1 to 12 feet thick, and dip $10^{\circ}$ to $30^{\circ}$ NNW. Joint, rift and dike courses are shown in figure 22 . Joint set (A) dips $60^{\circ} \mathrm{S} .27^{\circ} \mathrm{E}$., forms part of the west wall, and a rusty heading across the center of quarry; (B) dips $55^{\circ} \mathrm{S} .55^{\circ} \mathrm{E}$., forms the east wall, is spaced 1 to 20 and over 50 feet. This is also very rusty; (C) dips $55^{\circ} \mathrm{E}$., only three, spaced 10 feet; (D), about vertical, discontinuous, is spaced 30 feet. The rift is reported as vertical and the grain as dipping about $35^{\circ} \mathrm{N} .30^{\circ} \mathrm{W}$. A 3 foot 6 inch pegmatite dike dipping $65^{\circ} \mathrm{S}$. $25^{\circ}$ E. crosses the center of the quarry and sends out tapering branches up to a foot in length. (See,

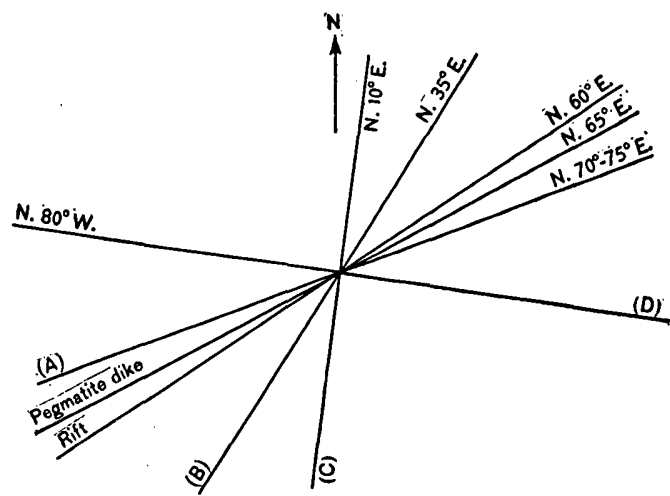

Figure 22.-Structure at Pirie quarry, Williamstown, near Barre. further, p. 55.) "Sap" up to a foot thick is mostly confined to the underside of sheets.

The plant comprises four derricks, four hoisting engines, an air compressor (capacity 565 cubic feet of air per minute), four large air rock drills, 14 air plug drills, and three steam pumps.

Transportation is by siding, as shown on Plate I.

The product is used for monuments. Specimens: Soldiers and Sailors' monument, Bennington, N. Y.; columns and capitals for the Flood mausoleum, San Francisco; memorial to persons killed by flour-mill explosion, Minneapolis, Minn.

\section{WHEATON QUARRY.}

The Wheaton quarry is $2 \frac{1}{8}$ miles east of the city, 620 feet above it, and north-northwest of the top of Cobble Hill, in Barre. (See fig. 12.) Operator, Barre White Granite Company, Barre, Vt. 
The granite (specimen D, XXIX, 29, a), "white Barre," is a biotite granite of very light-gray shade (lighter than "light Barre" and as light as that of North Jay, Me.), and of even-grained medium texture, with feldspars up to 0.4 inch and mica to 0.2 inch. Its constituents, in descending order of abundance, are: Bluish translucent to milkwhite potash feldspar (orthoclase, kaolinized and micacized, with a little fresh microcline); light smoky quartz with hairlike crystals of rutile, and with cavities in sheets with rift cracks parallel to them, intersected at right angles by shorter and fewer sheets of cavities; whitish soda-lime feldspar (oligoclase-albite) more or less altered; biotite (black mica) more sparse than in "Barre granite" generally, some of it chloritized; a little muscovite or bleached biotite. Accessory: Titanite, zircon, apatite, rutile. Secondary: Calcite, largely in orthoclase, kaolin, one or two white micas, chlorite. The stone effervesces with cold dilute muriatic acid.

This is a constructional granite of very light shade, medium texture, and strong mineral contrasts.

The quarry is estimated as about 325 feet north-south by 325 feet across and from 5 to 20 feet deep. It. was opened on a surface rising 50 feet in 325 .

The sheets, 1 to 4 feet thick and normal, dip $10^{\circ} \mathrm{NW}$. and NNE. There are two sets of joints: (a), striking, N. $70^{\circ}$ to $85^{\circ}$ E., vertical, is spaced 2 to 200 feet and over; (b), striking N. $20^{\circ}$ E., vertical, forms a heading on the south side.

The plant comprises a derrick and hoisting engine and two smaller hand and horse derricks.

Transportation is by cart, $2 \frac{1}{2}$ miles to Barre.

The product was used for buildings and the bases of monuments.

The quarry not operated in July, 1907.

WILDBUR QUARRY.

The Wildbur quarry is on the west side of Cobble Hill, 600 feet above the city and N. $35^{\circ} \mathrm{E}$. from the top of Millstone Hill, in Barre. Operators, Wildbur Brothers \& Bessey, Barre, Vt.

The granite (specimen D, XXIX, 31, a), "light Barre," is a biotite granite of light medjum gray shade (like Jones "light Barre") and of even-grained fine inclining to medium texture, with feldspars up to 0.2 inch and mica to 0.1 inch. The mica is finer and more abundant than in the stone of Wheaton quarry. Its constituents are identical with those of Jones "light Barre" described on page 65. A clear microcline incloses an altered orthoclase. The quartz shows effects of strain and conspicuous rift cracks parallel to or coinciding with sheets of cavities. Some of these cracks polarize brightly and continue into the feldspars, where they are clearly filled with fibrous muscovite. The stone effervesces with cold dilute muriatic acid. 
The quarry is estimated as measuring 100 feet east-west by 75 feet across. It has a working face 80 feet high on the east.

The sheets, 1 to 8 feet thick, becoming thicker eastward, appear to belong to the outside of an arch or dome striking here N. $10^{\circ}$ to $20^{\circ}$ W. and dipping $60^{\circ} \mathrm{S} .75^{\circ} \mathrm{W}$. One set of joints only, striking N. $75^{\circ} \mathrm{E}$. and dipping $70^{\circ} \mathrm{S} .15^{\circ} \mathrm{E}$., is spaced 8 to 30 feet and over. The rift is reported as vertical, with N. $75^{\circ}$ E. course, and the grain as horizontal.

The plant consists of a derrick and hoisting engine.

Transportation is by cart, 3 miles to Barre.

The product is used for monuments and buildings.

BIANCHI QUARRY.

The Bianchi quarry is on the west side of Cobble Hill near its southwest end, about 600 feet above the city (southwest to Bond \& Whitcomb quarry on Millstone Hill), in Barre. Operator, Charles B. Bianchi, East Barre, Vt.

The granite, "light Barre," is a biotite granite of light medium gray shade and of even-grained fine inclining to medium texture, identical with that of the Wildbur quarry (p. 88).

The quarry measures about 70 feet north-south by 60 feet across, and has a high working face on the east.

The sheets, 10 to 18 feet thick, strike N. $40^{\circ}$ W., and dip $35^{\circ} \mathrm{S}$. $50^{\circ} \mathrm{W}$. There are two sets of joints: (a), striking N. $50^{\circ}$ E., vertical, is spaced 1 to 20 feet; (b), striking N. $30^{\circ}$ W., vertical, discontinuous, is spaced 10 to 30 feet. The rift is reported as vertical with N. $50^{\circ} \mathrm{E}$. course and the grain as horizontal. Flow structure shown by vertical biotitic planes strikes about north. A basic dike, up to 6 inches thick, crosses the center of the quarry with N. $55^{\circ} \mathrm{E}$. course.

The plant consists of a horse derrick. The firm has a cutting plant in Barre, which receives granite mostly from other quarries.

Transportation is by cart, 3 miles to Barre.

The product is used for bases and hammered monumental work.

HYLAND QUARRY.

The Hyland quarry is in Barre, on the west side of Cobble Hill, a little north of the Wildbur quarry and at the same level. It was just being opened in July, 1907.

Besides the above quarries a number of openings shown on the quarry map (Pl. I) were either temporarily or permanently abandoned in 1907. 
САBOT.

The town of Cabot adjoins that of Woodbury on the southeast and of Walden on the northeast. Lambert's prospect is in thenorthern corner of the township, on the east side of a north-south ridge, roughly about 4 miles east of Robeson Mountain in Woodbury and about 700 feet above Woodbury Pond. (See fig. 1.) It is on the farm of Myron Goodnough, near the Walden line, on the South Walden road which leads from Cabot to Hardins. Operator, Joseph Lambert, Macksville, Hardwick, Vt.

The granite (specimen D, XXIX, 59, a), dark gray, is a quartz monzonite of dark bluish gray color (as dark as "dark Barre") and of even-grained fine texture, with feldspars and mica up to 0.2 inch, the latter rarely 0.3 inch. Its constituents, in descending order of abundance, are: Clear quartz with fluidal and other cavities in sheets and with rift cracks parallel to them filled with fibrous muscovite and extending into the feldspars; bluish gray to milk-white soda-lime feldspar (oligoclase) but little kaolinized, micacized, and with calcite; bluish-gray potash feldspar (orthoclase, kaolinized and micacized, with microcline); greenish biotite (black mica); and a little muscovite or bleached biotite. Accessory: Pyrite, titanite, apatite, and allanite (a crystal 0.33 by 0.09 millimeter rimmed with epidote). Secondary: Calcite, epidote, kaolin, and one or two white micas. It effervesces slightly with cold dilute muriatic acid.

This stone is a little finer textured than some of the "dark Barre," and more micaceous. Its mineral contrasts are more marked owing to its feldspars being whiter and less bluish, and its quartz not smoky. It ought to hammer light.

The quarry, opened in 1904, consists of several small preliminary openings. A little work was done in 1907.

The sheets are not yet sufficiently exposed to show their thickness. There are five sets of joints: (a), striking N. $85^{\circ}$ E., dipping $75^{\circ} \mathrm{N}$.; (b), striking N. $55^{\circ} \mathrm{W}$., dipping $55^{\circ} \mathrm{S} .35^{\circ} \mathrm{W}$.; (c), striking N. $65^{\circ} \mathrm{E}$, dipping $25^{\circ}$ NNW.; (d), striking N. $5^{\circ}$ E., vertical; (e), striking $\mathrm{N}$. $60^{\circ} \mathrm{E}$. and dipping $75^{\circ} \mathrm{S} .30^{\circ} \mathrm{E}$.

\section{CALAIS.}

GENERAL STATEMENT.

The town of Calais adjoins that of Woodbury on the southwest. The quarries are at Adamant (formerly known as Sodom) in the west corner of the town and 6 miles north-northeast of Montpelier. (See fig. 1.) The quarries lie along a N. $30^{\circ} \mathrm{E}$. line on the southeast side of a granite ridge. The granite is a biotite granite of medium and light-gray shade and fine texture. Of geologic interest is the 
absence of sheet structure and the occurrence of graphite in connection with quartz veins. Schist crops out below the quarries at the village with a foliation striking N. $20^{\circ} \mathrm{E}$. and dipping $55^{\circ} \mathrm{W}$.

PATCH QUARRY.

The Patch quarry is within one-half mile of Adamant, in Calais. Operators, Patch \& Co., Montpelier, Vt.

The granite (specimen D, XXIX, 52, a) "medium gray," is a biotite granite of medium, slightly bluish gray color and of evengrained medium texture, with feldspars up to 0.3 inch, rarely 0.4 inch, and mica up to 0.1 inch. The larger feldspars are crystallized about the quartz and mica and give the stone something of a porphyritic texture. Its constituents, in descending order of abundance, are: Clear colorless potash feldspar (orthoclase, somewhat kaolinized and micacized, with microcline) with inclusions of the other constituents; clear, colorless quartz with but few cavities; bluish to milkwhite soda-lime feldspar (oligoclase-albite more or less altered); biotite (black mica); and a little muscovite or bleached biotite. Accessory: Apatite, zircon. Secondary: Kaolin, calcite, and white mica. It effervesces slightly with cold dilute muriatic acid.

This granite is of the same shade as "medium Barre" but of less bluish and more greenish tinge. Its mineral contrasts are stronger and its texture a little coarser. Its large clear feldspars give brilliancy to its rough surface.

The quarry, opened about 1893 , is estimated as measuring 250 feet from north to south by 150 feet across and from 20 to 50 feet in depth.

Sheet structure is absent. There are two sets of joints: (a), utilized as sheets in quarrying, striking $\mathrm{N} .85^{\circ} \mathrm{E}$., dipping $50^{\circ} \mathrm{S}$., is spaced 2 to 17 feet and slickensided in a southwest direction; (b), striking like (a) but dipping $40^{\circ} \mathrm{N}$. to $90^{\circ}$, is spaced 20 to 75 feet, in places discontinuous. The rift is reported as striking N. $30^{\circ} \mathrm{E}$. and dipping $50^{\circ} \mathrm{N} .60^{\circ} \mathrm{W}$., and the grain as striking and dipping as joints (a). The "sap" is 4 inches thick on joint faces. A small vein of smoky quartz parallel to joints (a) contains large limonite particles from the alteration of some iron mineral. The slickensided face of this vein is graphitic.

The plant comprises three 20-ton derricks, a hoisting engine, an air compressor (capacity 250 cubic feet of air per minute), five air plug drills, and a large rock drill.

Transportation is by cart, 7 miles to Montpelier.

The product is used for monuments and finds a market chiefly in the Middle West. 
The Lake Shore quarry is about 1,200 feet S. $32^{\circ} \mathrm{W}$. from the Patch quarry near Adamant in Calais. Operator, Lake Shore Quarry Company, Montpelier, Vt.

The granite (specimen D, XXIX, 53, a), "gray granite," is a biotite granite of light inclining to medium gray shade and of even-grained fine texture with feldspars up to 0.2 inch and mica to 0.1 inch, rarely 0.2 inch. The larger feldspars are crystallized about the quartz and mica, giving the stone something of a prophyritic texture. Its constituents are identical with those of the Patch quarry stone, except that it contains secondary epidote in particles up to 0.5 millimeter. It effervesces slightly with cold dilute muriatic acid.

This stone is a trifle darker than "light Barre" and a trifle lighter than "medium Barre." Its shade corresponds to that of the granite of Hallowell, Me., but its contrasts are stronger. Its other qualities are identical with those of the Patch quarry stone.

The quarry, opened in 1902 , is about 300 feet long in a N. $60^{\circ} \mathrm{W}$. direction by 250 feet across and from 20 to 40 feet deep.

Sheet structure is undeveloped. There are three sets of joints: (a), utilized as sheets in quarrying, striking N. $80^{\circ} \mathrm{E}$., dipping $80^{\circ} \mathrm{S}$., is spaced 1 to 18 feet; (b), striking N. $75^{\circ} \mathrm{E}$., dipping $30^{\circ} \mathrm{N} .15^{\circ} \mathrm{W}$, only two on south wall; (c), striking N. $20^{\circ}$ E., dipping $30^{\circ} \mathrm{W}$., discontinuous, at intervals of 20 feet and over. The rift is reported as having a N. $20^{\circ}$ E. course and dipping $70^{\circ}$ N. $20^{\circ}$ W. A 3-inch quartz vein is parallel to joints (a).

The plant comprises a derrick, hoisting engine, air compressor (capacity 200 cubic feet of air per minute), a large rock drill, three air plug drills, and a pulsometer pump.

Transportation is by cart, 7 miles to Montpelier.

The product is used for monuments and buildings. Specimen: The Soldiers' Memorial building, Stowe, Vt.

\section{EUREKA QUARRY.}

The Eureka quarry is about 900 feet N. $30^{\circ}$ E. from the Patch quarry, near Adamant in Calais. Operator, Eureka Granite Company (Clark Sibley), Montpelier, Vt.

The granite is presumably identical with that of the Patch quarry.

The quarry is about 350 feet from east to west by 80 feet across, with a working face on the north 105 feet high.

Incipient sheet structure is from horizontal to inclined $20^{\circ} \mathrm{S}$. There is only one set of joints, and that strikes N. $75^{\circ} \mathrm{E}$. and dips $55^{\circ}$ S. $15^{\circ}$ E.; spacing 2 to 10 feet. A quartz vein with limonite is parallel to the joints. 
The plant comprises a derrick, hoisting engine, air compressor, large rock drill, and two air plug drills.

Transportation is by cart, 7 miles to Montpelier.

The quarry was temporarily idle in 1907.

WOODBURY.

TOPOGRAPHY.

The township of Woodbury lies northeast of Calais, northwest of Cabot, and southwest of Hardwick. Its principal quarries are on the southeast flank of Robeson Mountain, about a mile east of Woodbury Center and 3 miles north-northeast of Woodbury (Sabins) Pond. (See map, fig. 8.) Robeson Mountain is a ridge about ${ }^{\circ}$ a mile long with an axis curving from N. $80^{\circ}$ E. to S. $70^{\circ} \mathrm{W}$. Its top is from 300 to 400 feet above the hollows on either side and 930 feet above Woodbury Pond and about 1,100 feet above the railroad at Hardwick. Granite has also been quarried on the ridges on the northwest and southeast sides of Buck Pond, and is now quarried on the rising ground at the head of the hollow on the north side of Robeson Mountain. This mass is continuous with the ridge southeast of Buck Pond. Granite has also been quarried on the north and northeast foot of Nichols Ledge, a bold cliff about 3 miles N. $70^{\circ} \mathrm{E}$. from Robeson Mountain and 740 feet above Woodbury Pond, in the east corner of the town east of Nichols Pond. The granite masses referred to are all within an area of about $3 \frac{1}{2}$ miles square, occupying the northeast part of the town.

GENERAI GEOLOGY.

Little is known of the geology of Woodbury. In the Vermont report of 1861 all the central and eastern part of the town appears as "calciferous mica schist." A belt of "clay slate" is represented as crossing the west part of the town in a north-northeast direction. Schist crops out on the northwest side of Robeson Mountain with a bedding strike of $\mathrm{N} .70^{\circ} \mathrm{W}$. and vertical dip and north pitch; also on the west-southwest side with a N. $67^{\circ}$ E. strike and a dip of $55^{\circ} \mathrm{N} .23^{\circ}$ W. This would indicate a synclinal structure for the schist of this mountain. Schist also crops out near the quarries on the rising land north of the mountain, and appears also to cap the ridge east of the north end of Buck Pond. This is a muscovite-quartz-biotite schist with interbedded calcareous quartzite. The contact of schist and granite on Robeson Mountain has been described on page 23. The mountain appears to be an oblong dome in structure with an eastnortheast to west-southwest axis, the sheets of which, horizontal at the top, bend over to $15^{\circ}$ to $20^{\circ}$ on the northwest and southeast sides, although in places still covered by schist. Nichols ledge is another 
conspicuous granite mass. The granite of the top is coarsely porphyritic with feldspars an inch long, but at its north and northeast foot there is a granite of very fine to fine texture, possibly a dike in the coarser. All the granite masses evidently protrude through the schist, but what parts of the intervening hollows are still occupied by schist is not determined. The foliation of a schist mass back of the Webber quarry, between Buck Pond and Robeson Mountain, strikes N. $20^{\circ} \mathrm{E}$.

"WOODBURY GRANITE."

The "Woodbury granites" are all biotite granites of more or less bluish gray shade, ranging from dark to light (one very light cream color); and in texture from very fine to medium. They fall into four kinds, but, taking account of minor differences, into nine varieties. Most of them possess in large masses one general characteristic: They carry sparse, more or less incomplete, crystals up to an inch across of clear potash feldspar formed about the other minerals. There is some parallelism between these crystals, for seen at a certain angle the cleavage planes of adjoining crystals reflect the light alike.

The granites of Robeson Mountain vary from light to medium gray shade and from medium to fine, inclining to medium, porphyritic texture. Their constituents, in descending order of abundance, are: (a) Clear to translucent bluish potash feldspar (orthoclase and microcline), rarely somewhat kaolinized, its large particles with inclusions of biotite, quartz, and soda-lime feldspar; light to medium smoky quartz with hairlike crystals of rutile and fluidal and other cavities in sheets in two rectangular sets parallel to rift and grain cracks, respectively (some of the rift cracks extend into the feldspars and are filled with fibrous muscovite); milk-white soda-lime feldspar (oligoclase to oligoclase-albite), more or less kaolinized, micacized, and with calcite and in places epidote; biotite (black mica), some of it chloritized; a little muscovite or bleached biotite. Accessory: Pyrite, titanite, zircon, apatite, rutile. Secondary: Kaolin, a white mica, epidote, zoisite, calcite, limonite. Some of the feldspars are minutely intergrown with quartz in vermicular structure.

Two estimates of mineral percentages by the Rosiwal method average as follows:

Average estimate of mineral percentages in granite of Robeson Mountain.

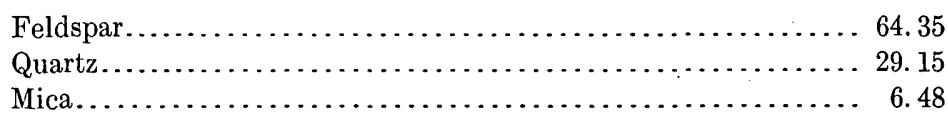

One chemical test (p. 97) shows it to contain 0.16 per cent of $\mathrm{CaO}$ (lime), soluble in warm dilute (10 per cent) acetic acid, indicating a content of 0.28 per cent of $\mathrm{CaCO}_{3}$ (lime carbonate, calcite). 


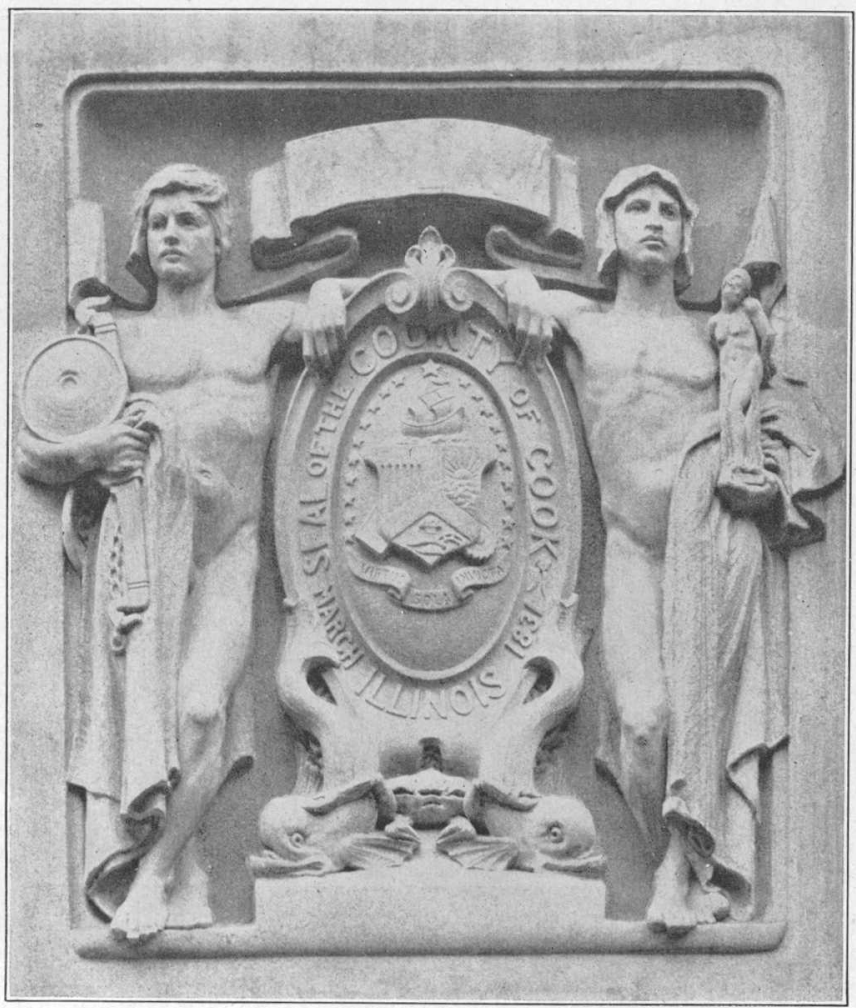

A. CARVED PANEL ( 8 BY 12 FEET) OF WOODBURY GRAY GRANITE FLANKING ENTRANCE OF COOK COUNTY COURT-HOUSE, CHICAGO.

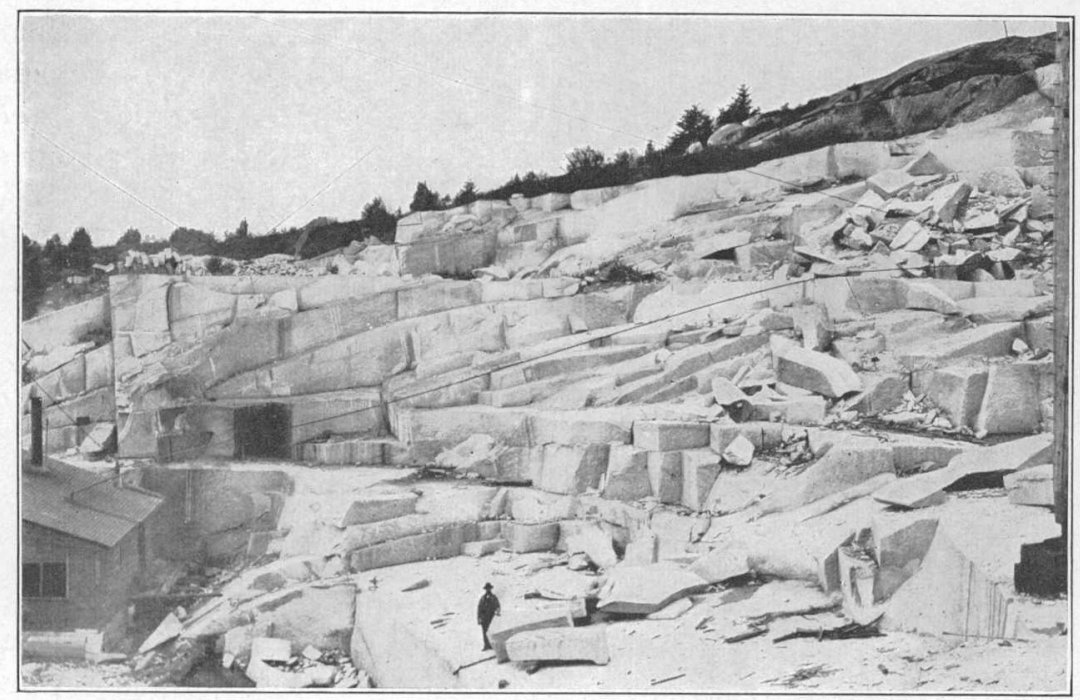

B. SHEET STRUCTURE AT FLETCHER QUARRY, ON ROBESON MOUNTAIN, WOODBURY. Looking southwest. One set of sheets curves southeasterly, dipping as high as $30^{\circ}$; another set of sheets or close joints intersects the first, dipping $5^{\circ}-10^{\circ} \mathrm{S} .70^{\circ} \mathrm{W}$. 
The general differences between the three varieties of granite on Robeson Mountain are these: In the stone from the Fletcher quarry the feldspar and quartz areas are rather large and well defined by differences of shade. In the stone from the Woodbury Lower quarry the quartz areas are finer, fewer, and less smoky. In the "Bashaw" the texture is finer and contrasts weaker than in either of the others.

The fine dark gray of the new Drenan and Webber openings and of another near Buck Pond (pp. 102-104) is of dark bluish-gray shade and fine texture, with feldspars to 0.2 inch and mica to 0.1 inch. Its composition is identical with that of the granite of Robeson Mountain, but its quartz is clear and its feldspar is albite to oligoclase-albite. Its general shade is like that of "dark Barre," but its texture is finer.

The stone from the Nichols Ledge quarry is of light inclining to medium bluish-gray shade and of very fine to fine texture, with feldspar to 0.15 and mica to 0.1 inch, with a few larger porphyritic clear feldspars. This is lighter and finer than the last. Its quartz is clear with apatite needles and its second feldspar is oligoclase to oligoclase-andesine.

Finally, there is the very light, slightly cream-colored constructional granite of the prospect between Robeson Mountain and Buck Pond (p. 103), which is of medium texture and speckled with black. Its quartz is smoky.

The minor differences, which make the varieties in the granites described above, will appear in the detailed descriptions of the stone of each quarry.

GEOLOGY OF WOODBURY QUARRIES.

The usual range in thickness of sheets is from 2 to 8 or 20 feet; the extremes are 1 to 40 feet. The double sheet structure at the Fletcher quarry has already been described on page 17 and is shown in Plate IV, $B$. The secondary, nearly horizontal, set is from 5 to 9 feet thick. It recurs in the lower part of main quarry of the Woodbury Granite Company. There is a northeast to southwest compressive strain at the Fletcher quarry near the axis of the mountain, parting and extending the upper sheets.

The joints divide themselves into six sets: (a), striking N. to N. $10^{\circ} \mathrm{E}$., with its complementary set; (b), N. $85^{\circ}$ to $90^{\circ} \mathrm{E}$.; (c), striking N. $20^{\circ}$ to $30^{\circ}$ E., with its complementary set; (d), N. $50^{\circ}$ to $65^{\circ} \mathrm{W}$.; (e), striking N. $20^{\circ}$ to $30^{\circ}$ W., with its complementary set (f), N. $60^{\circ}$ to $65^{\circ} \mathrm{E}$. The spacing of these joints ranges from 2 to 200 feet, but mostly 10 to 20 to 40 feet. Headings, 3 to 30 feet wide, of set (a) are spaced 30 to 50 feet on Robeson Mountain. The rift is reported as vertical with courses of $\mathrm{N} .15^{\circ}, 26^{\circ}, 35^{\circ}$, and $60^{\circ} \mathrm{E}$., and the grain as uniformly horizontal. At one quarry the rift has to be followed. closely in winter, but the rock is reported as splitting with equal facility in any direction in summer. 
Flow structure appears with a dip of $50^{\circ} \mathrm{SW}$. There is an irregular banding at the old Drenan quarry caused by unequal distribution of biotite. The schist capping is exposed at another of the Drenan openings, and the 100-foot mass of schist at the back of the Webber quarry is either part of the same or a very large inclusion. The schist inclusions on Robeson Mountain, 25 and 8 feet long, have been referred to on page 100. A small light-greenish calcareous inclusion at the Ainsworth quarry proves to be chiefly crystalline calcite with quartz particles under 0.1 millimeter, together with apatite and secondary epidote and zoisite, and has veinlets of epidote, quartz, and calcite. This appears to have originally been a quartzose marble, and its interest lies in its evidence of the presence of calcareous rocks here prior to the granite intrusion.

There are biotitic segregations up to 2 feet in diameter. Small pegmatite dikes at the Chase quarries, near Buck Pond, strike about north, and a 4-inch quartz vein on the northwest side of Robeson Mountain strikes N. $35^{\circ}$ to $40^{\circ}$ E.

\section{FLETCHER QUARRY.}

The Fletcher quarry is on Robeson Mountain near its west-southwest end and on its southeast side, in Woodbury. (See fig. 8.) Operator, E. R. Fletcher, Hardwick, Vt.

The granite (specimens D, XXIX, 56, a, c), "Woodbury gray," is a biotite granite of light-gray shade (between "light Barre" and the granite of Hallowell, Me.) and of medium texture with feldspars up to 0.3 inch and mica to 0.1 inch. Its constituents, in descending order of abundance, are: Clear to translucent bluish potash feldspar (orthoclase, some of it minutely intergrown with plagioclase, also microcline), the larger particles with inclusions of biotite and sodalime feldspar; medium smoky quartz with hairlike crystals of rutile and cavities in two sets of rectangular sheets with rift and grain cracks parallel to them; milk-white soda-lime feldspar (oligoclasealbite) much kaolinized, somewhat micacized and epidotized, and with calcite; biotite (black mica) some of it chloritized; and a little muscovite or bleached biotite. Accessory: Pyrite, titanite, zircon, apatite, rutile. Secondary: Kaolin, a white mica, epidote, zoisite, calcite, limonito.

An estimate of the mineral percentages by the Rosiwal method yields these results with a mesh of 0.5 inch and a total linear length of. 46.5 inches:

Estimated mineral percentages in granite of Fletcher quarry, Woodbury.

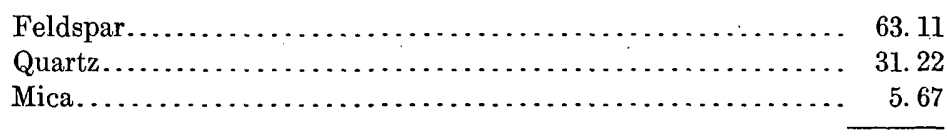


The average diameters of the particles by the same calculation are: Feldspars (adding 20 per cent to number for plagioclase), 0.103 inch; quartz, 0.1 inch; mica, 0.029 inch.

The stone effervesces very slightly with cold dilute muriatic acid. W. T. Schaller, chemist, of the United States Geological Survey, finds that it contains 0.16 per cent of $\mathrm{CaO}$ (lime) soluble in warm dilute (10 per cent) acetic acid, which indicates a content of 0.28 per cent of $\mathrm{CaCO}_{3}$ (lime carbonate, calcite), the presence of which mineral is also shown by the microscope.

This is a brilliant granite with marked mineral contrasts. The quartz and feldspar areas are rather large and well defined. The polish is poor owing to the large size of the micas. The polished face shows some pyrite.

The quarry, opened about 1887 , is estimated as measuring 300 feet in a northwest direction or across the ridge, by 300 along it, and from 20 to 40 feet in depth. It is practically the beginning of a cross section of the ridge and dome.

The complex sheet structure here has already been described (p. 17) and is shown in Plate IV, $B$. The primary sheets, 1 to 5 feet thick, are horizontal at the northwest and upper side of the quarry, but gradually bend over and dip $20^{\circ}$ to $30^{\circ} \mathrm{SE}$. at the lower southeast side. The secondary set, 5 to 9 feet thick, dips $5^{\circ}$ to $10^{\circ}$ about W. across the other. There are three sets of joints: (a), striking N. $30^{\circ}$ E., vertical, is spaced 6 to 30 feet and over; (b), striking N. $65^{\circ} \mathrm{E}$., dipping $75^{\circ} \mathrm{N} .25^{\circ} \mathrm{W}$, one only in southeast part; (c), striking N. $20^{\circ} \mathrm{W}$., vertical, is spaced 2 to 15 feet. There are no headings. Some of the joint faces are greenish probably from chlorite. The rift is reported as vertical with $\mathrm{N} .35^{\circ}$ E. course and the grain as horizontal. Flow structure consists of biotitic streaks of irregular course. Biotitic knots from 1 to 3 inches across are reported. There is a marked northeast-southwest compressive strain in the upper part of the quarry, raising the sheets and even forming new sheet partings. There is no rusty stain whatever on sheet surfaces.

The plant comprises, at the quarry two derricks (one of them of 40 tons) and a large rock drill; at the cutting shed at Hardwick a 10-ton and a 15-ton derrick, a hoisting engine, a 10-ton locomotive crane, a 40-horsepower engine, and three polishers.

Transportation is effected by siding from the Hardwick and Woodbury Railroad, which brings the stone 8 miles to the cutting shed, and to the St. Johnsbury and Lake Champlain Railroad. (See fig. 8.)

The product is used for monuments and buildings. Specimens: Base of the General Sherman monument, Washington, D. C.; Home4782-Bull. 404-09-7 
wood Cemetery entrance, Allegheny, Pa.; Crandall monument, Crandall Park, Glens Falls, N. Y. (this is a pentagonal shaft 36 feet by 4 feet 10 inches by 5 feet); base courses, approaches, and steps to post-offices at Atlantic City, N. J., and Jacksonville, Ill.

WOODBURY GRANITE COMPANY'S QUARRIES.

The Woodbury Granite Company's quarries are on . Robeson Mountain, roughly from 1,400 to 2,100 feet N. $80^{\circ} \mathrm{E}$. from the Fletcher quarry, in Woodbury. (See fig. 8.) Operator, Woodbury Granite Company, Hardwick, Vt.

The granite is of two sorts. Specimen D, XXIX, 57, b and c, "Woodbury gray," is a biotite granite of medium gray shade and medium texture with feldspar up to 0.3 inch and mica to 0.1 inch. Its constituents, in descending order of abundance, are: Clear to bluish translucent potash feldspar (microcline and orthoclase) somewhat kaolinized; light smoky quartz with hairlike crystals of rutile, and cavities in sheets with rift and grain cracks parallel to or coinciding with them; milk-white soda-lime feldspar (oligoclase) considerably kaolinized but not micacized or epidotized, in places intergrown with quartz in vermicular structure; biotite (black mica); and a little muscovite or bleached biotite. Accessory: Pyrite, apatite, zircon, rutile. Secondary: Kaolin and zoisite. Carbonate and epidote were not detected. There is no effervescence with cold dilute muriatic acid.

An estimate of the mineral percentages by the Rosiwal method with a mesh of 0.3 inch and a total linear length of 38.1 inches yielded these results:

Estimated mineral percentages in granite in Woodbury Granite Company's lower quarry.

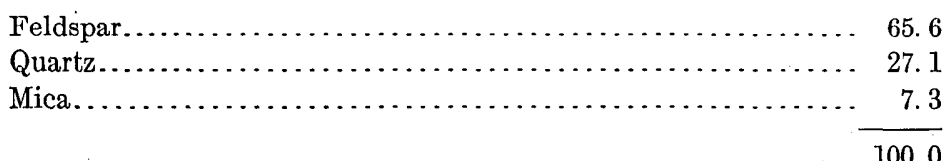

The average diameters of all the particles by the same calculation is 0.084 inch; that of the feldspar (adding 20 per cent to the number for the plagioclase as in calculation for average diameter), is 0.105 inch; quartz, $0.074 \mathrm{inch}$; and mica, 0.025 inch.

This stone to the eye is like that of the Fletcher quarry; except that its quartz particles are a little finer, less numerous, and less smoky. Its mineral contrasts are, therefore, weaker. The polish is poor, owing to abundant and rather large mica scales, but the contrasts on the polished face are strong. It shows a little pyrite.

The other sort (specimens D, XXIX, 57, a and d), "Woodbury Bashaw," is a biotite granite of medium-gray shade (about like that 
of "Concord granite" but more bluish and with more contrasts), and of fine inclining to medium texture with feldspars up to 0.2 inch and mica to 0.1 inch. Its constituents, in descending order of abundance, are: Clear to translucent bluish potash feldspar (microcline and orthoclase), light smoky quartz with cavities in two sets of rectangular sheets, with rift and grain cracks parallel to them, respectively. The rift cracks extend into the feldspars and are filled with fibrous muscovite; milk-white soda-lime feldspar (oligoclase) much micacized with epidote and calcite, also intergrown with quartz in vermicular structure; biotite (black mica), some of it chloritized; a little muscovite or bleached biotite. Accessory: Pyrite, zircon crystals, apatite. Secondary: A white mica, epidote, calcite, chlorite. The stone effervesces slightly with cold dilute muriatic acid.

This is a monumental granite. Its mineral contrasts are not as marked either in the rough or the polish as in the "Woodbury gray." This is due to the feldspars being less kaolinized and thus less white. Its texture is finer and it polishes better. The polished face shows a little pyrite.

Three compression tests of the "Woodbury gray" made for the firm at the United States Arsenal at Watertown, Mass. (test No. 13261), yielded these results:

Compressive strength of "Woodbury gray" granite.

\begin{tabular}{|c|c|}
\hline 0 & $\begin{array}{l}\text { Pounds per } \\
\text { square inch. }\end{array}$ \\
\hline First crack, 199,000 pounds; ultimate strength. & .. 22,460 \\
\hline First crack, 181,000 pounds; ultimate strength. & 19,850 \\
\hline First crack, 168,000 pounds; ultimate strength. & 20,110 \\
\hline
\end{tabular}

The quarries consist of four openings: The main and western one, made in 1880, beginning at the south foot of the ridge, extends about 500 feet along it and 400 feet northward up its side, with an average depth of 50 feet. The "upper quarry," above and north of the main one, is about 200 feet square, and its north side is at the top of the hill nearly 300 feet higher than the lower edge of the main quarry. The third opening, about 800 feet east of the main one, made in 1906, is about 125 by 70 feet and from 10 to 30 feet deep. This produces the finer monumental granite, "Woodbury Bashaw," described on page 98 . The fourth is a small opening made in 1907, about 200 feet northwest of the third.

The sheets at the top of upper quarry and of the ridge are horizontal. In the third opening they are from 2 to 13 feet thick, ill defined, and about horizontal. In the main quarry they range from 2 to 18 feet, exceptionally 23 feet and even 40 , curving over from the horizontal to dip $20^{\circ} \mathrm{S}$. They are intersected by a horizontal 
set. (See pp. 17, 97.) The joint courses (shown in fig. 23) are four: (A) dips $60^{\circ}$ to $65^{\circ} \mathrm{N}$., $35^{\circ} \mathrm{E}$. (some vertical, discontinuous), spaced 20 to 40 and 200 feet; (B), vertical or dipping $75^{\circ} \mathrm{W}$., discontinuous along the dip, in third opening spaced 10 to 30 feet, but in main quarry mostly headings, five in all, 3 to 30 feet wide and 30 to 50 feet apart;

(C) is vertical, discontinuous, and much more open than (A) or (B); (D) is spaced 2 and 10 to 40 feet. The rift is reported as vertical and the grain as horizontal, but not marked. The rift has to be followed closely in winter, but in summer the rock splits almost any way. There are two schist inclusions in the main quarry, 25 by 10 feet and 8 feet by (?), also some smaller ones. Rusty stain measures from 1 to 18 inches on sheet surfaces.

The plant at the quarries comprises a 75 -ton, a 50 -ton, three 40 -ton, a 30-ton, and two 20-ton derricks, seven hoisting engines, three Blondin carriers with two engines and cables $1,200,800$, and 700 feet

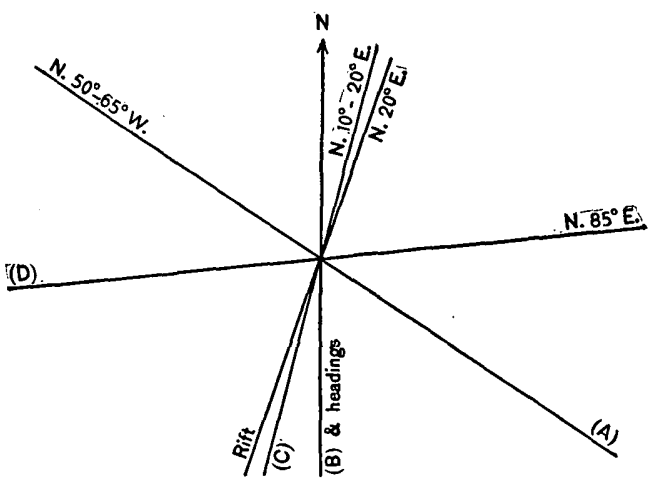

FIGURE 23.-Structure at Woodbury Granite Company's quarries, on Robeson Mountain.

long to carry waste to the dumps in the valley, an air compressor (capacity 1,160 cubic feet of air per minute), five large rock drills, twenty-four air plug drills, and eight hollow-steel drills ("bull machines") for blowing out powdered granite. The plant at the cutting sheds at Hardwick comprises three derricks; two overhead 20 and 40 ton cranes, an outdoor overhead traveling 30-ton crane operated on a trestle 575 feet long and of 75 -foot span to facilitate storage of finished stones and rapid loading of cars, two air compressors (capacity 1,000 and 500 cubic feet of air per minute), eleven air plug drills, 65 air hand tools, six surfacers, a polisher, four lathes for stones 35 by 4 feet, 13 feet by 2 feet 6 inches, 12 by 2 feet, and 13 feet by 1 foot, two polishing lathes for stones 25 by 5 and by 3 feet, two saws for stones 10 by 8 by 6 feet and 16 by 6 by 7 feet, two MacDonald combined planers and surfacers. The firm in 1908 was engaged in equipping its electric power station with a 4-foot tubular steel penstock to secure a higher head, and two motor generator sets of capacity of 250 kilowatts each. The power line was being extended 6 miles to the quarry plant, in order to run it by electricity also and do away with steam engines. 
Transportation is by siding from the Hardwick and Woodbury Railroad (see fig. 8), which brings the stone 8 miles to the cutting shed, and the St. Johnsbury and Lake Champlain Railroad.

The product is used both for buildings and monuments. Specimens of buildings: Pennsylvania capitol, Harrisburg; Cook County court-house, Chicago; base course and 36 interior polished columns of Kentucky capitol, Frankfort; post-office and custom-house, Providence, R. I.; Carnegie Library, Syracuse, N. Y.; Homeopathic Hospital, Pittsburg, Pa.; Bank of Ohio Valley, Wheeling, W. Va.; Hotel Pontchartrain, Detroit, Mich.; Mandell residence, Boston, Mass. Specimens of monuments: Soldiers and sailors' monument, Scranton, Pa.; soldiers' monument, Manchester, Vt.; memorial archway, Port Huron, Mich.; and the Flower memorial, Watertown, N. Y. The adaptability of the granite for carving is shown in Plate IV, $A$, representing a panel on the Cook County court-house.

\section{CARSON QUARRY.}

The Carson quarry is on the northeast foot of Robeson Mountain, in Woodbury. (Seefig. 8.) Operators, Carson Brothers, Woodbury, Vt.

The granite is a biotite granite similar to that of the main quarry of the Woodbury Granite Company, page 98.

The quarry was barely opened in 1907 . The sheets are thick.

Transportation is by cart, one-third of a mile to the Hardwick and Woodbury Railroad.

\section{AINSWORTH QUARRY.}

The Ainsworth quarry is on the northeast foot of Robeson Mountain, in Woodbury, about 1,000 feet northeast of the railroad. (See fig. 8.) Operators, Ainsworth \& Ainsworth, Woodbury, Vt.

The granite is a biotite granite similar to that of the main quarry of the Woodbury Granite Company, page 98.

The quarry consists of two openings: One 50 by 35 feet and 15 feet deep; the other, about 500 feet west of the first, is 50 by 20 and 10 feet deep.

The sheets are from 15 to 20 feet thick. There are very dark gray knots up to 2 feet by 1 foot, with half-inch porphyritic feldspars, much fine biotite, and not a little pyrite. A small inclusion of finegrained quartzose marble was noticed on page 96 .

The plant comprises a hand and a horse derrick.

The stone has to be carted 1,000 feet or more to rail. The quarry is not worked in haying time.

\section{MILLER QUARRY.}

The Miller quarry is about 500 feet west-southwest of the last. Operator, G. F. Miller, Woodbury, Vt.

This is a small opening of recent date. A flow structure dipping $50^{\circ} \mathrm{SW}$. was noticed. 
DRENAN QUARRIES.

The Drenan quarries are in Woodbury, on the rising land north of the east end of Robeson Mountain, and about 150 feet above the north spur of the Hardwick and Woodbury Railroad. (See fig. 8.) Operators, Drenan, Brown \& Raycraft, Woodbury, Vt.

The granite of the new opening now worked (specimen D, XXIX, 65 , a), "Woodbury fine dark gray," is a biotite granite of dark bluishgray shade and fine texture with feldspar up to 0.2 inch and mica to 0.1 inch, but with some large clear sparse feldspars formed about the other minerals. As many of these have their cleavage parallel, the rough rock face seen at a certain angle has a brilliant sheen. Its constituents, in descending order of abundance, are clear colorless to translucent potash feldspar (microcline and orthoclase) slightly kaolinized, with inclusions of biotite, quartz, and soda-lime feldspar; clear, colorless quartz with cavities in sheets; bluish milk-white sodalime feldspar (albite to oligoclase-albite) kaolinized and micacized, also with calcite; biotite (black mica); and a little muscovite or bleached biotite. Accessory: Pyrite, apatite, zircon. Secondary: Kaolin, a white mica, calcite, zoisite. The stone effervesces with cold dilute muriatic acid.

This is a monumental granite of the same shade as "dark Barre" but of finer texture. It is darker than any of the granites of Robeson Mountain.

The quarry consists of three openings, two of which are abandoned. The last, made in 1907, is 200 by 100 feet and shallow.

The structure at the new opening is insufficiently exposed. Rift is reported as vertical with N. $60^{\circ}$ E. course and the grain as horizontal. The area of this fine granite is said to measure about 200 feet square, with coarser granite around it. At one of the older openings, a few hundred feet south, a medium gray granite is banded with a less biotitic, very light gray granite (specimen D, XXIX, 65, b). This is even grained and fine textured, with feldspar up to 0.2 inch and mica to 0.05 inch. Its quartz is very pale smoky; its feldspar very light cream color. The second feldspar is oligoclase-albite, kaolinized and micacized and with some grains of epidote and zoisite. There are dark biotitic knots 12 by 6 inches. At the third opening, a few hundred feet west of that last described, the granite is capped on the west by schist 20 feet thick.

The plant consists of three hand derricks, an air compressor (capacity 125 cubic feet of air per minute) run by a gasoline engine. 
Within a few hundred feet west of the old Drenan openings there is a considerable ledge which has been prospected for building granite.

This is a biotite granite of very light, slightly buff or cream-tinted gray shade, and of medium texture with feldspars up to 0.3 inch and with sparse black mica to 0.15 inch. Its quartz is pale smoky. The mica is in strong contrast to the quartz and feldspar.

\section{WEBBER QUARRIES}

The Webber quarries are in Woodbury, still farther north of Robeson Mountain, on a mass which is continuous with that on the southeast side of Buck Pond. (See figure 8.) Operator, Webber Granite Company, Hardwick, Vt.

The granite of the main and older opening (specimen D, XXIX, 68 , a), "Woodbury gray," is a biotite granite of light bluish-gray shade and of medium inclining to fine texture, with feldspars up to 0.3 inch and mica to 0.15 inch. It is slightly more bluish and finer textured than the gray of the main quarry of the Woodbury Granite Company and lighter in shade than their "Bashaw," and a trifle darker than "light Barre." Its constituents, in descending order of abundance, are: Clear to bluish translucent potash feldspar (microcline and orthoclase), slightly kaolinized with inclusions of biotite, quartz, and soda-lime feldspar; light smoky quartz with hairlike crystals of rutile and cavities in sheets; milk-white soda-lime feldspar (oligoclase-albite) kaolinized and micacized and with calcite, with rims radially intergrown with quartz; biotite (black mica), some of it chloritized; a little muscovite or bleached biotite. Accessory: Magnetite, rutile. Secondary: Kaolin, a white mica, calcite, chlorite, epidote. There is scarcely any effervescence with cold dilute muriatic acid.

The stone of an opening made in 1907 (specimen D, XXIX, 67, a), "Woodbury fine dark gray," is a biotite granite of dark bluishgray shade and of fine texture with feldspar up to 0.2 inch and mica to 0.1 inch, and with sparse clear porphyritic feldspars up to 0.3 inch, with inclusions of quartz and mica. This granite, as to its constituents, is identical with that of the Drenan quarry (specimen 65 , a) described on page 102, and it has the same peculiar sheen. Its soda-lime feldspar is oligoclase-albite. It effervesces in cold dilute muriatic acid.

This is a monumental granite of dark bluish-gray color corresponding to "dark Barre" but of finer texture.

The main opening is about 150 feet in a $\mathrm{N} .65^{\circ} \mathrm{W}$. direction, by 75 feet across, and from 10 to 25 feet deep.

The sheets, 8 feet thick, are horizontal or dip northwest. There are four sets of joints: (a), striking $\mathrm{N} .60^{\circ}$ to $65^{\circ} \mathrm{W}$. and vertical, 
forms the northeast wall, is spaced 50 feet; (b), striking N. $25^{\circ}$ to $30^{\circ}$ W. and vertical, is discontinuous; (c), striking N. $60^{\circ} \mathrm{E}$. and vertical, forms the northeast and southwest walls; (d), striking N. $20^{\circ} \mathrm{E}$. and vertical, discontinuous, is spaced 25 feet and over. The rift is reported as vertical with $\mathrm{N} .15^{\circ} \mathrm{E}$. course and the grain as horizontal. There is a mass of mica slate on the east wall 100 feet long and 10 feet wide with a foliation striking N. $20^{\circ} \mathrm{E}$. and dipping $55^{\circ} \mathrm{E}$. It is veined by granite.

The plant comprises one hand and two horse derricks, an air compressor (capacity 110 cubic feet of air per minute), a large rock drill, and three air plug drills.

Transportation is by a siding from the Hardwick and Woodbury Railroad.

FRYATT' \& CARR PROSPECT.

Fryatt \& Carr, of Woodbury, in 1907 were quarrying bowlders and possibly surface sheets a little south of the Webber quarries near the railroad switch on the south side of the track.

BUCK POND QUARRIES AND GRANITES.

Between the southwest end of Buck Pond and the new Webber quarry, roughly 500 feet north of the latter, is an abandoned quarry of biotite granite of dark bluish-gray shade and fine texture (specimen D, XXIX, 69, a) identical with specimens 65 , a, and 67 , a, of the new Drenan and Webber openings described on pages 102, 103. (See fig. 8.) The sheets, 5 to 8 feet thick, dip gently south. There is an east-west working face 100 feet long and 35 feet high without headings. Two sets of joints strike east and north, respectively.

On the southeast side of the pond, possibly 1,000 feet roughly northwest of the above quarry and on the west side of a granite ridge, is another abandoned opening. The rock (specimen D, XXIX, 70 , a) is a biotite granite of light bluish-gray shade but of medium texture, with feldspar to 0.3 inch. It is more bluish than any of the granites of Robeson Mountain. Its texture is slightly coarser than that of the old opening of the Webber quarry (specimen 68, a), and also than the granites on the other side of the pond.

CHASE QUARRIES.

The Chase quarries are on the first high bluff northwest of Robeson Mountain, over 500 feet northwest of Buck Pond and 200 feet above it. (See fig. 8.) They have been idle for several years. The stone is a biotite granite of light bluish-gray shade and medium inclining to fine texture, identical with specimen 68 , a, of the Webber main quarry described on page 103 . There is a working face on the west 150 feet long and 40 feet high. The sheets, up to 8 feet thick, dip 
gently northeast. Pegmatite dikes, 2 inches thick, cross the granite beyond the face with $30^{\circ} \mathrm{W}$. dip.

Near the southwest end of the pond, but on the west side of its outlet and on the ridge, are two small recent openings. One was operated by Elmer Leach. The granite is of dark bluish-gray shade and medium inclining to fine texture. It resembles that of the Webber and Chase quarries, but is darker. The sheets, from 4 to 5 feet thick, are about horizontal.

NICHOLS LEDGE CARTER QUARRY.

The Nichols Ledge Carter quarry is at the northeast foot of Nichols Ledge in the east corner of the town of Woodbury. It is near the A. Dutton house, now occupied by A. D. Kimball. (See fig. 8.) Operator, J. H. McLeod, Hardwick, Vt. It was not worked in 1907.

The granite (specimen D, XXIX, 61, b) is a biotite granite of light inclining to medium bluish-gray shade and of fine to very fine texture, with feldspars up to 0.2 inch and mica to 0.1 inch, also with larger porphyritic clear feldspars formed about the other minerals. It is finer textured than the stone of the new Drenan and Webber openings (pp. 102, 103) and of lighter shade. Its constituents, in descending order of abundance, are clear, colorless potash feldspar (orthoclase and microcline); clear quartz with apatite needles and some cavities in sheets; bluish to milk-white soda-lime feldspar (oligoclase to oligoclase-andesine), but little kaolinized; olive-colored biotite (black mica) and a little muscovite or bleached biotite. Some of the feldspar is minutely intergrown with quartz. Accessory: Titanite, apatite. Secondary: Kaolin, epidote, calcite. It does not effervesce with cold dilute muriatic acid.

The sheets are up to 2 feet thick. There are some biotite knots. A similar granite is reported as once quarried by L. C. Fisher on the north side of Nichols Ledge.

\section{WINDHAM COUNTY.}

DUMMERSTON.

GENERAL STATEMENT.

The Dummerston granite area lies 5 and 6 miles north-northwest of Brattleboro and is shown on the state geologic map of 1861 as surrounded by "calciferous mica schist," with a belt of "clay slate" east of it along the Connecticut. The quarries and prospects are in the southwest part of the town on the sides of Black Mountain, and also half a mile south-southwest of it. Black Mountain, as shown on the United States Geological Survey reconnaissance topographic map (Brattleboro sheet), is on the east side of West River, 4 miles west of Connecticut River. This is a roundish granite mass, probably of 
dome structure, a square mile in area, and from 900 to 950 feet above West River, and 1,269 feet above sea level. The sheets on its southwest side dip $30^{\circ}$ to $40^{\circ}$ about west, and in its northwest part, about 350 feet above the river, $30^{\circ} \mathrm{N} .30^{\circ} \mathrm{W}$. As shown in Pl. III, $B$, a mass of sheets, about 35 feet thick at the foot of the mountain, does not appear to be normally related either in the thickness of its sheets or their attitude to the sheets above it. These thin sheets may either be of more recent origin than the others, or may be separated from them by a fault. The effect of compressive strain upon sheets in part of this quarry has been referred to on page 25 and illustrated in Plate VIII, $B$, of Bulletin 354 .

The granites of Dummerston are quartz monzonites of very light gray and light bluish-gray shade and of even-grained medium or medium inclining to fine texture.

BLACK MOUNTAIN QUARRY.

The Black Mountain quarry is at the southwest foot of Black Mountain, three-fourths mile south-southeast of the village of West Dummerston, in Dummerston, and 5 miles north-northwest of Brattleboro. Operator, George E. Lyons Company, West Dummerston, Vt.; main office, Monson, Mass.

The granite, of two sorts, chiefly "West Dummerston white" (specimen D, XXIX, 90, b), is a quartz monzonite of very light gray shade, speckled with bronze-colored mica (muscovite and biotite), and of even-grained medium 'texture, with feldspars up to 0.3 inch and mica to 0.1 inch. Its constituents, in descending order of abundance, are clear to pale smoky quartz, showing effect of strain, with hairlike crystals of rutile and a few fluidal cavities in sheets; milk-white soda-lime feldspar (oligoclase to oligoclase-albite), some of it with flexed twinning planes, kaolinized and micacized; clear potash feldspar (microcline and orthoclase); muscovite and less biotite apparently intergrown and bent or twisted with fibrous muscovite stringers extending out from them into and between the other particles. Accessory: Apatite, rutile. Secondary: Kaolin, white micas, epidote, zoisite, calcite. There are crush borders about the quartz and feldspar particles.

This stone effervesces slightly with cold dilute muriatic acid. W. T. Schaller, chemist, of the United States Geological Survey, finds that it contains 0.07 of $\mathrm{CaO}$ (lime) soluble in warm dilute (10 per cent) acetic acid, which indicates a content of 0.125 per cent of $\mathrm{CaCO}_{3}$ (lime carbonate, calcite), the presence of which mineral is also shown by the microscope.

A compression test, made on a 4 -inch cube at the United States Arsenal at Watertown, Mass., in 1905, showed the first crack at 
308,000 pounds, and an ultimate compressive strength of 27,810 pounds per square inch.

This is a building granite of medium grain and very light shade, between that of North Jay, Me., and that of Bethel, Vt., in whiteness.

The other granite (specimen D, XXIX, 90, a), "dark blue," is a quartz monzonite of light inclining to medium bluish-gray color, and of even-grained fine inclining to medium texture with feldspars up to 0.2 inch and mica to 0.1 inch. Its constituents are identical with those of the "white" specimen 90 , b, but its oligoclase-albite is bluish and less altered, and its mica nearly all muscovite. It shows less calcite in thin section and does not effervesce with cold dilute muriatic acid.

This is a monumental granite of light bluish-gray tint and without mineral contrasts.

The quarry, opened about 1877 , is estimated as measuring about 1,200 feet in a N. $20^{\circ} \mathrm{W}$. direction along the base of the mountain, by 200 feet across and from 15 to 50 feet deep.

The sheets for a thickness of 25 to 35 feet above the road level, and for a length of 100 feet, are from 6 inches to 2 feet thick, and are horizontal or slightly inclined west. (See Pl. III, B.) - Below the road level they measure up to 14 feet in thickness and dip $20^{\circ} \mathrm{W}$., although horizontal for short spaces. Above this thin-sheeted mass they dip $30^{\circ}$ to $40^{\circ} \mathrm{W}$., and are considerably thicker. At the north end of the quarry compressive strain forms new thin sheets and parts them. (See p. 17.) There are two sets of joints: (a), striking N. $15^{\circ}$ E., vertical, is spaced 7 to 30 feet; of (b), striking N. $20^{\circ}$ W., dipping $80^{\circ} \mathrm{N} .70^{\circ} \mathrm{E}$., there is only one, at the south end. Flow structure strikes N. $22^{\circ}$ E. and dips $80^{\circ}$ N. $80^{\circ}$ W. The rift is reported as vertical with $\mathrm{N} .15^{\circ} \mathrm{E}$. course and parallel to the mica plates, and the grain as horizonital. Both are good. Pegmatite dikes from 0.25 to 3 inches thick, with large light bluish-gray unstriated feldspars, strike N. $10^{\circ}$ E., etc. The light bluish granite occupies 350 feet of the north end of the quarry, the rest of it being "white." Knots are rare and up to 6 inches across. Rusty stain, up to 3 inches wide on the upper sheets, is generally. absent from the lower ones.

The plant comprises thirteen derricks, one of them of 20 tons, five hoisting engines, an air compressor, four large rock drills, a channel bar drill, and four air plug drills.

Transportation is by two sidings from the Vermont Central Railway. Stones for finishing are shipped to the firm's cutting plant, at Monson, Mass. 
The product is used for buildings, monuments, and street work. Specimens: Post-office at Troy, N. Y.; Diamond Bank, Pittsburg, Pa.; McFadden Building, Chicago, Ill.; Royal Baking Powder building and Plaza Hotel, New York.

CLARK QUARRIES.

The Clark quarries are east of West Dummerston village, on the northwest side of Black Mountain. Operator, James Clark, West Dummerston, $\mathrm{Vt}$.

The granite (specimen D, XXIX, 91, a) from the lower quarry, is a quartz monzonite of very light gray shade, with conspicuous black mica, and of even-grained medium inclining to fine texture, with feldspars up to 0.25 and 0.3 inch and mica to 0.15 inch. Its constituents, in descending order of abundance, are: Light smoky quartz showing effect of strain, and with some cavities in sheets; milk-white sodalime feldspar (oligoclase-albite), kaolinized, micacized, and with calcite, also intergrown with quartz in vermicular structure; clear, colorless potash feldspar (microcline and othoclase), with inclusions of the other feldspar and mica; biotite (black mica); muscovite or bleached biotite.

This differs from the "white" of the Black Mountain quarry in that the biotite is more prominent and the fibrous muscovite is absent.

The stone from the upper quarry appears to be exactly like the "white" of the Black Mountain quarry, page 106.

The lower opening is about 150 feet above the river bank and the upper about 330 feet. Both are small.

The sheets of the upper opening are from 6 inches to 2 feet 6 inches thick; those of the lower 10 to 12 feet. They strike N. $60^{\circ} \mathrm{E}$. and $\operatorname{dip} 30^{\circ} \mathrm{N} .30^{\circ} \mathrm{W}$.

There is no plant. The product, which is used for paving and curbing, is carted $1 \frac{1}{4}$ to $1 \frac{1}{2}$ miles to the railroad on the west bank of West River.

\section{BAILEY PROSPECTS.}

The Bailey prospects are on the west side of West River about onehalf mile south-southwest of the Black Mountain quarry, in Dummerston. Owner, David J. Bailey, R. F. D., Brattleboro, Vt.

The granite from an opening about 200 feet above the road to Brattleboro is a quartz monzonite of light-gray shade and medium inclining to fine even-grained texture, with feldspars up to 0.25 inch and mica mostly under 0.05 inch, and more thickly disseminated than in the "white" of the Black Mountain quarry. Its constituents are the same as in that stone, but the quartz is more smoky, the mica mostly biotite. The fibrous muscovite and crush borders are lacking. 
This stone is of slightly finer texture and, owing to the smokiness of its quartz and the distribution and amount of its biotite, of slightly darker shade than the "white." It is lighter than "light Barre."

The opening represented by this specimen is 200 by 15 feet, with a working face of 10 feet.

The sheets, up to 8 feet thick, dip $20^{\circ}$ to $25^{\circ}$ N. $35^{\circ} \mathrm{W}$. A granite ledge a little north-northwest of this is crossed by a dike of fine granite, 30 feet wide, with a N. $10^{\circ} \mathrm{W}$. course and dip of $50^{\circ} \mathrm{W}$. It is of medium bluish-gray shade and of very fine even-grained texture, with feldspar and mica up to 0.05 inch. In thin section its particles range from 0.074 to 1.1 millimeters in diameter. It is a quartz monzonite of similar composition to that of West Dummerston. Its mica is chiefly biotite. Feldspar and quartz are intergrown and have crush borders. The soda-lime feldspar is bluish gray and scarcely altered.

This fine granite, although probably harder than ordinary granites, may be found of economic value.

\section{WINDSOR COUNTY.}

The quarries of Windsor County are in the towns of Bethel, Rochester, and Windsor.

\section{BETHEL.}

TOPOGRAPHY AND GENERAI GEOLOGY.

The state map of 1861 represented a small granite area in the east corner of the town of Bethel, surrounded by "calciferous mica schist," with a north-south belt of "clay slate" a little west of it. This granite is on Christian Hill, an elongated mass rising about 350 feet above the adjacent hollows, about 2 miles north of Bethel village and east of White River. Its general position is shown on the map (fig. 24).

The granite exposure is reported as at least one-half mile long from north to south. Its width at the quarries is about 550 feet, with a border of finer less whitish granite on either side about 40 feet wide. The entire width between the schist on the east and west is not far from 625 feet, but there is said to be another narrower belt of granite several hundred feet east of the main one protruding through the schist. The mica schist immediately west of the granite strikes N. $10^{\circ} \mathrm{W}$. and dips $57^{\circ} \mathrm{E}$; ; that east of the granite (a garnetiferous mica slate), with 12 -inch calcareous beds, strikes north to N. $5^{\circ} \mathrm{E}$. and is vertical. The mica schist, in places chloritic, north of and near Bethel, strikes N. $10^{\circ}$ to $15^{\circ} \mathrm{W}$. and is vertical. While the main granite mass from its lateral zones of finer granite would appear to be a truncated arch or dome, its sheet structure all dips east from $15^{\circ}$ to $45^{\circ}$ on the east and $30^{\circ}$ on the west. The vertical north- 
south flow structure with its aligned discoid nodules of muscovite has been described on page 25 , and the details of the contact of granite and schist given on page 20, and shown in figures 3 and 4 . Neither of the quarries has as yet removed all the thin surface sheets, although they have furnished material for several very large buildings.

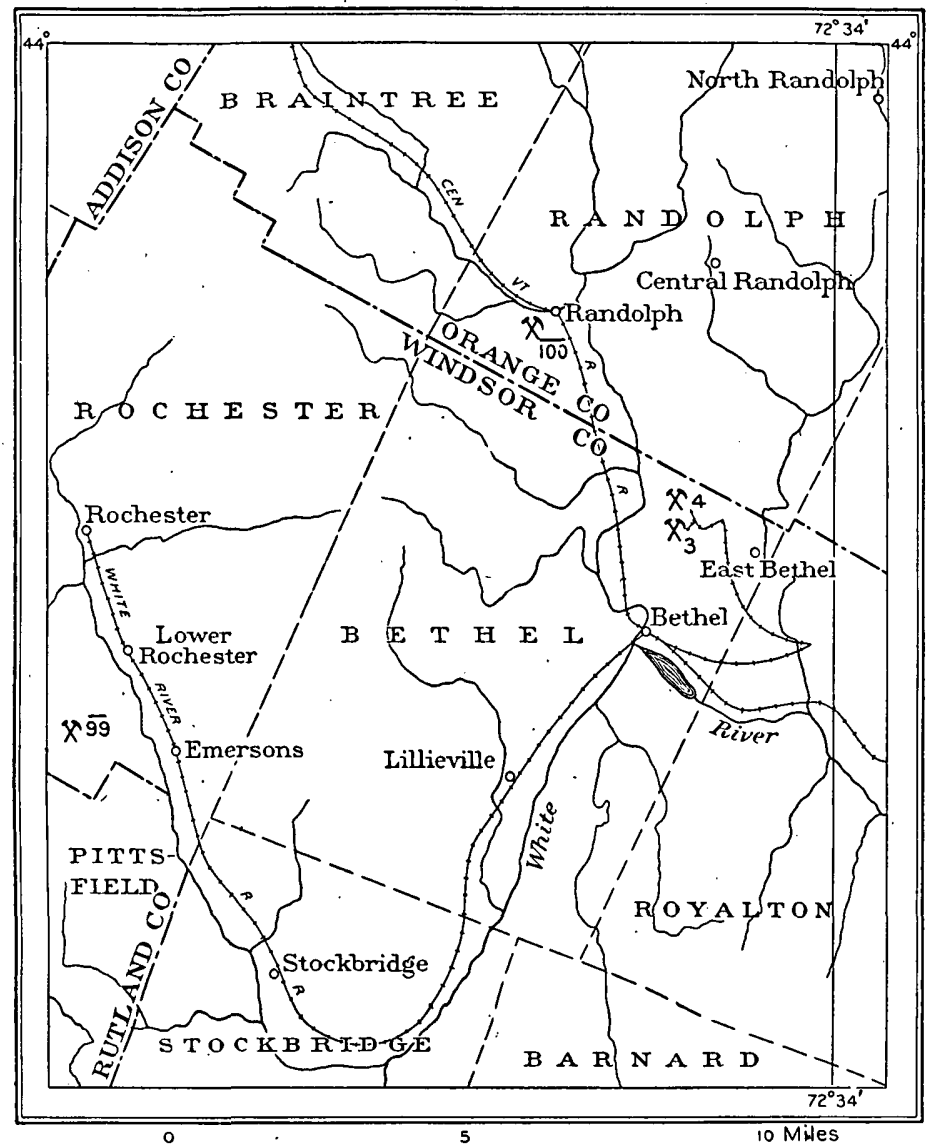

Figure 24.-Map of Bethel, Randolph, and Rochester, from Beers's Atlas. No. 3, Woodbury Granite Company's quarry; No. 4, Ellis quarry; No. 99, Liberty Hill quarry; No. 100, Beedle's prospect.

\section{"BETHEL GRANITE."}

The granite known under the commercial name "Bethel white granite," which has been copyrighted, and the granite consequently called by another firm "Hardwick white granite," from the location of its main office, are one and the same. The two quarries, but a few feet apart, are excavations in granite of one mass of contemporaneous origin and of identical composition and texture. The following description is based on specimens, rough and polished, and thin sections from both quarries. 
The granite of Bethel (specimens D, XXIX, 3, n, p, and 4, a, b), "Bethel white" or "Hardwick white," is a quartz monzonite of slightly bluish milk-white color, with grayish spots up to 0.3 inch, and of coarse inclining to medium texture, with feldspars up to 0.4 and 0.5 inch and mica to 0.3 inch. Its constituents, in descending order of abundance, are: Clear, colorless, rarely bluish quartz, with hairlike crystals of rutile, and with fluidal and other cavities in sheets, with rift cracks parallel thereto; bluish milk-white soda-lime feldspar (oligoclase) slightly kaolinized and micacized; clear potash feldspar (orthoclase, slightly kaolinized, with very little microcline); muscovite (white mica); and very little biotite (black mica). The accessory minerals are apatite, titanite, zircon, and rutile. No magnetite or pyrite was detected. The secondary minerals are kaolin, a white mica, epidote, zoisite in some abundance, and very little calcite.

The stone does not effervesce with cold dilute muriatic acid. W. T. Schaller, chemist, of the United States Geological Survey, finds that it contains 0.07 per cent of $\mathrm{CaO}$ (lime) soluble in dilute (10 per cent) acetic acid, which indicates a content of 0.125 per cent of $\mathrm{CaCO}$ (lime carbonate), which is very slight.

A chemical analysis made for the E. B. Fllis Granite Company by Charles F. McKenna, of New York, in 1903, is given here for reference.

Analysis of "Bethel granite," by Charles F. McKenna.

$\mathrm{SiO}_{2}$ (sllica)

77. 52

$\mathrm{Al}_{2} \mathrm{O}_{3}$ (alumina) 16. 78

$\mathrm{FeO}$ (iron oxide)

$\mathrm{MgO}$ (magnesia)

$\mathrm{CaO}$ (lime).

2. 56

$\mathrm{Na}_{2} \mathrm{O}$ (soda)

1. 21

$\mathrm{K}_{2} \mathrm{O}$ (potash)

Loss on isnition.

100. 18

Three cumpression tests (No. 13261) made at the United States Arsenal at Watertown, Mass., yielded these results (direction of rift in blocks not stated):

Compressive strength of white granite of Bethel.

First $\iota$ rack, 287,000 pounds; ultimate strength . . . . . . . . . . . . 33,120

First crack, 301,000 pounds; ultimate strength............. 34, 350

First crack, 272,000 pounds; ultimate strength............ 31, 990

Average......................................... 33, 153

The stone is regarded as relatively hard by workmen. Its grade of whiteness is shown by these comparisons: The "white" of North 
Jay, Me., is, technically, very light gray. The "white" of West Dummerston is a trifle lighter, that of Randolph (p. - ) lighter yet, and that of Bethel still lighter, strictly white mottled with gray. Its white is more blue than ordinary Vermont white marble, but is closely allied to its blue variety, but not its bluish gray. Owing probably to the abundance of its soda-lime feldspar, its hammered face is considerably whiter than its rough face and the hammering also diminishes the prominence of the gray micaceous spots. It takes a high polish, but the effect is to make the mica spots more conspicuous than they are even on the rough face. The polished specimens handled by the writer do not show any pyrite or magnetite. Plate V, $A$, representing a carved eagle, shows how the whiteness of the stone has overcome the effect of the coarseness of its texture. Although this granite is remarkably free from iron, its recent use in large edifices shows that extreme care should be exercised in handling it to prevent its absorbing rusty water or other discoloring liquids.

Leonard P. Kinnicutt, of the Worcester Polytechnic Institute, in December, 1908, made the following determinations of absorption in Bethel and other granites, by W. F. Hillebrand's method, for Norcross Brothers Company, of Worcester, Mass.

Water absorbed by 100 pounds of various granites.

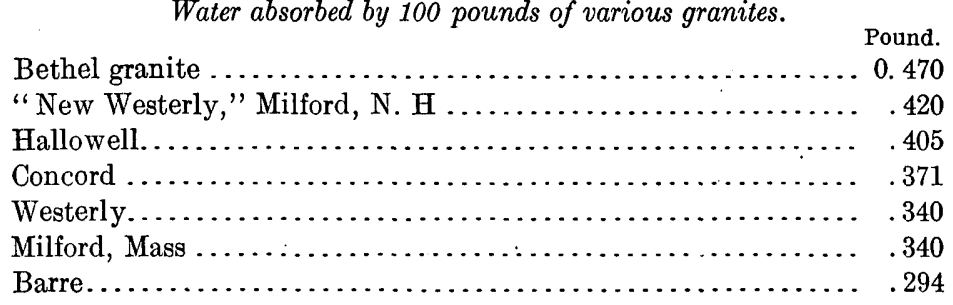

ELLIS QUARRY.

The Ellis quarry is on the east side of Christian Hill, about 2 miles north of Bethel village in Bethel township. (See fig. 24.) Operator, E. B. Ellis Grånite Company, Northfield, Vt.

The granite has been described above.

The quarry, permanently opened in 1902 , but in a small way many years earlier and abandoned, is estimated as being about 1,000 feet long north-south, and for the southern three-fifths of its length 150 feet wide, but for the remainder 400 feet wide. Its depth is from 5 to 40 feet, averaging about 15 feet. Its western edge is about 80 feet higher than its eastern.

The sheets, from 6 inches to 12 feet thick, but mostly 1 to 2 feet, strike N. $10^{\circ} \mathrm{W}$. and on the west side of the north end dip $30^{\circ} \mathrm{E}$., but on the east side $15^{\circ} \mathrm{E}$. For some not apparent reason the sheets thicken more rapidly at the east side and south end than in any other part of this or the adjoining quarry. Joint, grain, and.flow courses 
U. S. GEOLOGICAL SURVEY

BULLETIN 404 PLATE V

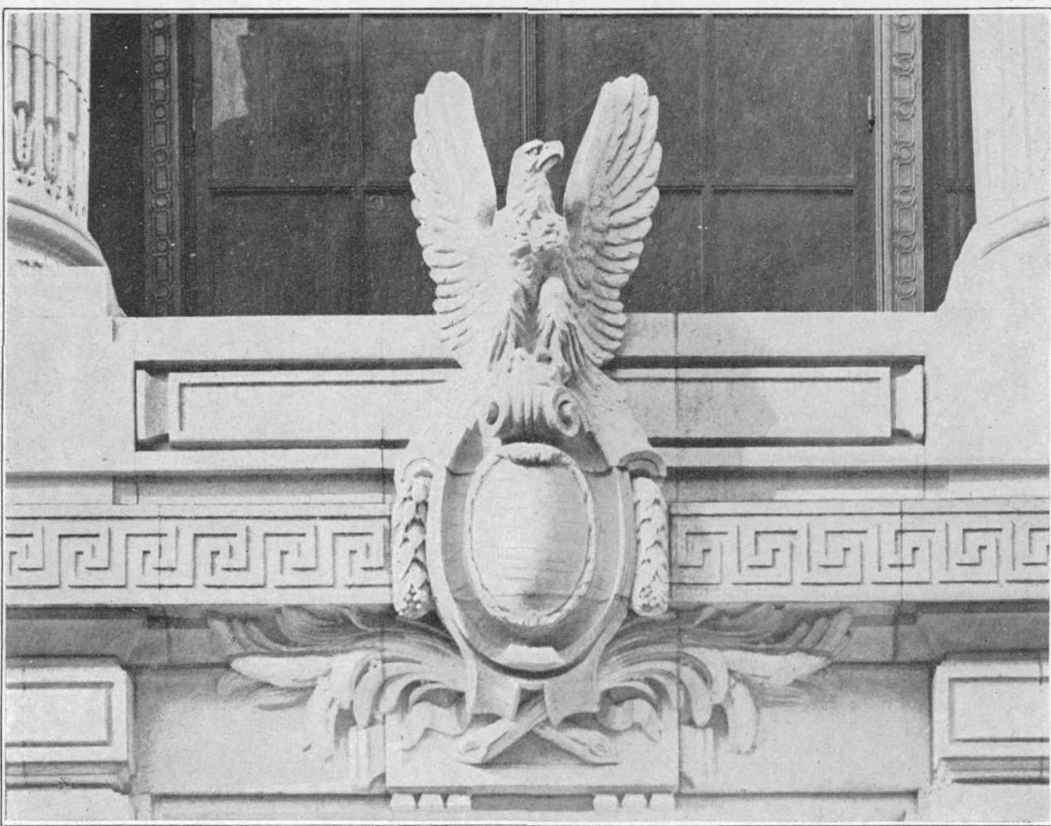

A. CARVED EAGLE OF COARSE WHITE QUARTZ MONZONITE FROM BETHEL OVER ENTRANCE TO AMERICAN BANK NOTE COMPANY'S BUILDING, NEW YORK.

Spread of wings, 32 inches; height from base of medallion to top of head, 7 feet 8 inches; depth of cary ing, 18 inches. The whiteness of the cut rock has counteracted the effect of its coarseness.

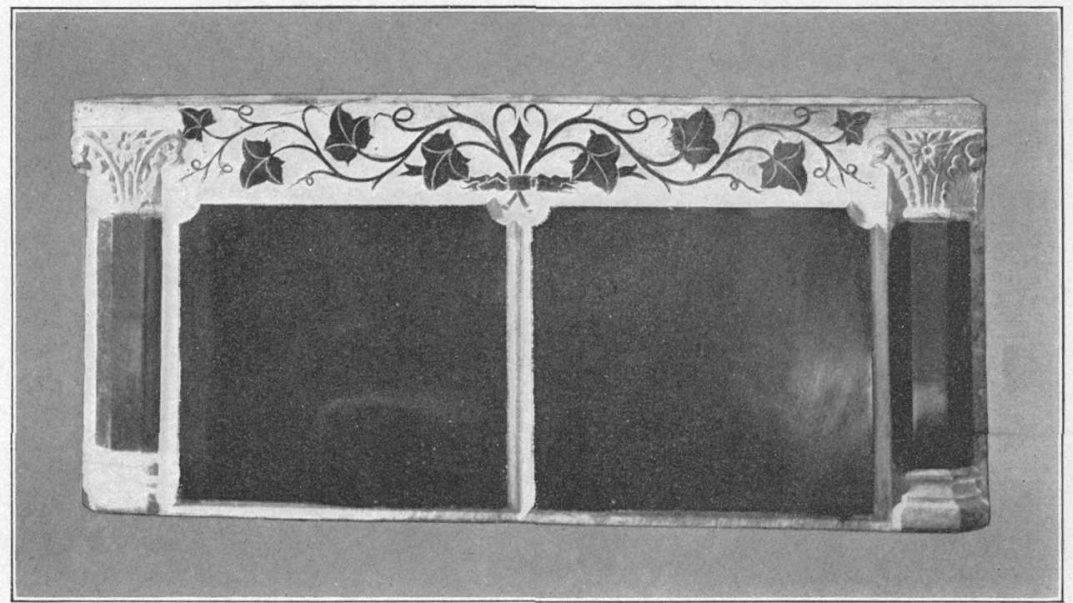

B. MONUMENT OF MOUNT ASCUTNEY DARK-GREEN HORNBLENDE-AUGITE GRANITE (SYENITE).

Showing contrast between polished (black) and hammered (white) surfaces. Size about 5 feet 8 inches by 2 feet 6 inches. 
are shown in figure 25. Joint set (A) is vertical, forms a heading at north end, recurs at two intervals of 80 feet; (B) is diagonal to the quarry and vertical, one only, about the middle of the side, but discontinuous. Compressive strain affects east-west channels more than north-south ones. Flow structure marked at the east side and south end, consists of micaceous (muscovite) streaks, up to 0.5 inch wide, and sheets of discoid nodules of muscovite, also of a branching mass, 12 inches thick, largely mica, and is vertical with north course. (For details see p. 25 and Pl. II, A.) The rift is reported as horizontal and the grain as vertical, with $\mathrm{N} .17^{\circ} \mathrm{E}$. course thus intersecting the flow structure at an acute angle. A few pegmatite dikes, up to 5 inches thick, have an east-west course. A quartz vein up to 1.5 inches wide strikes N. $80^{\circ} \mathrm{W}$. and dips $65^{\circ} \mathrm{S} .70^{\circ} \mathrm{W}$. Some minute muscovite and quartz veins strike N. $30^{\circ}$ to $35^{\circ} \mathrm{W}$. and dip $60^{\circ} \mathrm{S}$. $58^{\circ} \mathrm{W}$. There is one light-gray knot, 10 by 8 by 2 inches; also an inclusion, 21 by 12 by 5 inches, of fine-grained syenite gneiss consisting of orthoclase, biotite, epidote, and a little oligoclase with titanite and leucoxene, but with little or no quartz. There is no rusty stain on sheet surfaces. The relations of the coarse white granite to the fine, light-buff

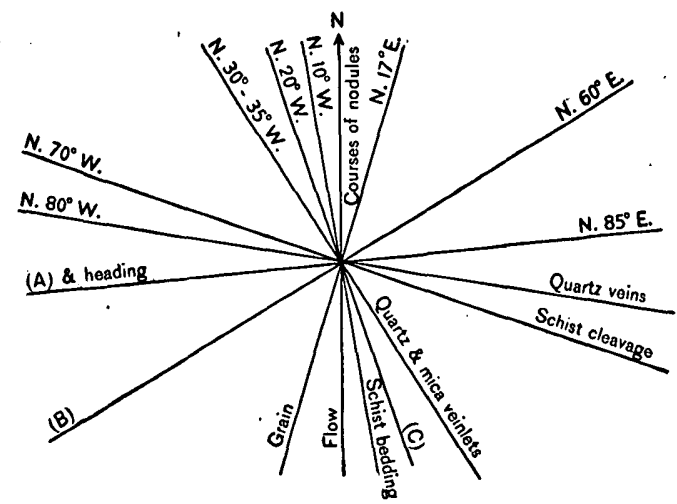

Figure 25.-Structure at Ellis and Woodbury granite com. panies' quarries, Bethel.

gray, and the contact of the latter with the schist have been described on page 20 and shown in figures 3 and 4 .

The plant at the quarry comprises ten derricks of 15 to 30 tons capacity, nine hoisting engines, an air compressor (capacity 750 cubic feet of air per minute), eleven large air rock drills, twenty-eight air plug drills, and four steam pumps.

The cutting plant at Northfield, Vt., comprises a 25 -ton derrick and engine, a 50-ton derrick and electric motor, two 20-ton and one 10-ton overhead crane, three air compressors (capacity, two of 800 and one of 300 cubic feet of air per minute), six air plug drills, one hundred and fifty air hand tools, eleven surfacers, two lathes for stones 25 by 3 by 2 feet; one Dietrich Harvey Company turning and fluting machine for columns 40 by 7 feet. The cutting plant is run by five electric engines, two of 100 , two of 75 , one of 35 , and one of 15 horsepower. Electricity is brought 14 miles from Mad River. 
Transportation is effected by siding, as shown in figure 24. Blocks destined for cutting are brought 5 miles to Bethel and thence 28 miles to the cutting shed at Northfield.

The product is used for buildings, monuments, and statuary. Specimens are the Union Station, with six monolithic statues 17 feet high, also with four eagles 8 feet high with spreading wings nearly 12 feet from tip to tip; and the first and second stories of the National Museum, Washington, D. C.; all the superstructure above water table in the State Library and Supreme Court Building, Hartford, Conn.; Hopper Monument, Woodlawn Cemetery, New York; Miller mausoleum, Poughkeepsie, N. Y.; Congdon residence, Duluth, Minn.

\section{- WOODBURY COMPANY'S QUARRY.}

The Woodbury Company's quarry is 50 feet north of the Ellis quarry, on the east side and top of Christian Hill, about 2 miles north of Bethel village, in Bethel township. (See fig. 24.) Operator, Woodbury Granite Company, Hardwick, Vt.

The granite has been described on page 111 .

The quarry, opened in 1902, is estimated as measuring about 500 feet north-south by 200 feet across and from 5 to 30 feet in depth.

The sheets, from 6 inches to 8 feet thick, are normal, dipping about $15^{\circ} \mathrm{E}$. At a recent small opening, about 300 feet north of the main one and on the east side of the highest part of the hill, the sheets dip $45^{\circ} \mathrm{E}$. There are two sets of joints (courses in fig. 25): (a), vertical, forms a 10-foot heading on the south wall between this and the Ellis quarry; (C), also vertical, is discontinuous and spaced 10 to 40 feet. An east-west compressive strain is reported by the foreman. The rift is reported as dipping less than $15^{\circ} \mathrm{E}$., and the grain as vertical, with nearly east-west course. Very few of the discoid micaceous nodules referred to (p. 113) occur. About 40 feet of fine buff-gray granite with schist farther east correspond to the same rocks on the west side of Ellis quarry. There is no rusty stain on sheet surfaces except near the heading.

The plant at the quarry comprises five derricks (one with 90-foot mast, the rest with 50 to 70 foot masts), a Blondin carrier, two air compressors (capacity 556 and 450 cubic feet of air per minute), four large rock air drills, 12 air plug drills, and two steam pumps.

The cutting plant at the firm's shed one-half mile south of Bethel village comprises one derrick, a 30-ton, a 20 -ton and a 10-ton overhead electric crane, two air compressors (capacity 1,200 and 260 cubic feet of air per minute), four air plug drills, 52 air hand tools, three surfacers, a polisher, and a 300-horsepower dynamo. Electricity is brought 5 miles from White River for this plant and sent 4 miles farther to the quarry. 
Transportation is by cart, 4 miles to the cutting shed near Bethel, which is on a siding.

The product is used for buildings. Examples are the new capitol of Wisconsin at Madison; American Bank Note Building, New York (Pl. V, $A$, represents a carving of this granite over the entrance to this building); Importers and Traders' National Bank, New York; Harry Payne Whitney residence, New York; Mary Ann Brown Memorial Library, Providence R. I.; grammar and high school buildings, Hartford, Conn.; entrance to Majestic Building, Detroit, Mich.

ROCHESTER.

LIBERTY HILL QUARRY.

The Liberty Hill quarry is 3 miles south of Rochester village (the west terminal of the White River Valley Railroad) and on the Rochester-Pittsfield town line. The outcrop extends into the town of Pittsfield, in Rutland County. (See fig. 24.) Operator, Liberty Hill Granite Corporation, Rochester, Vt.

The granite (specimens D, XXIX, 99, a, b), "coarse white granite," is a quartz monzonite of slightly greenish-white color with conspicuous brilliant muscovite spots up to 0.5 inch across and of coarse texture, with feldspars up to 0.5 inch. These mica spots being collections of mica scales, have a peculiar sheen. As they are not over 0.04 inch thick and lie with their flat sides roughly parallel, the rock has a somewhat gneissoid texture. Its constituents, in descending order of abundance, are: Milk-white to slightly greenish soda-lime feldspar (albite to oligoclase-albite), somewhat kaolinized and with thickly disseminated white mica scales to 0.15 millimeter long and not a few plates of calcite; clear colorless to pale bluish quartz rarely with hairlike crystals of rutile, and with fluidal and other cavities in two rectangular sets of sheets, one set with many more cavities than the other; orthoclase may be present in small amount, but was not detected. There is no microcline; muscovite (white mica) in large flakes and aggregates.

An estimate of the mineral percentages by the Rosiwal method yields these results with a mesh of 0.5 inch, total linear length of 35.5 inches, and on face at right angles to gneissoid structure:

Estimated mineral percentages in white granite of Rochester.

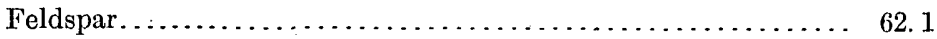

Quartz....................................... 29.6

Muscovite .................................. 8.3

100.0

The average diameter of all the particles obtained from the same measurements proves to be 0.34 inch; that of feldspar, 0.194 ; quartz, 0.106 ; and mica, 0.538 inch. 
The stone effervesces with cold dilute muriatic acid. W. T. Schaller, chemist of the United States Geological Survey, finds that it contains 1.38 per cent of $\mathrm{CaO}$ (lime) soluble in warm dilute (10 per cent) acetic acid, which indicates a content of 2.46 per cent of $\mathrm{CaCO}_{3}$ (lime carbonate, calcite), the presence of which mineral is also shown in thin section.

This is a building granite of very light pale greenish-gray color, with striking contrasts produced by large mica spots, the brilliancy of which on the fresh rift face is almost metallic. Whether its somewhat gneissoid texture and its content of nearly $2 \frac{1}{2}$ per cent of lime carbonate are serious obstacles to its use for building can only be determined by compression tests and by continued exposure to the weather.

The quarry, opened after the completion of the author's manuscript, was not visited.

In 1909 the corporation was filling a contract for the base course for the new gymnasium for Dartmouth College at Hanover, N. H.

Although the outcrop is 3 miles from Rochester station, its distance from the nearest point on the railroad is only about a mile and a siding is reported as having been constructed.

\section{WINDSOR.}

TOPOGRAPHY AND GENERAL GEOLOGY.

The state map of 1861 shows a granite area in the southern parts of Windsor and West Windsor and the northern part of Weathersfield. The geology of this area has been made known by R. A. Daly in an elaborate report already referred to. ${ }^{a}$ His map (Pl. VII) shows that Mount Ascutney, which lies about 5 miles southwest of Windsor village and rises 2,800 feet above the Connecticut and 3,100 feet above sea level, consists mainly of a mass, about $2 \frac{1}{2}$ miles square, of greenish hornblende-augite granite (syenite) intrusive in schists which crop out along its base. But adjoining this syenite on the west is an area of still older gneisses, which are intruded by a mass of gabbro and diorite about 2 by $1 \frac{1}{2}$ miles in area. That this intrusion is older than that of the syenite is shown by the fact that dikes of the syenite penetrate it. The syenite of Mount Ascutney was itself in turn intruded by a very irregular mass of biotite granite characterized by abundant dark segregations (knots) and covering about a square mile. This granite was formerly quarried and monuments of it can be seen in the Windsor cemetery.

$$
\text { "WINDSOR GRANITE." }
$$

"Windsor granite" (syenite, nordmarkite phase of Daly) is a hornblende-augite granite which when first quarried is of dark bluish-gray color, but after very brief exposure becomes dark olive 
green. Its texture is medium to coarse, with feldspars up to 0.3 and 0.5 inch and black silicates to 0.2 inch. Its constituents, in descending order of abundance, as made out from the study of four thin sections, two from each quarry, are: (1) Dark olive-green potash feldspar (orthoclase) minutely or obscurely intergrown with sodalime feldspar (certainly oligoclase in two of the slides), with cleavage planes stained with limonite; (2) dark smoky quartz with cavities (apparently without vacuoles, some of them of quartz crystal form) in streaks and sheets and crossed by intersecting cracks filled with limonite stain; (3) green hornblende; (4) augite, associated with or inclosed by (3); (5) biotite in very small quantity, in three slides none. The accessory minerals observed are titanite, magnetite or ilmenite, zircon, apatite, and allanite. The secondary are limonite and white mica in the feldspar.

The cause of the change in the color of the feldspar and thus of the granite upon exposure has already been referred to (p. 12). It does not effervesce with cold dilute muriatic acid. It is very hard and has a metallic ring under the hammer. It is brilliant in the rough from the cleavage faces of the large feldspars. Their shade is so dark that the black silicates only appear on close inspection. Owing to its extremely small content of mica it takes a very high polish, quite as high as that of the granite of Quincy. Its polished face is much darker than its rough face, but the hammered or cut face, being of medium greenish gray, is much lighter than either, so that lettering or carving stands out boldly on the polished face. (See PI. V, B.) It is best adapted for internal decorative use.

MOWER QUARRY.

The Mower quarry is on the west side of Mount Ascutney nearly $1 \frac{1}{4}$ miles south of Brownsville and 580 feet above it, in West Windsor. Operator, Ascutney Mountain Granite Company, Windsor, Vt.

The granite, already described, has received the trade name of "bronze vein green."

The opening, made in 1906, is about 50 feet square, and averages 10 feet in depth.

The sheets, 10 feet thick, are horizontal or dip $5^{\circ} \mathrm{W}$. There are three sets of joints: (a) Striking N. $85^{\circ}$ E. and vertical, is spaced 2 to 18 feet; (b) striking N. $30^{\circ} \mathrm{E}$, dips $75^{\circ} \mathrm{S} .60^{\circ} \mathrm{W}$., one forming the east wall; (c) striking N. $55^{\circ} \mathrm{W}$., dips $65^{\circ} \mathrm{N}$. $35^{\circ} \mathrm{E}$., one forming the south wall. The rift is reported as vertical with N. $85^{\circ} \mathrm{E}$. course and the grain as horizontal. There is a black bronzy streak dipping $45^{\circ} \mathrm{E}$., possibly of the black silicate, and showing the direction of flow. Light rusty brown and cream-colored discoloration is 0.5 inch thick on the joint faces. In thin section some of the limonite stain of this rim proceeds clearly from magnetite (or ilmenite), augite, and allanite particles. 
The plant at the quarry comprises three derricks (one of 20 tons and one hand), and two hoisting engines. At the cutting shed in Windsor it includes two hand derricks, an overhead 8-ton crane, a 50 -horsepower engine, an air compressor (capacity 125 cubic feet of air per minute), a cutting and a polishing lathe for stones 5 feet 6 inches by 1 foot 6 inches, and a set of twelve chilled shot saws for blocks 12 feet long.

Transportation is by gravity track 600 feet long and 30 per cent grade from the quarry to road and thence by cartage $8 \frac{1}{2}$ miles to Windsor.

The product is used mainly for dies, wainscoting, and indoor columns. Specimens: The two monolithic sarcophagi in the McKinley mausoleum at Canton, Ohio. When finished these measured 8 feet 10 inches by 4 feet 4 inches by 2 feet $6 \frac{3}{4}$ inches. The covers measured 9 feet $4 \frac{1}{2}$ inches by 4 feet $8 \frac{3}{4}$ inches by 1 foot $3 \frac{3}{4}$ inches. The polishing of these stones was done by another firm. The monument (Pl. V, $B$ ) shows the contrast between cut and polished faces, somewhat exaggerated in photographing, the black representing what is a dark olive green and the white what is a medium greenish gray.

\section{NORCROSS QUARRY.}

The Norcross quarry is on the north side of Mount Ascutney on the 1,350-foot level, about 950 feet above Windsor village, and a little over a mile east-southeast of Brownsville, in Windsor. Operator, Windsor Green Granite Company, Worcester, Mass.' This quarry is only operated occasionally.

The granite has been described on pages 116,117 .

The quarry is about 200 feet east to west by 40 feet across and has a working face 60 feet high on the south, with a rugged cliff above it, making a total face of 80 to 90 feet above the quarry bottom and road.

The sheets, from 2 to 10 feet thick, are horizontal or dip $10^{\circ} \mathrm{N}$. There are two sets of joints: (a), striking N. $75^{\circ}$ to $80^{\circ} \mathrm{E}$., vertical, is spaced 2 to 10 feet; (b), striking N. $.5^{\circ} \mathrm{W}$., vertical, is spaced 5 to 30 feet, with a 10 -foot wide heading through the center of the quarry. The splitting has been done in the direction of (a), which is the rift direction at the Mower quarry and presumably here also. 'There are many dark streaks: A 4-foot dike crosses the quarry parallel to and within heading (b). This appears to be also a hornblende-biotite granite. It is of medium greenish-gray color and of medium inclining to fine texture with feldspars mostly under 0.2 inch, rarely 0.4 inch, and black silicates mostly under 0.1 inch. Its constituents, in descending order of abundance, are: Greenish medium-gray potash feldspar with obscurely intergrown soda-lime feldspar, kaolinized; smoky quartz, more of it than in the adjacent granite; finely striated soda-lime feldspar (oligoclase-albite); hornblende; a little biotite. 
Accessory: Magnetite or ilmenite, titanite, and allanite. Secondary Kaolin.

The sheet surfaces, chiefly owing to the kaolinization of the feldspar, are discolored to a medium slightly greenish gray and the joint faces are similarly discolored, but with a limonitic border. The discoloration is from 1 to 1.5 inches thick.

The plant consists of three derricks, a hoisting engine and steam drill.

Transportation is by cartage to rail at Windsor.

The product has been used for monumental and decorative purposes. Specimens: Sixteen polished columns (24 feet $9 \frac{1}{2}$ inches by 3 feet 7 inches) in Columbia University Library, New York; monument to General Gómez in Cuba; a die in the Bennington monument; 34 large columns in the Bank of Montreal; columns and die of W. C. T. U. fountain, Orange, Mass.

\section{CHARACTERISTICS AND ADAPTATIONS OF VERMONT GRANITES.}

Although differing widely in their characteristics Vermont granites do not include a great variety of colors or texture. They are gray, whitish, and pinkish constructional granites of medium to coarse texture, gray monumental granites of fine to medium texture, and one dark-green polish and inscriptional granite of medium to coarse texture. Those which have thus far proved of principal economic importance are the gray monumental granites and the whitish constructional granite. The adaptability of "Barre granite" to sculpture is shown in the statue (Pl. III, $A$ ); that of the "Woodbury Bashaw" in the bas-relief (Pl. IV, $A$ ), and that of the coarse granite of Bethel in the eagle ( $\mathrm{Pl} . \mathrm{V}, A$ ). The suitableness of the green granite of Windsor for indoor decorative use and for inscriptions is shown in the polished and cut monument ( $\mathrm{Pl} . \mathrm{V}, B)$.

Among the notable buildings and monuments made of Vermont granite are the capitols of Vermont, Pennsylvania, and Wisconsin, the State Library and Supreme Court Building at Hartford, Conn., the Union Station and the first and second stories of the National Museum at Washington, D. C., the Cook County court-house at Chicago, Ill., the prison-ship martyrs' monument in Brooklyn, N. Y., and the sarcophagi for President and Mrs. McKinley at Canton, Ohio.

\section{CLASSIFICATION OF VERMONT GRANITES.}

In the following table all the granites described in this bulletin, except that of the Parmenter quarry, near Beebe Plain, are grouped by their economic uses. The trade name, the scientific name, the real general color and shade (without reference to spots or spangles), and the texture of each stone are given in separate columns, and page references to the descriptions of the stone and quarries are also added. 


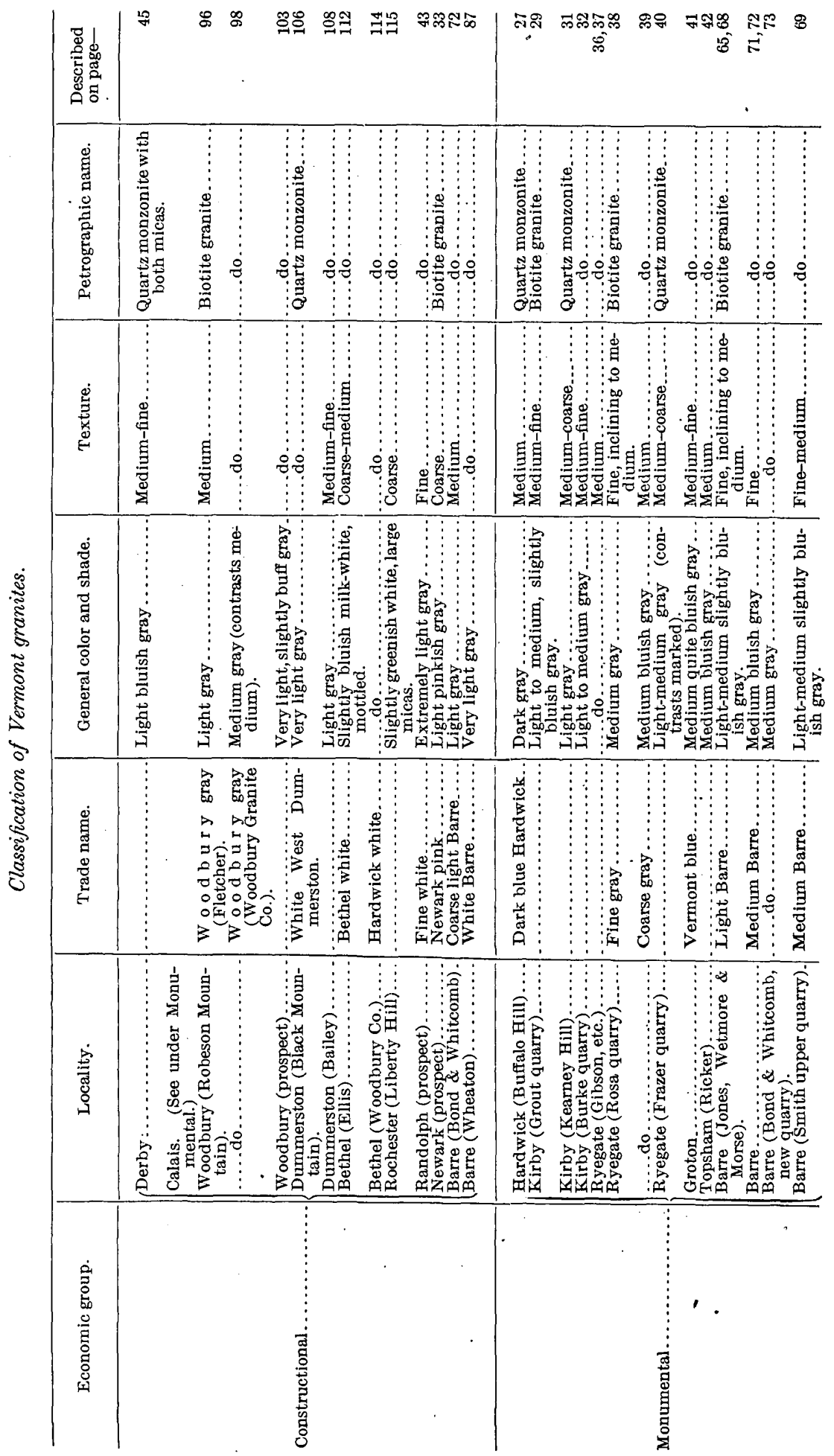




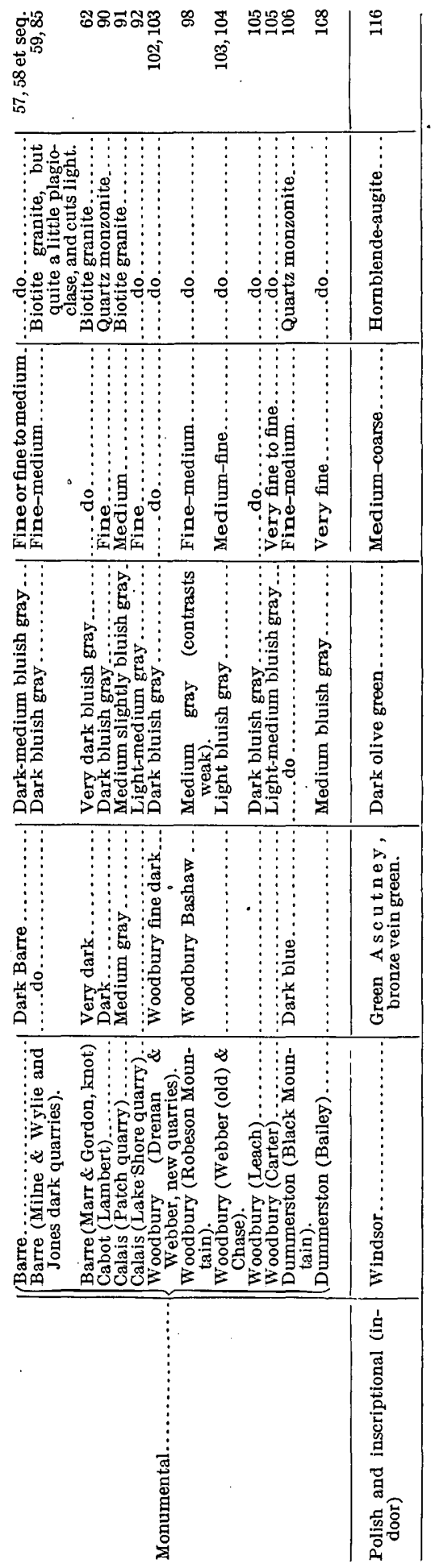




\section{COMMERCIAL VALUES OF VERMONT GRANITES.}

It is not within the province of this paper to give price lists, but as the current commercial value of a stone is a measure of its quality and an indication of the possibilities of its use a few prices of Vermont granites for 1907 are added. These prices are all for the rough stone and f. o. b.

The whitish quartz monzonite of Bethel is sold for constructional use at $\$ 1$ per cubic foot, ordinary sizes, and in selected blocks for monumental use at $\$ 2$. The very light gray quartz monzonite of Dummerston is 50 cents per cubic foot, random stock; and the light medium bluish gray from the same quarry for monumental use is 75 cents per cubic foot, ordinary sizes. The "Woodbury gray" constructional granite is 50 cents and the monumental granite from Woodbury ("Bashaw") 75 cents. Monumental granites of Barre range as follows for blocks of 80 cubic feet and under: "Light," $\$ 1.15$; "medium," \$1.25; "dark medium," \$1.40; "dark," \$1.50. Barre constructional, "coarse light" (Bond \& Whitcomb), sells at 25 cents, dimension stone. The gray monumental granites of South Ryegate are 45 cents, ordinary sizes. The green polish and inscriptional syenite of Windsor sells for $\$ 1.50$. In 1909 the very light of Beebe Plain was selling at 40 cents per cubic foot, f. o. b. cars at North Derby.

Summarizing, the constructional granites range from 25 cents to $\$ 1$ per cubic foot; the monumental from 75 cents to $\$ 2$. The polish and inscriptional are $\$ 1.50$ per cubic foot.

\section{STATISTICS OF GRANITE PRODUCTION IN̂ VERMONT.}

By Altha T. Coons.

The first statistical work on Vermont granite by the United States Geological Survey was done in connection with the Tenth Census, and gave the output of granite for the year ending May 31, 1880. There were 12 quarries reporting for that year, and the total output was 187,140 cubic feet, valued at $\$ 59,675$. The next figures available for Vermont granite were for 1886, when the output, chiefly monumental stone from the Barre quarries, was reported as 240,000 cubic feet, valued at $\$ 180,000$. The year 1887 represented a gain of 25 per cent over the output for 1886, and was 300,000 cubic feet, valued at $\$ 225,000$. The Eleventh Census gave the output of granite for the census year as valued at $\$ 581,870$, and the Twelfth Census gave an output for the year 1902, the product of 68 quarries; valued at $\$ 1,570,423$, an increase of 169.9 per cent in thirteen years, or of 2,531.6 per cent for the twenty-three years, represented by different census figures. From the time of the Eleventh Census, the statistics of Vermont granite production have been regularly collected, the 
entire output increasing steadily, although not regularly, as the years were more or less differently affected by labor troubles, chiefly in the building trades. The stone of the State was at first chiefly used for monumental work, but recently a large quantity has been used in building, a small quantity made into paving blocks, and equally small quantities were sold as crushed stone for road making, ballast, curbing, etc.

The following table shows the value of the granite produced in Vermont, as compiled by the United States Geological Survey from 1880 to 1907 :

Production of granite in Vermont.from 1880 to 1907.

\begin{tabular}{|c|c|c|c|c|c|c|c|c|}
\hline \multirow{2}{*}{ Year. } & \multicolumn{2}{|c|}{ Roungh. } & \multicolumn{2}{|c|}{ Dressed. } & \multicolumn{2}{|c|}{ Paving. } & \multirow{2}{*}{$\begin{array}{l}\text { Other } \\
\text { pur- } \\
\text { poses. } a\end{array}$} & \multirow{2}{*}{$\begin{array}{l}\text { Total } \\
\text { value. }\end{array}$} \\
\hline & Building. & $\begin{array}{l}\text { Monu- } \\
\text { mental. }\end{array}$ & Building. & $\begin{array}{l}\text { Monu- } \\
\text { mental. }\end{array}$ & $\begin{array}{l}\text { Number } \\
\text { of blocks. }\end{array}$ & Value. & & \\
\hline 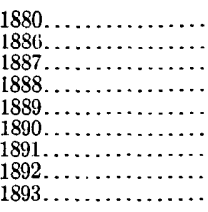 & & $\because$ & & & & & 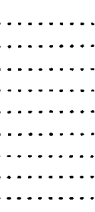 & $\begin{array}{l}\$ 59,675 \\
180,000 \\
225,000 \\
279,000 \\
581,870 \\
610,963 \\
700,000 \\
675,000 \\
778,459\end{array}$ \\
\hline $\begin{array}{l}1894 \ldots \ldots \ldots \ldots \ldots \\
1895 \ldots \ldots \ldots \ldots \ldots \\
1896 \ldots \ldots \ldots \ldots \ldots\end{array}$ & & & $\begin{array}{r}1,245 \\
7,016 \\
4,526 \\
\end{array}$ & & & $\begin{array}{r}\$ 32,711 \\
30,702 \\
30,990\end{array}$ & $\ldots \ldots \ldots$ & $\begin{array}{r}893,956 \\
1,007,718 \\
895,516\end{array}$ \\
\hline $\begin{array}{l}1897 \ldots \ldots \ldots \ldots \ldots \ldots \\
1898 \ldots \ldots \ldots \ldots \ldots \ldots \\
1899 \ldots \ldots \ldots \ldots \ldots \\
1900 \ldots \ldots \ldots \ldots \ldots\end{array}$ & $\begin{array}{r}\$ 430 \\
531 \\
563 \\
526 \\
\end{array}$ & $\begin{array}{l}, 121 \\
, 634 \\
, 475 \\
370\end{array}$ & $\begin{array}{r}\$ 283,167 \\
113,922 \\
125,775 \\
49,763\end{array}$ & $\begin{array}{r}\$ 341,034 \\
416,878 \\
509,358 \\
527,053\end{array}$ & & $\begin{array}{r}16,770 \\
4,446 \\
3,500 \\
225\end{array}$ & $\begin{array}{l}\$ 3,208 \\
17,338 \\
10,859 \\
10,377\end{array}$ & $\begin{array}{l}1,074,300 \\
1,084,218 \\
1,212,967 \\
1,113,788\end{array}$ \\
\hline $\begin{array}{l}1901 \ldots \ldots \ldots \\
1902 \ldots \ldots \ldots \\
1903 \ldots \ldots \ldots \\
1904 \ldots \ldots \\
1905 \ldots \ldots \ldots \\
1906 \ldots \ldots \ldots \\
1907 \ldots \ldots \ldots \ldots\end{array}$ & $\begin{array}{r}\$ 208,825 \\
28,845 \\
103,353 \\
83,148 \\
188,391 \\
47,154 \\
29,764\end{array}$ & $\begin{array}{r}\$ 534,755 \\
756,007 \\
828,508 \\
797,830 \\
778,681 \\
993,220 \\
1,122,063\end{array}$ & $\begin{array}{r}16,343 \\
289,567 \\
346,293 \\
912,801 \\
1,093,688 \\
1,422,862 \\
1,009,353\end{array}$ & $\begin{array}{l}354,563 \\
453,187 \\
481,346 \\
615,057 \\
471,093 \\
451,222 \\
515,859\end{array}$ & $\begin{array}{l}\ldots \ldots \ldots \ldots \\
\cdots \ldots \ldots \ldots \\
382,758 \\
413,898 \\
282,930 \\
171,000\end{array}$ & $\begin{array}{r}16,304 \\
2,855 \\
28,839 \\
14,745 \\
16,628 \\
9,557 \\
5,330\end{array}$ & $\begin{array}{r}115,038 \\
39,962 \\
21,840 \\
24,398 \\
23,369 \\
10,810 \\
11,520\end{array}$ & $\begin{array}{l}1,245,828 \\
1,570,423 \\
1,810,179 \\
2,447,979 \\
2,571,850 \\
2,934,825 \\
2,693,889\end{array}$ \\
\hline
\end{tabular}

a Includes stone for roads, curbing, ballast, etc.

The figures as given in the table show the values obtained free on board by the quarrymen for the stone quarried by them, and do not represent the stone sold by manufacturers. When quarrymen dress their own stone, the value of the dressed stone is given as representing the value of the material to the quarrymen. For the years 1906 and 1907, it has been possible to tabulate the quantity of stone sold for building and for monumental work. This is of interest as showing the proportion of stone sold for building and for monumental purposes, and also showing practically the number of cubic feet of granite sold in Vermont for these years, the quantity of stone for other purposes being almost negligible.

The following table shows the production of granite in Vermont in 1906 and 1907 by counties and uses, and also the total value for the United States for the same interval: 


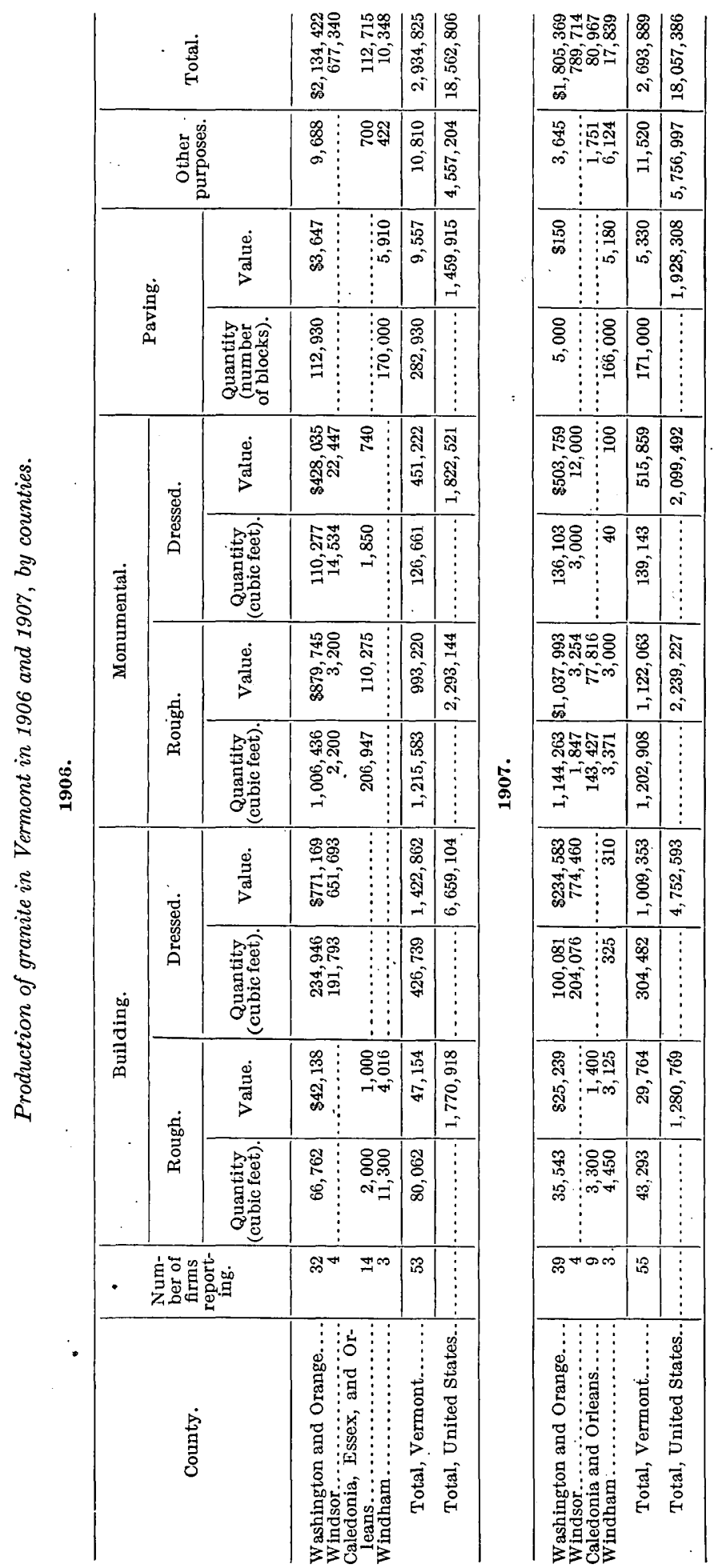


In 1907 the total value of the granite produced in the United States was $\$ 18,057,386$, which; compared with the total value for Vermont of $\$ 2,693,889$, shows that in this year Vermont produced 14.92 per cent of the total value of granite sold in the United States. In 1907 Vermont ranked first in the value of output, followed by Massachusetts and Maine with productions valued at $\$ 2,328,777$ and $\$ 2,162,277$, respectively. In 1906 Vermont ranked second in the value of production, the value for this year of $\$ 2,934,825$ being exceeded by Massachusetts with an output valued at $\$ 3,327,416$ and followed by Maine with an output of $\$ 2,560,021$, the total output of granite for Vermont in 1906 being 15.81 per cent of the total of the United States.

The total value of granite sold, rough and dressed, by the quarrymen for building stone in the United States in 1906 was $\$ 8,430,022$, of which Vermont's share was $\$ 1,470,016$, or 17.44 per cent of the total. In 1907 the total for the United States was $\$ 6,033,362$, with Vermont representing $\$ 1,039,117$, or 17.20 per cent of the total. The total value of granite, including rough and dressed stone as sold by the quarrymen in the United States for monumental work, was, in $1906, \$ 4,115,665$, Vermont's production being valued at $\$ 1,444,442$, or 35.10 per cent. In 1907 this total was $\$ 4,338,719$, Vermont representing $\$ 1,637,922$, or 37.75 per cent. The value of the total granite output for Vermont decreased somewhat in 1907 as compared with 1906 , or from $\$ 2,934,825$ in 1906 to $\$ 2,693,8 \$ 9$ in 1907 , a decrease of $\$ 240,936$. The principal decrease was in the value of the building stone sold, which, including rough and dressed stone, was from a value of $\$ 1,470,016$ in 1906 to $\$ 1,039,117$ in 1907 , a loss of $\$ 430,899$. The total monumental stone, however, increased from a value of $\$ 1,444,442$ in 1906 to $\$ 1,637,922$ in 1907 , a gain of $\$ 193,480$. The loss in building stone production was due to financial depression affecting general building conditions, especially in large cities.

In 1906, of the $1,849,045$ cubic feet of stone sold for building and monumental work, the quantity for building purposes alone was 506,801 cubic feet, or 27.41 per cent of the total, while $1,342,244$ cubic feet, or 72.59 per cent of the total was for monumental stone. The value, however, reported for the building stone, rough and dressed, was $\$ 1,470,016$, or 50.44 per cent of the total, and for the monumental stone $\$ 1,444,442$, or 49.56 per cent of the total, these percentages being nearly the same, while the quantity of monumental stone was over two and one-half times as much as the quantity sold for building work. This is accounted for from the fact that by far the greater part of the monumental stone was sold to the manufacturers to be dressed, while the producers of building stone dressed their own material. The average price per cubic foot of rough building stone in 1906 was 59 
cents; dressed, $\$ 3.33$. The average price per cubic foot of rough monumental stone in 1906 was 82 cents; dressed $\$ 3.56$.

In the same manner the total quantity of building and monumental stone for 1907 amounted to $1,689,826$ cubic feet; 347,775 cubic feet, or 20.58 per cent being building stone, and 1,342,051 cubic feet, or 79.42 per cent, being monumental stone. The total value of building and monumental stone was $\$ 2,677,039$, and of this $\$ 1,039,117$, or 38.82 per cent, was the value for building stone, and $\$ 1,637,922$, or 61.18 per cent, the value of monumental stone. The average price per cubic foot of rough building stone in 1907 was 69 cents; dressed stone, $\$ 3.31$; and the average price per cubic foot of rough monumental stone was 93 cents; dressed stone, $\$ 3.71$.

The total quantity and value of building and monumental stone sold in 1907 decreased 159,219 cubic feet in quantity and $\$ 237,419$ in value as compared with 1906; or from 1,849,045 cubic feet, valued at $\$ 2,914,458$, in 1906 , to $1,689,826$ cubic feet, valued at $\$ 2,677,039$, in 1907 . The decrease was in the quantity and value of building stone, which amounted to 506,801 cubic feet, valued at $\$ 1,470,016$, in 1906 , and 347,775 cubic feet; valued at $\$ 1,039,117$, in 1907 , a decrease of 159,026 cubic feet in quantity and $\$ 430,899$ in value. This is accounted for by the general depression in the building trade, fewer contracts being given to or taken by the quarrymen on account of the financial depression. In 1906 the output of monumental stone was $1,342,244$ cubic feet, valued at $\$ 1,444,442$, and in 1907 it was $1,342,051$ cubic feet, valued at $\$ 1,637,922$, a decrease of 193 cubic feet in quantity and an increase in value of $\$ 193,480$.

The largest output is from Washington County, and includes the towns of Barre, Calais, and Woodbury. Windsor County has the next largest production, the output being from Bethel, Chester, and Windsor. The Caledonia County output ranks next and includes Kirby, Groton, Hardwick, and Ryegate. The Windham County output comes from Dummerston. The other localities giving smaller outputs, representing not more than one firm,' are in Williamstown, Orange County, and Derby, Orleans County.

\section{METHODS IN THE USE OF EXPLOSIVES.}

In Bulletin 313 (pp. 69-72) the methods in the use of explosives prevalent among Maine quarrymen were given, and in Bulletin 354 (pp. 70-72) additional data of the same sort, gathered in the granite quarries of Massachusetts, New Hampshire, and Rhode Island, were published. There is but little to add on this subject from the Vermont quarries.

At Barre, wherever the sheets are imperfectly developed, this methor is adopted: A thick rectangular block is obtained by channeling along a vertical rift, and also at two points along the hard way, at 
right angles to the rift, the fourth side being that of a joint or heading. An artificial sheet parting is then made by drilling divergent holes 10 feet deep along a horizontal grain. These holes taper from $1 \frac{1}{2}$ inches to 1 inch and are filled with but small charges of powder.

\section{BIBLIOGRAPHY OF ECONOMIC GEOLOGY OF GRANITE}

Buckley, Ernest B. Building and ornamental stones of Wisconsin: Bull. Wisconsin Geol. and Nat. Hist. Survey, No. 4, Madison, Wis., 1898. Granite, pp. 88-100, 107-115, 121-160; tests, pp. 46-74, 358-4.15.

Buckley, Ernest B., and Buehler, H. A. The quarrying industry of Missouri: Missouri Bureau of Geol. and Mines. 2d series, vol. 2. 1904. Granite, pp. 60-85.

Clark, William B., and Mathews, Edward B. Report on the physical features of Maryland, together with an account of the exhibits of Maryland mineral resources by the Maryland Geol. Survey. Maryland Geol. Survey (special publication, vol. 6). 1906. The granites, pp.. 115, 144, 173-177, Pl. VIII; fig. 1. Pl. XII.

Coons, Altha T. The stone industry in 1904: Min. Res. U. S. for 1904. 1905. Granite, pp. 17-32. (See also Min. Res. U. S. for 1905-1908.)

Dale; T. Nelson. The granites of Maine, with an introduction by George Otis Smith: Bull. U. S. Geol. Survey No. 313, 1907, pp. 63-189.

The chief commercial granites of Massachusetts, New Hampshire, and Rhode Island. Bull. U. S. Geol. Survey No. 354, 1908, pp. 65-220.

Daw, A. W. and Z. W. The blasting of rock in mines, quarries, and tunnels [etc.]. Pt. I:-The principles of rock blasting and their general application. London, 1.898.

Day, William C. Stone: Min. Res. U. S. Twenty-first and prior Ann. Repts. U. S. Geol. Survey. Granite.

Gillette, H. P. Rock excavations: Methods and cost. New York, 1.904.

Gillmore, Q. A. Report on the compressive strength, specific gravity, and ratio of absorption of various kinds of building stones from different sections of the United States tested at Fort Tompkins, Staten Island, N. Y. Engineer Department, U. S. Army. 1874.

Guttman, Oscar. Handbuch der Sprengarbeit. Braunschweig, 1892.

Harris, G. F. Granite and our granite industries. London, 1888.

Hirschwald, J. . Die Prüfung der natürlichen Bausteine auf ihre Wetterbeständigkeit. Berlin, 1908. Abstract in Zeitschr. prakt. Geologie. July-Sept. and Nov., 1908. (See note at end of this bibliography.)

Henning, G. C. Diamond tools. Trans. Am. Soc. Mech. Eng., vol. 26, 1904, pp. 409-417.

- Herrmann, O. Steinbruchindustrie und Steinbruchgeologie. Berlin, 1899.

Technische Verwerthung der Lausitzer Granite. Zeitschr. prakt. Geologie, November, 1895 (II), pp. 433-444.

Hull, Edward. A treatise on the building and ornamental stones of Great Britain and foreign countries. London, 1872 .

Humphrey, Richard L. Fire-resistive properties of various building materials. Tests by U. S. Geol. Survey. Bull. U. S. Geol. Survey. No. 370, 1909, pp. 69-72.

Julien, Alexis A. Building stones; elements of strength in their constitution and structure: Jour. Franklin Inst., Pennsylvania, vol. 147, No. 4. April, 1899, pp. 257-442. 
Julien, Alexis A. Comparison of methods of graphic analysis of rocks. Bull. Geol. Soc. America, vol. 14, pp. 460-468. 1903.

Lord, E. C. E. Examination and classification of rocks for road building, including the physical properties of rocks with reference to their mineral composition and structure. U. S. Dept. of Agriculture, Office of Public Roads, Bull. 31, 1907. Physical properties of granite for road making. Table 2.

Lundbohm, Hjalmar. Summary of his various papers on granite and granite quarrying in Europe, by William C. Day: Min. Res. U. S. for 1893. U. S. Geol. Survey, 1894.

Mathews, Edward B. The granite quarries of Maryland: Rept. Maryland Geol. Survey, vol. 2, 1898, pp. 136-160.

Mathews, Samuel W. The granite industry of Maine: Sixteenth Ann. Rept. Bureau of Industrial and Labor Statistics for the State of Maine, 1902, pp. 7-51.

McCourt, W. E. Fire tests of some New York building stones. N. Y. State Mus. Bull. No. 100, 1906 . Granite and gneiss: pp. 13, 16-19, 26-27, 29-32, pls. 1-3, 9-11, 14-17.

The fire-resisting qualities of some New Jersey building stones. Ann. Rept. State Geologist, Geol. Survey of New Jersey. 1906. Granites and gneisses: pp. $26-28$.

Merrill, George P. On the collection of Maine building stones in the United States National Museum: Proc. U. S. Nat. Mus., vol. 6, 1883, pp. 165-183.

Collection of building and ornamental stones in the United States National Museum: A.nn. Rept. Smithsonian Inst., 1886, pt. 2, 1889.

Physical, chemical, and economic properties of building stones: Rept. Maryland Geol. Survey, vol. 2, 1898, pp. 47-123.

Stones for building and decoration, $3 \mathrm{~d}$ ed. New York, 1903.

Stone (granite): Special reports of the Census Office, Twelfth Census; mines and quarries. (1902.) 1905.

Newberry, J. S. Report on building stones of the U. S. and statistics of the quarry industry. Census U. S. 10th Rept., vol. 10, 1884, pp. 318-324.

Perkins, George H. Report on the marble, slate, and granite industries of Vermont, 1898. Granite, pp. 51-68.

Report of state geologist on the mineral resources of Vermont, 1899-1900. Granite, pp. 57-77.

Report of state geologist on the mineral industries and geology of certain areas of Vermont, 1903-4. 1904. Granite, pp. 23-44.

Report of state geologist on the mineral industries and geology of certain areas of Vermont, 1907-8. 1908. Granite, pp. 32-46.

Reusch, Hans. Granite industrien ved Idefjorden, etc. Norges geologiske undersögelse: Aarbog for 1891. Kristiania; 1891.

Rich, George. The granite industry of New England: New England Magazine, February, 1892, p. 742 .

Ries, Heinrich. Economic geology of the U. S. New York, 1905. Chap. III: Building stones. Granite, pp. 75-78.

Riiber, Carl C. Norges granit industri: Norges geologiske undersögelse No. 12: Aarbog for 1893, with English summary.

Rosiwal, August. Ueber geometrische Gssteinsanalysen. Ein einfacher Weg zur ziffermässigen Feststellung des Quantitätsverhältnisses der.Mineralbestand theile gemengter Gesteine: Verh. der K.-k. geol. Reichsanstalt, vol. 32, 1898, pp. 143-175. 
Rosiwal, August. Ueber einige neue Ergebnisse der technischen Untersuchung von Steinbaumaterialien. Eine neue Methode zur Erlangung zahlenmässiger Werte für die "Frische" und den "Verwitterungsgrad" der Gesteine: Verhandll. K.-k. geol. Reichsanstalt, vol. 33, 1899, pp. 204-225.

Ueber weitere Ergebnisse der technischen Untersuchung zur Erlangung zahlenmässiger Werte für die "Zähigkeit" der Gesteine: Verhandl. K.-k. geol. Reichsanstalt, 1902, pp. 234-246.

Schmidt. Natürliche Bausteine. (Vol. 76, Bibl. d. gesammten Technik.) Hannover, 1908.

Smith, Walter B. Methods of quarrying, cutting, and polishing granite. Mineral Industries: Eleventh Census, U. S. (1892), pp. 612-618. Also Sixteenth Ann. Rept. U. S. Geol. Survey, pt. 4, pp. 446-456.

Speer, F. W. Quarry methods: Tenth Census, U. S., vol. 10, 1888, pp. 33 et seq.

Tarr, Ralph S. Economic geology of the United States, with briefer mention of foreign mineral products, $2 \mathrm{~d}$ ed., New York, 1895.

Watson, Thomas Leonard. A preliminary report on a part of the granites and gneisses of Georgia: Bull. 9 A, Georgia Geol. Survey, 1902.

Watson, Thomas Leonard, and Laney, Francis B., with the collaboration of George P. Merrill. The building and ornamental stones of North Carolina: Bull. North Carolina Geol. Survey No. 2, 1906.

Weidman, Samuel. The geology of north central Wisconsin. Bull. Wisconsin Geol. and Nat. Hist. Survey No. 16. Madison, 1907. Granite quarries, pp. 636-640. Analyses of granite from central and southern Wisconsin, p. 340; from northern Michigan and northern Minnesota, p. 341. Disintegrated granitc for country roads, p. 643.

Williams, Ira A. The comparative accuracy of the methods for determining the percentages of the several components of an igneous rock: Am. Geologist, vol. 35, January, 1905.

Wolff, John E. Details regarding quarries (granite): Tenth Census, vol. 10, 1888.

See also the successive reports of the tests of metals and other materials for industrial purposes made at Watertown Arsenal, published by the United States War Department.

The German periodicals named below also give results of tests of granite:

Mitteilungen der technischen Versuchsanstalten zu Berlin.

Mitteilungen der Anstalt zur Prüfung von Baumaterialien am Polytechnikum in Zurich.

Mitteilungen aus dem mechanisch-technischen Laboratorium der Königlichen technischen Hochschule in München.

The substance of the paper by Merrill in vol. 10 of the United States Tenth Census, 1888, and by Merrill in the Proceedings of the U. S. National Museum, vol. 6, 1883, has reappeared in more modern form in his other works.

The work of Hirschwald in the above bibliography is of special interest, as its conclusions are based upon the microscopic study of specimens taken from buildings none of them less than fifty years old and a number several centuries old.

4782-Bull. 404-09-9 


\section{GLOSSARY OF SCIENTIFIC AND QUARRY TERMS.}

ACCESSORY MINERALS in granite are original constituents of the rock, found only in small, often only in microscopic quantity.

AcIDIc. A term applied to rocks in which silicic acid (silica) or quartz predominates.

Allanite. An opaque black mineral (silicate), brown in thin section, one of the primary less common accessory constituents of granite, which contains from 12 to 17 elements, including 6 of the rarer ones. For analyses see Dana, E. S., System of Mineralogy, 6th ed. 1892.

Anticline. A term applied to granite sheets or sedimentary beds that form an arch.

Apurte. Fine-grained granite, usually occurring in dikes and containing little mica and a high percentage of silica.

BAsrc. A term applied to rocks in which the iron-magnesia minerals and feldspars with lime and soda predominate, such as diabase or basalts.

BLACK HoRse. Term used by quarrymen in Rhode Island to denote a dark biotite gneiss in contact with the granite.

BLind seams. Quarrymen's term for incipient joints.

Bowlder qUARRY. One in which the joints are either so close or so irregular that no very large blocks of stone can be quarried.

Channel. A narrow artificial incision across a mass of rock, which, in the case of a granite sheet, is made either by a series of contiguous drill holes or by blasting a series of holes arranged in zigzag order.

Cleavage, when applied to a mineral, designates a structure consequent upon the geometrical arrangement of its molecules at the time of its crystallization.

Close-Jointed. A term applied to joints that are very near together.

Crinoid stem. Part of the calcareous skeleton of a plantlike marine animal related to "starfishes" and "sea urchins," but rooted and provided with an articulated stem, bearing a cup containing the alimentary organs.

Crocus. A term used in the Milford, N. H., quarries to denote gneiss or any other rock in contact with granite.

CrUSh-Border. A microscopic granular structure sometimes characterizing adjacent feldspar particles in granite in consequence of their having been crushed together during or subsequent to their crystallization.

CuT-ofF. Quarrymen's term for the direction along which the granite must be channeled, because it will not split. Same as "hard way."

DENDrites. Plantlike crystallization of iron or manganese oxides on the surfaces of fissures in any rock or mineral. Frost crystals on window panes are of like character .

Drke. A mass of granite, diabase, basalt, or other rock which has been erupted through a narrow fissure.

Dimension stone. A term applied to stones that are quarried of required dimensions.

Dir. The inclination from the horizon, given in terms of degrees, of a sheet, joint, heading, dike, or other structural plane in a rock.

DRIFT. Sand and bowlders deposited by the continental glacier.

Drumuin. Oval hillock of clay and bowlders formed beneath the ice sheet of the glacial epoch.

Erosion. The wearing away of portions of a rock by such natural agencies as stream or ice action.

Exfoliation. The peeling of a rock surface in sheets owing to changes of temperature or other causes. 
Faulting. The slippage of a rock mass or masses along a natural fracture.

Flow-structure. The parallel arrangement of the minerals in granite or other igneous rock in the direction of its flowage during its intrusion.

Geode. A rock cavity lined with crystals. Geodes in granite are attributed to steam or gas bubbles.

GraIN in granite is practically the direction in which the stone splits "next easiest," the "rift" being that in which it splits most readily.

Graptolite. An extinct marine plantlike communal animal organism related to the early stage of certain "jelly fish." They were probably attached to seaweeds.

Grout. A term applied to the waste material of all sizes obtained in quarrying stone.

Grow-on. Quarrymen's term to designate the place where the sheet structure dies out, or the place where two sheets appear to grow on to one another.

HARD-WAY. The direction at right angles to both rift and grain in which granite does not split readily. (See Cut-off.)

Heading. A collection of close joints.

Heading-seam. See Joint.

Hematite. An oxide of iron $\left(\mathrm{Fe}_{2} \mathrm{O}_{3}\right)$ which when scratched or powdered gives a cherry-red color.

IGNEOUS. A term applied to rocks that have originated in a molten condition.

Jornts. More or less steeply inclined fractures which cross the granite sheets and which are attributed to various stresses.

Kaolin. A hydrous silicate of alumina derived from the alteration of feldspar.

Kaolinization. The process by which a feldspar passes into kaolin.

Knots. A term applied by quarrymen to dark gray or black objects, more or less oval or circular in cross-section, which are segregations of black mica or hornblende formed in the granite while in a molten state. English quarrymen call them "heathen."

KNox Hole. A circular drill hole with two opposite vertical grooves which direct the explosive power of the blast.

LEwIS HoLE. An opening made by drilling two or three holes near together and chiseling out the intervening rock.

Limonite. A hydrous oxide of iron $\left(2 \mathrm{Fe}_{2} \mathrm{O}_{3}, 3 \mathrm{H}_{2} \mathrm{O}\right)$; a hydrated hematite, which, when scratched or powdered, gives a brownish rust color.

Matrix. The general mass of a rock which has isolated crystals; sometimes called groundmass.

Millimeter. French decimal lineal measure, the thousandth part of a meter or the tenth part of a centimeter. It is nearly equivalent to 0.04 inch, the meter being $39 \frac{10}{2}$ inches.

Monolith. A column or monument of one stone.

Motron. A term used in granite regions to designate small paving-block quarries.

OpHiric. A term applied to microscopic rock texture to designate a mass of longish interlacing crystals, the spaces between which have been filled with minerals of later crystallization.

Oreï. A term applied in the Quincy quarries to granite which has been rendered valueless by the alteration of its ægirite particles.

Pegmatite. A very coarse granite occurrring in irregular dikes or lenses in granites and some other rocks.

Plagioclase. A term applied to all those feldspars that are not potash feldspars. 
Pneumatolytic. A term used by geologists to designate those minerals which are formed by superheated mineral solutions associated with the intrusion or eruption of igneous rocks.

Polarized light. Light whose vibrations, unlike those of ordinary light, which are in all directions, are in only one plane. Polarized light is used in the microscopic study of rocks.

Porphyritic. A term applied to rock texture to designate the presence of isolated crystals in a general mass (matrix or groundmass) of finer material.

PseudomorpH. Signifies false form, and designates a crystal in which, owing to various chemical changes, the original mineral has been more or less replaced by others. The form of the crystal no longer corresponds to the mineral.

Quartz monzonite. Technical designation for a granite in which the percentages of soda-lime and of potash feldspar are nearly the same or in which the former exceeds the latter. In ordinary granites the amount of soda-lime feldspar is relatively small.

RANDom STONe. A term applied by quarrymen to quarried blocks of any dimensions. (See definition of dimension stone.)

RIFT. A quarrymen's term to designate an obscure microscopic cleavage in granite which greatly facilitates quarrying.

Run. A term used by quarrymen in connection with "rift," apparently to denote the course of the deflection of the rift due to gravity, strain, or other not yet understood cause.

SALT-HORSE. Quarrymen's term for aplite.

SAND SEAMS. Quarry term for more or less minute veins or dikes of muscovite (white mica) with some quartz, in cases also with feldspar.

SAND streaks. Same as sand seams.

$\dot{S}_{A P}$. Quarrymen's term for ferruginous discoloration along sheet or joint surfaces.

ScHIst. A rock made up of flattish particles arranged in rough parallelism, some or all of which have crystallized under pressure.

Schis'osity. The quality of being like a schist.

SEAM. Quarrymen's term for joint.

Secondary minerals. Minerals whose presence is due to the alteration of the original minerals.

Sedimentary. A term designating those rocks that consist of particles deposited under water.

Segregation. The scientific term for "knot;" a collection of material separated from other material. A vEIN OF SEGREGATION is one formed by the filling of a fissure with mineral matter originating in the surrounding rock.

Sericite. A more or less fibrous form of muscovite (potash mica), often resulting from the alteration of feldspar.

ShaKes. Quarrymen's term to designate a somewhat minute close-joint structure, which forms along the sheet surface as a result of weathering (?).

SheEt quarry. A quarry in which the granite lies in sheets, crossed by wide-spaced steep joints.

Suickensides. The polished and grooved faces of a joint or bed caused by motion and friction.

STRAIN-SHEET. Quarrymen's term for granite sheets produced by present compressive strain. 
STratried. A term applied to rock consisting of originally horizontal beds or strata.

STRIKE. The direction at right angles to the inclination of a plane of bedding, a sheet, or joint, etc.

Stripping. The material (sand, clay, soil, etc.) overlying a rock of economic value, which must be removed before quarrying.

Specric GRAVITY. The weight of a rock or mineral compared to that of a body of distilled water of the same bulk.

SubJoInt. Minor joints diverging from or parallel to the regular joints.

Synchine. A geological term for the trough part of a wave-like sheet or bed of rock.

Trghtset. Quarrymen's term, equivalent to blind seam, an incipient joint, in places associated with microscopic quartz veins.

Till. A mixture of clay and bowlders deposited by glaciers.

ToeIng-IN. Quarrymen's term for the wedging in of the end of a granite sheet under an overhanging joint, probably in consequence of the faulting of the sheets along the joint. It is also applied to the overlapping of lenticular sheets.

"Toe NaILs." Curved joints intersecting the sheet structure, in most cases striking with the sheets, in some differing from them in strike $45^{\circ}$ or more.

Twin crystals. Two adjacent crystals which have formed with the poles of their main axes in opposite or different directions.

WeATHERING. The decomposition of a rock owing to the action of the weather.

White Horse. Term used by quarrymen to denote a light-colored gneiss, aplite, or pegmatite. 



\section{INDEX.}

$A$.

Acme granite quarry, description of........ 68

Adamant. geology at.................... 13

quarries at........................ $90-92$

$\Lambda$ daptations, range of................... $\quad 119$

Ainsworth \& Ainsworth, quarry of ........ 101

Ainsworth quarry, description of ......... 101

Anderson quarry, contacts in.............. 21

contacts in, figures showing.......... 22.23

description of ...................... 63-04

Aplite, intrusion of ..................... 16

Ascutney, Mount, geology of. ........... 14, 116

granite of, carving of, view of.......... 112 composition of.................... 12,116

Ascutney Mountain Granite Co., quarry of.. 117

B.

Bailey, D. J., prospects of .............. 108-109

Bailey quarry, contact in.................. 23

description of . . . . . . . .

Barclay Brothers, quarry of .............. 67

Barclay quarry, description of............. 67-(is

Barney, Augusta, quarry of.............. 74

Barney quarry, description of............. 74

structure of, figure showing............ 74

Barre, dikes at........................ 49,55

geology at..................... 13, 14,48-49

granite at, inclusions in .............. 18

inclusions in, view of .............. 50

granite contacts at................. 21-23

figure showing................... 22

intrusion at........................ 24-25

quarries of........................... 47

description of................... 57-89

geology of .................... 17,52-57

map of........................ 48

sheeting in .................... 52-53

strain in ........................ 17

quarry methods at................ 120-127

topography at.................. 47, 48-49

figure showing.................... 47

Barre granite, analysis of . ............... 51-52

description of ..................... 11,50-52

statue of, view of ................... 68

Barre Granite and Quarry Co., quarry of.... $\quad 74$

Barre Granite Co., quarry of................ 63

Barre Granite Co.'s quarry, description of ...

Barre Medium Granite Co., quarry of...... 84

Barre Medium quarry, description of....... 84

Barre quarry, description of.............. 83

Barre Quarry Co., quarry of............... 83

Barre White Granite Co., quarry of.......... $\quad 87$

Beedle, A. II., prospect of ................. . 43

Benzie quarry, description of ............. 40-42 strains in ...................... $17-18,42$ structure in. figure showing.
Bethel Town, geology in ...........13,14, 109-112

granite contacts in ............... 20-21,24

figures showing................ 20,21

granite of, carving of, view of......... 112

composition of ................... 11

nodules in....................... 26

view of ..................... 50

strain in $\ldots \ldots \ldots \ldots \ldots \ldots \ldots \ldots . \quad 17$

map of.......................... 110

Bethel granite, analysis of............... 111

description of. .................. 110-112

physical characteristics of ............ 111-112

Bianchi, C. B., quarry of ................. 89

Bianchi quarry, description of............ $\quad 89$

Bibliography of granite............... 127-129

Biotite granite, composition of............. 11

Black Mountain, quarries on ........... 105-108

sheeting at, view of................. 68

strain on .......................... 18

Black Mountain quarry, description of... 106-108 sheets in, view of ..................... 68

Blue Mountain, geology on ............... 13

inclusions on ....................... 19

quarries on ........................ $30-40$

strain on .......................... 18

Bond \& Whitcomb, quarry of............ 72

Bond \& Whitcomb quarry, description of... 72-73

Boutwell, Milne \& Varnum, quarries of. . $57,60,61$

Boutwell quarry, description of........... 57-58

granite of, inclusions in............. 18-19

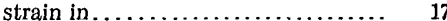

view of........................ 50

structure of, figure showing........... 57

Brownsville, quarries near............ 117, 118

Bruce, A. E., \& Sons, quarry of........... 58

Bruce quarry, description of.............. 58-59

strain in ......................... 17

Buck Pond, quarries near...... 93, 95, 103, 104-105

Buffalo Ilil!, geology at................. 14 quarries on ........................ 27-29

Bugbee, Alexander \& Packer, prospect of.... 33-34

Burke Granite Co., quarry of............... 32

Burke quarry, description of............. 32-33

$$
\text { C. }
$$

Cabot Town, quarries in ................ $\quad 90$

Calais Town, description of................ 90-91

geology of ........................ 14

granite of, composition of............. 11

quarries in . ....................... 91-93

Caledonia Co., granite of .............. 9, 27-42

Caledonia Quarry Co., quarry of........... 37

Canton quarry, description of . . . . . . . . $84-75$

strain in.............................. 17

figure showing.................. 18

Capital quarry, description of ............ $89-81$ 
Page.

Carlton \& Lake, quarry of ............... 29

Carson Brothers, quarry of. ............. 101

Carson quarry, description of............ 101

Center Pond, quariy near. ................ 33

Chase quarries, description of............ 104-105

Chrusthov, K. D., on orbicular granite..... 25

Clark, James, quarries of. ................ 108

Clark quarries, description of ............ 108

Classification, scheme of . ................ 119-121

Coarse grained, significance of........... 8

Cobble Hill, quarries near. . . . . . . . . . 47, 89

sheets on ........................ 53

Consolidated Marr \& Gordon quarry, description of.................... $78-79$

structure in, figure showing . . . . ..... 79

Consolidated Quarry Co., quarries of . . 78, 79, 80, 81

Constructional granites, list of ........... 120

Contact phenomena, occurrence of........ 20

Coons, A. T., on production of granites . . . 122-126 work of . . . . . . . . . . . 7

Couyellard quarry, description of......... 81

Craftsbury, nodules at.................. 25

Cross, Whitman, on Wells-Lamson granite... 76-77

D.

Daly, R. A, on Mount Ascutney geology .... 8 $12,14,15,116$

Day, W. C., on Barre granite........... 52 on Wells-Lamson quarry granite...... 77

Definitions, glossary of. .............. 130-133

Derby Town, geology in ................ 13 quarries in $\ldots \ldots \ldots \ldots \ldots \ldots \ldots \ldots \ldots \ldots, 45,46$

Dikes, age of . . . . . . . . . . . . . . . . 15,16

Distribution of quarries, extent of ........ 9-10 map showing.................... 10

Drenan, Brown \& Raycraft, quarries of..... • 102

Drenan quarries, description of........... 102 granite of....................... 95, 102

Duffee quarry, description of . .......... 71-72

Dummerston Town, granite of. .......... 105-106 granite of, composition of. . ........... 12 quarries in .................. 106-109 strain in

\section{E.}

Economic aspects, discussion of. $27-127$

Ellis, E. B., quarry of ................. 112

Ellis quarry, contact in ................ 20 description of . . . . ................ 112-114 granite of $\ldots \ldots \ldots \ldots \ldots \ldots \ldots \ldots \ldots .25$ structure in . . . . . . . . . . . . . . 25, 112-113

figure showing................. 112

Empire Granite and Quarrying Co., quarry of 84

Empire Granite Co.'s quarry, description of. . 84-85

Empire quarries, description of. ...... 60-61, 92-93 structure in, figure showing.......... 61

Eureka Granite Co., quarry of............ 92

Explosives, use of . . . . . . . . . . . . 126-127

\section{F.}

Farquharson, G. P., quarry of

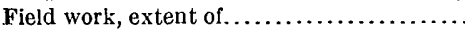

Fine grained, significance of.

Finlay, G. I., on Barre granite...... $8,18,21,47-49$

Fisher, L. C., quarry of................ 105

Fletcher, E. R., quarry of ............. 96
Page.

Fletcher quarry, description of. .......... 96-98 granite of $. \ldots \ldots \ldots \ldots \ldots \ldots \ldots \ldots \ldots \ldots . \quad 95$ sheeting in ................... 17,95,97 plate showing ................ 94 strain in......................... 17

Frazer quarry, delimonization in......... 26 description of ..................... 40 sheets in ...................... 35,40 Frosterus, B., on nodules............... 26 Fryatt \& Carr, prospect of.............. 104

G.

Geologic features, descriptions of ......... 16-26

Geologic history of quarries, outline of...... 16

Geologic relations, description of......... 13-15

Gibson quarry, description of........... . 36-37

Glossary of terms................... 130-133

Grain, differences in................. 8

Granite City Quarry Co., quarry of........ 63

Granite railroads. See Railroads.

Granites, characteristics of .............. 119

classification of ................... 119

production of.................... 122-126

value of ....................... 122

See also particular granites, quarries, etc.

Groton, quarries near................ 40,42

Groton Town, granite of, composition of... 12 map of ....................... 35 quarries in . . . . . . . . . . . . . . . 40-42 strain in ........................ 17-18

Grout quarry, description of............ 29-31

E.

Hardwick Granite Co., quarry of........ 27

Hardwick Town, geology in............ 14 quarries in . . . ................... 27-29

Hardwick white granite, description of . . . . 110-112

Hawes, G., on Craftsbury granite......... 25

Hinchey, Mrs. Margaret, quarry of........ 40

Hitchcock and Hager, map of............ 14 on nodular granite................. 25

Hornblende-augite, age of ............. 15 carving of, view of.................. 112 composition of....................... 11, 12

Hyland quarry, description of .......... 89

\section{I.}

Inclusions, nature of................ 18-20

Innes \& Cruikshank quarry, description of . . 80

Intrusions, time of ................ 15,16

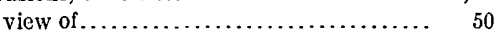

Italian quarry, description of ........... 37-38 sheets in ..................... 35,38

\section{J.}

Johannsen, Albert, work of............ 7

Jones Brothers \& Co., quarry of . . . ..... 85, 86

Jones Brothers Co., quarry of.............. 65

Jones Dark quarry, description of . . . . . . 85-86

Jones Light quarry, description of . . . . . . 65-67 structure in, figures showing......... 66,67 Jones Small Dark quarry, description of.... $\quad 86$ K.

Kearney Hill quarry, description of....... 31-32 Kearney. Hill Quarry Co., quarry of....... 31 
Kinnicutt, L. P., on Barre granite.......... $\quad 52$

Kirby Town, map of... quarries in.

30

L.

Lake Shore quarry, description of.

Lake Shore Quarry Co., quarry of .

Lambert, J. W., prospect of, description of .. $\quad 90$

Liberty Hill Granite Co., quarry of......... 115

Liberty Hill quarry, description of....... 115-116

Literature, list of ................... 127-129

Lyons (George E.) Co., quarry of.......... 106

\section{M.}

McCrae, Benzie \& Co., quarry of.

McDonald \& Cutter $\mathrm{Co}$ quarry, description

McIver \& Matheson, quarry of............ 81

McIver \& Matheson quarry, description of... 81-82

McLeod, J. H., quarry of................. 105

Mackville, quarries at................... 27

Manufacturers' quarry, description of....... 82

Manufacturers' Quarrying Co., quarry of.... 82

Marr \& Gordon quarry, description of...... 61-62

Medium grained, significance of........... 8

Memphremagog, Lake, quarries near....... 45,46

Memphremagog slate, occurrence of ....... 14-15

Merrill, G. P., work of .................. 7-8

Metamorphism, time of ................ 16

Mica schist. See Schist.

Miller, G. F., quarry of................... 101

Millstone Hill, quarries on and near...... 47, 57quarries near, map of ................. 48 sheets on............................ 52-53

Milne, Alexander, quarry of .............. 83

Milne quarry, description of............... 83-84

Milne \& Varnum, quarry of............... $\quad 59$

Milne \& Wiley quarry, description of...... $59-60$

Montpelier, quarries near............... 90,91

Monumental granites, carvings of, views of . . . . . . . list of ........................ 120-121

Morrison (D. A.) \& Co., quarry of.......... 37

Morrison quarry, description of ........... 37 granite of, inclusion in ............. 19-20,37 view of ........................ 50

Mower quarry, description of ............ 117-118 N.

Newark Town, map of. 30 quarries in ....................... $33-34$ Newport, quarry near................... 45 Newport Granite Co.'s quarry, description of. 45-46 Nichols Ledge, quarries at............ 93,95, 105 Nichols Ledge Carter quarry, description of.. 105

Nodules, occurrence of. ................. 25-26 view of ............................. 50

Norcross quarry, description of .......... 118-119 North Concord, quarries near.......... 29,31,32 Northern Granite Co., quarries of.......... 27

\section{0.}

O'Herin (Robert) \& Co., quarry of......... 75 O'Herin quarry, description of............. 75 Orange Co., granite of. ................ 9,42-44 Orbicular granite, description of ........... 25-26 view of

Orleans Co., granite of................ 9,45-47
P.

Page.

Parmenter, W. H., quarry of.............. $\quad 46$

Parmenter quarry, description of........... 46

Patch \& Co., quarry of .................. 91

Patch quarry, description of............... 91

Pegmatite, dikes of ....................... 13 intrusion of ...................... 16

Perkins, G. H., on Vermont granites........ 27, 43 work of........................ 7

Petrography of granites, outline of......... 11-12

Pine Mountain, quarry on............... 42

Pirie, J. K., quarry of .................. 87

Pirie quarry, description of.............. $\quad 87$ structure of, figure showing............ 87

Production, statistics of . ............... 122-126

Pruneau \& Co., quarry of................ 78

Pruneau quarry, description of........... 78

\section{Q.}

Quarries, geologic features in .............. 16-26 See also particular quarries.

Quarrying, use of explosives in.......... 126-127

Quartz monzonite, carving of, view of...... 112 composition of ..................... 11-12

R.

Railroads, importance of ................ 27 maps showing.................. 28,48, 110

Randolph Town, granite in, composition of.. 12 quarries in ........................ 43-44

Richardson, C. H., map of............ 9, 14-15

Ricker, I. M., quarry of ................ 42

Ricker quarry, description of............. 42-43

Robeson Mountain, contact at............ 24,93 geology at......................... 13 quarries on ................... 93,96-102, 105 sheeting on, view of ................. 94 structure on ....................... 17

Rochester, granite of, description of.. 11-12,115-116

Rosa quarry, description of................ 38-40 sheets in ......................... 35-39

Ryegate Granite Works, quarry of......... 36

Ryegate Town, geology of................ 35-36 granite of........................... 35 inclusions in ..................... 19,35 map of.......................... 35 quarries in........................... $30-40$

strain in....................... 18

topography of ...................... 34

S.

Sanguinetti, Joseph, quarry of........... 72 Sanguinetti quarry, description of.......... 72 Schaller, W. T., work of................ 7, $34,39,44,51-52,61,65,69,97,106,111,116$

Schist, distribution of ................... 13-15 inclusions of ........................ 18-20

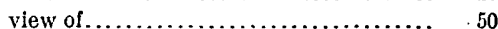

Scientific aspects, discussion of............. $9-26$ Scope of report......................... 7 Scott, C. N., quarry of................... 68

Sculpture, use of granites for............. 119 views of ....................... $68,94,112$

Sheeting, view of ...................... 68

Sheets, delimonization of ................. 26

Sheet structure, double, description of...... $\quad 17$

Slate, distribution of . ................... 13-15

Smith (E. L.) \& Co., quarries of........ $(99,71,72$ 
Smith Lower quarry, description of......... $\quad \begin{array}{r}72 \\ \text { Page. }\end{array}$

Smith Upper quarry, description of. ...... 69-71 structure of, figure showing............ 70

South Ryegate, granite of, composition of.... 11, 12 granite of, view of ................... 50 quarries near..................... $36-40,42$

Stephen \& Gerrard, quarry of............. 64

Stephen \& Gerrard quarry, description of.... 64-65 structure in, figure showing........... 65

Strain, compressive, occurrence and effects of . 17-18

Stratton quarry, description of............ $\quad 85$

Stratton (George) Quarry Co., quarry of..... $\quad 85$

Syenite. See Fornblende-augite granite..... 14

\section{T.}

Technology, glossary of................ 130-133

Topsham Town, granite of, composition of.. 12 map of ............................ 35 quarries in. . ....................... $42-43$

Trade names of granites, list of .......... 120-121

Tupper (W. S.) \& Co., quarry of........... 38

Tupper quarry, description of.............. 38 strain in.

$$
\text { v. }
$$

Values of granites, data on..................

Vermont Grey Granite Co., quarry of........ 38

Vershire schist, occurrence of............. 14

Vogt, J. H. L., on formation of apatite...... 23

W.

Waits River limestone, occurrence of....... 14

Walker $\&$ Sons, quarry of ................ 76

Walker quarry, description of............. 76

Washington Co., granite of ............ 9, 47-105

Webber Granite Co., quarries of........... 103

Webber quarries, contact at............... 24 description of . . . . . . . . . . . . . . . . . 103-104 granite of........................ 95, 103
Page.

Wells-Lamson quarry, description of ........ 70-78 granite of, analysis of ................ 77 strain in........................... 17

Wells-Lamson quarry Co., quarry of ....... $\quad 76$

Wetmore \& Morse Granite Co., quarry of.... 68

Wetmore \& Morse quarry, description of. ... $\quad 68$

Wheaton quarry, description of. ......... 87-88

Wildbur Brothers \& Bessey, quarry of...... $\quad 88$

Wildbur quarry, description of........... 88-89

Williamstown Town, quarries in ........... 42

Windham Co., granite of .............. 10, 105-109

Windsor Co., geology of................. 109-112

granite of......................... 9-10

map of $\ldots \ldots \ldots \ldots \ldots \ldots \ldots \ldots \ldots \ldots, 110$

quarries of . . . . . . . . . . . . . . . . . 112,119

topography of .................... 109-110

Windsor granite, description of.......... 116-117

Windsor Green Granite Co., quarry of...... 118

Windsor Town, geology of.............. 116-117 quarries in....................... 117-119 topography of . .................... 116

Woodbury Co.'s quarry, description of. ... 114-115

Woodbury granite, carving of, view of...... 94 description of ................... 11,94-95

Woodbury Granite Co., quarries of........ 98, 114 quarries of, description of ............ 98-111 sheets in ......................... 95 structure in, figure showing.......... 100

Woodbury Town, contact in.............. 24-25 geology in.................. 13, 14,93-96 quarries in . ...................... 96-105 geology of . ................... 95-96 map showing.................... 28 strain in......................... 17 topography of ..................... 93

Woodbury \& Bailey, quarry of............ 62

Woodbury Granite Co.'s quarries, sheeting in $1 \overrightarrow{7}$ strain in.......................... $\quad \vec{i}$

Woodbury Lower quarry, granite of........ 